DANIEL BERNARDES DE OLIVEIRA BABINSKI

\title{
O DiREITO À EDUCAÇÃO BÁSICA NO ÂMBITO DO MERCOSUL - PROTEÇÃO NORMATIVA NOS PLANOS CONSTITUCIONAL, INTERNACIONAL E REGIONAL
}

DisSERTAÇÃO DE MESTRADO

ORIENTADORA:

PROF ${ }^{\mathrm{a}}$. DR. NINA BEATRIZ STOCCO RANIERI

FACUldade de Direito da Universidade de São PaUlo

SÃo PAULO 2010 
DANIEL BERNARDES DE OLIVEIRA BABINSKI

\section{O DiREITO À EDUCAÇÃO BÁSICA NO ÂMBITO DO MERCOSUL - PROTEÇÃO NORMATIVA NOS PLANOS CONSTITUCIONAL, INTERNACIONAL E} REGIONAL

DISSERTAÇÃO APRESENTADA À FACULDADE DE DIREITO DA USP, COMO REQUISITO PARCIAL PARA A OBTENÇÃO DO TÍTULO DE MESTRE EM DIREITO

ÁREA DE CONCENTRAÇÃO: DIREITO DO ESTADO ORIENTADORA: PROF ${ }^{a}$ DR $^{a}$ NINA BEATRIZ STOCCO RANIERI

FACUldade DE DiReito da Universidade de SÃo PaUlo

SÃo PAULO 
"Fazemos isto não apenas pela atual geração, mas por todas as gerações futuras. Não existe tarefa mais nobre do que dar a todas as crianças um futuro melhor." Declaração Mundial sobre a Sobrevivência, a Proteção e o Desenvolvimento da Criança (Nova Iorque, 30 de setembro de 1990)

"Ensina a criança no caminho em que deve andar e nem quando for velho se desviará dele". Provérbios 22, versículo 06. 


\section{AgradeCIMENTOS}

À minha mãe e professora Mary Elizabeth, pelo infindável e inefável amor.

À Professora Nina Ranieri, por me ensinar a cultivar o apreço e respeito ao direito à educação. Agradeço-lhe pela confiança e pela oportunidade.

A minha irmã Paula, por não se acovardar e mostrar que o impossível é possível.

Ao meu companheiro Daniel Wang, pelo contínuo exemplo de vida.

Ao meu querido Jean, companheiro e consolador.

À inestimável ajuda de Mariana Chaimovich, pelas idéias, infindável paciência e carinho.

A Bianca Soares, pela perseverança e compromisso.

Aos queridos do GVlaw, Handemba Mutana, Daniel Sales, João Firmino, Fabia Veçoso, Douglas Leite, Monica Pinhanez, Juliana Palma e Camila Perruso.

Aos antigos amigos Celio Azuma, Guilherme Pissaia e Leandro Marziliak.

Aos novos amigos Igor Navarro e Diego Vieira.

A todos os monitorandos da disciplina de Teoria Geral do Estado, pelo incentivo. 


\section{RESUMO}

O direito à educação básica conforma direito de tipo especial, visto que sua proteção é condição necessária para o usufruto de todos os outros direitos fundamentais. A presente dissertação de mestrado procura analisar a extensão da proteção normativa concedida a esse direito nos Estados-Partes do MERCOSUL. Tal análise será feita mediante uma pesquisa conduzida em três níveis distintos, nomeadamente, o plano constitucional, internacional e o regional. Em virtude de sua natureza individual e coletiva, fundamental e humana, o direito à educação básica é tutelado nestes três planos, ensejando uma necessária apreciação de suas interelações. Desta forma, o presente estudo analisa não apenas as normas constitucionais em matéria educacional, mas se amplia para toda a produção de documentos internacionais tratados e declarações - que tutelam o direito à educação básica. Por último, analisaremos o papel da educação no fenômeno da integração mercosulina, concluindo que é inegável que a estruturação do Setor Educacional do MERCOSUL ainda não foi capaz de incrementar a proteção normativa do direito à educação básica, resumindo suas atividades à compilação de informações estatísticas, reconhecimento de diplomas e títulos de grau entre os EstadosPartes e fomento de uma mentalidade favorável à integração. Infelizmente a ousadia das declarações internacionais contrasta com a timidez das atividades mercosulinas.

PAlavras-ChAVe: Educação - Educação Básica - Direito à Educação - MERCOSUL Tratados Internacionais de Direito à Educação Básica 


\begin{abstract}
The right to basic education conforms a special right, given that its protection is a necessary condition for the enjoyment of all other fundamental rights. This dissertation aims to analyze the extent of juridical protection granted to the right to basic education in the Member States of MERCOSUR. This analysis shall be done through a survey conducted at three different levels, namely, the constitutional level, international and regional. Because of their juridical nature as individual and collective, as fundamental and human, the right to basic education is protected in these three planes, allowing for a necessary appreciation of their interrelations. Thus, this study is not reduced to the educational provisions located on the constitutional plain, and contemplates the entire production of international documents - treaties and declarations - which protect the right to basic education. Finally, we analyze the role of education in the phenomenon of integration conducted in the MERCOSUR, concluding that it is undeniable that the structuring of the Educational Sector of MERCOSUR has not yet been able to increase the legislative protection of the right to basic education, summarizing its activities to the compilation of statistical information, recognition of degree certifications among States Parties, and promoting a spirit of integration. Unfortunately, the boldness of the international declarations contrasts with the timidity of the regional activities.
\end{abstract}

Palavras-Chave: Education - Basic Education - Right to Education - MERCOSUL International Treaties on the Right to Basic Education 


\section{SUMÁRIO}

$\begin{array}{ll}\text { Abreviaturas } & 09\end{array}$

$\begin{array}{ll}\text { Introdução } & 11\end{array}$

Capítulo 1 - O Direito à Educação Básica no Plano Constitucional 19

1.1 - Constitucionalização dos Direitos Fundamentais 19

1.1.1 Direito à Educação nas Primeiras Constituições Mercosulinas 25

1.2 - Breve Análise Acerca das Constituições Vigentes dos Estados- 26

1.3 - Normas Constitucionais de Direito à Educação Básica no MERCOSUL

1.3.1 Argentina 29

1.3.2 Brasil 31

$\begin{array}{ll}\text { 1.3.3 Paraguai } & 37\end{array}$

1.3.3 Uruguai 39

$\begin{array}{ll}\text { 1.3.3 Quadros Comparativos } & 40\end{array}$

1.4 - Estrutura dos Sistemas de Ensino Mercosulinos 43

1.4.1 Argentina 44

$\begin{array}{ll}\text { 1.4.2 Brasil } & 48\end{array}$

1.4.3 Paraguai 51

1.4.3 Uruguai $\quad 56$

1.4.3 Quadro Comparativo 61

1.5 - Esquema “D+3A" no Plano Constitucional 62

Capítulo 2 - O Direito à Educação Básica no Plano Internacional 66

2.1 - A Internacionalização dos Direitos Humanos 66

2.1.1 A Educação nas Primeiras Declarações Internacionais 71

$\begin{array}{ll}2.2 \text { - Tratados Internacionais } & 73\end{array}$

2.2.1 Conceito de Tratado Internacional 73 
2.2.2 Nascimento, Vida e Morte dos Tratados Internacionais

2.3 - Integração dos Tratados Internacionais ao Direito Interno dos Estados-Membros do MERCOSUL

1.4.1 Argentina

1.4.2 Brasil

1.4.3 Paraguai 92

1.4.3 Uruguai 94

1.4.3 Quadro Comparativo 97

2.4 - Documentos Internacionais sobre o Direito à Educação Básica 99

2.4.1 Principais Tratados Internacionais Referentes à Educação Básica 100

2.4.2 A Proteção ao Direito à Educação Básica pela Via da Especificação dos Direitos Humanos

2.4.3 A Ousadia das Declarações Mundiais

2.5 - Esquema "D+3A" no Plano Internacional

3.1.2 A Consolidação Institucional do MERCOSUL

3.3 - Setor Educacional do MERCOSUL - A Educação no Processo de Integração

3.3.1 Estrutura Orgânica

3.3.2 Financiamento do SEM

3.3.3 Evolução das Atividades do SEM 


\section{ABREVIATURAS}

ADCT - Ato das Disposições Constitucionais Transitórias

ALADI - Associação Latino-Americana de Integração

ALALC - Associação Latino-Americana de Livre-Comércio

ANEP - Administração Nacional de Educação Pública

CA - Constituição Argentina

CADH - Convenção Americana de Direitos Humanos

CAFEM - Comitê Acessor do Fundo Educativo do Mercosul

CB - Constituição Brasileira

CCM - Comissão de Comércio do Mercosul

CCR - Comitê Coordenador Regional

CDC - Convenção sobre os Direitos da Criança

CEPAL - Comissão Econômica para a América Latina

CIJ - Corte Internacional de Justiça

CINE - Classificação Internacional Normalizada de Educação

CMC - Conselho de Mercado Comum

CPC - Comissão Parlamentar Conjunta

CRCA - Comissões Regionais Coordenadoras de Área

CRC-EB - Comissão Regional Coordenadora de Educação Básica

CRC-ES - Comissão Regional Coordenadora de Ensino Superior

CRC-ET - Comissão Regional Coordenadora de Educação Tecnológica

CVDT - Convenção de Viena sobre o Direito dos Tratados

CU - Constituição Uruguaia

$\mathrm{CP}$ - Constituição Paraguaia

DADDH - Declaração Americana dos Direitos e Deveres do Homem

DIP - Direito Internacional Público

DUDH - Declaração Universal dos Direitos Humanos

FCES - Foro Consultivo Econômico-Social

FEM - Fundo de Financiamento do Setor Educacional do MERCOSUL

FUNDEB - Fundo de Manutenção e Desenvolvimento da Educação Básica e dos Profissionais da Educação 
FUNDEF - Fundo de Manutenção e Desenvolvimento do Ensino Fundamental e do Magistério

GATT - Acordo Geral de Tarifas e Comércio

GGP - Grupos Gestores de Projeto

GMC - Grupo Mercado Comum

ISCED - International Standard Classification of Education

LDB - Lei de Diretrizes e Bases da Educação

MERCOSUL - Mercado Comum do Sul

MEC - Ministério da Educação e Cultura

OEA - Organização dos Estados Americanos

OEI - Organização dos Estados Inter-americanos

ONU - Organização das Nações Unidas

PIDESC - Pacto Internacional de Desenvolvimento Econômico, Social e Cultural

PNE - Plano Nacional de Educação

POP - Protocolo de Ouro Preto

PSS - Protocolo Opcional à Convenção Americana de Direitos Humanos (Protocolo San

Salvador)

RME - Reunião dos Ministros da Educação

SAM - Secretaria Administrativa do Mercosul

SEM - Setor Educacional do Mercosul

SIC - Sistema de Informação e Comunicação

STF - Supremo Tribunal Federal

TA - Tratado de Assunção

UNICEF - Fundo Internacional de Emergência das Nações Unidas para as Crianças 


\section{INTRODUÇÃO}

O estudo do direito à educação básica no âmbito dos Países-Membros efetivos do MERCOSUL ${ }^{1}$ se justifica na medida em que se propõe analisar a extensão da proteção normativa constitucional, internacional e regional, com vistas a melhor compreender o alcance desta proteção, resultado jurídico de duas lógicas distintas e complementares: a internacionalização dos direitos humanos e a constitucionalização dos direitos fundamentais. ${ }^{2}$

Neste sentido, há de se notar que o título da dissertação propositadamente apresenta uma ambigüidade. Ao escolhermos discorrer acerca do direito à educação básica no âmbito do Mercado Comum do Sul - MERCOSUL, permitimo-nos, primeiramente, conhecer das normas constitucionais dos Estados-Membros, valendo-nos de uma perspectiva comparada, objetivando conhecer a real extensão da proteção consagrada no plano constitucional.

Contudo, o título também nos oferece proceder ao estudo das normas internacionais decorrentes de tratados internacionais de direitos humanos que versam sobre a educação básica, bem como a forma de sua integração ao ordenamento interno destes Estados, possibilitando-nos cotejar os dois planos jurídicos distintos.

Um terceiro momento também se insere no contexto de nosso título: a análise da normativa emitida pelo seu Setor Educacional do MERCOSUL, bem como as atividades empreendidas pelo bloco regional no contexto da educação básica. Acreditamos, assim, termos atendido ao desafio de conhecer do direito à educação básica nos três níveis normativos distintos.

\footnotetext{
${ }^{1}$ Acerca dos países estudados, é preciso esclarecer que o corte metodológico privilegiou apenas os países considerados como membros efetivos do Mercado Comum do Sul - MERCOSUL, portanto, Argentina, Brasil, Paraguai e Uruguai. Desta forma, os países em vias de acesso, como a Bolívia e a Venezuela, ou ainda os Estados associados ao bloco regional, foram excluídos da análise. Contudo, todos estes parceiros econômicos recebem atenção especial.

${ }^{2}$ À guisa de distinção, Ingo Sarlet defende que os direitos humanos, num primeiro momento, foram identificados a abstrações ou ideais internacionalistas, sem uma pretensão de eficácia. No entanto, o desenvolvimento da temática dos Direitos Humanos no Direito Internacional Público, contribuiu para a identificação dos direitos humanos como normas de Direito Internacional, enquanto os direitos fundamentais encontravam-se sedimentados nos ordenamentos jurídicos internos dos Estados, $C f$. SARLET, Ingo Wolfgang. A Eficácia dos Direitos Fundamentais. Porto Alegre: Livraria do Advogado, 1998. p. 34.
} 
O direito à educação, por sua vez, é de difícil definição. A dificuldade de sua conceituação é exemplificada, com extrema maestria, por Nina Ranieri, ao identificar o direito à educação como

\begin{abstract}
"direito fundamental social, é direito individual e também direito coletivo. Os seus titulares e os seus sujeitos passivos, são, simultaneamente, uma coisa e outra. Comporta obrigações de fazer e não fazer, por parte de titulares e sujeitos passivos, que não exaurem e exigem diferentes atendimentos, algumas vezes sob reserva do possível. Seu regime jurídico, portanto, é complexo: envolve diferentes poderes e capacidades de exercício dos direitos fundamentais $\left(\mathrm{CF}\right.$, art. $5^{\circ}$, parágrafo $1^{\circ}$; art. 60 , parágrafo $4^{\circ}$, IV), mesmo dependendo de prestações materiais e recursos financeiros".
\end{abstract}

Prossegue ainda a autora, reconhecendo implicitamente a unidade e indivisibilidade dos direitos humanos, na medida em que aproxima o direito à educação da idéia de um “overarching right", valendo-se de Robert Alexy:

\begin{abstract}
"Consiste tanto em direito individual como em direito coletivo, revelando-se, ainda, como uma habilitação de caráter instrumental. Estas dimensões, inter-relacionadas, permitem a adultos e crianças marginalizados a integração na comunidade pela promoção da emancipação feminina e proteção das crianças contra a exploração de seu trabalho ou a exploração sexual. Ademais, possibilita a difusão da democracia, dos direitos humanos e da proteção do meio ambiente, valores cruciais no mundo contemporâneo" 4 .
\end{abstract}

Contudo, a proteção do direito à educação básica somente pode ter início com a tentativa de definição do objeto da tutela jurídica. Nina Ranieri já apresentou a dificuldade encontrada em tal intento, vez que o termo "educação" indubitavelmente comporta palavra plurívoca, na verdade. A autora demonstra, por meio de várias passagens legislativas, a utilização das palavras "ensino" e "educação" sinônimas, por exemplo. Conclui ainda que

\begin{abstract}
"Nem a doutrina nem a jurisprudência, contudo, têm cogitado dessa problemática, que aparentemente, não tem interferido na interpretação das normas constitucionais referidas ao direito à educação como se pode notar na grande maioria dos julgados do
\end{abstract}

\footnotetext{
${ }^{3}$ RANIERI, Nina. O Estado Democrático de Direito e O Sentido da Exigência de Preparo da Pessoa para o Exercício da Cidadania, pela Via da Educação. Tese de Livre Docência em Direito do Estado: USP, 2009. p. 286.

4 RANIERI, Nina Beatriz Stocco; ARNENSEN, Erik Saddi. "O Supremo Tribunal Federal e o Direito Internacional à Educação: a Promoção Indireta dos Princípios e Normas Internacionais”. In: AMARAL JÚNIOR, Alberto do; JUBILUT, Liliana Lyra. Jubilut, O STF e o Direito Internacional dos Direitos Humanos. São Paulo, Quartier Latin, 2009. p. 636.
} 
Supremo Tribunal Federal, nos quais a educação é tomada mais pelas suas finalidades que pelo seu conteúdo (...)",

A fim de providenciar critérios objetivos de comparação e estruturação dos mais diferentes sistemas de ensino, justificam-se os esforços consagrados na criação do International Standard Classification of Education (ISCED, Classificação Internacional Normalizada da Educação - CINE, em português), publicado no âmbito da UNESCO em 1997, em razão de uma revisão de documento anterior, introduzido em 1976. O mencionado documento fornece uma definição para o termo "educação", a qual será adotada como linha mestra para a condução deste trabalho:

\footnotetext{
“A todos os efeitos da CINE, o temo 'educação' se toma na acepção que compreende todas as atividades voluntárias e sistemáticas destinadas a satisfazer as necessidades de aprendizagem, incluindo o que em alguns países se denomina atividades culturais ou de formação. Seja qual for a denominação adotada, a educação supõe neste caso uma comunicação organizada e continuada, destinada a suscitar a aprendizagem", .
}

Antes de procedermos ao nosso estudo, porém, é fundamental realizarmos previamente as seguintes questões: o que é educação básica? É possível identificar algum denominador comum entre sistemas de ensino completamente distintos? Ao encetarmos o presente trabalho, deparamo-nos imediatamente com este problema. Enquanto a legislação brasileira, define educação básica

Novamente a resposta se encontra no Cine 97, responsável por permitir a comparabilidade a partir de indicadores educacionais objetivos e subjetivos, como a idade teórica oficial de ingresso ao níve de ensino e a complexidade dos programas ministrados em cada ciclo. Reproduzimos, a seguir, tabela que contempla as linhas gerais de cada nível de ensino definido no mencionado documento:

\footnotetext{
${ }^{5}$ RANIERI, Nina. O Estado Democrático, op. cit.. p. 278.

${ }^{6}$ Trata-se de tradução livre para o português do documento que se encontra disponível em UNESCO. Clasificación Internacional Normalizada de Ensino. Paris: UNESCO, 2006. p. 09. Ressaltamos que se encontra disponível eletronicamente em: http://www.uis.unesco.org/TEMPLATE/pdf/isced/ISCED_E.pdf. Acesso em 23 de janeiro de 2010.
} 


\section{Q.1 - Classificação CINE $97^{7}$}

\begin{tabular}{|c|c|}
\hline Nível & Descrição \\
\hline $\begin{array}{c}\text { Cine } 00 \\
\text { Educação Pré-Primária }\end{array}$ & $\begin{array}{l}\text { Período de atividades sistemáticas anteriores à obrigatoriedade do } \\
\text { ensino. A idade teórica corresponde ao intervalo entre } 03 \text { e a idade } \\
\text { de ingresso no nível posterior. Possui duração mínima anual de } 200 \\
\text { horas. }\end{array}$ \\
\hline $\begin{array}{c}\text { Cine } 01 \\
\text { Educação Primária ou Primeira Etapa } \\
\text { da Educação Básica }\end{array}$ & $\begin{array}{l}\text { Objetiva fornecer uma sólida base de leitura, escrita e aritmética. } \\
\text { Geralmente coincide com o início da obrigatoriedade do ensino e a } \\
\text { primeira etapa da educação básica. Destina-se a crianças entre } 06 \text { e } \\
\qquad 11 \text { anos de idade. }\end{array}$ \\
\hline $\begin{array}{c}\text { Cine } 02 \\
\text { Primeiro Ciclo do Ensino Secundário } \\
\text { ou Segunda Etapa da Educação Básica }\end{array}$ & $\begin{array}{l}\text { Inclusão da aprendizagem por disciplinas, vez que os alunos já } \\
\text { dominam os conceitos de aritmética e linguagem. Normalmente } \\
\text { coincide com o fim da obrigatoriedade, ao atender crianças entre } \\
12 \text { e } 14 \text { anos. }\end{array}$ \\
\hline $\begin{array}{c}\text { Cine } 03 \\
\text { Segundo Ciclo da Educação Secundária }\end{array}$ & $\begin{array}{l}\text { Usualmente posterior à educação obrigatória, é constituída por } \\
\text { programas com maior especialização da aprendizagem, professores } \\
\text { mais qualificados. Usualmente atende crianças entre os } 15 \text { e } 16 \\
\text { anos. }\end{array}$ \\
\hline $\begin{array}{c}\text { Cine } 04 \\
\text { Educação Pós-Secundária Não- } \\
\text { Terciária }\end{array}$ & $\begin{array}{l}\text { Procura ampliar os conhecimentos adquiridos nos níveis anteriores. } \\
\text { Há clara vocação para uma educação técnica, insuficiente para } \\
\text { permitir o acesso à educação terciária. }\end{array}$ \\
\hline $\begin{array}{l}\text { Cine } 05 \\
\text { Primeiro Ciclo da Educação Terciária }\end{array}$ & $\begin{array}{l}\text { Caracterizado por programas de formação teórica avançada ou } \\
\text { dedicação ao desenvolvimento de competências para o mercado de } \\
\text { trabalho. Garante acesso ao nível mais alto de educação. }\end{array}$ \\
\hline $\begin{array}{c}\text { Cine } 06 \\
\text { Segundo Ciclo da Educação Terciária }\end{array}$ & $\begin{array}{l}\text { Voltado aos estudos avançados, os quais por meio de pesquisa } \\
\text { original concedem o grau de doutor }\end{array}$ \\
\hline
\end{tabular}

\footnotetext{
${ }^{7}$ Este quadro pode ser consultado em ANASTASIA, Fatima et alli. "Redemocratização, Integração Regional e a Trajetória do Setor Educacional MERCOSUL". In: MERCOSUL. Estudo Analítico-Comparativo do MERCOSUL (2001-2005). Brasília: INEP, 2008. p. 40.
} 
Cumpre salientar que habitualmente o Setor Educacional do MERCOSUL identifica apenas três níves de ensino. Denomina de ensino básico o nível correspondete ao Cine 01 e 02, secundário ao Cine 03 e superior aos níveis 05 e $06{ }^{8}$

Contudo, empreenderemos um esforço por manter a classificação internacional proposta pela UNESCO, de forma a contemplar a educação básica dentro do período entre os Cines 01 e 04. Assim, por educação básica, entendemos excluída a educação pré-primária e a educação superior, esta entendida como englobando os níveis Cines 05 e Cine $06 .{ }^{9}$

Ao tratarmos dos documentos internacionais de educação básica, quando for possível a clara identificação dos níveis de ensino mencionados, procederemos à sua classificação, utilizando a nomenclatura retromencionada. Todavia, alguns diplomas internacionais não permitem precisa identificação, usualmente por empregarem - propositadamente, talvez expressões demasiadamente vagas, como "níveis elementares de ensino" ou ainda "primeiros níveis de ensino". É preciso reconhecer, contudo, que essas imprecisões não se encontram nos textos internacionais recentes, os quais já utilizam a classsificação internacional esposada.

\section{III}

A metodologia empregada para conhecer e classificar o conteúdo do direito à educação básica nos planos constitucional e internacional foi apresentada por Katarina Tomasevski, com a finalidade precípua de estruturar as obrigações jurídicas dos Estados no que tange o direito à educação. ${ }^{10}$ Esta mesma classificação foi empregada por Nina Ranieri, em seu mais recente trabalho, a propósito de analisar os conteúdos jurídicos do direito à educação na Constituição Brasileira de $1988 .^{11}$

\footnotetext{
${ }^{8}$ ANASTASIA, Fatima et alli. op. cit. p. 30.

${ }^{9}$ Por educação superior, cumpre mencionar que Nina Ranieri apresenta divergências doutrinárias sobre sua definição: “de acordo com o Dictionnaire Actuel de l'Éducation (Legendre, 1993), ensino superior designa todo tipo de educação dispensada em instituições pós-secundárias permitindo, ao final dos estudos, a obtenção de grau, diploma ou certificado. No Dictionnary of Education (Good, 1973), a educação superior é definida como a instrução oferecida a pessoas de considerável maturidade intelectual, previamente preparadas em escola secundária”, Cf. RANIERI, Nina B. S. Educação Superior, Direito e Estado na Lei de Diretrizes e Bases (lei n. 9394/96). São Paulo: EDUSP/FAPESP, 2000. p. 169, nota 32.

${ }^{10}$ TOMASEVSKI, Katarina. Human Rights Obligations: making education available, accessible, acceptable and adaptable. Gotemburgo: Novum Grafiska AB, 2001.

${ }^{11}$ RANIERI, Nina. O Estado Democrático de Direito e O Sentido da Exigência de Preparo da Pessoa para o Exercício da Cidadania, pela Via da Educação. op. cit. p. 317-320.
} 
A respeito da classificação dos conteúdos jurídicos, Tomasevski aduz que a estrutura básica das obrigações governamentais decorre das garantias expressas do direito educacional, presentes tanto em tratados internacionais de direitos humanos e constituições nacionais. ${ }^{12}$ Possui, na verdade, uma tríplice finalidade: "dar mais publicidade ao conteúdo do direito para titulares e sujeitos passivos, facilitar a identificação de prioridades em sua implementação do direito à educação, permitir a identificação de omissões, violações ou tratamento negligente por parte dos responsáveis". ${ }^{13}$

A metodologia, intitulada 4-A Scheme ou Esquema $D+3 A^{14}$, oferece a categorização dos conteúdos do direito à educação em quatro qualidades, estruturadas em torno de uma educação disponível, acessível, aceitável e adaptável.

Pela vertente da Disponibilidade, compreende-se duas obrigações governamentais distintas, de acordo com a expressão do direito à educação. Ou seja, entendido enquanto direito civil e político, consubstanciado na liberdade de ensino privado, e como direito social e econômico, ao requerer o seu financiamento pelas instituições educacionais oficiais, ou ainda, pela transferência de recursos ao setor privado. ${ }^{15}$ Falamos aqui também na normatização da atividade profissional na educação, visando a assegurar o mínimo de dignidade na prestação do serviço educacional, garantindo-se direitos aos professores e demais profissionais envolvidos. ${ }^{16}$

Na dimensão do Acesso encontramos a preocupação com a definição da obrigação compulsória e dos níveis educacionais em que se oferta a gratuidade da educação. Esclarece Nina Ranieri que a duração da obrigatoriedade geralmente abarca os níveis do Cine 01 e Cine 02 ao redor do mundo, ou seja, educandos entre quatro e treze anos de idade. ${ }^{17}$

A Admissibilidade encerra a questão da qualidade da educação, instando governos a prestarem um serviço educacional não apenas acessível e disponível, como também de

\footnotetext{
12 TOMASEVSKI, Katarina. op. cit. p. 13.

${ }^{13}$ RANIERI, Nina. op. cit. p. 320.

${ }^{14}$ Empregamos aqui a nomenclatura traduzida, em RANIERI, Nina. op. cit.p. 311-314.

${ }^{15}$ TOMASEVSKI, Katarina. op. cit. p. 15.

${ }^{16}$ RANIERI, Nina. op. cit. p. 312.

${ }^{17}$ Idem. loc. cit.
} 
qualidade. Nesta esfera, encontra-se também a preocupação por uma educação inclusiva e promotora da diversidade cultural, além de inibir a prática de castigos corporais. ${ }^{18}$

O prisma da Adequação cuida em assegurar o preparo do serviço educacional às necessidades especiais dos indivíduos, com vistas à aproximação do estabelecimento escolar e o aluno, como por exemplo, pessoas portadoras de necessidades especiais, jovens e adultos e refugiados. Usualmente este critério é atendido pelas diferentes modalidades de ensino que apresentamos ao longo do item anterior. ${ }^{19}$

Desta forma, ao final dos Capítulos 01 e 02, realizaremos a análise pertinente ao conteúdo do direito à educação vigente nos países do MERCOSUL, tanto por meio do texto constitucional, quanto pelos tratados internacionais de direitos humanos que cuidem da educação básica. Esperamos, assim, concluir, a análise acurada da extensão do direito à educação nestes países, antes de abordarmos as atividades empreendidas pelo bloco regional que os une.

\section{IV}

Ainda do ponto de vista metodológico, é preciso fazer algumas considerações. A metodologia empregada na dissertação de mestrado é fundamentalmente dogmatica-jurídica, abrangendo dois desdobramentos, quais sejam, analítico-descritivo e normativo. Ao longo de todo o trabalho foi feita uma escolha consciente pela utilização de fontes primárias normativas em detrimento das demais. Assim, há de se ressaltar a extensa pesquisa realizada junto aos órgãos mercosulinos, as constituições nacionais e os tratados internacionais. Quando necessária, há também a identificação de normas infraconstitucionais.

Ressalta-se, outrossim, a importância da metodologia do Direito Comparado na consecução deste trabalho, visto que a análise comparada não prescinde de cuidados com os planos semânticos e sintáticos, principalmente. Na medida do possível, buscar-se-á encontrar uma uniformidade semântica e sintática que permita o diálogo entre as diferentes definições e institutos presentes nos países estudados, sendo sempre respeitadas as peculiaridades dos

\footnotetext{
${ }^{18}$ TOMASEVSKI, Katarina. op. cit. p. 29.

${ }^{19}$ Idem. op. cit. p. 31.
} 
ordenamentos jurídicos estudados. Neste intento, encontramos valorosa ajuda em documentos internacionais confeccionados especialmente para este fim, como o já citado Cine 97.

Por fim, não se olvidará, ao longo da dissertação, a utilização de dados estatísticos colhidos junto à Setor Educativo do MERCOSUL, órgão comunitário responsável pela compilação dos dados educacionais oficiais fornecidos pelos Ministérios da Educação dos Estados-membros. Estes dados estão presentes na publicação comunitária anual intitulada "Indicadores Estadísticos del Sistema Educativo del MERCOSUL", projeto desenvolvido pelo Grupo Gestor do Projeto "Sistema de Indicadores del MERCOSUL Educativo", sob os auspícios do Setor Educativo do MERCOSUL (SEM) e Sistema de Informação e Comunicação do MERCOSUL Educativo (SIC). Estes dados ajudarão no conhecimento da situação fática da educação básica nos países do âmbito do MERCOSUL, permitindo-nos dialogar com a proteção normativa oferecida. 


\section{CAPÍTULO 1 - O DIREITO À EDUCAÇÃO BÁSICA NO PLANO INTERNO}

O objetivo precípuo deste capítulo é fornecer uma análise comparativa da extensão da proteção normativa voltada ao direito à educação básica nas constituições nacionais do MERCOSUL. Para tanto, passaremos brevemente pelo histórico da constitucionalização dos direitos fundamentais, procedendo à descrição e cotejo dos dispositivos constitucionais atualmente em vigor. Também serão mencionadas eventuais particularidades constitucionais de cada país, quando relevantes para a proteção do direito à educação básica. Outrossim, cuidaremos de apresentar a estrutura dos sistemas nacionais de ensino dos países sub studio, permitindo, assim, uma real identificação da educação básica no plano nacional. Neste intento, utilizaremos as fontes primárias infraconstitucionais necessárias ao estudo. Uma vez identificados os direitos referentes à educação básica e os ciclos nacionais da educação básica, teremos elementos suficientes para promover um estudo comparado da materialidade destes direitos, valendo-nos de metodologia classificatória desenvolvida por Katarina Tomasevski e empregada por Nina Ranieri.

\section{1 - Constitucionalização dos Direitos Fundamentais}

Conforme nos ensina Leslie Lipson, todos os agrupamentos humanos possuem como finalidade precípua o atendimento a determinada necessidade social, de forma que o Estado não poderia se furtar a estas finalidades, que podem ser diagnosticadas a partir do estudo das funções desempenhadas pelo próprio Estado. ${ }^{20}$ Desta feita, o Estado Moderno, entendido como "ordem jurídica soberana que tem por fim o bem comum de um povo situado em determinado território", 21 instrumentaliza-se no sentido de assegurar o atendimento das necessidades de uma coletividade, de forma que as funções e finalidades do Estado, portanto,

\footnotetext{
${ }^{20}$ LIPSON, Leslie. Os Grandes Problemas da Ciência Política. (trad. Thomaz Newlands Neto). $2^{\mathrm{a}}$. ed. Rio de Janeiro: Zahar, 1976. p. 84.

${ }^{21}$ DALLARI, Dalmo de Abreu. Elementos de Teoria Geral do Estado. 22a .ed. São Paulo: Saraiva, 2001. p. 118.
} 
correspondem aos ditames do momento histórico em que são formuladas, por meio das necessidades específicas eleitas como prioridades por cada povo em particular. $^{22}$

Contudo, a extensão destas funções e, conseqüentemente, dos poderes do Estado empregados no cumprimento destas funções, variaram ao longo da história em virtude das diferentes concepções de Estado desenvolvidas ao longo do século XIX e XX principalmente, ${ }^{23}$ de modo que as finalidades do Estado ganharam os mais diversos contornos e matizes. Todavia, é possível verificar, ao longo deste percurso, uma preocupação crescente com a positivação e garantia de certos direitos tidos como fundamentais.

De acordo com Maria Cristina Brito, o termo direitos fundamentais "apareceu na França de 1770, durante o movimento político e cultural que conduziu à Declaração dos Direitos Humanos e do Cidadão de 1789". ${ }^{24}$ É justamente a partir das Declarações de Direitos do último quartel do século XVIII que um rol especial de direitos ganha notoriedade e proeminência perante todo o ordenamento jurídico.

Estes direitos, de vocação universal, seriam identificados como "direitos de liberdade, inalienáveis, imprescritíveis e permanentes, inerentes ao homem, como ser humano e, portanto, anteriores à própria formação do Estado". ${ }^{25}$ Ademais, estariam consubstanciados no

\footnotetext{
${ }^{22}$ Ensina-nos Machado Paupério que "é sabido que o Estado não é um fim em si mesmo, mas apenas um meio para que os homens possam alcançar o seu fim próprio, através do melhoramento da vida humana", $C f$. PAUPÉRIO, Arthur Machado. O Conceito Polêmico de Soberania $2^{\mathrm{a}}$ ed. Rio de Janeiro: Forense, 1958. p. 192. ${ }^{23}$ Falamos aqui das diferentes concepções de Estado formuladas tanto por liberais - no sentido de um Estado de Segurança, mínimo por natureza - quanto por intervencionistas - defensores de uma atividade regulatória mais presente e firme do Estado. Mais a esse respeito em RANIERI, Nina Beatriz Stocco. Do Estado Liberal ao Estado Contemporâneo: notas sobre os processos de exaustão dos modelos políticos. Revista de Direito Constitucional e Internacional, São Paulo, v.9, n.36, pp. 135-161, jul./set., 2001.

${ }^{24}$ LIMA, Maria Cristina de B. A Educação como Direito Fundamental. Rio de Janeiro: Lumen Juris, 2003. p. 10 .

${ }^{25}$ Idem. op. cit. p. 15. Para José Afonso da Silva, as características que revestem os direitos fundamentais são: “a) historicidade - são históricos como qualquer outro direito. Nascem, modificam-se e desaparecem (...); b) inalienabilidade - são direitos intransferíveis, inegociáveis, porque não são de conteúdo econômico-patrimonial (...); c) imprescritibilidade - não se verificam requisitos que importem em sua prescrição. Vale dizer, nunca deixam de ser exigíveis (...); e d) irrenunciabilidade - não se renunciam direitos fundamentais. Alguns deles podem até não ser exercidos, pode-se deixar de exercê-los, mas não se admite sejam renunciados", SILVA, José Afonso da. Curso de Direito Constitucional Positivo. 10ª ed. São Paulo: Malheiros, 1995. pp. 179-180.
} 
corpo de uma Constituição, ${ }^{26}$ atuando como fundamento de legitimidade da ordem jurídica e balizador da atuação estatal. ${ }^{27}$

Nina Ranieri, por sua vez, lembra-nos que as palavras "constituição" e "constitucionalismo" não são termos neutros, pois, ao contrário, estão imbuídas de valores, concepções filosóficas e idéias políticas próprias do contexto em que vieram a lume. ${ }^{28} \mathrm{~A}$ noção de Constituição, tributária do contratualismo moderno, surge como grande trunfo do liberalismo político para conter os abusos do absolutismo, de forma que os revolucionários franceses enunciaram no artigo 16 da Declaração de 1789 que "toda sociedade na qual não está assegurada a garantia dos direitos nem determinada a separação de poderes, não tem Constituição". ${ }^{29}$ Neste sentido, pode-se afirmar que o constitucionalismo europeu do século XIX, entendido como a tentativa de se imprimir uma organização racional para a estrutura do Estado, refere-se à institucionalização do poder político por meio do direito positivo.

Objetivava-se, assim, impedir a caracterização do poder estatal como absoluto, balizando-o pelas normas constitucionais impostas pelo exercício do poder constituinte, responsável pela imposição de limites jurídicos e políticos à atuação do Estado. Nos dizeres de Luigi Ferrajoli:

\footnotetext{
"com a subordinação do próprio poder legislativo de maioria à lei constitucional e aos direitos fundamentais nela estabelecidos, o modelo do Estado de direito aperfeiçoa-se e completa-se no modelo do Estado constitucional de direito, e a soberania interna como 'potestas absoluta' (poder absoluto), já não existindo nenhum poder absoluto, mas sendo todos os poderes vinculados ao direito, se dissolve definitivamente". ${ }^{30}$
}

\footnotetext{
${ }^{26}$ Canotilho identifica os direitos fundamentais enquanto "direitos jurídico-positivamente vigentes numa ordem constitucional”, Cf. CANOTILHO, José Joaquim Gomes. Direito Constitucional e Teoria da Constituição. Lisboa: Almedina, 1999, p. 353.

27 A esse respeito, afirma Antonio Enrique Pérez: “em sua perspectiva histórica, a teoria dos direitos fundamentais procede da formulação doutrinária da noção de Estado de Direito, estando o seu embrião nas declarações de direitos do século XVIII, os quais germinaram por todos os princípios que formam o substrato ideológico do moderno regime constitucional", Cf. LUÑO, Antonio Enrique Pérez. Derechos Humanos, Estado de Derecho y Constitucíon. Madrid: Tecnos, 1999, p. 213.

${ }^{28}$ RANIERI, Nina. O Estado Democrático de Direito, op. cit. p. 91.

${ }^{29}$ FERREIRA FILHO, Manuel Gonçalves. Curso de Direito Constitucional. $27^{\mathrm{a}}$ ed. Saraiva: São Paulo, 2001. p. 7.

${ }^{30}$ FERRAJOLI, Luigi. A Soberania no Mundo Moderno. São Paulo: Martins Fontes, 2002. p. 33. Niccola Mateucci, por sua vez, reconhece na história moderna o triunfo do constitucionalismo sobre o Estado absoluto, afirmando que "soberania e constitucionalismo foram sempre entendidos como termos antitéticos; a vitória do segundo se deu com a elaboração das constituições escritas, cujas normas são hierarquicamente superiores às leis ordinárias e são tornadas eficazes por adequadas cortes judiciárias", Cf. MATEUCCI, Nicola; BOBBIO, Norberto; PASQUINO, Gianfranco. Dicionário de Política. Vol.2, 7ª Ed., Brasília: Universidade de Brasília, 1995. p. 1186.
} 
Contudo, como já afirmamos, as funções e finalidades do Estado correspondem a interpretações históricas. Desta feita, o modelo de Estado liberal neutro sofrerá duro golpe com a universalização do sufrágio e a conseqüente ampliação da participação política democrática. ${ }^{31}$ Neste contexto político e social de redefinição da atividade estatal surgem os direitos ditos econômicos e sociais.

Destarte, o constitucionalismo socioeconômico do século XX importou em novas obrigações ao Estado, a partir do reconhecimento de novos direitos tidos como fundamentais, entendidos, por grande parte da doutrina, como os direitos de segunda geração, isto é, direitos de titularidade individual e escopo social, que visam a garantir ao indivíduo a prestação estatal positiva de tutela. Falam-se, aqui, nos direitos econômicos, sociais e culturais, distintos, portanto, das primeiras liberdades fundamentais, derivadas dos direitos individuais tradicionais, que apenas previam esferas de não-atuação estatal. ${ }^{32}$

A segunda geração de direitos consagraria a promoção de uma igualdade material entre os tutelados, reivindicação que nasce das difíceis situações econômicas vivenciadas pela massa proletária nos fins do século XIX e início do século XX. Incapaz de franquear melhores condições de vida para as camadas mais baixas da população, a igualdade meramente formal - ou legal - dá espaço a direitos que busquem mitigar as desigualdades sócio-econômicas de uma dada sociedade. ${ }^{33} \mathrm{Na}$ visão de Flávia Piovesan, os direitos sociais são "autênticos e verdadeiros direitos fundamentais, acionáveis, exigíveis e demandam séria e

\footnotetext{
${ }^{31}$ Para um estudo mais aprofundado das conseqüências políticas deste fenômeno, bem como a apresentação de uma síntese da discussão doutrinária que se estabelece, consultar BERCOVICI, Gilberto. "As Possibilidades de uma Teoria do Estado". In: Revista da História das Ideias, Faculdade de Letras de Coimbra, vol. 26, 2005, pp.7-32.

32 Cumpre informar que a idéia de liberdades positivas e negativas (positive and negative liberty) nasce em 1958, em trabalho renomado de Isaiah Berlin, disponível em BERLIN, Isaiah. "Two Concepts of Liberty". In: BERLIN, Isaiah. Four Essays on Liberty. Oxford: Oxfor University, 1969. O referido autor arremata a sua distinção propondo duas perguntas: "The first of these political senses of freedom or liberty (I shall use both words to mean the same), which (following much precedent) I shall call the 'negative' sense, is involved in the answer to the question 'What is the area within which the subject - a person or group of persons - is or should be left to do or be what he is able to do or be, without interference by other persons?' The second, which I shall call the 'positive' sense, is involved in the answer to the question 'What, or who, is the source of control or interference that can determine someone to do, or be, this rather than that? The two questions are clearly different, even though the answers to them may overlap". Cf. Idem. op. cit. p. 42. No mesmo sentido, BOBBIO, Norberto. A Era dos Direitos (trad. Carlos Nelson Coutinho). Rio de Janeiro: Campus, 1992. p. 21. O autor ainda acrescenta que "todas as declarações recentes dos direitos do homem compreendem, além dos direitos individuais tradicionais, que consistem em liberdades, também os chamados direitos sociais, que consistem em poderes", Cf. Idem. loc. cit.

${ }^{33}$ SILVA, Roberta Soares da. "Artigos XXV e XXVI". In: BALERA, Wagner. Comentários à Declaração Universal dos Direitos do Homem. Brasília: Fortium, 2008. pp. 140-141.
} 
responsável observância. Por isso, devem ser reivindicados como direitos e não como caridade, generosidade ou compaixão."34

A doutrina ainda identificaria posteriormente uma terceira geração de direitos fundamentais, denominados costumeiramente de direitos de fraternidade ou solidariedade, de modo a encerrar a tríade revolucionária francesa. Manuel Gonçalves Ferreira Filho explica que esses direitos são identificados primeiramente no plano internacional, conhecendo posterior consagração constitucional, como o direito ao meio ambiente, direito à paz e direito ao desenvolvimento. ${ }^{35}$ No entanto, André Ramos Tavares define-os como

\begin{abstract}
“(...) direitos ou interesses metaindividuais. Fala-se em interesses metaindividuais ou transindividuais para significar aquela parcela de interesses que pertencem a um grupo razoavelmente externo de pessoas, que os titularizam e que possuem uma característica em comum, que as une, ainda que se trata de um laço de união extremamente débil". 36
\end{abstract}

De forma a arrematar a questão, o Ministro Marco Aurélio de Mello apresenta, em apertada e valiosa síntese, a categorização das três gerações de direitos fundamentais:

\begin{abstract}
"enquanto direitos de primeira geração (direitos civis e políticos) - que compreendem as liberdades clássicas, negativas ou formais - realçam o princípio da liberdade e os direitos de segunda geração (direitos econômicos, sociais e culturais) que se identificam com as liberdades positivas, reais ou concretas - acentuam o princípio de igualdade, os direitos de terceira geração, que materializam poderes de titularidade coletiva atribuídos genericamente a todas as formações sociais, consagram o princípio da solidariedade e constituem um momento importante no processo de desenvolvimento, expansão e reconhecimento dos direitos humanos, caracterizados enquanto valores fundamentais indisponíveis, pela nota de uma essencial inexauribilidade". 37
\end{abstract}

Entretanto, é importante mencionar que a categorização dos direitos fundamentais em gerações distintas não é unanimidade na doutrina, sofrendo críticas de autores como Flávia Piovesan, a qual ferrenhamente defende a indivisibilidade destes direitos. Adverte, portanto, contra uma categorização geracional, que faça sugestão a um processo de acumulação de direitos. A autora aduz que:

34 PIOVESAN, Flávia. "Concepção Contemporânea de Direitos Humanos”. In: HADDAD, Sérgio; GRACIANO, Mariângela (orgs.). A Educação entre os Direitos Humanos. São Paulo: Ação Educativa, 2006. p. 19.

${ }^{35}$ FERREIRA FILHO, Manuel Gonçalves. op. cit. p. 288.

${ }^{36}$ TAVARES, André Ramos. Curso de Direito Constitucional. $5^{\text {a }}$ ed. São Paulo: Saraiva, 2007. pp.78-79.

${ }^{37}$ Trecho extraído do voto proferido no STF - Pleno - MS n ${ }^{\circ} \mathbf{2 2 . 1 6 4 / S P}-$ Rel. Min. Celso de Mello, Diário da Justiça, Seção I, 17 nov. 1995, p. 39.206. 


\begin{abstract}
"Logo, apresentando os direitos humanos uma unidade indivisível, revela-se esvaziado o direito à liberdade, quando não assegurado o direito à igualdade e, por sua vez, revela-se esvaziado o direito de igualdade, quando não assegurada a liberdade. Vale dizer, sem a efetividade dos direitos econômicos, sociais e culturais, os direitos civis e políticos se reduzem a meras categorias formais, enquanto que, sem a realização dos direitos civis e políticos, ou seja, sem a efetividade da liberdade entendida em seu mais amplo sentido, os direitos econômicos e sociais carecem de verdadeira significação. Não há mais como cogitar da liberdade divorciada da justiça social, como também infrutífero pensar na justiça social divorciada da liberdade. Em suma, todos os direitos humanos constituem um complexo integral, único e indivisível, em que diferentes direitos estão necessariamente inter-relacionados e interdependentes entre si" ${ }^{38}$
\end{abstract}

Portanto, os direitos econômicos, sociais e culturais, apesar de seu aparecimento tardio, não podem ser vistos como dissociados dos direitos civis e políticos, que os precederam historicamente. No ensinamento de José Afonso da Silva, os direitos de segunda geração "valem como pressupostos do gozo dos direitos individuais na medida em que criam condições materiais mais propícias ao aferimento da igualdade real, o que, por sua vez, proporciona condição mais compatível com o exercício efetivo da liberdade". ${ }^{39}$

Outras críticas a essa visão geracional dos direitos humanos dizem respeito à cronologia costumeiramente ligada ao seu aparecimento e desenvolvimento. A partir de estudo clássico elaborado pelo britânico Thomas Marshall, em 1967, costumou-se identificar uma evolução a partir da concessão de direitos civis ao final do século XVIII, seguida pela universalização do sufrágio por meio da extensão dos direitos políticos ao longo do século $\mathrm{XIX}$, encerrando-se no reconhecimento de direitos sociais no século $\mathrm{XX}^{40}$ Contudo, o historiador José Murilo de Carvalho demonstra que esse crescendo jurídico não se repete universalmente, como prova a própria história constitucional brasileira. ${ }^{41}$

A guisa de conclusão, podemos inferir que o próprio direito à educação consiste na negação de uma visão apartada dos direitos enquanto categorias geracionais, na medida em que, conforme já mencionamos na introdução, encerra simultaneamente uma dimensão jurídica individual e coletiva, fundamental e universal. ${ }^{42}$

\footnotetext{
${ }^{38}$ PIOVESAN, Flávia. Temas de Direitos Humanos. $2^{\mathrm{a}}$ ed. ampl. e at. São Paulo: Max Limonad, 2003. p. 3637.

${ }^{39}$ SILVA, José Afonso da. op. cit. p. 277.

${ }^{40}$ MARSHALL, Thomas H. Cidadania, Classe Social e Status. Rio de Janeiro: Zahar, 1967.

${ }^{41}$ No Brasil, diferentemente do proposto por Marshall, os direitos sociais foram primeiramente concedidos pela Constituição de 1934, período em que a ditadura de Getulio Vargas suprimiu os direitos políticos e restringiu os direitos civis, Cf. CARVALHO, José Murilo. Cidadania no Brasil - o Longo Caminho. Rio de Janeiro: Civilização Brasileira, 2002.

${ }^{42}$ RANIERI, Nina. O Estado Democrático de Direito, op. cit. pp. 286-288.
} 


\section{$\underline{\text { 1.1.1 - O Direito à Educação nas Primeiras Constituições Mercosulinas }}$}

A doutrina sói apontar a Constituição Mexicana (1917) e a da República de Weimar (1919) como os primeiros textos constitucionais a reconhecer e positivar os direitos econômicos e sociais. Entretanto, a temática da educação não tardou tanto a aparecer nos textos constitucionais dos Estados-membros do MERCOSUL, estando presente em todas as primeiras Cartas nacionais, já no século XIX. Note-se, igualmente, que os referidos textos constitucionais concedem importante deferência à educação em seu nível de ensino primário.

O texto constitucional brasileiro de 1824 inaugurou a constitucionalização do direito à educação no subcontinente, ao estabelecer, em seu artigo 179, parágrafo 32, a gratuidade da instrução primária a todos os cidadãos. Posto que o termo "cidadãos" restringia sobremaneira a extensão desta prestação estatal, uma vez que a sociedade monarquista brasileira conviveria com a escravidão até 1888, é preciso reconhecer que a precocidade do texto constitucional de 1824 , colocando o Brasil entre os primeiros países do mundo a reconhecer esse direito. ${ }^{43}$

A Constituição Uruguaia de 1830, primeira Carta Magna do país, também tratou da questão, ao estabelecer que os governos departamentais deveriam velar sobre a educação primária, por meio da instauração de Juntas intituladas "Econômico-Administrativas", com membros eleitos por eleição direta. ${ }^{44}$

A Constituição Paraguaia de 1844 estipulava no artigo 19 do rol de atribuições do Presidente da República, a função de "promover e fomentar" os estabelecimentos de "educación primaria y los de ciencias mayores", 45 os quais seriam custeados pelo orçamento

\footnotetext{
${ }^{43}$ LIMA, Maria Cristina de B. op. cit. p. 5. Também: RANIERI, Nina. O Estado Democrático de Direito op. cit. pp. 292-293.

${ }^{44}$ A Constituição Uruguaia de 1830 foi promulgada em 28 de junho deste ano e somente perdeu sua vigência em 1918. Em seu artigo 126, enumera os objetivos da criação das Juntas Econômico-Administrativas: “Artículo 126 - Su principal objeto será promover la agricultura, la prosperidad y ventajas del Departamento en todos sus ramos: velar así sobre la educación primaria, como sobre la conservación de los derechos individuales; y proponer a la Legislatura y al Gobierno todas las mejoras que juzgaren necesarias o útiles". Texto disponível em: http://www.parlamento.gub.uy/Constituciones/Const830.htm. Acesso em 27 de fevereiro de 2010.

${ }^{45}$ Frise-se que a numeração dos artigos na Constituição Paraguaia de 1844 reiniciava sua contagem ao início de cada título. Esta lei fundamental foi suplantada pela Constituição de 1870, promulgada ao final da Guerra do Paraguai. O texto da Constituição Paraguaia de 1844, bem como dos atos políticos anteriores, encontra-se em http://www.tsje.gov.py/constituciones.php. Acesso em 27 de fevereiro de 2010.
} 
nacional e inspecionados pelo Chefe do Executivo. ${ }^{46}$ Ademais, consoante o artigo 27 do mesmo título, o Presidente da República também se responsabilizava pela formulação de planos gerais ou particulares de educação pública, os quais seriam submetidos à aprovação da Representação Nacional, órgão legislativo nacional.

A Constituição Argentina de 1853 estabeleceu, em sua redação original, a educação primária gratuita como atribuição das Províncias Confederadas, devendo obrigatoriamente as constituições provinciais assegurar a sua garantia, conforme o disposto no artigo $5^{\circ}$ do mencionado diploma legal:

\begin{abstract}
Artículo 5: Cada Provincia Confederada dictará para sí una Constitución bajo el sistema representativo republicano, de acuerdo con los principios, declaraciones y garantías de la Constitución Nacional; y que asegure su administración de justicia, su régimen municipal y la educación primaria gratuita. Las constituciones provinciales serán revisadas por el Congreso antes de su promulgación. Bajo de estas condiciones el Gobierno Federal, garante a cada Provincia el goce y ejercicio de sus instituciones.
\end{abstract}

É interessante mencionar que a atual redação do artigo $5^{\circ}$ da lei fundamental argentina não reproduz o requisito da gratuidade, afirmando apenas a competência provincial na administração da educação primária, conforme veremos em maior detalhes no item seguinte.

\title{
1.2 - Breve Análise Acerca das Constituições Vigentes dos Estados-Membros do MERCOSUL
}

É impossível dissociar, mesmo numa breve análise, a trajetória política dos Estados e os seus produtos normativos mais importantes, a saber, as Constituições Nacionais. O histórico constitucional entre os quatro países apresenta pontos de contato e de divórcio. Entre os pontos de contato, podemos afirmar que os quatro Estados estudados comungam de uma trajetória política bastante semelhante, sobretudo ao longo do século $\mathrm{XX}$, quando grassaram inúmeros golpes de estado.

\footnotetext{
${ }^{46}$ Constituição Paraguaia de 1844, Título VII, art. 30.
} 
Na visão de Samuel Huntington, os quatro países vivenciaram períodos de democratização e ruptura semelhantes, de acordo com as ondas específicas que caracterizariam o gradual progresso em prol da universalização do modelo democrático. ${ }^{47} \mathrm{~A}$ redemocratização, como se verá, possui fundamental importância tanto no processo de redefinição das garantias constitucionais - todas as Cartas Magnas mercosulinas serão emendadas, reformadas ou derrogadas - quanto na intensificação do processo de aproximação política com vistas à regionalização, conforme se verá no Capítulo 3.

Outro ponto importante de aproximação se expressa pela adoção do regime presidencialista, sob a forma de governo republicana, tradição continental cultivada após a criação deste regime pelos Estados Unidos da América, em sua constituição de $1787 .{ }^{48}$ Como notável exceção à regra, ${ }^{49}$ o Brasil adotou o republicanismo presidencialista apenas com o advento da Constituição de 1891, após 65 anos de monarquia parlamentarista, entre os anos de 1824 e 1889. O país ainda voltou a conhecer um breve regime de natureza parlamentar entre 1961 e 1964.

Entre os pontos dissonantes, salientamos a opção pelo federalismo, realizada pelos pela Argentina e Brasil, em face da adoção do modelo unitário descentralizado, no Paraguai e

\footnotetext{
${ }^{47}$ Pela classificação elaborada pelo autor, a primeira onda de democratização, a mais longa de todas, estendeu-se entre 1828 e 1926, embebida dos ideais revolucionários franceses. Caracterizou-se, sobretudo, pela afirmação dos direitos civis e gradual concessão do direito ao sufrágio. Contudo, tal onda foi interrompida pelos regimes autoritários e totalitários que conduziram à Segunda Guerra Mundial. O fim do conflito restabeleceu o processo de expansão do número de regimes democráticos, de tal modo que os anos compreendidos entre 1945 e 1962 são identificados como a segunda onda de democratização, interrompida muita em função das descolonizações africanas e asiáticas, as quais ensejaram regimes autoritários em sua maioria, além dos golpes militares na América Latina. Essa segunda onda reserva teve duração abreviada pela restauração democrática dos países do sul da Europa e a redemocratização dos Estados latino-americanos. Assinala ainda o autor que a terceira onda já congrega o maior número de países democráticos da história. Cf. HUNTINGTON, Samuel. Terceira Onda de Democratização.São Paulo: Ática, 1994. Consentindo, Francis Fukuyama alardearia, neste mesmo contexto, o fim da história, entendida como o encerramento do movimento dialético, pelo qual o modelo de justiça social e econômico seria aperfeiçoado. Trata-se, portanto, da consagração do liberalismo econômico e democracia liberal, Cf. FUKUYAMA, Francis. O Fim da História e o Último Homem. Rio de Janeiro: Rocco, 1992. Contudo, a nosso ver, o modelo democrático tem sido questionado mundialmente pelo fundamentalismo islâmico e ideologias políticas latino-americanas.

${ }^{48}$ Para um estudo historiográfico mais aprofundado acerca do presidencialismo nos países do MERCOSUL, ver WINTER, Luís Alexadre Carta. A História do Presidencialismo nos Países do MERCOSUL. In: GOMES, Eduardo Biacchi; REIS, Tarcísio Hardman (org.). A Integração Regional no Direito Internacional. São Paulo: Lex Editora, 2006. pp. 51-100.

49 Também o Uruguai conheceu um período de exceção à normalidade presidencialista, vez que o Congresso uruguaio, temendo um golpe militar, aboliu a função de Presidente da República em 1951, instituindo um Conselho de Administração bipartidista como detentor do Poder Executivo. Tal situação perdurou até a promulgação da Constituição uruguaia ainda vigente, em 1967.
} 
Uruguai. Tal opção influirá sobremaneira na divisão de competências envolvendo a temática da educação, bem como nos mecanismos de financiamento.

É relevante mencionar também as diferenças com relação à utilização do Poder Constituinte derivado. Enquanto o Brasil abusa do mecanismo de emendas constitucionais, Uruguai e Argentina promovem reformas também extensas, porém concentradas em períodos determinados. Destoante do restante do bloco, a Argentina conheceu apenas um ordenamento constitucional ao longo de sua trajetória política. Contudo, face à extensão das reformas operadas ao longo do texto, é possível questionarmos em que medida subsiste a mesma ordem jurídica. Apresentamos a seguir, um quadro sinóptico do histórico constitucional dos países estudados:

\section{Q.2 - Histórico Constitucional dos Estados-Membros do MERCOSUL}

\begin{tabular}{|c|c|c|c|c|}
\hline \multicolumn{2}{|c}{ Quesitos } & Frgentina & Brasil & Paraguai \\
\hline $\begin{array}{c}\text { Forma de Estado } \\
\text { Constitucional }\end{array}$ & Federação & Federação & Unitário & Unitário \\
\hline $\begin{array}{c}\text { Número de Textos } \\
\text { Constitucionais }\end{array}$ & 01 & 07 & 05 & 06 \\
\hline $\begin{array}{c}\text { Período de Ruptura } \\
\text { Democrática }\end{array}$ & $\begin{array}{c}1966-1973 \mathrm{e} \\
1976-1983\end{array}$ & $1964-1984$ & $1945-1988$ & $1973-1984$ \\
\hline $\begin{array}{c}\text { Data de Promulgação } \\
\text { Constituição Vigente }\end{array}$ & 01.05 .1853 & 05.10 .1988 & 20.06 .1992 & $15.02 .1967^{50}$ \\
\hline & 1860,1866, & & & 1989,1994, \\
Reformas ou Emendas & 1898,1957 e & 59 emendas & 02 emendas & 1996 e 2004 \\
\hline
\end{tabular}

Feitas estas breves considerações acerca das Cartas Magnas MERCOSULinas, necessárias na medida em que demonstram as variedades de tradições políticas e jurídicas no

\footnotetext{
${ }^{50}$ Posto que a Constituição Uruguaia tenha entrado em vigor nesta data, o texto constitucional foi objeto de plebiscito no dia 27.11.1966.
} 
subcontinente, passaremos a analisar propriamente o tratamento constitucional concedido ao direito à educação básica.

\section{3 - Normas Constitucionais de Direitos à Educação Básica no MERCOSUL}

Utilizaremos este item para apresentar as disposições constitucionais a respeito do direito à educação, com ênfase na educação básica. As diferenças de tratamento constitucional serão apresentadas didaticamente por meio de quadros comparativos ao final desta seção. Cumpre mencionar que o nosso estudo considerou apenas as normas constitucionais positivadas no corpo da Carta Magna, por força do poder constituinte originário ou derivado. Não trataremos aqui, portanto, do bloco de constitucionalidade. Deparando-nos com o caso argentino, que concede hierarquia constitucional a um rol específico de tratados internacionais, ${ }^{51}$ preferimos tratar de sua proteção em um momento posterior.

\section{$\underline{1.3 .1 \text { - Argentina }}$}

A Constituição Argentina (CA) é bastante lacônica no que tange o direito à educação. A palavra "educación" é mencionada apenas sete vezes, superando em número de aparições a palavra "enseñanza", presente em uma passagem constitucional. Não obstante sua pouca participação no plano constitucional, o direito a ensinar e aprender é consagrado pelo artigo 14 da Lei Maior argentina, ressalvando, ainda, que o exercício deste direito se dará pelas formas legais que o regulamentem ${ }^{52}$.

\footnotetext{
${ }^{51}$ Constituição Argentina, art. 75, inciso 24. Trataremos mais a esse respeito quando cuidarmos da integração das normas internacionais às constituições nacionais dos países aqui estudados.

${ }^{52}$ Constituição Argentina, art. 14: "Todos los habitantes de la Nación gozan de los siguientes derechos conforme a las leyes que reglamenten su ejercicio; a saber: de trabajar y ejercer toda industria lícita; de navegar y comerciar; de peticionar a las autoridades; de entrar, permanecer, transitar y salir del territorio argentino; de publicar sus ideas por la prensa sin censura previa; de usar y disponer de su propiedad; de asociarse con fines útiles; de profesar libremente su culto; de enseñar y aprender." (grifos nossos)
} 
Contudo, o tema da educação encontra maior guarida no artigo 75 da Carta argentina, responsável pela apresentação do rol de atribuições do Poder Legislativo do país:

19. Sancionar leyes de organización y de base de la educación que consoliden la unidad nacional respetando las particularidades provinciales y locales; que aseguren la responsabilidad indelegable del estado, la participación de la familia y la sociedad, la promoción de los valores democráticos y la igualdad de oportunidades y posibilidades sin discriminación alguna; y que garanticen los principios de gratuidad y equidad de la educación pública estatal y la autonomía y autarquía de las universidades nacionales.

Posto que a incumbência constitucional acerca da organização do sistema educacional recaia sobre o Congresso nacional argentino, o artigo $5^{\circ}$ do texto constitucional antevê significativa distinção à educação primária ${ }^{53}$, incumbindo explicitamente às províncias a tarefa de sua promoção, por meio das constituições provinciais ${ }^{54}$.

A fim de assegurar o pleno exercício do direito à educação aos grupos entendidos como mais vulneráveis da sociedade, a CA, ainda em seu artigo 75, prevê medidas protetivas a alguns grupos em particular:

17. Reconocer la preexistencia étnica y cultural de los pueblos indígenas argentinos. Garantizar el respeto a su identidad y el derecho a una educación bilingüe e intercultural;

23. Legislar y promover medidas de acción positiva que garanticen la igualdad real de oportunidades y de trato, y el pleno goce y ejercicio de los derechos reconocidos por esta Constitución y por los tratados internacionales vigentes sobre derechos humanos, en particular respecto de los niños, las mujeres, los ancianos y las personas con discapacidad.

Dictar un régimen de seguridad social especial e integral en protección del niño en situación de desamparo, desde el embarazo hasta la finalización del período de enseñanza elemental, y de la madre durante el embarazo y el tiempo de lactancia.

Frise-se que não há, ao longo de todo o texto constitucional argentino, qualquer menção à obrigatoriedade ou gratuidade da educação, em qualquer nível, no país. Por fim, a

\footnotetext{
${ }^{53}$ Nível de ensino argentino destinado aos educandos entre seis e onze anos, conforme veremos no item seguinte.

${ }^{54}$ Também, neste sentido, o artigo 125 enuncia que “(...) las provincias y la ciudad de Buenos Aires pueden conservar organismos de seguridad social para los empleados públicos y los profesionales; y promover el progreso económico, el desarrollo humano, la generación de empleo, la educación, la ciencia, el conocimiento y la cultura".
} 
Carta Magna argentina também prevê que sejam adotadas medidas para o oferecimento de uma educação que promova a preservação do meio ambiente e o consumo equilibrado. ${ }^{55}$

\section{$\underline{1.3 .2-\text { Brasil }}$}

Conforme já mencionamos, o Brasil foi o primeiro Estado-membro do MERCOSUL a tratar da educação em seu texto constitucional. Talvez em razão desta larga tradição ${ }^{56}$, a Constituição Brasileira (CB) de 1988 trata extensamente sobre a temática, estando presente, direta ou indiretamente, em nada menos que 22 artigos ao longo do texto constitucional e 04 artigos no Ato das Disposições Constitucionais Transitórias (ADCT). Não obstante sua presença difusa na Carta Magna, a educação goza, contudo, de uma topologia constitucional privilegiada, entre os artigos 205 e 214, dentro do Título III - Da Ordem Social, Capítulo III - Da Educação, da Cultura e do Desporto, Seção I - Da Educação.

O texto constitucional brasileiro inclui o direito à educação no rol dos direitos sociais elencados no caput do artigo $6^{\circ} .^{57}$ Entretanto, é no artigo 205 da Carta que encontramos a afirmação categórica deste direito, bem como de sua finalidade:

\footnotetext{
${ }_{55}^{55}$ Constituição Argentina, arts. 41 e 42.

${ }^{56}$ A propósito de realizar um estudo da evolução do direito à educação ao longo das constituições brasileiras, Romualdo Portela Oliveira assinala as principais características normativas deste percurso, no seu entender: "a) a obrigatoriedade escolar para o ensino primário é introduzida, em nível constitucional, a partir de 1934, com cinco anos de duração. Amplia-se o seu período de duração para oito anos no texto de 1967 e, com a Lei 5.962/71; altera-se a nomenclatura da educação elementar para o ensino de primeiro grau, fundindo-se aí os antigos ensino primário e ginasial. Dessa forma, o ensino obrigatório passa a abarcar esse novo nível, mantendose tal direito restrito à faixa etária dos 7 aos 14 anos de idade; b) garante-se a gratuidade no período de escolarização compulsória, verificando-se apenas uma exceção, em 1937, quando se apresentam senões à idéia de gratuidade indiscriminada para esse nível de ensino; c) abandona-se a idéia da progressiva extensão da gratuidade ao ensino ulterior ao primário, presente em 1934, substituída pela gratuidade para os que provarem insuficiência de recursos, chegando-se mesmo a prever a introdução do mecanismo de bolsas restituíveis (em 1967); d) revela-se a influência das concepções católicas a respeito da definição das instituições responsáveis pela educação, com primazia da família sobre os poderes Públicos (1934) ou no ensino ministrado no lar e na escola (1946 e 1967); e) não são previstos, explicitamente, mecanismos jurídicos para a garantia de tal direito, apesar de haver a possibilidade do recursos ao mandado de segurança; f) não se menciona a educação infantil como integrante do direito à educação nas prescrições educacionais das Constituições analisadas; g) explicita-se, apenas no texto de 1969, o dever do Estado em garantir a educação compulsória para todos", Cf. OLIVEIRA, Romualdo P. "O Direito à Educação". In: OLIVEIRA, Romualdo P.; ADRIÀO, Theresa (orgs.). Gestão, Financiamento e Direito à Educação. São Paulo: Xamã, 2001, pp. 22-23.

${ }^{57}$ De acordo com Marcos Neri de Almeida, a identificação da educação enquanto direito social pela CB pelo artigo $6^{\circ}$, corresponde à "norma de conformação do sistema, ditando o conteúdo de toda a normatização infraconstitucional e, enquanto direito fundamental, deve ser objeto de máxima efetividade, concretizada através de leis, atos normativos e posturas administrativas que lhe dêem a maior efetividade possível. Além disso, é um comando de aplicabilidade imediata, constituindo-se, por consequência, em direito subjetivo dos indivíduos",
} 
Art. 205. A educação, direito de todos e dever do Estado e da família, será promovida e incentivada com a colaboração da sociedade, visando ao pleno desenvolvimento da pessoa, seu preparo para o exercício da cidadania e sua qualificação para o trabalho.

A obrigatoriedade e gratuidade da prestação do serviço educacional no Brasil vem sofrendo diversas revisões constitucionais ao longo dos últimos quinze anos. Enquanto o texto original previa um ensino obrigatório e gratuito apenas aos alunos do antigo nível fundamental, que compreendia crianças entre sete e quatorze anos, a Emenda Constitucional n. 14/96 estabeleceu a progressiva universalização do ensino médio gratuito, nível de ensino voltado aos educandos entre quinze e dezessete anos. A Emenda Constitucional 53/06, por sua vez, avençou a assistência gratuita aos filhos e dependentes dos trabalhadores urbanos e rurais, desde o nascimento aos cinco anos de idade, em creches e pré-escolas ${ }^{58}$.

Entretanto, a maior alteração advém da aprovação da Emenda Constitucional 59/09, aprovada em 11 de novembro de 2009. Mediante alteração no inciso I do artigo 208, estabeleceu-se a obrigatoriedade e gratuidade do ensino entre os quatro e dezessete anos de idade, compreendendo, portanto, desde a educação infantil até o ensino médio completo:

Art. 208. O dever do Estado com a educação será efetivado mediante a garantia de:

I - educação básica obrigatória e gratuita dos 4 (quatro) aos 17 (dezessete) anos de idade, assegurada inclusive sua oferta gratuita para todos os que a ela não tiveram acesso na idade própria;

Notadamente, é preciso reconhecer que ao longo do período indicado, o Brasil alcançou patamar muito próximo da universalização do ensino fundamental, de modo que gradativamente tem voltado sua atenção para os outros níveis de ensino da educação básica. Ademais, a respeito do ensino básico, a mesma emenda constitucional prevê o dever do Estado na adoção de medidas que colaborem no combate à evasão escolar, auxiliando os educandos com o oferecimento de programas suplementares de material didático-escolar, transporte, alimentação e assistência à saúde, ao longo de todos os ciclos da educação básica $^{59}$.

Cf. ALMEIDA, Marcos Neri de. O Direito à Educação Infantil e a Discricionariedade Administrativa. Dissertação de Mestrado em Direito das Relações Sociais: PUC, 2008. p.14.

${ }^{58}$ Constituição Brasileira, art. $7^{\circ}$, inciso XXV.

${ }^{59}$ Constituição Brasileira, art. 208, inciso VII. Interessante mencionar que estes programas de alimentação e assistência à saúde serão financiados por contribuições sociais e outros recursos orçamentários, consoante o disposto no art. $212, \S 4^{\circ}$, da CB. Não integram, portanto, o orçamento destinado à educação previsto no caput 
Frise-se, ainda, que a prestação deste serviço educacional, consoante o disposto na $\mathrm{CB}$, configura-se direito público subjetivo, sendo que o não-oferecimento ou seu oferecimento irregular acarreta na responsabilização da autoridade pública competente ${ }^{60}$. Nas palavras de Ricardo Torres,

“[a] elevação do direito à educação como subjetivo público confere-lhe o status de direito fundamental, mínimo existencial, arcando o Estado, nos limites propostos, com prestações positivas e igualitárias, cabendo a este, também, através de sua função jurisdicional, garantir-lhes a execução". ${ }^{1}$

O texto constitucional também versa sobre a estrutura do sistema educacional brasileiro. Comparativamente aos outros sistemas de ensino da região, o Brasil apresenta acentuada descentralização administrativa, reforçada pela opção política pelo federalismo, o que impulsiona, também, uma descentralização das políticas educacionais, assentadas na autonomia dos entes federados.

Desta forma, o texto constitucional atesta a competência privativa da União para a definição de diretrizes e bases da educação nacional ${ }^{62}$ e também prevê a competência comum entre todos os entes federados quanto a "proporcionar os meios de acesso à cultura, à educação e à ciência"63. A respeito da legislação educacional infraconstitucional, determina a competência concorrente entre a União, Estados e o Distrito Federal ${ }^{64}$.

Quanto à prestação dos serviços educacionais, a legislação vigente determina as atuações prioritárias de cada dos entes federados, de acordo com uma divisão proposta pelos níveis de ensino. Vejamos.

Consoante o disposto no artigo 211, $\S 2^{\circ}$ da CB, os municípios atuam prioritariamente na prestação de serviços educacionais nos níveis infantil e fundamental, mediante cooperação

\footnotetext{
do artigo 212 do referido diploma legal. O texto constitucional é silente em relação ao financiamento dos demais programas.

${ }^{60}$ Constituição Brasileira, art. 208, $\S \S 1^{\circ}$ e $2^{\circ}$.

${ }^{61}$ TORRES, Ricardo Lobo. Direitos Humanos e a Tributação - Imunidades e Isonomia. Rio de Janeiro: Renovar, 1995. p. 151. Para um estudo mais

${ }^{62}$ Constituição Brasileira, art. 22, inciso XXIV.

${ }^{63}$ Constituição Brasileira, art. 23, inciso V.

${ }^{64}$ Constituição Brasileira, art. 24, inciso IX.
} 
técnica e financeira dos demais entes federados ${ }^{65}$. Os Estados e o Distrito Federal, por sua vez, concentram esforços nos níveis fundamental e médio, por força do $\S 3^{\circ}$ do mencionado artigo. O ensino superior não é mencionado pelo artigo 211, porém recebe atenção especial dos Estados e da União, a qual também possui uma função supletiva e redistributiva no sistema educacional, auxiliando técnica e financeiramente aos outros entes federados. ${ }^{66}$

Contudo, frise-se que a determinação apenas determina os níveis prioritários de ensino, de forma a servir como parâmetro para a versação dos recursos orçamentários, não vedando ou restringindo a atuação dos entes federados em outros níveis educacionais.

O texto constitucional também trata da questão do financiamento do sistema educacional brasileiro. O artigo 212 da CB prevê a aplicação, como patamar mínimo de investimento para a manutenção e desenvolvimento do ensino, pela União, de $18 \%$ sobre o montante auferido da receita de impostos, compreendidas aí as transferências constitucionais. Para os demais entes federados, a legislação aponta uma parcela ainda maior, atingindo $25 \%$ das receitas mencionadas. É importante, no entanto, fazer a ressalva de que as Constituições estaduais ou Leis Orgânicas poderão estabelecer outros parâmetros mais rigorosos de aplicação de recursos educacionais. ${ }^{67}$

Esses recursos deverão ser empenhados prioritariamente no fornecimento do ensino obrigatório, almejando-se sua universalização com qualidade e equidade, conforme redação do $\S 3^{\circ}$ do artigo 212 da CB, ditada pela Emenda Constitucional 59/09. Especificamente para a educação básica, neste mesmo artigo a Emenda Constitucional n. 53/06 realizou modificações importantes. Enquanto a redação atual do $\S 5^{\circ}$ prevê a contribuição do salárioeducação como fonte adicional de financiamento, a inserção do $\S 6^{\circ}$ determina a sua distribuição proporcional aos Estados e Municípios, de acordo com o número de alunos matriculados na rede pública de educação básica.

\footnotetext{
${ }^{65}$ Também neste sentido, ver art. 30, inciso VI da CB.

${ }^{66}$ Constituição Brasileira, art. $211, \S 1^{\circ}$.

${ }^{67}$ Conforme nos ensina Marcos Neri de Almeida, à guisa de exemplo, "a Constituição do Estado de São Paulo e a Lei Orgânica do Município de São Paulo foram além, ao dispor que o Estado e o Município aplicarão, anualmente, na manutenção e no desenvolvimento do ensino público, no mínimo, $30 \%$ da receita resultante de impostos, incluindo recursos provenientes de transferências (art. 255 da Constituição Estadual e art. 208 da Lei Orgânica Municipal)", $C f$, ALMEIDA, Marcos Neri de. op. cit. p. 33.
} 
A salutar preocupação com a educação básica, no entanto, incentivou a criação, no âmbito de cada Estado e do Distrito Federal, do FUNDEB (Fundo de Manutenção e Desenvolvimento da Educação Básica e de Valorização dos Profissionais da Educação), em substituição ao FUNDEF (Fundo de Manutenção e Desenvolvimento do Ensino Fundamental e Valorização do Magistério) ${ }^{68}$, por meio da Emenda Constitucional 53/06, responsável por revisar largamente o art. 60 do ADCT.

A finalidade precípua do FUNDEB é garantir o financiamento do desenvolvimento e manutenção da educação básica pelos entes federados, bem como a melhoria na remuneração dos profissionais envolvidos na educação ${ }^{69}$, resultando no incremento da qualidade de ensino no âmbito nacional.

Consoante a nova redação fornecida pela Emenda Constitucional 53/06, o fundo é composto pelas seguintes receitas, previstas no art. 60, inciso II da ADCT:

\begin{abstract}
"II - os Fundos referidos no inciso I do caput deste artigo serão constituídos por $20 \%$ (vinte por cento) dos recursos a que se referem os incisos I, II e III do art. 155; o inciso II do caput do art. 157; os incisos II, III e IV do caput do art. 158; e as alíneas a e b do inciso I e o inciso II do caput do art. 159, todos da Constituição Federal, e distribuídos entre cada Estado e seus Municípios, proporcionalmente ao número de alunos das diversas etapas e modalidades da educação básica presencial, matriculados nas respectivas redes, nos respectivos âmbitos de atuação prioritária estabelecidos nos $\S \S 2^{\circ}$ e $3^{\circ}$ do art. 211 da Constituição Federal". 70
\end{abstract}

Note-se que estes valores serão deduzidos do total destinado à educação previsto no caput do artigo 212 da CB, o qual já foi mencionado. Estabelece-se, ainda, a possibilidade de complementação financeira por parte da União, de forma a capacitar os Fundos a atingir o valor anual mínimo por aluno da educação básica ${ }^{71}$. Este valor, por sua vez, é obtido mediante cálculo previsto no Plano Nacional de Educação. Caso não sejam realizados os

\footnotetext{
${ }^{68}$ O FUNDEF havia sido criado pela Emenda Constitucional 14/96.

${ }^{69}$ De acordo com o art. 60, inciso XII, a remuneração dos profissionais do magistério da educação básica em efetivo exercício consumirá, no mínimo, $60 \%$ do valor total auferido pelo fundo.

${ }^{70}$ Cumpre informar que a redação anterior, dada pela Emenda Constitucional 14/96, previa apenas $15 \%$ do total dos impostos mencionados pelo inciso II. Todavia, esta proporção será alcançada gradativamente ao longo de três anos, conforme dispõe o $\S 5^{\circ}$ do art. 60 do ADCT.

${ }^{71} \mathrm{O}$ inciso VII do art. 60 do ADCT dispõe uma complementação obrigatória anual por parte da União, a qual atingirá dez por cento do total previsto no mencionado inciso II, após o seu quarto ano de constituição.
} 
repasses previstos pela União, o inciso XI do art. 60 prevê a configuração de crime de responsabilidade da autoridade competente.

Ademais, é preciso mencionar outra deferência concedida à educação básica em matéria orçamentária, visto que as receitas auferidas a título do salário-educação ${ }^{72}$ constituem exceção à vedação de vinculação de receitas de impostos, conforme previsto no $\S 2^{\circ}$, art. 76 do ADCT, inserido pela Emenda Constitucional 27/00 ${ }^{73}$. De maneira a conferir ainda maior proteção ao orçamento educacional, a Emenda Constitucional 59/09 inseriu o $\S 3^{\text {o }}$ no mencionado artigo, com a seguinte redação:

$\S 3^{\circ}$ Para efeito do cálculo dos recursos para manutenção e desenvolvimento do ensino de que trata o art. 212 da Constituição, o percentual referido no caput deste artigo será de $12,5 \%$ (doze inteiros e cinco décimos por cento) no exercício de 2009 , $5 \%$ (cinco por cento) no exercício de 2010, e nulo no exercício de 2011.

O não-cumprimento destas previsões legais pode acarretar séria penalidade ao ente federado infrator. Segundo a Constituição Federal, há a possibilidade de intervenção estadual nos Municípios ${ }^{74}$ e federal nos Estados e no Distrito Federal ${ }^{75}$.

Por fim, a CB é a única Carta Magna MERCOSULina que prevê a realização de um Plano Nacional de Educação, de acordo com os seguintes critérios, em sua redação atual:

Art. 214. A lei estabelecerá o plano nacional de educação, de duração decenal, com o objetivo de articular o sistema nacional de educação em regime de colaboração e

\footnotetext{
72 Trata-se de contribuição social prevista no art. 212, parágrafo $5^{\circ}$ da CB. Instituído em 1964, é uma destina-se exclusivamente ao financiamento de programas, projetos e ações voltados para a educação básica pública. Apenas a título de conhecimento, é calculado com base na alíquota de 2,5\% sobre o valor total das remunerações pagas ou creditadas pelas empresas, a qualquer título, aos segurados empregados, ressalvadas as exceções legais.

${ }^{73}$ Pelo caput artigo 76 da ADCT, determinou-se a desvinculação, até 31 de dezembro de 2011, de 20\% dos valores auferidos com a arrecadação de impostos, contribuições sociais e de intervenção do domínio econômico pela União, sejam estes já instituídos ou criados até a mencionada data. Trata-se de medida política que almeja conceder à União maior flexibilidade para a composição do orçamento, em detrimento dos comprometimentos constitucionais.

74 Ou ainda a União nos municípios localizados em Território Federal, conforme Constituição Brasileira, art. 35, inciso III: “Art. 35. O Estado não intervirá em seus Municípios, nem a União nos Municípios localizados em Território Federal, exceto quando: (...) III - não tiver sido aplicado o mínimo exigido da receita municipal na manutenção e desenvolvimento do ensino e nas ações e serviços públicos de saúde;"’

75 Constituição Brasileira, art. 34, inciso VIII: “Art. 34. A União não intervirá nos Estados nem no Distrito Federal, exceto para: (...) VII - assegurar a observância dos seguintes princípios constitucionais: (...) e) aplicação do mínimo exigido da receita resultante de impostos estaduais, compreendida a proveniente de transferências, na manutenção e desenvolvimento do ensino e nas ações e serviços públicos de saúde".
} 
definir diretrizes, objetivos, metas e estratégias de implementação para assegurar a manutenção e desenvolvimento do ensino em seus diversos níveis, etapas e modalidades por meio de ações integradas dos poderes públicos das diferentes esferas federativas que conduzam a:

I - erradicação do analfabetismo;

II - universalização do atendimento escolar;

III - melhoria da qualidade do ensino;

IV - formação para o trabalho;

V - promoção humanística, científica e tecnológica do País; e,

VI - estabelecimento de meta de aplicação de recursos públicos em educação como proporção do produto interno bruto.

Salientamos que a Emenda Constitucional 59/09 foi responsável pela alteração de diversos pontos neste artigo, onde destacamos o estabelecimento da duração "decenal" frente à anterior "plurianual", como também a inserção do inciso VI, reforçando ainda mais a preocupação normativa com o cumprimento do orçamento educacional previsto.

\section{$\underline{1.3 .3-\text { Paraguai }}$}

Na Constituição Paraguaia de 1992 (CP), assim como a brasileira, o direito à educação também possui um locus constitucional próprio. Trata-se do Capítulo VII do Título II, intitulado "De La Educación y De La Cultura", o qual compreende os artigos 73 a 85 da Carta Magna ${ }^{76}$.

Contudo, assim como ocorre na constituição brasileira, a temática da educação se encontra presente ao longo de todo o texto constitucional paraguaio, sendo mencionada em outros capítulos, sobretudo quando estes tratam de grupos sociais mais vulneráveis, como por exemplo, os povos indígenas, que possuem a garantia constitucional de que a educação

\footnotetext{
${ }^{76}$ Ademais, a localização discriminada do direito à educação já estava presente na Constituição anterior, datada de 1967, Cf. SALGUEIRO, Jorge Silvero. "La Constitución de la República del Paraguay del 20 de junio de 1992”. In: Boletín Mexicano d Derecho Comparado. V. 31, n. 92, may-ago 1998. p. 522.
} 
formal paraguaia respeitará suas particularidades étnicas e culturais ${ }^{77}$, e as pessoas que necessitam de medidas excepcionais, visando à sua plena integração social ${ }^{78}$.

A CP é categórica no reconhecimento do direito à educação e na afirmação de suas finalidades:

\begin{abstract}
Artículo 73 - DEL DERECHO A LA EDUCACIÓN Y DE SUS FINES
Toda persona tiene derecho a la educación integral y permanente, que como sistema y proceso se realiza en el contexto de la cultura de la comunidad. Sus fines son el desarrollo pleno de la personalidad humana y la promoción de la libertad y la paz, la justicia social, la solidaridad, la cooperación y la integración de los pueblos; el respeto a los derechos humanos y los principios democráticos; la afirmación del compromiso con la Patria, de la identidad cultural y la formación intelectual, moral y cívica, así como la eliminación de los contenidos educativos de carácter discriminatorio.
\end{abstract}

La erradicación del analfabetismo y la capacitación para el trabajo son objetivos permanentes del sistema educativo.

No exercício deste direito, o texto constitucional paraguaio afirma que sua responsabilidade é da sociedade, recaindo-se especialmente sobre a família, os municípios e o Estado, de acordo com o disposto no artigo 75. Ademais, garante-se expressamente a liberdade de ensinar, estabelecidos como únicos requisitos a idoneidade e a integridade ética.

Acerca da obrigatoriedade e gratuidade do ensino, a CP também é bastante cristalina com relação à sua extensão:

\title{
Artículo 76 - DE LAS OBLIGACIONES DEL ESTADO
}

La educación escolar básica es obligatoria. En las escuelas públicas tendrá carácter gratuito. El Estado fomentará la enseñanza media, técnica, agropecuaria, industrial y la superior o universitaria, así como la investigación científica y tecnológica.

La organización del sistema educativo es responsabilidad esencial del Estado, con la participación de las distintas comunidades educativas. Este sistema abarcará a los sectores públicos y privados, así como al ámbito escolar y extraescolar.

\footnotetext{
${ }^{77}$ Constituição Paraguaia, art. 66: "El Estado respetará las peculiaridades culturales de los pueblos indígenas especialmente en lo relativo a la educación formal. (...)"

${ }_{78}$ Constituição Paraguaia, art. 58: "Se garantizará a las personas excepcionales la atención de su salud, de su educación, de su recreación y de su formación profesional para una plena integración social. (...)”
} 
Outro ponto que merece destaque na $\mathrm{CP}$ é a questão lingüística no ensino, uma vez que se trata do único país oficialmente bilíngüe na região MERCOSULina. O artigo 77 do texto constitucional paraguaio defende a utilização da língua materna do educando no início de sua vida escola, instruindo-se também no emprego dos dois idiomas oficiais: o espanhol e o guaraní.

No que tange à repartição de competências no campo da educação, o artigo 168, 1, estabelece aos municípios paraguaios a atribuição da livre gestão da educação, enquanto o artigo 163, 3, prevê a coordenação de ações departamentais com as atividades do governo central no âmbito da saúde e educação.

Por último, por força do disposto no artigo 85 da Constituição paraguaia, o Orçamento Geral da Nação deverá indicar à educação um montante não inferior a 20\% (vinte por cento) do total destinado à Administração Central, fazendo a ressalva, ainda, de que deste valor serão excluídos os empréstimos e as doações ${ }^{79}$.

\section{$\underline{1.3 .4 \text { - Uruguai }}$}

A Constituição uruguaia, a exemplo de sua contraparte argentina, também é bastante sucinta a respeito do direito à educação. ${ }^{80}$ Ao longo de todo o texto constitucional uruguaio, o tema da educação recebe a atenção de apenas sete artigos, salpicados ao longo do corpo constitucional. Coube, portanto, à legislação infraconstitucional estabelecer com maior liberdade os princípios e diretrizes da educação nacional.

Todavia, é curioso perceber que, diferentemente das outras Cartas Magnas sub studio, a Constituição uruguaia não proclama explicitamente seu dever na prestação dos serviços educacionais. Por outro lado, afirma-o enquanto um direito e dever dos pais:

\footnotetext{
${ }^{79}$ Constituição Paraguaia, art. 85: "Los recursos destinados a la educación en el Presupuesto General de la Nación no serán inferiores al veinte por ciento del total asignado a la Administración Central, excluidos los préstamos y las donaciones".

${ }^{80}$ Coincidentemente, trata-se da segunda Carta Magna mais antiga entre os países membros do MERCOSUL, atrás apenas, como se viu, da Argentina.
} 
"Artículo 41 - El cuidado y educación de los hijos para que éstos alcancen su plena capacidad corporal, intelectual y social, es un deber y un derecho de los padres. Quienes tengan a su cargo numerosa prole tienen derecho a auxilios compensatorios, siempre que los necesiten".

Para o bom e fiel cumprimento deste mandamento constitucional, cabe ao Estado uruguaio garantir a obrigatoriedade dos níveis de ensino primário e médio, por força do artigo 70, o qual ainda prevê a edição de uma lei específica para a garantia da efetividade desta disposição. A respeito da gratuidade, o artigo 71 estipula que se trata de utilidade social e presente em todo o sistema de ensino oficial, desde o nível primário até o nível superior.

Outro ponto de destacada presença no corpo constitucional é a liberdade de ensino, tanto para educadores quanto educandos. Neste sentido, o texto constitucional reconhece, por um lado, o direito de escolha das instituições de ensino e professores aos pais e responsáveis, bem como restringe a possibilidade de intervenção estatal nos estabelecimentos de ensino particulares. $^{81}$

Como forma de incentivo à prestação de serviços educacionais pela iniciativa privada, garante às instituições de ensino privado a exoneração de impostos nacionais e municipais, como forma de subvenção por seus serviços, nos moldes do artigo 69. Ainda a respeito da liberdade de ensino para os educadores, o artigo 76 garante o acesso, por parte de estrangeiros, às atividades docentes nos estabelecimentos públicos de ensino superior.

Por último, cumpre mencionar que o texto constitucional trata da questão da administração do sistema educacional de ensino em seu artigo 202, tema que será estudado com maior atenção no item seguinte. ${ }^{82}$

\section{$\underline{1.3 .5-\text { Quadros Comparativos }}$}

\footnotetext{
${ }^{81}$ Constituição Uruguaia, art. 68: “Queda garantida la libertad de enseñanza. La ley reglamentará la intervención del Estado al solo objeto de mantener la higiene, la moralidad, la seguridad y el orden públicos. Todo padre o tutor tiene derecho a elegir, para la enseñanza de sus hijos o pupilos, los maestros e instituciones que desee".

${ }^{82}$ Constituição Uruguaia, art. 202: "La Enseñanza Pública Superior, Secundaria, Primaria, Normal, Industrial y Artística, serán regidas por uno o más Consejos Directivos Autónomos. Los demás servicios docentes del Estado, también estarán a cargo de Consejos Directivos Autónomos, cuando la ley lo determine por dos tercios de votos del total de componentes de cada Cámara. Los Entes de Enseñanza Pública serán oídos, con fines de asesoramiento, en la elaboración de las leyes relativas a sus servicios, por las Comisiones Parlamentarias. Cada Cámara podrá fijar plazos para que aquéllos se expidan. La ley dispondrá la coordinación de la enseñanza".
} 
À guisa de conclusão, pode-se dizer que as Constituições MERCOSULinas apresentam significativas diferenças com relação à extensão da proteção ao direito à educação. Em que pesem os contextos históricos em que foram produzidas, é preciso reconhecer que as Constituições brasileira e paraguaia evidenciam uma preocupação muito maior com a temática, conforme podemos perceber por meio dos quesitos selecionados a seguir:

\section{Q.3 - O Direito à Educação nas Constituições do MERCOSUL}

\begin{tabular}{|c|c|c|c|c|c|}
\hline \multirow[b]{2}{*}{ País } & \multirow{2}{*}{$\begin{array}{c}\text { Topologia } \\
\text { Constitucional } \\
\text { Específica }\end{array}$} & \multirow{2}{*}{$\begin{array}{l}\text { Número } \\
\text { Total de } \\
\text { Artigos }^{83}\end{array}$} & \multirow{2}{*}{$\begin{array}{c}\text { Número de } \\
\text { Artigos } \\
\text { dedicados ao } \\
\text { Direito } \\
\text { Educacional }\end{array}$} & \multicolumn{2}{|c|}{ Ocorrências $^{84}$} \\
\hline & & & & Educação & Ensino \\
\hline Argentina $^{85}$ & Não & $129+17$ & 06 & 07 & 01 \\
\hline Brasil & $\begin{array}{c}\text { Sim } \\
\text { (arts. } 205 \text { a 214) }\end{array}$ & $250+97$ & 26 & 49 & 49 \\
\hline Paraguai & $\begin{array}{c}\mathrm{Sim} \\
(\text { arts. } 73 \text { a } 85)\end{array}$ & $291+20$ & 17 & 15 & 03 \\
\hline Uruguai & Não & $332+29$ & 07 & 02 & 11 \\
\hline
\end{tabular}

A Constituição Brasileira é, de longe, a que mais dispensa tinta ao direito à educação, contrastando enormemente com a uruguaia, uma vez que esta também é bastante extensa, porém extremamente omissa com relação ao direito educacional. Talvez em razão de sua menor idade, brasileiros e paraguaios, conferem um locus constitucional diferenciado ao direito à educação, sempre dentro do contexto dos direitos sociais.

\footnotetext{
${ }^{83} \mathrm{O}$ primeiro número refere-se ao texto constitucional propriamente dito, enquanto o segundo às disposições constitucionais transitórias.

${ }^{84}$ Número de vezes que as palavras aparecem ao longo do texto constitucional. Podem estar em um mesmo artigo.

${ }_{85}$ Ressaltamos novamente que os números argentinos não incluem os tratados internacionais mencionados no parágrafo 24 do artigo 75 da CA.
} 
Pautando agora nossa análise constitucional comparada na materialidade do direito à educação básica, elencamos quatro elementos-chave, a saber, a divisão de competências, financiamento, obrigatoriedade e gratuidade, para proceder à comparação. Assim, temos a seguinte configuração no plano constitucional dos Estados-membros do MERCOSUL:

\section{Q.4 - O Direito à Educação Básica nas Constituições do MERCOSUL}

\begin{tabular}{|c|c|c|c|c|}
\hline País & $\begin{array}{c}\text { Divisão de } \\
\text { Competências }\end{array}$ & Financiamento & Obrigatoriedade & Gratuidade \\
\hline Argentina & $\begin{array}{c}\text { Sim } \\
\text { (arts. } 05 \text { e 125) }\end{array}$ & Não & Não & $\begin{array}{c}\text { Sim } \\
\text { (art. 75, 23) }\end{array}$ \\
\hline Brasil & $\begin{array}{c}\text { Sim } \\
\text { (art. 211) }\end{array}$ & $\begin{array}{c}\text { Sim } \\
\left(\text { art. } 212, \S \S 5^{\circ} 6^{\circ} \text { da CB }\right. \\
\text { e art. } 60 \text { da ADCT })\end{array}$ & $\begin{array}{c}\text { Sim } \\
(\text { art. 209, I) }\end{array}$ & $\begin{array}{c}\text { Sim } \\
\text { (art. 209, I) }\end{array}$ \\
\hline Paraguai & $\begin{array}{c}\text { Sim } \\
\text { (arts. } 163 \text { e 168) }\end{array}$ & $\begin{array}{c}\text { Sim } \\
(\operatorname{art.~85)}\end{array}$ & $\begin{array}{c}\text { Sim } \\
(\operatorname{art.76)}\end{array}$ & $\begin{array}{c}\text { Sim } \\
\text { (art. 76) }\end{array}$ \\
\hline Uruguai & Não & Não & $\begin{array}{c}\text { Sim } \\
(\text { art. 70) }\end{array}$ & $\begin{array}{c}\mathrm{Sim} \\
(\operatorname{art} .71)\end{array}$ \\
\hline
\end{tabular}

É interessante perceber que quase todas as Cartas dedicam-se a delimitar a competência da educação básica, normalmente concedida aos níveis mais descentralizados da Administração Pública, tanto nos Estados federados como nos Estados unitários.

Tema recorrente no plano internacional, conforme veremos, a gratuidade é assegurada por todos os Estados mercosulinos ao longo de todo o ensino público. Por outro lado, também é garantida a obrigatoriedade do ensino e com larga extensão. ${ }^{86}$ Conforme nos ensina Romualdo Portela, a premissa da gratuidade deve ser a contrapartida da obrigatoriedade do cidadão freqüentar a escola, pois de outra forma, constituiria grave ônus para a família. ${ }^{87}$

\footnotetext{
${ }^{86}$ Veremos um quadro comparativo no próximo item, quando cotejamos os ciclos dos sistemas nacionais de educação.

87 OLIVEIRA, Romualdo P. "O Direito à Educação". In: OLIVEIRA, Romualdo P.; ADRIÀO, Theresa (orgs.). Gestão, Financiamento e Direito à Educação. São Paulo: Xamã, 2001, p. 17.
} 
Acerca do financiamento educacional, cumpre mencionar a Lei de Educação Nacional argentina prevê a garantia do financiamento do sistema educacional argentino, estabelecendo que o orçamento para fins de educação não poderá ser inferior a $06 \%$ (seis porcento) do PIB do país. ${ }^{88} \mathrm{O}$ Uruguai, de fato, não possui nenhuma referência legislativa ao financiamento da educação, o que demonstra ser uma grave falha da legislação uruguaia. Talvez em função de sua não previsão, o financiamento público do sistema educacional é o menor entre todos os países estudados ${ }^{89}$ :

\section{Gastos Públicos em Educação em todos os níveis de ensino}

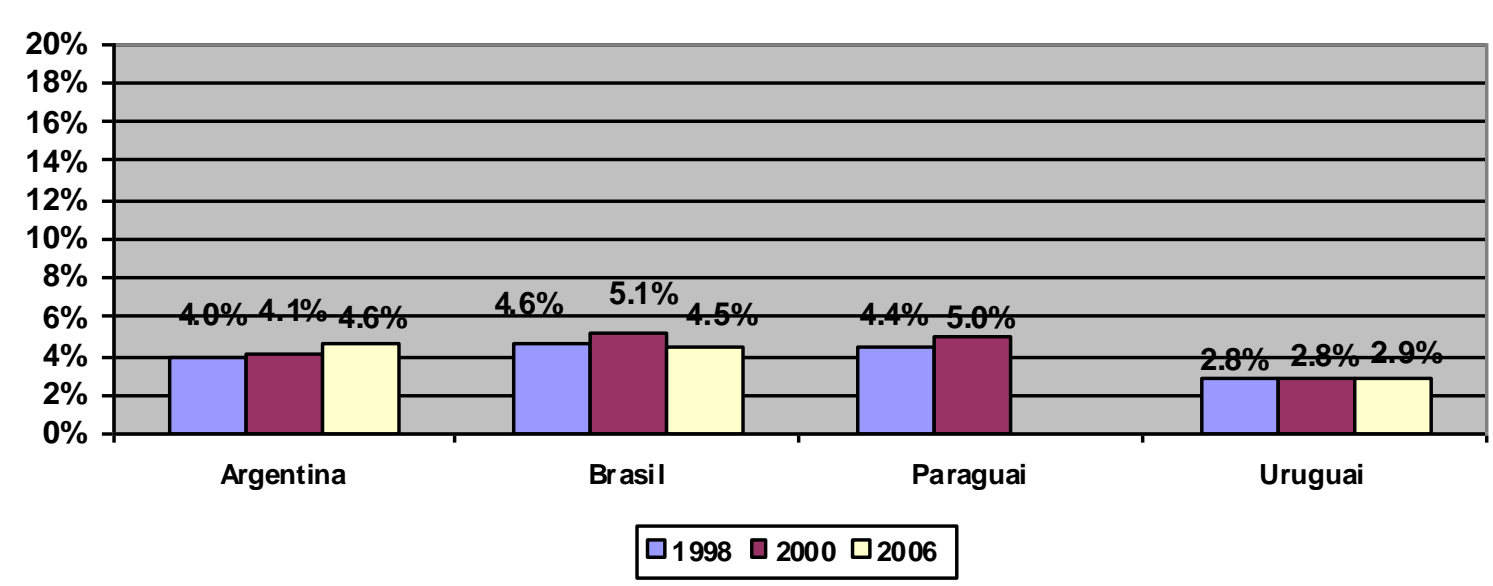

\section{4 - Breve Descrição dos Sistemas Educativos Nacionais}

Uma vez identificadas as disposições constitucionais a respeito do direito à educação básica, passaremos a empreender uma breve análise do sistema educacional contemplados nas legislações infraconstitucionais dos quatro países analisados neste estudo, a fim de estabelecer a extensão do ciclo da educação básica nos quatro países, bem como eventuais

\footnotetext{
${ }^{88}$ ARGENTINA. Ley de Educación Nacional, art. $9^{\circ}$.

${ }^{89}$ Em porcentual sobre o PIB nacional. Dados retirados de: MERCOSUL. Sistema de Informação e Comunicação do MERCOSUL EDUCATIVO. Vitrina Estadística 1998. Montevideú, 1998; MERCOSUL. Sistema de Informação e Comunicação do MERCOSUL EDUCATIVO. Vitrina Estadística 2000. Montevideú, 2000; MERCOSUL. Sistema de Informação e Comunicação do MERCOSUL EDUCATIVO. Vitrina Estadística 2006. Montevideú, 2006. Todos disponíveis em:

http://www.sic.inep.gov.br/index.php?option=com_docman\&task=cat_view\&gid=98\&Itemid=32. Acesso em 23 de janeiro de 2010. Não havia menção ao dado referente ao Paraguai em 2006.
} 
disposições infraconstitucionais específicas para a sua promoção, como a obrigatoriedade e gratuidade de seu oferecimento.

Apenas a título de explicação, a fim de possibilitar um maior conhecimento acerca das estruturas dos sistemas de ensino comparados, optou-se por manter a nomenclatura de cada um dos ciclos e modalidades de ensino em sua língua original.

\subsection{1 - Argentina}

É mister reconhecer que o país possui longa tradição na prestação educacional, auferindo excelentes níveis de educação ainda no século XIX, por meio de uma política nacional de fomento iniciada pelo Presidente Domingo Faustino Sarmiento, ao longo dos anos compreendidos entre 1868 e $1874 .{ }^{90}$ Salienta-se, outrossim, que o texto constitucional de 1853 já atribuía aos governos provinciais a responsabilidade pela educação, como vimos no item anterior. Contudo, data de 1884 a primeira lei nacional específica sobre a educação no país, a qual estabeleceu seu caráter obrigatório, laico, estatal e graduado.

Ao longo dos últimos vinte anos, o sistema de educação argentino, em virtude da redemocratização, sofreu extensas transformações, consubstanciadas em uma série de diplomas legais que alteraram profundamente a estrutura do sistema educacional no país. ${ }^{91}$

O atual desenho do sistema educacional argentino encontra-se na Lei de Educação Nacional, de 2006, a qual estabeleceu novas bases para a prestação do Estado, privilegiando uma melhora na qualidade educacional e a garantia de uma maior equidade, por meio de políticas e ações de inclusão dos setores sociais mais desfavorecidos. ${ }^{92}$

\footnotetext{
90 O dia do professor na Argentina coincide com a data de seu falecimento (11 de setembro), como reconhecimento pelos esforços empreendidos em prol da educação naquele país.

${ }^{91}$ Dentre as primeiras, destacamos a Lei Federal de Educação (1993), que tratava apresentar a organização da educação inicial, primária e secundária no país; Lei de Transferência dos Serviços Educacionais às Províncias (1995), a qual transferiu as escolas então dependentes do governo nacional às províncias; a Lei Federal de Educação Superior (1995), que organizava a educação superior no país.

${ }^{92}$ Sobre as políticas de promoção de igualdade educativa, ver os artigos 79 a 83 da Lei de Educação Nacional. As diretrizes para a qualidade educacional encontram-se nos artigos 84 a 86 do mesmo diploma legal.
} 
Com relação à estrutura do sistema nacional de educação, a referida lei estabelece, em seu artigo 12, a responsabilidade concorrente entre o Governo Nacional, as Províncias e a Cidade Autônoma de Buenos Aires no planejamento, organização, supervisão e financiamento das políticas educativas.

Outra grande inovação introduzida por este marco jurídico é a extensão da obrigatoriedade da educação argentina para 13 anos, contra 10 anos previstos pela lei anterior. Desta forma, a obrigatoriedade recai agora desde o último ano da educação inicial cursado pelas crianças de 05 anos de idade - até o término da educação secundária. ${ }^{93}$ Atualmente, o sistema educacional argentino encontra-se organizado em quatro níveis de ensino:

\section{Q.5 - Estrutura do Sistema Educacional Argentino}

\begin{tabular}{|c|c|c|}
\hline Nível de Ensino & Ciclos & Idade dos Alunos \\
\hline \multirow{2}{*}{$\begin{array}{c}\text { Cine } 00 \\
(\text { Educación Inicial })\end{array}$} & Jardín Maternal & 45 dias a 02 anos \\
\hline & Jardín de Infantes & 03 a 05 anos \\
\hline \multirow{2}{*}{$\begin{array}{c}\text { Cine } 01 \\
\text { (Educación General } \\
\text { Básica }-E G B)\end{array}$} & $E G B 1$ & 06 a 08 anos \\
\hline & $E G B 2$ & 09 a 11 anos \\
\hline \multirow{2}{*}{$\begin{array}{c}\text { Cine } 02 \text { e Cine } 03 \\
\text { (Educación Secundaria) }\end{array}$} & Básica ou EGB 3 & 12 a 14 anos \\
\hline & Polimodal & 15 a 17 anos \\
\hline \multirow{2}{*}{$\begin{array}{c}\text { Cine } 05 \text { e } 06 \\
\text { (Educación Superior) }\end{array}$} & Universitario & \multirow{2}{*}{ a partir de 18 anos } \\
\hline & No Universitario & \\
\hline
\end{tabular}

A educação inicial argentina possui como objetivo precípuo promover a inserção da criança em seu convívio familiar e comunitário, por meio do desenvolvimento dos sentimentos de amizade, solidariedade, cuidado e respeito mútuo entre as crianças. ${ }^{94}$ Posto que apenas o último ano da educação inicial seja de cumprimento obrigatório, previu-se na

\footnotetext{
${ }^{93}$ Ley de Educación Nacional, art. 16.

${ }^{94}$ Os objetivos da educação inicial argentina estão arrolados no art. 20 da Lei de Educação Nacional.
} 
Lei de Educação Nacional a universalização progressiva da prestação de serviços educacionais para as crianças a partir de 04 anos de idade. ${ }^{95}$

A educação primária no país é composta por dois ciclos de três anos cada. Este nível de ensino tem por finalidade garantir às crianças o acesso a um conjunto de conhecimentos, habilidades e atitudes, o qual lhes permita participar de maneira plena na vida familiar, escolar e comunitária. ${ }^{96}$

A educação secundária, por sua vez também apresenta estrutura bipartite. Atualmente, apresenta um primeiro ciclo, denominado básico, comum a todos os estudantes secundaristas. Num momento posterior, os alunos cursam o ciclo Polimodal, cujos conteúdos são orientados a áreas específicas do conhecimento, do mundo social e do trabalho. ${ }^{97}$ Dentro desta perspectiva, neste segundo ciclo os alunos poderão desenvolver atividades supervisionadas, ao longo de seis meses, em empresas privadas, órgãos estatais e organizações nãogovernamentais, como forma de completar o aprendizado escolar.

Cumpre salientar, no entanto, que a Lei de Educação Nacional, em seu artigo 134, concede um prazo de seis anos para que o Ministério da Educação, Ciência e Tecnologia e o Conselho Federal de Educação ${ }^{98}$ decidam entre duas estruturas para a educação primária e básica argentina: (a) seis anos para a Educação Primária e seis anos para a Educação Secundária; ou, (b) sete anos para o nível primário e cinco anos para o secundário. Até a decisão, porém, cada jurisdição escolar pode adotar a fórmula que lhe convier. ${ }^{99}$

A educação superior na Argentina possui raízes históricas profundas, deitadas a partir de 1613, com a inauguração da Universidade de Córdoba, uma das mais antigas do continente americano. De acordo com a Lei de Educação Nacional, este nível de ensino compreende as universidades e institutos universitários públicos e privados, bem como os institutos de

\footnotetext{
${ }^{95}$ Ley de Educación Nacional, art. 19.

${ }^{96}$ Os objetivos da educação inicial argentina estão arrolados no art. 27 da Lei de Educação Nacional.

${ }^{97}$ Ley de Educación Nacional, art. 31.

98 O Conselho Federal de Educação, consoante o artigo 117 da Lei Nacional de Educação, é um "organismo interjurisdiccional, de carácter permanente, como ámbito de concertación, acuerdo y coordinación de la política educativa nacional, asegurando la unidad y articulación del Sistema Educativo Nacional. Estará presidido por el Ministro de Educación, Ciencia y Tecnología e integrado por las autoridades responsables de la conducción educativa de cada jurisdicción y tres (3) representantes del Consejo de Universidades, según lo establecido en la Ley $\mathrm{N}^{\circ} 24.521$ ”.

${ }^{99}$ Ley de Educación Nacional, art. 134. A lei educacional argentina anterior adotava a segunda opção.
} 
educação superior de jurisdição nacional, provincial ou da cidade autônoma de Buenos Aires. ${ }^{100}$ Ademais, este nível de ensino pode ser dividido em educação universitária e nãouniversitária, sendo que as carreiras universitárias duram geralmente 5 ou 6 anos, enquanto as não-universitárias possuem duração menor, entre 3 ou 4 anos.

A lei de educação nacional também prevê, em seu art. 17, o oferecimento de oito modalidades diferentes de ensino, destinados a atender em plenitude as necessidades especiais de determinados segmentos populacionais, objetivando consagrar a igualdade no direito à educação. Estas modalidades são oferecidas dentro dos níveis de ensino mencionados anteriormente, devendo cumprir, pois, os requisitos legais, técnicos e pedagógicos previstos para cada um deles. A seguir, apresentamos as modalidades de ensino previstas no sistema educacional argentino:

\section{Q.6 - Modalidades de Ensino do Sistema Educacional Argentino}

\begin{tabular}{|c|c|c|}
\hline $\begin{array}{c}\text { Modalidade } \\
\text { de Ensino }\end{array}$ & $\begin{array}{l}\text { Previsão } \\
\text { Normativa }\end{array}$ & Descrição \\
\hline $\begin{array}{l}\text { Educación Técnico- } \\
\text { Profesional }\end{array}$ & Art. 38 & $\begin{array}{c}\text { Modalidade de educação secundária ou } \\
\text { superior, responsável pela formação de } \\
\text { técnicos em áreas de ocupação específicas } \\
\text { e de formação profissional. Rege-se pela } \\
\text { lei } 26.058\end{array}$ \\
\hline $\begin{array}{l}\text { Educación } \\
\text { Artística }\end{array}$ & Arts. 39 a 41 & $\begin{array}{l}\text { Presente na educação secundária e } \\
\text { superior, fornecida por escolas específicas. } \\
\text { No ensino secundário, possui } \\
\text { especializações em música, dança, artes } \\
\text { visuais, teatro e artes plásticas. }\end{array}$ \\
\hline $\begin{array}{l}\text { Educación } \\
\text { Especial }\end{array}$ & Arts. 42 a 45 & $\begin{array}{l}\text { Busca garantir o assegurar o direito à } \\
\text { educação das pessoas com deficiências, } \\
\text { transitórias ou permanentes, em todos os } \\
\text { níveis e modalidades do sistema educativo } \\
\text { argentino. Seu oferecimento respalda a } \\
\text { iniciativa de uma educação inclusiva, com } \\
\text { equidade. }\end{array}$ \\
\hline $\begin{array}{c}\text { Educación Permanente de } \\
\text { Jóvenes y Adultos }\end{array}$ & Arts. 46 a 48 & $\begin{array}{l}\text { Destina-se a garantir a alfabetização e o } \\
\text { cumprimento da obrigatoriedade escolar } \\
\text { àqueles que não a tenham completado na } \\
\text { idade estabelecida }\end{array}$ \\
\hline $\begin{array}{l}\text { Educación } \\
\text { Rural }\end{array}$ & Arts. 49 a 51 & $\begin{array}{l}\text { Destina-se a garantir o cumprimento da } \\
\text { escolaridade obrigatória em zonas rurais, } \\
\text { por meio de prestação adequada às }\end{array}$ \\
\hline
\end{tabular}

${ }^{100}$ Ley de Educación Nacional, art. 34. 


\begin{tabular}{|c|c|c|}
\hline & & $\begin{array}{c}\text { necessidades desta população. Presente em } \\
\text { todos os níveis de ensino, excetuando-se o } \\
\text { superior. }\end{array}$ \\
\hline $\begin{array}{c}\text { Educación Intercultural } \\
\text { Bilingüe }\end{array}$ & Arts. 52 a 54 & $\begin{array}{c}\text { Voltada aos povos indígenas, objetiva } \\
\text { cumprir o direito constitucional a uma } \\
\text { educação que favoreça sua identidade } \\
\text { étnica, cultura e língua. Presente em todos } \\
\text { os níveis de ensino, excetuando-se o } \\
\text { superior. }\end{array}$ \\
\hline $\begin{array}{c}\text { Educación en Contextos } \\
\text { Educivación de Libertad }\end{array}$ & Arts. 55 a 59 $59 \begin{array}{c}\text { Tem por objetivo garantir o cumprimento } \\
\text { da oferta de educação às pessoas em } \\
\text { situação de cárcere. Presente em todos os } \\
\text { níveis educacionais. }\end{array}$ \\
\hline $\begin{array}{c}\text { Hospitalaria } \\
\text { Arts. } 60 \text { e 61 } 61\end{array}$ & $\begin{array}{c}\text { Modalidade que assegura o direito à } \\
\text { educação aos alunos, que por razão de } \\
\text { saúde, não possam comparecer } \\
\text { regularmente às instituições de ensino por } \\
\text { mais de 30 dias. Presente em todos os } \\
\text { níveis de ensino, excetuando-se o superior. }\end{array}$ \\
\hline
\end{tabular}

A legislação ainda concede a faculdade de criação de outras modalidades de educação às jurisidições educacionais, quando houver necessidades específicas de caráter permanente ou contextual que o justifiquem. ${ }^{101}$

\section{$\underline{1.4 .2-\text { Brasil }}$}

$\mathrm{O}$ arcabouço institucional do sistema educacional brasileiro encontra-se delineado na Lei de Diretrizes e Bases da Educação - LDB (Lei n. 9.394/96), no Plano Nacional de Educação - PNE (aprovado pela Lei n. 10.172/01) e na Constituição Federal de 1988, que tratou longamente acerca do tema. Destacam-se, no plano constitucional, as modificações introduzidas pelas Emendas Constitucionais 14/96, 53/06 e 59/09, as quais alteraram radicalmente a educação básica no país.

Atualmente, a estrutura do sistema educacional brasileiro apresenta a seguinte face:

${ }^{101}$ Ley de Educación Nacional, art. 17. 
Q.7 - Estrutura do Sistema Educacional Brasileiro

\begin{tabular}{|c|c|c|}
\hline Nível de Ensino & Ciclos & Idade dos Alunos \\
\hline \multirow{2}{*}{$\begin{array}{c}\text { Cine } 00 \\
\text { Educação Infantil }\end{array}$} & Creche & até 03 anos \\
\hline & Pré-escola & 03 a 05 anos \\
\hline $\begin{array}{c}\text { Cine } 01 \text { e } 02 \\
\text { Ensino Fundamental }\end{array}$ & $\begin{array}{c}\text { A critério das instituições } \\
\text { de ensino }\end{array}$ & 06 a 14 anos \\
\hline $\begin{array}{l}\text { Cine } 03 \\
\text { Ensino Médio }\end{array}$ & - & 15 a 17 anos \\
\hline \multirow{2}{*}{$\begin{array}{c}\text { Cine } 05 \text { e } 06 \\
\text { Educação Superior }\end{array}$} & Universitário & \multirow{2}{*}{ a partir de 18 anos } \\
\hline & Não-Universitário & \\
\hline
\end{tabular}

A educação escolar brasileira, pelo art. 21 da LDB, é composta por dois níveis escolares: educação básica e o ensino superior. Contudo, a educação básica subdivide-se, ainda, em três etapas, identificadas pelos níveis de ensino: educação infantil, ensino fundamental e ensino médio. Como finalidades específicas da educação básica, citamos: a) fornecer ao aluno a formação comum indispensável para o exercício da cidadania; e, b) fornecer-lhes meios para progredir no trabalho e em estudos posteriores. ${ }^{102}$

A educação infantil, primeira etapa da educação básica, é oferecida em creches, para crianças de até três anos de idade e em pré-escolas, para crianças entre quatro e cinco anos. A legislação, por sua vez, reforça a importância da família e comunidade, entendendo ser a atuação do Estado complementar à educação promovida por estes entes. ${ }^{103}$ Neste nível de ensino, destaca-se a discussão doutrinária e jurisprudencial empreendida acerca de sua obrigatoriedade, uma vez que não há previsão constitucional explícita sobre sua compulsoriedade. $^{104}$

\footnotetext{
${ }^{102}$ Ver Lei de Diretrizes e Bases da Educação, art. 22.

${ }^{103}$ Ver Lei de Diretrizes e Bases da Educação, art. 29.

${ }^{104}$ Para um estudo aprofundado acerca deste tema, v. ALMEIDA, Marcos Neri de. O Direito à Educação Infantil e a Discricionariedade Administrativa. Dissertação de Mestrado em Direito das Relações Sociais: PUC, 2008.
} 
É forçoso notar, entretanto, que a LDB e o PNE, em sua redação original, faziam menção a uma educação infantil estendida para crianças de até seis anos de idade. Em razão da aprovação da Emenda Constitucional n. ${ }^{\circ}$ 53/2006, alterou-se o art. 208, IV, da Constituição Federal, reduzindo para cinco anos o atendimento de crianças na educação infantil, uma vez que a idade de ingresso obrigatório no ensino fundamental foi reduzida de sete para seis anos.

O ensino fundamental possui duração mínima de nove anos, é obrigatório e gratuito na escola pública, podendo os diferentes sistemas de ensino desdobrá-lo em ciclos. ${ }^{105} \mathrm{De}$ forma a permitir uma aprendizagem inclusiva, posto que o ensino fundamental deva ser ministrado em língua portuguesa, permite-se às comunidades indígenas a utilização de sua língua materna e processos próprios de aprendizagem. ${ }^{106}$ A LDB também prevê a permanência mínima de quatro horas diárias dos educandos nos estabelecimentos de ensino, ressaltando, ainda, a progressiva adoção do magistério em tempo integral. ${ }^{107}$

O ensino médio, etapa final da educação básica, tem duração mínima de três anos e atende a formação geral do educando, complementando os conteúdos ministrados nos níveis de ensino anteriores. Pela redação do art. 36 , § $4^{\circ}$, da LDB, os estabelecimentos de ensino médio poderão incluir programas de preparação geral para o trabalho e, facultativamente, a habilitação profissional. A Emenda Constitucional n. ${ }^{\circ} 14 / 96$ prevê sua progressiva universalização.

A educação superior brasileira abrange quatro tipos de cursos e programas: cursos seqüenciais por campo do saber; curso de graduação abertos aos concluintes do ensino médio; curso de pós-graduação voltado aos educandos graduados, compreendendo programas de mestrado, doutorado e especialização; e, por fim, cursos de extensão, abertos aos candidatos que satisfaçam os requisitos solicitados pelas instituições de ensino. ${ }^{108}$

Em complemento ao ensino regular, a LDB também cuida de outras modalidades de ensino que integram a educação formal, apresentados abaixo:

\footnotetext{
${ }^{105}$ Ver Lei de Diretrizes e Bases da Educação, art. 29, par. $1^{\circ}$.

${ }^{106}$ Ver Lei de Diretrizes e Bases da Educação, art. 29, par. $3^{\circ}$.

${ }^{107}$ Ver Lei de Diretrizes e Bases da Educação, art. 34, par. $2^{\circ}$.

${ }^{108}$ Ver Lei de Diretrizes e Bases da Educação, art. 44.
} 
Q.8 - Modalidades de Ensino na LDB

\begin{tabular}{|c|c|c|}
\hline $\begin{array}{l}\text { Modalidade } \\
\text { de Ensino }\end{array}$ & $\begin{array}{l}\text { Previsão } \\
\text { Normativa }\end{array}$ & Descrição \\
\hline $\begin{array}{c}\text { Educação de Jovens e } \\
\text { Adultos }\end{array}$ & Arts. 37 a 38 & $\begin{array}{l}\text { Destinada àqueles que não tiveram acesso } \\
\text { e continuidade nos estudos do ensino } \\
\text { fundamental e médio na idade adequada }\end{array}$ \\
\hline Educação Profissional & Arts. 39 a 42 & $\begin{array}{c}\text { Ensino integrado às diferentes formas de } \\
\text { educação, trabalho, ciências e tecnologias, } \\
\text { buscando desenvolver aptidões ara a vida } \\
\text { produtiva. }\end{array}$ \\
\hline Educação Especial & Arts. 58 a 60 & $\begin{array}{l}\text { Modalidade oferecida aos educandos } \\
\text { portadores de necessidades especiais que } \\
\text { não possam ser integrados nas classes } \\
\text { comuns do ensino regular. Deve ser } \\
\text { prestada pelo Estado a partir da educação } \\
\text { infantil. }\end{array}$ \\
\hline Educação Indígena & Arts. 78 e 79 & $\begin{array}{l}\text { Voltada aos povos indígenas, objetiva } \\
\text { cumprir o direito constitucional a uma } \\
\text { educação cultural bilíngüe, respeitando-se } \\
\text { a identidade étnica, cultura e língua dos } \\
\text { educandos. }\end{array}$ \\
\hline
\end{tabular}

\section{$\underline{1.4 .3 ~-~ P a r a g u a i ~}$}

A educação no Paraguai passou por diversas transformações e reformas. Posto que o Estado paraguaio tenha conseguido alcançar altos índices educacionais no século XIX, podese dizer que o século seguinte a educação paraguaia foi vitimada por uma piora sistêmica em todos os seus indicadores. O atual modelo de educação no país conheceu seus primeiros contornos após a promulgação da nova constituição, em 1992. Dentro de um processo de reestruturação, iniciou-se, a partir do ano 1994, a implementação da Reforma Educativa, cuja prioridade é a de melhorar a qualidade e pertinência da educação, garantido a igualdade de oportunidades para todos. 
Hodiernamente, o sistema educacional paraguaio tem como marco legal a Lei Geral de Educação, promulgada em 26 de maio de 1998. Este diploma, à semelhança de suas contrapartes regionais, estabelece a responsabilidade estatal em "asegurar a todo la población del país el acceso a la educación y crear las condiciones de una real igualdad de oportunidades". ${ }^{109}$ Além disso, o referido documento define os objetivos do sistema educacional paraguaio, reconhecendo-se a importância do desenvolvimento humano em todas as suas dimensões, o preparo para o mercado de trabalho e o aprendizado das duas línguas oficiais do país. $^{110}$

Assim como também ocorre em outros sistemas educacionais da região, o Paraguai prevê uma educação centrada não apenas na igualdade de condições ao acesso à educação como também no respeito às diferentes identidades culturais. ${ }^{111}$ Outrossim, ressalta a importância da qualidade educacional, contudo, não a define, limitando-se apenas a prever a utilização de mecanismos de avaliação sistemáticas e permanentes de instituições educacionais, docentes e alunos. ${ }^{112}$

O Ministério da Educação e Cultura (MEC), por força do artigo 89 da Lei Geral de Educação, governa, organiza e administra o Sistema Educativo Nacional, em coordenação com os governos departamentais e municipais. Há também a previsão da adoção de uma política de favorecimento à descentralização dos serviços educacionais em favor das autoridades de âmbito local. ${ }^{113} \mathrm{Em}$ suas atividades de formulação, execução e avaliação das políticas educacionais, o Ministério de Educação e Cultura é assessorado pelo Conselho Nacional de Educação e Cultura.

Com relação à estrutura do sistema educativo paraguaio inclui a educação de regime geral, a educação de regime especial e outras modalidades de atenção educativa, como a educação permanente de jovens e adultos.

\footnotetext{
${ }^{109}$ Lei Geral de Educação, art. $4^{\text {o }}$.

${ }^{110}$ Os objetivos do sistema educacional paraguaio estão apresentados no artigo $9^{\circ}$ da Lei Geral de Educação.

${ }^{111}$ Sobre os princípios da educação paraguaia, ver art. 10 da referida lei de educação.

112 Lei Geral de Educação, arts. 20 a 22.

${ }^{113}$ Lei Geral de Educação, art. 90, "b”.
} 
Dentro do regime geral, a educação formal paraguaia, ${ }^{114}$ diferentemente dos outros países da região, estrutura-se em três níveis distintos de ensino, sendo que o primeiro corresponderia à educação inicial e à educação escolar básica. Apresentamos, a seguir, a estrutura prevista no art. 27 da Lei Geral de Educação:

\section{Q.9 - Estrutura do Sistema Educacional Paraguaio}

\begin{tabular}{|c|c|c|}
\hline Nível de Ensino & Ciclo & Idade dos Alunos \\
\hline \multirow{3}{*}{$\begin{array}{c}\text { Cine } 00 \\
\text { (Educación Inicial) }\end{array}$} & Jardin Maternal & 0 a 03 anos \\
\hline & Jardín de Infantes & 03 a 04 anos \\
\hline & Preescolar & 05 anos \\
\hline \multirow{3}{*}{$\begin{array}{c}\text { Cines } 01 \text { e } 02 \\
\text { (Educación Escolar Básica) }\end{array}$} & Primer Ciclo & 06 a 08 anos \\
\hline & Segundo Ciclo & 09 a 11 anos \\
\hline & Tercer Ciclo & 12 a 14 anos \\
\hline \multirow{2}{*}{$\begin{array}{c}\text { Cine } 03 \\
\text { (Educación Media) }\end{array}$} & Bachillerato Científico & \multirow{2}{*}{14 a 17 anos } \\
\hline & Bachillerato Técnico & \\
\hline \multirow{2}{*}{$\begin{array}{c}\text { Cine } 05 \text { e } 06 \\
\text { (Educación Superior) }\end{array}$} & Universitário & \multirow{2}{*}{ a partir de 18 ano } \\
\hline & Não-Universitário & \\
\hline
\end{tabular}

A educação inicial no Paraguai compreende três ciclos não obrigatórios. Todavia, o art. 29 da Lei Geral de Educação adianta que o ciclo pré-escolar, após aprovação parlamentar de decreto do Poder Executivo de iniciativa do Ministério de Educação e Cultura, pertencerá ao nível da educação escolar básica, passando a ser de caráter obrigatório. ${ }^{115}$ A lei ainda

\footnotetext{
${ }^{114}$ Dentro do âmbito da educação de regime geral, prevê-se ainda a existência da educação não formal, definido como "aquélla que se ofrece con el objeto de complementar, suplir conocimientos, actualizar y formar en aspectos académicos o laborales, sin las exigencias de las formalidades de la educación escolarizada ni la sujeción al sistema de niveles, ciclos y grados, establecidos por el sistema educativo nacional" (art.11, "g", da Lei Geral de Educação). A legislação paraguaia ainda inova ao reconhecer a existência da chamada educação reflexa, definida como "aquella que procede de personas, entidades, medios de comunicación social, medios impresos, tradiciones, costumbres, ambientes sociales, comportamientos sociales y otros no estructurados, que producen aprendizajes y conocimientos libres y espontáneamente adquiridos" (art. 11, "h", da Lei Geral de Educação).

${ }^{115}$ Até o presente momento não ocorreu tal aprovação.
} 
estipula o ensino das duas línguas oficiais do país a partir deste nível, com a prevalência da língua materna do educando.

A educação escolar básica, conforme mencionamos, também corresponde ao primeiro nível educacional no sistema paraguaio. Contudo, diferentemente da educação inicial, trata-se de ciclo de freqüência obrigatória ao longo de seus nove graus, divididos em três ciclos de três anos cada. A lei ainda prevê sua gratuidade nas escolas de gestão oficial. ${ }^{116}$

A educação média paraguaia possui duas modalidades: o bacharelado e a formação profissional média. Ambas são compostas de um único ciclo com três anos de duração. Na modalidade do bacharelado, existe ainda a opção entre o Bacharelado Científico (com ênfase em Letras e Artes; em Ciências Sociais; ou em Ciências Básicas e Tecnologia) e Bacharelado Técnico (com ênfase na área industrial, serviços ou ainda agropecuária). A lei não menciona expressamente a gratuidade neste nível de ensino, limitando-se apenas a mencionar que o Estado fomentará o acesso à educação média, prevendo os recursos necessários para tanto. ${ }^{117}$

A educação superior, por sua vez, é exercida por meio das universidades, institutos superiores e instituições de formação profissional, de acordo com o artigo 47 da Lei Geral de Educação, a qual ainda prevê os graus universitários, pós-universitários e não-universitários. Ressalta-se que as universidades públicas e privadas e as instituições superiores de ensino são parte do sistema educativo e possuem autonomia em sua gestão. ${ }^{118}$

A Lei Geral de Educação paraguaia prevê ainda duas modalidades de ensino dentro do regime de educação especial: a educação artística e o ensino de línguas estrangeiras, estabelecendo para ambas os critérios para homologação, ministério e titulação. Já as modalidades de atenção educacional tratam de garantir o acesso de pessoas com algum tipo de dificuldade em se integrar plenamente ao sistema educativo educacional, conforme poderemos ver a seguir:

\footnotetext{
${ }^{116}$ Lei Geral de Educação, art. 34.

${ }^{117}$ Lei Geral de Educação, art. 38.

${ }^{118}$ Lei Geral de Educação, art. 53.
} 
Q.10 - Modalidades de Atenção Educacional no Sistema Paraguaio

\begin{tabular}{|c|c|c|}
\hline $\begin{array}{l}\text { Modalidade } \\
\text { de Ensino }\end{array}$ & $\begin{array}{l}\text { Previsão } \\
\text { Normativa }\end{array}$ & Descrição \\
\hline $\begin{array}{l}\text { Educación General Básica } \\
\text { y Educación Permanente }\end{array}$ & Art. 76 & $\begin{array}{l}\text { Destina-se a erradicar o analfabetismo e } \\
\text { fornecer aos educandos conhecimentos e } \\
\text { valores básicos para a vida em } \\
\text { comunidade. Também busca garantir o } \\
\text { acesso dos alunos no sistema carcerário. }\end{array}$ \\
\hline $\begin{array}{c}\text { Educación } \\
\text { para Grupos Étnicos }\end{array}$ & Arts. 77 e 78 & $\begin{array}{c}\text { Possui a finalidade de garantir o acesso a } \\
\text { uma educação que promova e respeite as } \\
\text { identidades culturais em prol da integração } \\
\text { social paraguaia }\end{array}$ \\
\hline $\begin{array}{c}\text { Educación } \\
\text { Campesina y Rural }\end{array}$ & Art. 79 & $\begin{array}{l}\text { Seu objetivo é garantir uma melhoria na } \\
\text { qualidade de vida dos educandos e suas } \\
\text { famílias no meio rural, favorecendo-se o } \\
\text { ensino de técnicas de produção que o ajude } \\
\text { em seu sustento }\end{array}$ \\
\hline $\begin{array}{l}\text { Educación } \\
\text { para Personas con } \\
\text { Limitaciones o con } \\
\text { Capacidades } \\
\text { Excepcionales }\end{array}$ & Arts. 80 a 84 & $\begin{array}{l}\text { Procura atender pessoas com } \\
\text { características individuais } \\
\text { significativamente diferentes de seus pares, } \\
\text { bem como aquelas com necessidades } \\
\text { educacionais especiais. Insere-se dentro de } \\
\text { uma perspectiva inclusiva de educação. }\end{array}$ \\
\hline $\begin{array}{l}\text { Educación para la } \\
\text { Rehabilitación Social y } \\
\text { Prevención de Adicciones }\end{array}$ & Arts. 85 e 86 & $\begin{array}{c}\text { Modalidade destinada a informar os grupos } \\
\text { de risco a respeito do uso de drogas, bem } \\
\text { como servir à reabilitação social de pessoas } \\
\text { com vícios }\end{array}$ \\
\hline $\begin{array}{l}\text { Educación Militar y } \\
\text { Educación Policial }\end{array}$ & Art. 87 & $\begin{array}{c}\text { Modalidade que reconhece a educação } \\
\text { fornecida aos militares e policiais, } \\
\text { seguindo normas específicas }\end{array}$ \\
\hline $\begin{array}{c}\text { Educación para Ministros } \\
\text { de Culto }\end{array}$ & Art. 88 & $\begin{array}{l}\text { Modalidade que reconhece a educação } \\
\text { fornecida para ministros de cultos nas } \\
\text { igrejas e comunidades religiosas. }\end{array}$ \\
\hline
\end{tabular}

Repetindo a CP, a Lei Geral da Educação, determina que o orçamento destinado à educação paraguaia não poderá, em nenhum caso, ser menor que 20\% do Orçamento Geral de Gastos da Nação, montante este a ser destinado ao financiamento do Ministério da Educação e Cultura e Conselho Nacional de Educação e Cultura, bem como de suas atividades; funcionamento, equipagem e manutenção dos estabelecimentos educacionais públicos; criação de novas instituições educacionais públicas; financiamento de instituições 
educacionais privadas que prestem serviços de educação básica a pessoas ou comunidades com necessidades insatisfeitas etc. ${ }^{119}$

\subsection{4 - Uruguai}

Assim como o ocorrido na Argentina, a República Oriental do Uruguai assegurou precocemente a educação primária universal, obrigatória e gratuita, ainda no século XIX. A primeira legislação específica sobre a educação foi promulgada em 1877, sob o governo do presidente José Pedro Varela. A sua primeira estrutura comportava os níveis de educação primária, secundária e superior, as quais ganharam, ao longo do tempo, significativa autonomia administrativa e orçamentária.

O diploma legal atual do país sobre a Educação é a Ley General de Educación n. 18.437, datada de 12.12.2008, revogando normativa anterior de promulgação relativamente recente. ${ }^{120}$ Em seu artigo $1^{\circ}$, a referida norma estabelece o reconhecimento da educação como direito humano fundamental, obrigando-se o Estado à prestação de uma educação com qualidade para todos os cidadãos, ao longo de toda a vida.

Ademais, à semelhança das outras constituições da região, apregoa uma educação que atenda à totalidade das pessoas, prescindindo de toda e qualquer forma de discriminação, por força do art. $2^{\circ}$ da referida lei. Neste intuito, também se determina a obrigação do Estado uruguaio em assegurar a prestação dos serviços educacionais às coletividades minoritárias e em especial situação de vulnerabilidade, de modo a permitir a igualdade de oportunidades e sua efetiva inclusão social. ${ }^{121}$

É importante mencionar que a lei educacional uruguaia reconhece explicitamente a incorporação dos direitos humanos, consagrados na constituição nacional e nos instrumentos internacionais ratificados pelo país, como marco de referência fundamental e elementos

\footnotetext{
${ }^{119}$ Ver Lei Geral de Educação, arts. 145 e 149.

${ }^{120}$ Tratava-se da Lei n. 16.736, datada de 05.01.1996.

${ }^{121}$ Ver Lei Geral de Educação, art. $8^{\circ}$.
} 
essenciais das propostas, programas e ações educativas. ${ }^{122}$ Ressalta-se, assim, a deferência realizada aos tratados internacionais de direitos humanos e seu impacto na educação uruguaia.

A obrigatoriedade na educação uruguaia foi radicalmente estendida pela nova legislação educacional. Pela norma anterior, a obrigatoriedade resumia-se a um período de 10 anos, compreendido entre o último ano da educação inicial até o fim do ciclo básico da educação média. Atualmente, por força do art. $7^{\circ}$ do dispositivo legal em vigor, as crianças uruguaias devem obrigatoriamente comparecer às aulas a partir dos quatro anos de idade até o final da educação média superior, última etapa antes da educação superior.

A gratuidade, por sua vez, é princípio da Educação Pública Estatal, assim como a laicidade e a equidade. ${ }^{123}$ Estende-se, portanto, a todos os níveis de ensino na estrutura educacional uruguaia, abrangendo, inclusive, a educação superior oferecida pelo Estado uruguaio. $^{124}$

A preocupação com a qualidade do ensino oferecido pelas instituições de ensino uruguaias incentivou a criação do Instituto Nacional de Avaliação Educacional, pessoa jurídica de direito público não-estatal, vinculado ao Poder Executivo através do Ministério de Educação e Cultura. Sua função precípua é de fornecer dados e indicadores acerca do estado atual do ensino uruguaio, bem como avaliar os níveis de ensino inicial, primário e médio, tendo como referências os seguintes critérios:

\begin{abstract}
“a) La coherencia entre los currículos y recursos educativos, con las orientaciones, principios y fines de la educación establecidos en la presente ley; b) La calidad de la formación y el desarrollo profesional de los docente; c) La adecuación de los procesos educativos de cada nivel a las características, necesidades e intereses de los educandos y su pertinencia en relación a los ejes transversales del Sistema Nacional de Educación establecidos por la presente ley; d) La eficiencia de la administración de los recursos humanos y materiales disponibles; e, e) Las condiciones edilicias, equipamiento y mantenimiento de los centros educativos.
\end{abstract}

Com relação à estrutura do sistema nacional de educação uruguaio, destaca-se a atividade da Administração Nacional de Educação Pública (ANEP), ente autônomo com

\footnotetext{
${ }^{122}$ Ver Lei Geral de Educação, art.4 ${ }^{\circ}$.

${ }^{123}$ Ver Lei Geral de Educação, arts. 15 a 18.

${ }^{124}$ O Estado uruguaio oferece gratuitamente, em nível de educação superior, cursos na Universidade da República, em Institutos de Formação Docente, Escolas Militares e Escola Nacional de Polícia.
} 
personalidade jurídica, responsável por elaborar e desenvolver políticas educacionais específicas e inclusivas nos diferentes níveis de ensino, de acordo com os princípios e orientações gerais dispostos na Lei Geral de Educação. ${ }^{125} \mathrm{Na}$ consecução de seus objetivos, conta com as atividades empreendidas pelo Conselho Diretivo Central e os Conselhos específicos para cada nível de ensino uruguaio. ${ }^{126}$

O cumprimento dos fins e objetivos da lei educacional uruguaia e a planificação da educação pública, entretanto, são resguardados pela Comissão Coordenadora do Sistema Nacional de Educação Pública, instituída pelo artigo 106 e seguintes, no âmbito do Ministério de Educação e Cultura uruguaio.

Como forma de promover a participação da sociedade no debate educacional, a atual Lei de Educação criou, por meio do artigo 42, a Comissão Nacional de Educação, órgão de caráter consultivo que se constitui num âmbito de deliberação sobre políticas educativas, contando com representantes de todos os segmentos da educação pública e privada, além de representantes da sociedade civil. ${ }^{127}$

Diferentemente dos níveis de educação formal estudados anteriormente, a atual legislação educacional uruguaia não ostenta ciclos dentro de seus níveis de ensino. Apresentamos, a seguir, a estrutura atual do ensino formal no sistema educacional uruguaio, prevista no art. 22 da Lei Geral de Educação:

\section{Q.11 - Estrutura do Sistema Educacional Uruguaio}

\begin{tabular}{|c|c|}
\hline Nível de Ensino & Idade dos Alunos \\
\hline Cine 00 & 03 a 05 anos \\
\hline
\end{tabular}

\footnotetext{
${ }^{125}$ Ver Lei Geral de Educação, art. 53.

${ }^{126}$ Ver Lei Geral de Educação, arts. 58 a 68.

127 Esta participação também é incentivada pelos Conselhos de Participação, presentes em todos os centros educativos de educação de nível inicial à média superior. Estes órgãos contam com representantes estudantis, docentes, pais e responsáveis, além de membros da comunidade. Consoante o disposto no artigo 77 da Lei Geral de Educação, realizam propostas: “a) Al proyecto educativo que en ejercicio de su responsabilidad profesional elabore la Dirección y el cuerpo docente del centro educativo; b) A la suscripción de acuerdos y convenios con otras instituciones según lo establecido en el artículo 41 de la presente ley; c) A la realización de obras en el centro educativo; d) A la obtención de donaciones y otros recursos extrapresupuestales; e) Al destino de los recursos obtenidos y asignados; f) Al funcionamiento del centro educativo; g) A la realización de actividades sociales y culturales en el centro educativo; e, h) Sobre todo aquello que lo consulte la Dirección del centro educativo".
} 


\begin{tabular}{|c|c|}
\hline & \\
\hline $\begin{array}{c}\text { Cine 01 } \\
(\text { Educación Primaria })\end{array}$ & 06 a 11 anos \\
\hline Cine 02 & 12 a 14 anos \\
\hline$($ Educación Media Básica $)$ & 14 a 17 anos \\
\hline Cine 03 & a partir de 18 anos \\
\hline Cducación Media Superior $)$ & \\
\hline Cducación Terciaria $)$ & - \\
\hline Cine 06 & \\
\hline Educación de Postgrado $)$ & \\
\hline
\end{tabular}

Apesar de não estar contemplada no artigo 22, reconhece-se a importância da educação ministrada às crianças entre zero e três anos de idade em capítulo intitulado “educação de primeira infância", previsto no artigo 38, o qual determina a preocupação com a saúde física e mental dos infantes, bem como sua gradual socialização.

A educação inicial no sistema uruguaio está prevista para crianças com idades entre três e cinco anos, com o objetivo de estimular o desenvolvimento afetivo, social, motor e intelectual dos educandos. ${ }^{128}$ Como já mencionamos, destaca-se a sua compulsoriedade para os infantes a partir dos quatro anos de idade. A educação primária, por sua vez, tem como propósito oferecer aos educandos conhecimentos básicos e desenvolver a comunicação e a razão, de forma a estimular a conformação de uma convivência responsável em comunidade. $^{129}$

A educação média no sistema uruguaio possui dois níveis específicos, os quais poderiam ser entendidos como ciclos em outros sistemas educacionais. Em seu ciclo básico, comum a todos os alunos, destina-se a promover o domínio teórico-prático de diferentes disciplinas em todos os campos do conhecimento: artísticas, humanísticas, biológicas, científicas e tecnológicas. Já a educação média superior possui um maior grau de orientação e

\footnotetext{
${ }^{128}$ Ver Lei Geral de Educação, art. 24.

${ }^{129}$ Ver Lei Geral de Educação, art. 25.
} 
especialização, a partir da identificação de três modalidades: (a) bacharelados gerais, (b) bacharelado tecnológico; e (c) formação técnica e profissional, voltada especialmente para a inserção no mercado laboral. As três modalidades acima permitem aos alunos a continuidade educativa, por meio do acesso à educação superior. ${ }^{130}$

A educação denominada terciária ou superior se divide em superior universitário e superior não-universitário. A primeira modalidade compreende o ensino oferecido pelas instituições universitárias do país, que são em total de seis, sendo cinco privadas e uma pública: a Universidade da República, de ensino gratuito. Em sua modalidade nãouniversitária, contempla-se o ensino oferecido pelos Institutos de Formação Docente; Centro de Desenho Industrial na órbita do Ministério da Educação e Cultura; Escola Militar, Escola Naval e Escola Militar de Aeronáutica na órbita do Ministério da Defesa; Escola Nacional de Polícia no âmbito do Ministério do Interior; e, Institutos Privados. ${ }^{131}$

Há, ainda, a previsão do nível educacional de pós-graduação, correspondente aos estudos realizados posteriormente à obtenção de grau universitário ou licenciatura, nas modalidades de especialização, mestrado ou doutorado. ${ }^{132}$

Com relação às modalidades de ensino formal, a legislação uruguaia é bastante lacônica, prevendo sucintamente que a educação formal também buscará garantir a igualdade no exercício do direito à educação, atendendo às particularidades de indivíduos ou grupos, de caráter permanente ou temporal. Neste diapasão, destaca o artigo 33 a educação rural, a educação de pessoas jovens e adultas e a educação para pessoas com capacidades excepcionais, prevendo que o objetivo destas modalidades deve ser o fornecimento da educação obrigatória, de acordo com as peculiaridades que envolvem o ensino nestes casos.

Outra diferença significativa da legislação educacional uruguaia para suas contrapartes regionais está na ausência de uma previsão orçamentária específica para a educação.

\footnotetext{
${ }^{130}$ Ver Lei Geral de Educação, arts. 26 e 27.

${ }^{131}$ Ver MERCOSUL. Vitrina Estadística 2007, p. 19.

${ }^{132}$ Ver Lei Geral de Educação, art. 32.
} 


\section{$\underline{1.4 .5-\text { Quadro Comparativo }}$}

Apresentamos abaixo um quadro comparativo dos sistemas educacionais nacionais dos membros nos países estudados. A estrutura do quadro se encontra na Vitrina Estadística do MERCOSUR 2007, ${ }^{133}$ publicação à qual já nos referimos neste trabalho. Se a estrutura é a mesma, não podemos dizer o mesmo de seu conteúdo, uma vez que realizamos todas as alterações importadas pelas mais recentes modificações legislativas, como a Emenda Constitucional 59/09 no Brasil e a nova lei educacional uruguaia. Estes dois diplomas jurídicos estenderam radicalmente a obrigatoriedade do ensino em seus respectivos sistemas educacionais.

\section{Q. 12 - Quadro Comparativo entre os Sistemas de Ensino}

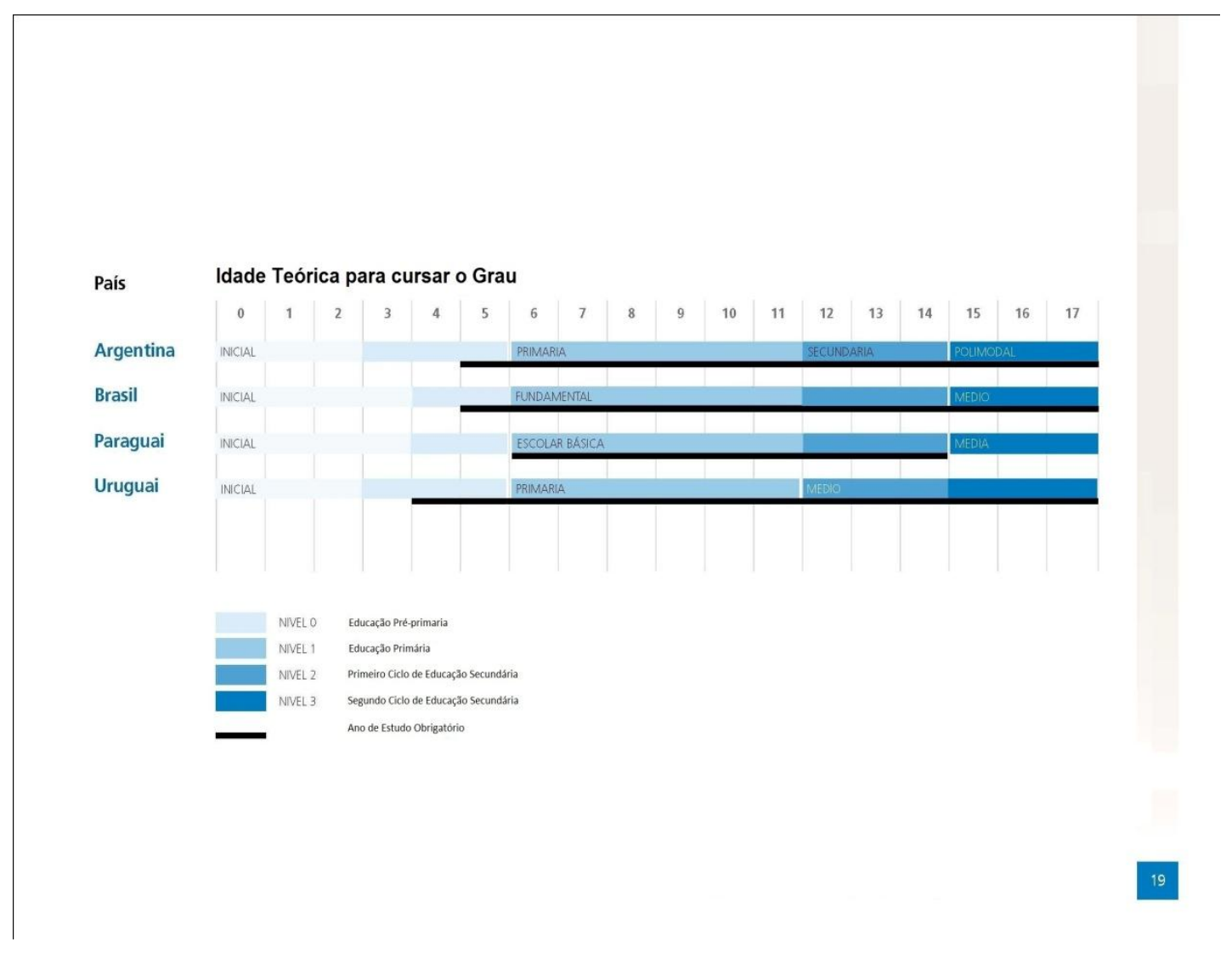

\footnotetext{
${ }^{133}$ Disponível em:

http://www.sic.inep.gov.br/index.php?option=com_docman\&task=cat_view\&gid=98\&Itemid=32. Acesso em 23 de janeiro de 2010.
} 


\section{5 - O Esquema D+3A ${ }^{134}$ no Plano Constitucional}

Conforme já enunciamos na introdução, procederemos à análise do conteúdo do direito à educação básica previsto no plano constitucional, a partir da classificação empregada por Katarina Tomasevski. ${ }^{135}$ A metodologia proposta oferece a categorização dos conteúdos do direito à educação em quatro qualidades, estruturadas em torno de uma educação disponível, acessível, aceitável e adaptável.

Realizamos, a seguir, a classificação dos conteúdos dos direitos educacionais previstos nas Constituições dos países ora estudados, focando apenas o nível educacional básico, de acordo com a metodologia sugerida. Note-se que alguns conteúdos podem estar em mais de um quadro. Chegamos, assim, aos seguintes dados:

\section{Q.13 - Disponibilidade}

\begin{tabular}{|c|c|c|}
\hline País & Em Relação a Escolas & Em Relação a Professores \\
\hline Argentina & $\begin{array}{l}\text { - Discriminação de competências da educação primária } \\
\text { (CA, art. } 5^{\circ} ; \text { art. } 75 \text {, inciso } 19 ; \text { art. 125) } \\
\text { - Liberdade de ensino para a iniciativa privada (CA, } \\
\text { art. 14) }\end{array}$ & 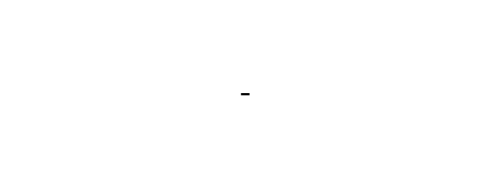 \\
\hline Brasil & $\begin{array}{l}\text { - A educação é um direito social }\left(\mathrm{CB}, \text { art. } 6^{\circ}\right) \\
\text { - Direito de todos e dever do Estado (CB, art. 205) } \\
\text { - Coexistência de escolas públicas e privadas (CB, art. } \\
\text { 206, III) } \\
\text { - Gratuidade do ensino público (CB, art. 206, IV) } \\
\text { - Liberdade de ensino para a iniciativa privada, } \\
\text { atendidas as normas gerais de educação (CB, art. } 209 \text { e } \\
\text { inciso I) } \\
\text { - Autorização e avaliação de qualidade das instituições } \\
\text { de ensino privadas (CB, art. 209, II) } \\
\text { - Organização federativa dos sistemas de ensino, em } \\
\text { regime de colaboração (CB, art. 211) } \\
\text { - Discriminação de competências de ensino para os } \\
\text { entes da federação (CB, art. 212) } \\
\text { - Fixação de percentuais mínimos de aplicação da } \\
\text { receita resultante de impostos na manutenção e } \\
\text { desenvolvimento do ensino (CB, art. 212) } \\
\text { - Fonte adicional de financiamento pela contribuição } \\
\text { social do salário-educação recolhido pelas empresas }\end{array}$ & $\begin{array}{l}\text { - Liberdade acadêmica (CB, art. } \\
\text { 206, II e III) } \\
\text { - Planos de carreira e ingresso por } \\
\text { concurso (CB, art. 206, V) } \\
\text { - Piso salarial nacional para os } \\
\text { profissionais da educação pública } \\
\text { (CB, art. 206, VIII) } \\
\text { - Gestão democrática do ensino } \\
\text { público (CB, art. 206, VI) } \\
\text { - Melhoria das condições de } \\
\text { trabalho por via de recursos do } \\
\text { FUNDEB (ADCT, art. 60) } \\
\text { - Regime geral das liberdades } \\
\text { (CB, art. } 5^{\circ} \text {, IX, XIII, XVII e XX) } \\
\text { - Aposentadoria especial para o } \\
\text { magistério na educação básica }\end{array}$ \\
\hline
\end{tabular}

134 Empregamos aqui a nomenclatura traduzida na obra de Nina Ranieri, em RANIERI, Nina. O Estado Democrático de Direito. op. cit.pp. 311-314.

135 TOMASEVSKI, Katarina. Human Rights Obligations: making education available, accessible, acceptable and adaptable. Gotemburgo: Novum Grafiska AB, 2001. 


\begin{tabular}{|c|c|c|}
\hline & $\begin{array}{l}\left.\text { (CB, art. } 212, \S 5^{\circ}\right) \\
\text { - Destinação de recursos a escolas comunitárias, } \\
\text { confessionais ou filantrópicas (CB, art. 213) } \\
\text { - Destinação prioritária de recursos para a educação } \\
\text { básica, por intermédio do FUNDEB (ADCT, art. 60) }\end{array}$ & $\left(\mathrm{CB}\right.$, art. $\left.40, \S 5^{\circ}\right)$ \\
\hline Paraguai & $\begin{array}{l}\text { - Direito à educação integral e permanente (CP, art. 73) } \\
\text { - Liberdade de ensino para a iniciativa privada (CP, art. } \\
\text { 74) } \\
\text { - Organização do sistema educacional pelo Estado, } \\
\text { com a participação das comunidades educativas (CP, } \\
\text { art. 76) } \\
\text { - Fixação de percentual mínimo de financiamento da } \\
\text { educação (CP, art. 85) } \\
\text { - Discriminação de competências de ensino para os } \\
\text { entes da administração pública (CP, arts. } 163 \text { e 168) }\end{array}$ & - \\
\hline Uruguai & $\begin{array}{l}\text { - Liberdade de ensino para a iniciativa privada (CU, } \\
\text { art. 68) } \\
\text { - Exoneração de impostos nacionais e municipais dos } \\
\text { estabelecimentos de ensino privados (CU, art. 69) } \\
\text { - Organização do sistema de ensino (CU, art. 202) }\end{array}$ & - \\
\hline
\end{tabular}

\section{Q.14 - Acessibilidade}

\section{País} Ensino Obrigatório

Ensino Não-Obrigatório

\begin{tabular}{|c|c|c|}
\hline Argentina & $\begin{array}{l}\text { - Responsabilidade indelegável do Estado na sua } \\
\text { prestação (CA, art. 75, inciso 19) } \\
\text { - Participação da família e sociedade (CA, art. 75, } \\
\text { inciso 19) } \\
\text { - Gratuidade e equidade do ensino público (CA, art. } \\
75, \text { inciso 19) }\end{array}$ & - \\
\hline Brasil & $\begin{array}{l}\text { - Absoluta prioridade da criança ao direito à educação } \\
\qquad \text { (CB, art. 227) } \\
\text { - Educação básica obrigatória e gratuita (CB, art. 206, } \\
\left.\text { IV; art. 208, I e } \S \S 1^{\circ} 2^{\circ}\right) \\
\text { - Educação infantil em creches e pré-escolas (CB, art. } \\
\text { - Oferta de ensino noturno }(\mathrm{CB}, \text { art. 208, VI) } \\
\text { - Responsabilização do Poder Público pela oferta } \\
\left.\text { irregular do ensino obrigatório (CB, art. } 208 \S 2^{\circ}\right) \\
\text { - Recenseamento dos alunos do ensino fundamental } \\
\text { obrigatório e gratuito como obrigação do Poder } \\
\left.\text { Público (CB, art. 208, } \S 3^{\circ}\right) \\
\text { - Responsabilização dos pais ou responsáveis pela } \\
\text { freqüência à escola, no ensino obrigatório (CB, art. } \\
\left.208, \S 3^{\circ}\right) \text {, e dever geral de assistência (CB, arts. } 227 \text { e } \\
\quad 229) \\
\text { - Responsabilização da sociedade pelo direito à } \\
\text { educação (CB, art. 227) } \\
\text { - Proibição de admissão do menor ao trabalho até }\end{array}$ & $\begin{array}{c}\text { - Educação infantil em creches e } \\
\text { pré-escolas (CB, art. 208, IV) }\end{array}$ \\
\hline
\end{tabular}




\begin{tabular}{|c|c|c|}
\hline & quatorze anos (CB, art. $\left.227, \S 3^{\circ}\right)$ & \\
\hline Paraguai & $\begin{array}{l}\text { - Responsabilização dos pais e sociedade na realização } \\
\text { do direito à educação }(\mathrm{CP}, \text { art. } 75) \\
\text { - Obrigatoriedade da educação básica }(\mathrm{CP}, \text { art. } 76) \\
\text { - Gratuidade do ensino público }(\mathrm{CP}, \text { art. } 76)\end{array}$ & - \\
\hline Uruguai & $\begin{array}{l}\text { - Participação e responsabilização dos pais na } \\
\text { realização do direito à educação (CU, art. } 41 \text { e art. 68) } \\
\text { - Obrigatoriedade da educação básica (CU, art. 70) } \\
\text { - Gratuidade do ensino público (CU, art. 71) }\end{array}$ & - \\
\hline
\end{tabular}

\section{Q.15 - Admissibilidade}

\begin{tabular}{|c|c|}
\hline País & Regulação e Supervisão \\
\hline Argentina & $\begin{array}{l}\text { - Ensino indígena bilíngüe e intercultural (CA, art. 75, inciso 17) } \\
\text { - Promoção da igualdade de oportunidades e vedação de qualquer forma de discriminação } \\
\text { (CA, art. 75, inc. 19) } \\
\text { - Previsão de assistência à criança em situação de desamparo até o final do ensino primário } \\
\text { (CA, art. 75, inciso 23) }\end{array}$ \\
\hline Brasil & $\begin{array}{l}\text { - Oferta de ensino noturno, adequado às condições do educando }(\mathrm{CB}, \text { art. } 208, \mathrm{VI}) \\
\text { - Programas suplementares de material didático-escolar, transporte, alimentação e } \\
\text { assistência à saúde no ensino obrigatório }(\mathrm{CB}, \text { art. } 208, \mathrm{VII}) \\
\text { - Ensino religioso, de matrícula facultativa }\left(\mathrm{CB}, \text { art. } 210, \S 1^{\circ}\right) \\
\text { - Ensino indígena em língua materna }\left(\mathrm{CB} \text {, art. } 210, \S 2^{\circ}\right) \\
\text { - Reconhecimento dos costumes, línguas e tradições indígenas }(\mathrm{CB} \text {, art. } 231)\end{array}$ \\
\hline Paraguai & $\begin{array}{l}\text { - Ensino indígena respeitador das peculiaridades culturais }(\mathrm{CP}, \text { art. } 66) \\
\text { - Ensino religioso e pluralismo ideológico }(\mathrm{CP}, \text { art. } 74) \\
\text { - Programas suplementares de materiais didáticos e alimentação aos alunos que possuem } \\
\text { recursos escassos }(\mathrm{CP} \text {, art. } 75) \\
\text { - Educação na língua materna do educando }(\mathrm{CP}, \text { art. } 77) \\
\text { - Oferecimento de bolsas de estudo aos alunos que não possuem recursos }(\mathrm{CP}, \text { art. } 80)\end{array}$ \\
\hline Uruguai & $\begin{array}{l}\text { - Previsão de auxílio compensatório às famílias com proles numerosas (CU, art. 41) } \\
\text { - Concessão de bolsas para os alunos do ensino público (CU, art. 71) }\end{array}$ \\
\hline
\end{tabular}

\section{Q.16 - Adequação}

\begin{tabular}{|c|c|}
\hline País & Necessidades Especiais e Educação Não-Escolar \\
\hline Argentina & $\begin{array}{l}\text { - Promoção da igualdade de oportunidades e vedação de qualquer forma de discriminação } \\
\text { (CA, art. 75, inc. 19) }\end{array}$ \\
\hline Brasil & $\begin{array}{l}\text { - Proibição de admissão do menor ao trabalho até quatorze anos }\left(\mathrm{CB} \text {, art. } 227, \S 3^{\circ}\right) \\
\text { - Garantia de acesso do trabalhador adolescente à escola }\left(\mathrm{CB} \text {, art. } 227, \S 3^{\circ}, \mathrm{I}, \mathrm{II}\right)\end{array}$ \\
\hline Paraguai & $\begin{array}{l}\text { - Garantia do direito à educação às pessoas com necessidades especiais }(\mathrm{CP} \text {, art. 58) } \\
\text { - Garantia do direito à educação aos assentamentos campesinos para fins de reforma agrária } \\
(\mathrm{CP}, \text { art. 115, incisos } 4 \mathrm{e} 13)\end{array}$ \\
\hline
\end{tabular}




\section{Uruguai}

Como era de se esperar, a Constituição Brasileira preenche devidamente todos os requisitos previstos pela autora croata. Em decorrência desta ampla constitucionalização da temática educacional, a legislação infraconstitucional muitas vezes se limita a reproduzir os dispositivos da Lei Maior ${ }^{136}$, como sói ocorrer na LDB e no PNE. Nos outros países, contudo, percebemos que o legislador infraconstitucional recebe a importante incumbência de incorporar estes critérios de proteção. A nosso ver, por mais que a eficácia da norma interna atenda ao intuito de tutela destes direitos, o fato de não constarem expressamente de um rol constitucional enfraquece a proteção jurídica dispensada.

É oportuno esclarecer que utilizamos apenas o texto constitucional primário argentino, sem nos valer das normas internacionais introduzidas por meio da equiparação constitucional prevista no artigo 75, inciso 24 desta Carta Magna. A esse respeito Katarina Tomasevski diz:

\footnotetext{
"In countries where international human right treaties are directly applicable, the absence of explicit domestic human rights guarantees is legally irrelevant. Quite a few countries that have constitutions which are more than hundred years old, do not even mention the word 'human rights', and direct application of international human rights treaties supplements lacking constitutional guarantees. Making international human rights law directly applicable is the model best suited to ensuring the universality of human rights". ${ }^{13}$
}

Vejamos, no próximo capítulo, quais são essas normas internacionais e como elas se integram nos ordenamentos nacionais mercosulinos.

\footnotetext{
${ }^{136}$ RANIERI, Nina. op. cit. p. 320.

${ }^{137}$ TOMASEVSKI, Katarina, Free and Compulsory Education for All Children: the gap between promise and performance. Gotemburgo: Novum Grafiska AB, 2001. p. 13. Em tradução livre: "Nos países onde os tratados internacionais de direitos humanos são diretamente aplicáveis, a ausência de garantias explícitas de direitos humanos domésticos é legalmente irrelevante. Alguns países que possuem Constituições centenárias nem mesmo mencionam a palavra 'direitos humanos' e a aplicação direta dos tratados internacionais de direitos humanos suplementa a falta de garantias constitucionais. Tornar o Direito Internacional dos Direitos Humanos diretamente aplicável é o melhor modelo para assegurar a universalidade dos direitos humanos".
} 


\section{CAPÍtUlO 2 - 0 DIREITO À EDUCAÇÃO BÁSICA NO PLANO INTERNACIONAL}

Este capítulo apreenderá a extensão da proteção normativa internacional do direito à educação básica. Procuraremos cuidar, num primeiro momento, do fenômeno da universalização dos direitos humanos, com repercussões políticas e jurídicas nos planos globais e continentais. A seguir, apresentaremos a conceito de tratado internacional e as suas principais características, para então iniciar a discussão a respeito das relações entre o Direito Internacional Público e o Direito Interno, de modo a explicitar a real relevância e a abrangência das normas oriundas dos tratados internacionais perante os ordenamentos nacionais dos Estados-membros do MERCOSUL. Estaremos atentos às deferências normativas concedidas aos tratados de direitos humanos, cuja integração aos ordenamentos nacionais tem merecido atenção cuidadosa do poder constituinte derivado MERCOSULino. E, feito isso, apresentaremos os tratados que versam sobre o Direito à Educação Básica, bem como as principais declarações internacionais no sentido de sua defesa e promoção.

\section{1 - A Internacionalização dos Direitos Humanos}

Como já vimos em capítulo anterior, o constitucionalismo do final do século XVIII, arrimado nas Declarações de Direito originadas no contexto das revoluções liberais, deu ensejo a identificação de um rol de direitos individuais considerados inerentes à condição humana. Nesta condição, é evidente que os direitos fundamentais nascem com pretensões universalistas, vez que se calcavam no gênero humano.

Contudo, uma vez que os direitos fundamentais surgiram no contexto de afirmação do Estado-nação, paradoxalmente a tutela destes direitos acabou sendo relegada ao plano nacional, em que pese sua pretensa universalidade. Malgrado a identificação de direitos do homem e do cidadão no contexto das revoluções, pode-se afirmar que o constitucionalismo 
acabou consagrando os direitos do cidadão, na medida em que apenas os nacionais tinham assegurados os seus direitos ${ }^{138}$.

O regime internacional de proteção dos direitos humanos, portanto, não conheceria avanços significativos até o final da Segunda Guerra Mundial, quando um clamor mundial se ergueu em nome de uma maior aproximação política, econômica e jurídica entre os povos. A criação, pois, da Organização das Nações Unidas (ONU) pode ser considerado como o marco verdadeiramente inicial do regime internacional de proteção dos direitos humanos ${ }^{139}$. Sob seus auspícios, a criação da Comissão de Direitos Humanos, em 1946, iniciou intenso trabalho no sentindo de elaborar um documento que respondesse aos anseios mundiais de uma resposta a altura das agruras vivenciadas ao longo das duas Grandes Guerras.

Ao cabo de pouco mais de dois anos, em 10 de dezembro de 1948, a $3^{\text {a }}$ Assembléia Geral da ONU aprovou a Resolução 217 A, a qual adotava e proclamava a Declaração Universal de Direitos Humanos (DUDH). Em função de sua aprovação apenas enquanto Resolução da Assembléia Geral da ONU, iniciou-se longa discussão doutrinária e jurisprudencial a respeito de sua efetividade. Posto que desprovida dos atributos típicos de um tratado, Guido Soares identifica sua força vinculante no direito costumeiro internacional $^{140}$. É forçoso reconhecer, no entanto, que a partir da assinatura de tratados internacionais que regulam com maior eficácia e extensão os direitos humanos, a divergência doutrinária tornou-se meramente acadêmica.

Ainda a respeito da DUDH, é interessante mencionar que o seu título encerra verdadeiro contraste ao documento revolucionário francês, marcadamente pela ausência da palavra "cidadão" em seu título. Pode-se dizer que tal fato representa enorme conquista na

\footnotetext{
${ }^{138}$ Interessante lembrar a situação vivenciada pelos apátridas na primeira metade do século XX. Uma vez que a defesa dos direitos humanos se resumia à positivação destes direitos no plano interno, o não-pertencimento a nenhum Estado causava graves prejuízos àqueles que não possuíam nenhuma nacionalidade. Hannah Arendt chega até mesmo a afirmar que os apátridas estavam expulsos da humanidade, Cf. ARENDT, Hannah. As Origens do Totalitarismo. Parte II - imperialismo (trad. Roberto Raposo). Rio de Janeiro: Documentário, 1976. p. 234. Em outra passagem dramática, a autora assevera que o criminoso possuía melhor situação jurídica que os apátridas, a partir da garantia de mínimos direitos constitucionais inerentes ao procedimento penal, $\mathrm{Cf}$. Idem. op.cit. p. 224-225.

${ }^{139}$ LAFER, Celso. A Reconstrução dos Direitos Humanos: um diálogo com o pensamento de Hannah Arendt. São Paulo: Companhia das Letras, 1988. p. 150.

140 SOARES, Guido F. S. Curso de Direito Internacional Público. São Paulo: Atlas, 2002. p. 345. O autor ainda colaciona decisão da Corte Internacional de Justiça que corrobora sua posição, em caso envolvendo os Estados Unidos e Irã, pelos episódios ocorridos em 1979. Também neste sentido, FELAMINGO, Fabrício. op. cit. p. 20, nota 11. Estudaremos novamente a questão da eficácia das normas internacionais decorrentes de tratados e declarações no item 2.3 deste presente estudo.
} 
promoção e defesa dos direitos humanos. Doravante, os direitos anunciados seriam inerentes à condição humana, despegada de particularismos nacionais ${ }^{141}$. Justamente em razão deste avanço, Norberto Bobbio identifica na DUDH o encerramento de um ciclo evolutivo marcado pelo início da positivação internacional dos direitos humanos:

\footnotetext{
“A Declaração Universal contém em germe a síntese de um movimento dialético, que começa pela universalidade abstrata dos direitos naturais,transfigura-se na particularidade concreta dos direitos positivos e termina na universalidade não mais abstrata, mas também concreta, dos direitos positivos universais"142.
}

Assim, a universalização da proteção dos Direitos Humanos, dentre eles o direito à educação básica, depende hodiernamente de uma atuação protetiva para além das fronteiras do Estado-nação e suas limitações juridico-políticas. Nos dizeres de Flávia Piovesan, a proteção dos direitos humanos "não se deve reduzir ao domínio reservado do Estado, isto é, não se deve restringir à competência nacional exclusiva ou à jurisdição doméstica exclusiva, porque revela tema de legítimo interesse internacional". ${ }^{143}$

Antonio Augusto Cançado Trindade, por sua vez, identifica ganhos na dupla proteção jurídica, salientando que ambos os ordenamentos caminham juntos no sentido promover o propósito precípuo da proteção do ser humano ${ }^{144}$. Na lição de Alberto do Amaral Júnior, tanto o ordenamento internacional quanto o nacional devem ser conjugados de forma a fornecer sempre a mais ampla proteção aos tutelados. Neste intento, defende o autor que prevalece, em caso de conflito, a norma mais favorável na interpretação destes tratados,

\footnotetext{
"Ao atenuar a perspectiva de conflito, o critério de aplicação da norma mais favorável coordena os tratados que se inspiram nos mesmos propósitos. Referida coordenação tem lugar, tanto no nível vertical, entre tratados e leis domésticas, quanto no nível horizontal, entre dois ou mais tratados. O objetivo primordial é, em todos os casos, verificar qual é a norma que dispensa maior proteção às vítimas de violações de direitos humanos"145.
}

Contudo, quais são as características destes direitos humanos? A fim de esposarmos uma definição teórica de direitos humanos, valemo-nos de Alberto do Amaral Júnior, o qual

\footnotetext{
${ }^{141}$ BOBBIO, Norberto. op. cit. p. 30. No mesmo sentido, FERRAJOLI, Luigi. op. cit. p. 57.

142 BOBBIO, Norberto. op. cit. p. 30.

${ }^{143}$ PIOVESAN, Flávia. "Concepção Contemporânea de Direitos Humanos". op. cit. p. 15.

144 TRINDADE, Antônio Augusto Cançado. A Incorporação das Normas Internacionais de Proteção dos Direitos Humanos no Direito Brasileiro. San Jose: IIDH, ACNUR, CIVC, CUE, 1996. p. 235

${ }^{145}$ AMARAL, JUNIOR, Alberto do. Introdução ao Direito Internacional Público. São Paulo: Atlas, 2008. p. 104.
} 
tomando por base os ensinamentos de Robert Alexy, afirma cinco características principais, reproduzidas aqui em sua totalidade por entendermos sintetizar, com grande maestria, a essência dos fundamentos dos direitos humanos:

\begin{abstract}
"1. São direitos universais. Os direitos humanos são universais em relação aos seus titulares e destinatários. Os seres humanos são os únicos sujeitos com capacidade para exercê-los.
\end{abstract}

2. São direitos morais. A validade dos direitos morais independe da positivação efetuada pela norma jurídica. A norma vale, no plano moral, se puder ser justificada racionalmente perante todos aqueles que a aceitam. Os direitos do homem são direitos morais sempre que puderem ser justificados em face dos indivíduos aos quais se destinam.

3. São direitos preferenciais. Os direitos morais exigem que a ordem jurídica lhes ofereça proteção. Há, nesse sentido, um direito moral que pleiteia a tutela e o reconhecimento dos direitos humanos. Eles gozam, no confronto com outros direitos, de uma posição de prioridade no quadro das normas jurídicas existentes.

4. São direitos fundamentais. Os direitos do homem compreendem interesses e carências essenciais aos seres humanos. Os interesses e carências são fundamentais quando a sua violação ou não-satisfação provocarem a morte ou grave sofrimento dos indivíduos ou quando afetarem o núcleo essencial da autonomia. Eles são protegidos tanto pelos direitos liberais clássicos quanto pelos direitos sociais, que asseguram condições mínimas de existência.

5. São direitos abstratos. Esta particularidade é indissociável do estabelecimento de limitações, sem as quais nenhuma aplicação concreta se mostrará viável. É preciso, por isso, conceber instâncias encarregadas de promover ponderações juridicamente obrigatórias. O Estado é, nessa conjuntura, uma instância decisiva para a concretização e efetivação dos direitos humanos". ${ }^{146}$

Diante destas características, Flávia Piovesan reforça ainda a historicidade e indivisibilidade dos Direitos Humanos. Enquanto históricos, seriam um constructo social cujo contínuo "processo de construção e reconstrução" é permeado pelos cambiantes anseios e necessidades do gênero humano ao longo do tempo. ${ }^{147}$ No que tange a indivisibilidade, diz a autora:

\footnotetext{
"Indivisibilidade porque a garantia dos direitos civis políticos é condição para a observância dos direitos sociais, econômicos e culturais, e vice-versa. Quando um deles é violado, os demais também o são. Os direitos humanos compõem assim uma unidade indivisível, interdependente e inter-relacionada, capaz de conjugar o catálogo de direitos civis e políticos ao catálogo de direitos sociais, econômicos e culturais." $" 148$
}

\footnotetext{
${ }^{146}$ Idem. op. cit. p. 439-440.

${ }^{147}$ PIOVESAN, Flávia. Direitos Humanos, Globalização Econômica e Integração Regional. In: PIOVESAN, Flávia (org.). Direitos Humanos, Globalização Econômica e Integração Regional - Desafios do Direito Constitucional Internacional. São Paulo: Max Limonad, 2002. p. 40. No mesmo sentido: BOBBIO, Norberto. op. cit. p. 18.

${ }^{148}$ PIOVESAN, Flávia. op. cit., p. 41. Em consonância com o Parágrafo 5. da mencionada Declaração: “Todos os direitos humanos são universais, interdependentes e inter-relacionados. A comunidade internacional deve
} 
Paralelamente ao desenvolvimento de um sistema global de proteção dos direitos humanos, assistimos ao paulatino crescimento dos sistemas regionais de proteção, dentre os quais se destacam o europeu - iniciado pela aprovação da Convenção Européia de Direitos Humanos ${ }^{149}$ e o americano. A experiência continental americana ganhou corpo por meio da adoção da Carta da Organização dos Estados Americanos ${ }^{150}$, ao final da IX Conferência Internacional dos Estados Americanos, sediada em Bogotá, em abril de 1948. Nesta mesma reunião, os Estados presentes apresentaram a Declaração Americana dos Direitos e Deveres do Homem (DADDH), aprovada pela Resolução XXX, ou seja, antes mesmo do DUDH.

Acerca da sobreposição jurídica oferecida pela conjugação das normas universais e continentais de direitos humanos, Flávia Piovesan advoga pela formação de um verdadeiro sistema internacional de proteção, como resultado direto do processo de universalização destes direitos. Neste sentido, a convivência harmônica de ambos os sistemas apenas reforça o grau de importância da eficácia da proteção dos direitos humanos. Conclui a autora que

\begin{abstract}
"Esse sistema é integrado por tratados internacionais de proteção que refletem, sobretudo, a consciência ética contemporânea compartilhada pelos Estados, na medida em que invocam o consenso internacional acerca de parâmetros protetivos mínimos relativos aos direitos humanos (o "mínimo ético irredutível”) (...) Ao lado do sistema normativo global, surgem os sistemas regionais de proteção, que buscam internalizar os direitos humanos nos planos regionais, particularmente na Europa, América e África. (...) Os sistemas global e regional não são dicotômicos, mas complementares. Inspirados pelos valores e princípios da Declaração Universal, compõem o universo instrumental de proteção dos direitos humanos, no plano internacional" 151
\end{abstract}

É justamente este universo instrumental de proteção dos direitos humanos que será objeto de nossa análise, guiados pela defesa do direito à educação básica.

tratar os direitos humanos globalmente de forma justa e equitativa, em pé de igualdade e com a mesma ênfase". Para um estudo mais detido a respeito de cada um destes aspectos dos direitos humanos, ver LIMA JUNIOR, Jayme Benvenuto. Os Direitos Humanos Econômicos, Sociais e Culturais. Rio de Janeiro: Renovar, 2001. p. 65-84. Note-se que estas características também encontraram guarida no parágrafo quinto da Declaração de Direitos Humanos de Viena, de 1993, que prevê que "todos os direitos humanos são universais, interdependentes e inter-relacionados. A comunidade internacional deve tratar os direitos humanos globalmente de forma justa e equitativa, em pé de igualdade e com a mesma ênfase".

${ }^{149}$ A Convenção Européia data de 1950. Contudo, uma nova Carta de Direitos Fundamentais foi aprovada no seio da União Européia, em 07.12.2000. Em especial sobre a educação, o artigo 14 do documento estabelece que "todas as pessoas tem direito à educação, bem como ao acesso à formação profissional e contínua", acrescendo que "esse direito inclui a possibilidade de freqüentar gratuitamente o ensino obrigatório".

${ }^{150}$ Este documento foi reformado posteriormente pelo Protocolo de Buenos Aires, em 1967, e pelo Protocolo de Cartagena das Índias, em 1985.

${ }^{151}$ PIOVESAN, Flávia. "Concepção Contemporânea de Direitos Humanos". op. cit. p. 17. 


\title{
$\underline{\text { 2.1.1 - A Educação nas Primeiras Declarações de Direitos Humanos }}$
}

A educação, entendida como parte integrante do rol dos direitos humanos, esteve presente nas primeiras declarações de direitos firmados no plano global e continental. Desta feita, tanto a DUDH quanto a DADDH dedicaram-se a proclamar a relevância do direito à educação, estabelecendo importantes diretrizes para o ensino, sobretudo em seus primeiros níveis. Esta deferência à educação básica será a tônica dos tratados e declarações internacionais que se seguirão, os quais estudaremos em item posterior.

\section{O artigo XXVI da DUDH afirma:}

\begin{abstract}
“Artigo XXVI - 1. Todo ser humano tem direito à instrução. A instrução será gratuita, pelo menos nos graus elementares e fundamentais. A instrução elementar será obrigatória. A instrução técnico-profissional será acessível a todos, bem como a instrução superior, esta baseada no mérito.
\end{abstract}

2. A instrução será orientada no sentido do pleno desenvolvimento da personalidade humana e do fortalecimento do respeito pelos direitos humanos e pelas liberdades fundamentais. A instrução promoverá a compreensão, a tolerância e a amizade entre todas as nações e grupos raciais ou religiosos, e coadjuvará as atividades das Nações Unidas em prol da manutenção da paz.

3. Os pais têm prioridade de direito na escolha do gênero de instrução que será ministrada a seus filhos". ${ }^{152}$

Em que pese sua pretensão de universalidade, a Declaração é extremamente clara e precisa ao tratar da educação, não se valendo de subterfúgios legais ou lingüísticos para enunciar a gratuidade e obrigatoriedade do ensino em seu nível elementar (Cine 01). A gratuidade também é estendida ao grau fundamental, de modo que a declaração visava a atender os educandos em idade escolar de até quatorze anos (Cine 02 e 03). Afirma-se, igualmente, a liberdade parental na definição da instrução de seus filhos.

Reza o artigo 12 da DADDH:

“Artigo 12 - Toda pessoa tem direito à educação, que deve inspirar-se nos princípios de liberdade, moralidade e solidariedade humana. Tem, outrossim, direito

\footnotetext{
152 Grifos nossos. Versão em português obtida na página eletrônica da missão da ONU no Brasil, disponível em: http://www.onu-brasil.org.br/documentos_direitoshumanos.php. Acesso em 23 de janeiro de 2010.
} 
a que, por meio dessa educação, lhe seja proporcionado o preparo para subsistir de uma maneira digna, para melhorar o seu nível de vida e para poder ser útil à sociedade. $\mathrm{O}$ direito à educação compreende o de igualdade de oportunidade em todos os casos, de acordo com os dons naturais, os méritos e o desejo de aproveitar os recursos que possam proporcionar a coletividade e o Estado. Toda pessoa tem o direito de que lhe seja ministrada gratuitamente pelo menos, a instrução primária" 153 .

Percebe-se, portanto, que diferentemente de sua contraparte universal, a Carta continental não estabelece expressamente a obrigatoriedade do ensino primário (Cine 01), porém assegura a sua gratuidade. Introduz, no entanto, o mote da igualdade enquanto princípio norteador do oferecimento da educação. Ademais, não há nenhuma menção à liberdade parental na escolha da instrução, como ocorre na DUDH. É curioso mencionar que a DADDH é o único documento internacional que prevê o dever do titular do direito à educação em concluir, no mínimo, o nível primário de ensino (Cine 01), conforme disposto no artigo 31 do referido documento.

Cotejando-se os dois documentos colacionados, deduz-se que a ousadia da carta universal sobrepuja a proteção dedicada ao direito à educação pela carta continental. É inegável que a dificuldade em se costurar consensos no plano universal é maior que no plano continental, por mais acentuadas que sejam as diferenças culturais, lingüísticas, econômicas e políticas. Assim, acreditamos ter havido excesso de timidez por parte dos signatários continentais, os quais firmariam parâmetros maiores de proteção no plano universal, em menos de um ano.

Por fim, cumpre lembrar que tanto o plano universal quanto o plano continental conhecerão tratados internacionais que buscarão conferir maiores detalhes jurídicos ao conteúdo do direito à educação, bem como assegurar efetivamente a sua realização, por meio da responsabilização do Estado na sua prestação. Estes documentos serão estudados no item 2.4. No próximo item, trataremos da conceituação de tratado internacional, diferenciando-o das declarações de direito.

\footnotetext{
153 Grifos nossos. Tradução para o português encontrada na página eletrônica da biblioteca virtual da Universidade de São Paulo, disponível em http://www.direitoshumanos.usp.br/index.php/OEAOrganiza\%C3\%A7\%C3\%A3o-dos-Estados-Americanos/declaracao-americana-dos-direitos-e-deveres-dohomem.html. Último acesso em 23 de janeiro de 2010.
} 


\section{2 - Tratados Internacionais}

A doutrina discorre longamente a respeito dos tratados internacionais e as principais características de seu nascimento, vida e morte. No presente estudo, contudo, buscamos apenas fornecer, em apertada síntese, as principais características constitutivas dos tratados internacionais, além de sua extinção. Tal estudo se mostra fundamental para compreendermos a diferenciação entre as declarações e tratados internacionais, bem como a estrutura das normas jurídicas internacionais que regulam o direito à educação básica.

\section{$\underline{2.2 .1 \text { - Conceito de Tratado Internacional }}$}

Os tratados internacionais inserem-se entre as fontes formais de Direito Internacional Público (DIP). Estas se encontram relacionadas no rol do artigo 38 do Estatuto da Corte Internacional de Justiça (CIJ), observando ainda a existência do costume internacional, dos princípios gerais de direito, a jurisprudência e a doutrina. ${ }^{154}$ Ensina-nos Alberto do Amaral Júnior que não há qualquer estipulação hierárquica expressa a respeito dos costumes, convenções e os princípios gerais de direito, gozando estes de "idêntica relevância jurídica". 155

Todavia, percebe-se que, ao longo dos últimos dois séculos, paulatinamente as convenções suplantaram a posição tradicional dos costumes como principal fonte deste ramo jurídico, em virtude do desenvolvimento dos tratados internacionais multilaterais e da

\footnotetext{
${ }^{154}$ Art. 38 do Estatuto da CIJ: "1. A Corte, cuja função é decidir de acordo com o direito internacional as controvérsias que lhe forem submetidas, aplicará: a) as convenções internacionais, quer gerais, quer especiais, que estabeleçam regras expressamente reconhecidas pelos Estados litigantes; b) o costume internacional, como prova de uma prática geral aceita como sendo o direito; os princípios gerais de direito, reconhecidos pelas nações civilizadas; e, d) sob ressalva da disposição do art. 59, as decisões judiciárias e a doutrina dos juristas mais qualificados das diferentes nações, como meio auxiliar para a determinação das regras de direito." Apesar de não estarem mencionadas no referido artigo, grande parte da doutrina apresenta como fonte de DIP os atos unilaterais dos Estados e os atos típicos das organizações internacionais. Neste sentido, AMARAL JÚNIOR, Alberto do. Introdução ao Direito Internacional Público. São Paulo: Atlas, 2008. p. 126-129 e p. 170-178.

${ }^{155}$ Idem. op. cit. p. 45.
} 
proliferação de organizações internacionais. ${ }^{156}$ Por outro lado, é inegável que assistimos hoje à revalorização do direito costumeiro, em virtude do desenvolvimento de grandes mercados internacionais regidos por normas costumeiras, bem como a ostensiva utilização dos costumes em questões jurídicas de Direito Humanitário. ${ }^{157}$

Hodiernamente, o instituto dos tratados internacionais é disciplinado pela Convenção de Viena sobre o Direito dos Tratados (CVDT), fruto dos esforços envidados pela Comissão de Direito Internacional da ONU e responsável pela codificação do direito internacional consuetudinário referente ao tema. ${ }^{158}$ Pela definição jurídica, apresentada no art.2 ${ }^{\circ}$, "a", do mencionado diploma legal, tratado internacional é

\footnotetext{
"acordo internacional celebrado por escrito entre Estados e regido pelo Direito Internacional, quer conste de um documento único, quer de dois ou mais instrumentos conexos, qualquer que seja sua denominação particular”.
}

Em virtude da definição adotada, evidencia-se uma lacuna significativa, sanada somente a partir da assinatura da Convenção sobre o Direito dos Tratados entre Estados e Organizações Internacionais ou entre Organizações Internacionais, datada de 1986, em que se determinou o reconhecimento explícito da possibilidade de celebração de tratados pelas organizações internacionais, entendidas, portanto, como sujeito de direitos e deveres de Direito Internacional Público. ${ }^{159}$

Outro desdobramento relevante da definição de tratado internacional corresponde à adoção de nomenclaturas entre os diplomas jurídicos que estruturam e expressam as convenções internacionais. A norma expressamente não reconhece qualquer distinção ou estabelece significação jurídica diversa para as diferentes denominações que comumente

\footnotetext{
${ }^{156}$ Idem. op. cit. p. 46. Ressalta, ainda, o autor que os tratados multilaterais - convenções que envolvem a participação de mais de dois Estados - desenvolveram-se a partir do Congresso de Viena, em 1815, encerrando a percepção do tratado enquanto instrumento de acordo formal entre apenas dois Estados.

${ }^{157}$ DALLARI, Pedro B. A. op. cit., p. 14. Também, AMARAL JÚNIOR, Alberto do. op. cit. p. 117-120.

158 A Convenção de Viena sobre o Direito dos Tratados foi firmada em 22.05.1969, porém, entrou em vigor apenas em 27.01.1980, após trinta dias decorridos da data do depósito do trigésimo quinto instrumento de ratificação nacional, conforme previsto no art.84, 1, do mencionado diploma. Salienta-se que o Brasil ainda não ratificou a mencionada convenção, carecendo, até o presente momento, de autorização legislativa para tanto. A tradução para o português empregada neste trabalho foi encontrada em DALLARI, Pedro B. A. op. cit. p. 177214. Esclarece o autor que esta versão reproduz fidedignamente o texto da Mensagem Presidencial n. 166/92, encaminhada ao Congresso Nacional, com vistas a instruir a apreciação parlamentar do referido tratado internacional.

${ }^{159}$ De acordo com o art. $6^{\circ}$ da referida Convenção, "a capacidade de uma organização internacional para concluir tratados é regida pelas regras da organização".
} 
intitulam as convenções internacionais, a saber, convenção, carta, estatuto, protocolo, acordo, convênio, pacto, memorando etc ${ }^{160}$.

Destarte, Pedro Dallari preceitua tratado internacional como "diploma jurídico que estrutura e expressa uma norma de conduta convencionada internacionalmente, a partir da vontade manifesta de Estados ou organizações internacionais". ${ }^{161}$ No mesmo sentido, Francisco Rezek arremata que "tratado é todo acordo formal concluído entre sujeitos de Direito Internacional Público, e destinado a produzir efeitos jurídicos”. ${ }^{162}$

Das definições colacionadas depreende-se a importância de não olvidar que a essência do tratado internacional repousa na produção de efeitos jurídicos para as partes, tomando-se por base a adoção convencionada de uma conduta preferível. Por conseguinte, alguns instrumentos jurídicos não podem ser considerados tratados internacionais propriamente ditos, uma vez que não criam, modificam ou extinguem direitos entre as partes. Aponta Alberto do Amaral Júnior que

\begin{abstract}
"Tornou-se comum a elaboração de comunicados conjuntos ou declarações entre destacadas autoridades governamentais, normalmente chefes de Estado ou de governo, que exprimem pontos de vista por eles compartilhados sobre fatos ou acontecimentos. Tais atos não acarretam obrigações internacionais, mas simplesmente a expectativa de que os participantes agirão em conformidade com as posições expressas. Ilustram essa hipótese a Declaração do Rio sobre o Meio Ambiente e Desenvolvimento de 1992, a Declaração de Viena sobre os Direitos Humanos de 1993 e a Declaração de Doha celebrada pelos membros da Organização Mundial de Comércio em novembro de 2001". ${ }^{163}$
\end{abstract}

A obrigatoriedade dos tratados decorre, portanto, do consentimento expresso das partes em obrigar-se. Contudo, não raras são as ocasiões em que os Estados, após a celebração de determinado tratado, atuem de forma a ofender o previamente pactuado. De forma a mitigar o voluntarismo político e jurídico dos Estados com relação ao Direito

\footnotetext{
${ }^{160}$ A respeito das diferentes nomenclaturas para os tratados internacionais, Pedro Dallari, em oportuna síntese, afirma: "A doutrina, com respaldo inclusive nas mencionadas Convenções de Viena, é hoje praticamente consensual na constatação de que: a) independentemente da denominação, o documento que estiver revestido das características genéricas apontadas nas conceituações convencionais e doutrinárias anteriormente indicadas deve ser considerado tratado internacional; b) as diferentes denominações que poderem receber os tratados não se prestam a estabelecer qualquer diferenciação de fundo jurídico entre si; c) tais denominações, dada a ausência de padrões na sua utilização, dificilmente contribuem para o sucesso de qualquer esforço voltado à produção de classificação tipologia dos tratados quanto aos respectivos propósitos e conteúdos”, Cf. DALLARI, Pedro B. A. op. cit. p. $17-18$.

${ }^{161}$ Idem. op. cit., p. 17.

${ }^{162}$ REZEK, Francisco. Direito Internacional Público (curso elementar). $7^{\mathrm{a}}$ ed. rev. Saraiva: São Paulo, 1998. p. 14.

${ }^{163}$ AMARAL JÚNIOR, Alberto do. op. cit. 48.
} 
Internacional, institui-se o conceito do pacta sunt servanda, i.e. "o pacto submete", consagrado formalmente no artigo 26 da CVDT.

Por este princípio, busca-se construir uma ordem jurídica internacional que conceda eficácia à vontade soberana dos Estados no sentido de sua autolimitação no plano internacional, por meio de instrumentos jurídicos próprios, como os tratados internacionais. ${ }^{164}$ Ressalte-se que o artigo 27 da CVDT veda expressamente a possibilidade de invocação do direito interno enquanto justificativa para o inadimplemento de um tratado internacional, reforçando assim a responsabilização internacional a partir do seu consentimento expresso no plano supraestatal.

Em contraponto ao "pacta sunt-servantismo", 165 teóricos da vertente realista das Relações Internacionais ${ }^{166}$, como britânico Edmund H. Carr, passaram a defender a prerrogativa nacional da violabilidade dos tratados internacionais assumidos por um determinado país. Segundo este autor, estaria assentado que todo e qualquer tratado internacional possuiria em seu bojo, ainda que implicitamente, a reserva rebus sic standibus, i.e. "as coisas como estão", que determinaria a eficácia do tratado apenas enquanto "as condições que prevaleciam à época da conclusão do tratado continuassem". ${ }^{167}$ Saliente-se que a própria CVDT veio a reconhecer a existência desta cláusula, conforme veremos a seguir.

${ }^{164}$ HELLER, Hermann. Teoria do Estado (trad. Lycurgo Gomes da Motta), São Paulo: Mestre Jou, 1968. p. 233. Também a esse respeito: KELSEN, Hans. Teoria Geral do Direito e do Estado (trad. Luis Carlos Borges). Martins Fontes, São Paulo, 1992.

${ }_{165}$ Expressão colhida na obra de CARR, Edmund H. Vinte Anos de Crise 1919-1939 (trad. Luiz Alberto Figueiredo Machado). $2^{\mathrm{a}}$ ed. Brasília: Universidade de Brasília, 2000, p. 235.

${ }^{160}$ A visão realista clássica das Relações Internacionais se caracteriza notadamente pela identificação de uma sociedade internacional anárquica, formada apenas por Estados soberanos juridicamente independentes, que se relacionam por relações horizontais, em razão do princípio da igualdade formal entre estes. Os Estados, por sua vez, movem-se de acordo com seus interesses nacionais - portanto de forma racional - os quais possuem primazia absoluta na conduta da política externa estatal, seja em relação à política interna ou mesmo ao Direito Internacional. Cf. BATTISTELLA, Dario. Théorie des Relations Internacionales. Paris: Presses de Sciences Po, 2004. p. 111-138.

${ }^{167}$ CARR, Edmund H. op. cit., p. 236. O autor ainda apresenta famosa citação do chanceler alemão Otto von Bismarck, grande arquiteto da unificação alemão, em que afirma que "todo tratado tem apenas o significado de uma constatação de uma posição definida nos assuntos europeus. A reserva rebus sic standibus está sempre subentendida". Para fundamentar a aplicação jurídica de tal reserva, Carr propõe que seja observada a ausência de simetria horizontal real de força entre os Estados que compõem o plano internacional, assim como de um poder supranacional com jurisdição internacional, o que acaba por eivar as vontades constituintes dos tratados de vício de consentimento, como a coação, por exemplo. Assim, atesta o autor que "somente quando estas forças estão em equilíbrio pode o direito cumprir sua função social, sem se tornar uma ferramenta nas mãos dos defensores do status quo. Atingir esse equilíbrio não é uma tarefa legal, e sim política" Ademais, a utilização do Direito Internacional enquanto instrumento de poder no plano político externo retiraria deste qualquer legitimidade para a exigência do cumprimento dos tratados, pois, "não se negou que as violações de tais tratados eram tecnicamente violações do direito internacional; mas foram toleradas em termos de que os próprios tratados eram uma ofensa contra a moral internacional", Cf. Idem. op. cit. p. 242. 


\subsection{2 - Nascimento, Vida e Morte dos Tratados Internacionais}

A manifestação do consentimento das partes, por sua vez, está intimamente ligada ao surgimento e início da vigência e obrigatoriedade dos tratados internacionais. De acordo com o artigo 11 da CVDT, esse consentimento pode ocorrer pela assinatura, troca dos instrumentos constitutivos do tratado, ratificação, aceitação ou adesão, além de qualquer outro meio convencionado pelo documento.

Fabrício Felamingo aponta a existência de duas fases distintas de elaboração de um tratado internacional. A primeira fase ocorre no âmbito internacional, por meio das tratativas e negociações entre as partes a respeito do tratado, de modo que a assinatura do documento teria o condão de encerrá-la ${ }^{168}$. Alguns tratados internacionais, conforme preleciona Alberto do Amaral Júnior, possuem o condão de gerar direitos e obrigações às partes já ao final desta etapa, independente de aprovação parlamentar, citando como exemplo os tratados celebrados na sua forma simplificada ou ainda os executive agreements ${ }^{169}$.

Quando da assinatura do tratado internacional, podem as partes decidir pela apresentação de reserva, que consiste em "decisão unilateral de vontade que exclui ou modifica o efeito jurídico de algumas disposições do tratado em face daquele que a formulou" ${ }^{170}$. Tal artifício, quando permitido pelo texto do tratado internacional, é utilizado na busca por arregimentar o maior número de signatários possível, permitindo a participação àqueles que possuam objeções apenas pontuais ao conteúdo jurídico avençado.

\footnotetext{
168 Diz o autor: "A primeira fase é a internacional, entendida como a fase de conversas e tratativas entre os Estados, representados por agentes habilitados para tanto, com vistas a um acordo futuro. Esta negociação assume diferentes formas: comunicação entre as partes, encontros bilaterais ou multilaterais de representantes, conferências internacionais etc. A assinatura encerra a etapa internacional de elaboração do tratado, exceto pela posterior e eventual necessidade do depósito e registro de um instrumento de ratificação, através do qual o Estado não apenas confirmará seu assentimento com o tratado, como também passa a formalmente obrigar-se em relação ao seu cumprimento, sendo passível de responsabilização internacional", Cf. FELAMINGO, Fabrício. FELAMINGO, Fabrício. A Hierarquia dos Tratados Internacionais de Direitos Humanos - uma análise a partir da Emenda Constitucional 45/2004. Dissertação de Mestrado, Direito das Relações Econômicas Internacionais, PUC, 2008. p. 20.

${ }^{169}$ AMARAL JÚNIOR, Alberto do. op. cit. 51. Ensina-nos o autor que os executive agreements nasceram da experiência parlamentar estadunidense, diante da imensa dificuldade de aprovação dos tratados internacionais mediante o procedimento constitucional. Contudo, usualmente este tipo de tratado é concluído mediante delegação expressa de poderes ao Presidente do país, a qual também apresenta expressos limites legais para a sua utilização.

${ }^{170}$ Idem. op. cit. p. 58.
} 
Sinaliza Alberto do Amaral Júnior que a utilização de reservas nos tratados de direitos humanos, foco do nosso estudo em razão do direito à educação básica, é indefensável, uma vez que as reservas comprometem o grau de comprometimento das partes no que tange aos direitos e garantias previstos no documento. Advoga o autor que

\footnotetext{
"É sabido que tais tratados, por instituírem garantias coletivas e protegerem a dignidade do homem, reclamam consideração especial afeita aos traços próprios que os singularizam. Não é aceitável por esse motivo que o alcance das obrigações convencionais dependa da vontade das partes, em flagrante antagonismo com as razões superiores que inspiraram a estipulação desses compromissos. (...) A doutrina tenda a condenar as reservas que venham a cercear a competência dos órgãos de supervisão criados pelos tratados de direitos humanos ou que possibilitem a violação de direitos inderrogáveis.",171
}

A segunda fase engloba tanto o procedimento nacional de reapreciação do tratado, quanto o eventual posterior envio ou depósito do instrumento de ratificação ou aceitação do documento internacional ${ }^{172}$. O reexame dos tratados internacionais pelos parlamentos denota a importância da articulação dos Poderes Políticos em torno das obrigações internacionais, mitigando-se uma concentração excessiva de poderes nas mãos do Poder Executivo, usual responsável pela celebração dos acordos internacionais.

Os procedimentos de ratificação dos tratados internacionais, frise-se, não são disciplinados pelo Direito Internacional, quedando-se sob a guarda da ordem jurídica interna. Tampouco trata a normativa internacional a respeito da hierarquia jurídica do tratado internacional perante o ordenamento nacional, a qual também será definida pela legislação interna. Estudaremos especificamente no item seguinte a integração dos tratados internacionais ao plano normativo nacional, de modo que nos abstemos, por ora, de apresentar considerações a esse respeito neste momento.

Cumpre mencionar que os Congressos Nacionais deverão analisar não apenas o texto integral do tratado internacional, bem como as reservas que porventura tenham sido apresentadas. Outrossim, poderão apresentar novas limitações ao documento, caso julguem apropriado. Ao final do trâmite interno para a apreciação dos tratados internacionais, deverá a parte proceder à ratificação, isto é, realizar a entrega da comunicação formal do resultado às

\footnotetext{
${ }^{171}$ Idem. op. cit. p. 59.

${ }^{172}$ Nas palavras de Fabrício Felamingo: “A segunda etapa de elaboração do tratado internacional consiste justamente no procedimento interno de cada Estado até a expressão desse consentimento internacional, isto é, até o envio ou depósito do instrumento de ratificação ou aceitação, momento em que o Estado passa a consentir em obrigar-se internacionalmente pelo tratado", Cf. FELAMINGO, Fabrício. op. cit. p. 23.
} 
outras partes ou ao depositário do tratado, o que ocorre mediante o depósito do instrumento de ratificação.

A conclusão do rito de ratificação do tratado internacional não enceta automaticamente a produção de efeitos jurídicos para as partes, salvo quando há disposição neste sentido. Consoante o disposto no artigo 24 da CVDT, prevalece o acordo entre as partes a respeito da forma e da data estipuladas para a entrada em vigor do documento internacional, sendo que o silêncio do texto acarreta a necessidade de manifestação do consentimento em obrigar-se por parte de todos os negociadores ${ }^{173}$.

Os tratados multilaterais usualmente dispõem que a entrada em vigor das obrigações jurídicas ocorrerá em função de um número mínimo de depósitos de instrumentos de ratificação, ou ainda, de uma data estabelecida ${ }^{174}$. Enquanto não se atinge o critério estabelecido pelo tratado, os efeitos jurídicos costumeiramente ficam sobrestados para as partes que já procederam ao depósito do instrumento de ratificação, salvo se o tratado dispuser contrariamente, de acordo com o artigo 25 do CVDT.

A esse respeito, Fabrício Felamingo distingue entre vigência objetiva e vigência subjetiva do tratado internacional. Enquanto a vigência objetiva corresponde à produção de efeitos jurídicos para todas as partes negociadoras, uma vez preenchidos todos os requisitos previstos para tanto, a vigência subjetiva diz respeito à produção de efeitos jurídicos para a parte específica, podendo ter início antes mesmo da vigência objetiva, por força do artigo 25 do CVDT, que trata da aplicação provisória dos tratados internacionais ${ }^{175}$.

Alguns tratados internacionais permitem o ingresso mediante adesão, cuja natureza jurídica pouco difere da ratificação. Explica Francisco Rezek que, caso o interessado não

\footnotetext{
${ }^{173}$ Convenção de Viena sobre o Direito dos Tratados, artigo 24: "1. Um tratado entra em vigor na forma e na data previstas no tratado ou acordadas pelos Estados negociadores; 2. Na ausência de tal disposição ou acordo, um tratado entra em vigor tão logo o consentimento em obrigar-se pelo tratado seja manifestado por todos os Estados negociadores; 3. Quando o consentimento de um Estado em obrigar-se por um tratado for manifestado após sua entrada em vigor, o tratado entrará em vigor em relação a esse Estado nessa data, a não ser que o tratado disponha de outra forma; 4. Aplicam-se desde o momento da adoção do texto de um tratado as disposições relativas à autenticação de seu texto, à manifestação do consentimento dos Estados em obrigarem-se pelo tratado, à maneira ou à data de sua entrada em vigor, às reservas, às funções de depositário e aos outros assuntos que surjam necessariamente antes da entrada em vigor do tratado".

174 À guisa de exemplo, conforme já mencionamos, a Convenção de Viena sobre o Direitos dos Tratados, datada de 1969, entrou em vigor no trigésimo dia após o depósito do trigésimo quinto instrumento de ratificação ou adesão, conforme o disposto em seu artigo 84 .

${ }^{175}$ FELAMINGO, Fabrício. op. cit. p. 25.
} 
tenha tomado parte nas negociações e assinatura do tratado internacional, não poderá ratificálo, valendo-se, portanto, do instituto da adesão ${ }^{176}$.

Por fim, discorreremos sucintamente sobre o procedimento de extinção dos tratados internacionais. As modalidades de extinção permitidas pela CVDT são: (a) vontade das partes (art. 54); (b) vontade unilateral (art. 56); e, (c) alteração das circunstâncias que fomentaram a disposição das partes para celebrar o acordo (art. 62).

Costumeiramente, os diplomas internacionais trazem disposições a respeito de sua extinção, existindo inúmeras modalidades para a sua instrumentalização ${ }^{177}$, o que denota uma ampla liberdade de pactuação para as partes envolvidas. Mesmo diante do silêncio do tratado a respeito de sua dissolução, as partes poderão convencionar o fim do ajuste a qualquer instante ${ }^{178}$.

A respeito das hipóteses de extinção do tratado internacional por vontade unilateral, esta se opera mediante o mecanismo da denúncia, a qual possui o condão de extinguir apenas os tratados bilaterais. No caso dos tratados multilaterais, o instituto promove o desligamento do denunciante, cessando os efeitos jurídicos apenas para a parte que pleiteia o afastamento do vínculo jurídico internacional. O direito de denúncia, salienta-se, prescinde de qualquer previsão anterior, condicionado o seu exercício ao respeito de algumas condições impostas pelo artigo 56 da $\mathrm{CVDT}^{179}$.

Outra forma de extinção permitida decorre da prevalência da cláusula rebus sic standibus, presente no direito internacional costumeiro e acolhida pelo artigo 62 da CVDT. Trata-se, em verdade, de derrogação expressa do princípio do pacta sunt servanda, de modo que deve ser aplicado apenas em situações excepcionais. Caso haja uma alteração fundamental e imprevista das circunstâncias que condicionaram a celebração do tratado, é lícito à parte que se sentir prejudicada pelo novo alcance das obrigações e efeitos contratuais

\footnotetext{
${ }^{176}$ REZEK, Francisco. op. cit. p. 90. Perceba-se que por esta caracterísitica, a adesão somente é possível nos casos de tratados multilaterais.

${ }^{177}$ A esse respeito, ver AMARAL JÚNIOR, Alberto do. op. cit. p. 107-108.

${ }^{178}$ Em atenção ao disposto no art. 54, b, da CVDT.

${ }^{179} \mathrm{O}$ referido artigo prevê que a parte denunciante, caso o tratado não contenha disposição relativa à sua extinção, deva notificar por escrito a sua intenção de denúncia a todas as partes ou ao depositário do documento, com pelo menos doze meses de antecedência.
} 
requerer a suspensão do tratado internacional em relação às suas obrigações ainda não cumpridas $^{180}$.

\section{3 - Integração dos Tratados Internacionais ao Direito Interno dos Estados-Membros do MERCOSUL}

Uma vez estudadas as linhas gerais de formação e extinção dos tratados internacionais, passaremos a analisar agora a integração dos tratados internacionais ao ordenamento jurídico interno dos Estados-Partes do MERCOSUL ${ }^{181}$. Neste intuito, também será concedida especial atenção aos tratados internacionais de direitos humanos, dentre os quais se inserem aqueles que versam sobre a educação básica.

A temática da integração dos tratados internacionais, contudo, esconde importante discussão a respeito do prestígio a eles dispensado pelo ordenamento nacional. A doutrina sói identificar duas grandes vertentes clássicas de análise para as relações entre o Direito Internacional e o Direito Interno: a corrente dualista e a corrente monista ${ }^{182}$.

\footnotetext{
${ }^{180}$ A redação do artigo 62 da CVDT enumera explicitamente as hipóteses de mudança fundamental de circunstâncias: "1. Uma mudança fundamental de circunstâncias, ocorrida em relação às existentes no momento da conclusão de um tratado, e não prevista pelas partes, não pode ser invocada como causa para extinguir um tratado ou dele retirar-se, salvo se: (a) a existência dessas circunstâncias tiver constituído uma condição essencial do consentimento das partes em obrigarem-se pelo tratado; e (b) essa mudança tiver por efeito a modificação radical do alcance das obrigações ainda pendentes de cumprimento em virtude do tratado. 2. Uma mudança fundamental de circunstâncias não pode ser invocada pela parte como causa para extinguir um tratado ou dele retirar-se: (a) se o tratado estabelecer limites; ou, (b) se a mudança fundamental resultar de violação, pela parte que a invoca, seja de uma obrigação decorrente do tratado, seja de qualquer outra obrigação internacional em relação a qualquer outra parte no tratado. 3. Se, nos termos dos parágrafos anteriores, uma parte pode invocar uma mudança fundamental de circunstâncias como causa para extinguir um tratado ou dele retirar-se, pode também invocá-la como causa para suspender a execução do tratado".

${ }^{181}$ Conforme aduz Cynthia Feldmann, "[a]l subscribir tratados internacionales, los Estados se comprometen a que las disposiciones en ellos contenidas se conviertan en derecho interno. Sin embargo, un Estado no puede invocar las disposiciones de su derecho interno como justificación del incumplimiento de un tratado", Cf. FELDMANN, Cynthia González. "La implementación de los tratados internacionales de derechos humanos por el Paraguay”. In: FELDMANN, Cynthia González (org.). El Paraguay frente al Sistema Internacional de los Derechos Humanos. Konrad Adenauer: Montevidéu, 2004. p. 20.

${ }^{182}$ Para um longo e aprofundado estudo a respeito das teorias clássicas do dualismo e monismo, consultar GARCIA JUNIOR, Armando Álvares. Conflito entre Normas do MERCOSUL e Direito Interno - como resolver o problema? O caso brasileiro. São Paulo: LTr, 1997. p. 127-157. Outro estudo interessante também pode ser encontrado em PAGLIARINI, Alexandre. Constituição e Direito Internacional: cedências possíveis. Rio de Janeiro: Forense, 2004. p. 34 e ss.
} 
Costumeiramente, identifica-se a gênese da doutrina dualista a partir dos estudos de Carl Heinrich Triepel ${ }^{183}$. Nas palavras de Armando Álvares Garcia Júnior:

\begin{abstract}
"a doutrina dualista, como o próprio nome está a indicar, sustenta a existência de duas ordens jurídicas igualmente válidas, embora distintas e absolutamente independentes: uma interna e uma internacional, de tal modo que a validade jurídica da primeira não se condiciona a sua sintonia com a ordem internacional. Para os adeptos desta teoria, o direito interno e o direito internacional caminhariam paralelamente (daí ser a teoria também denominada "paralelismo") sem nunca se tocarem (portanto, em princípio, jamais surgiriam conflitos entre suas regras. $\mathrm{O}$ conflito decorreria de um momento posterior, por ocasião da internalização da regra internacional por meio do mecanismo da 'incorporação'). Em outras palavras, os preceitos do direito internacional não revogam os que lhe são diversos do direito doméstico." ${ }^{184}$.
\end{abstract}

Dentro dessa perspectiva, formula-se a total separação entre instituições e fontes jurídicas dos dois ordenamentos, de modo que rigorosamente não se pode falar em integração dos dois sistemas, mas sim da recepção do Direito Internacional pelo Direito Interno. Aponta María Prujel que

\begin{abstract}
"En cuanto a la posición dualista, se debe tener en cuenta que ambos sistemas jurídicos (interno e internacional) se hallan separados, distinguidos por sus fuentes y por los sujetos que regulan; no es posible la penetración e integración. Será preciso, pues, un acto de novación de la norma que modifique totalmente su naturaleza. Esa novación opera como una transformación por la que se mediatiza la norma de derecho internacional con un acto de derecho interno (ley). (...) Dentro de esta concepción, no puede haber conflictos posibles entre los dos órdenes jurídicos, sino solamente reenvíos del uno al otro. Ahora, bien, como el derecho internacional no puede alcanzar a los individuos, requiere ser transformado en derecho interno" ${ }^{\text {"185. }}$.
\end{abstract}

Pode-se concluir, portanto, que para os partidários da posição dualista, a ordem jurídica internacional não possui validade no âmbito interno dos Estados, a qual somente logrará conseguir após o fiel cumprimento dos procedimentos legislativos de sua incorporação, ao final do qual será, na verdade, direito interno.

\footnotetext{
${ }^{183}$ Armando Álvares Garcia Júnior nos alerta que a nomenclatura foi dada por Alfred Verdross, em 1914, sendo posteriormente aceita por Triepel, em 1923, Cf. Idem. op. cit. p. 127.

${ }^{184}$ Idem. op. cit. p. 128.

${ }^{185}$ PRUJEL, María Elodia Almirón. "Los Derechos Humanos y la Constitución Nacional". In: FELDMANN, Cynthia González (org.). El Paraguay frente al Sistema Internacional de los Derechos Humanos. Konrad Adenauer: Montevidéu, 2004. p. 31.
} 
Para Pedro Dallari, trata-se de uma visão tributária de um momento específico das relações internacionais, onde predominavam normas de natureza contratual que visavam apenas a estabelecer as regras políticas de convivência entre os Estados soberanos. Ao longo do século XX, a questão ganha novos contornos pela intensificação da utilização dos tratados normativos de conteúdo normativo, os quais importam na "adoção de regras jurídicas uniformizadoras de padrões de conduta a serem observados pelos indivíduos e pessoas jurídicas de direito privado subordinados à soberania dos respectivos Estados contratantes no plano internacional" ${ }^{\prime 186}$.

Em contraponto à visão dualista, a teoria monista diferencia-se da proposta dualista quanto à relação entre as ordens jurídicas nacionais e internacionais, prevendo, de um modo geral, a existência de um único sistema jurídico, composto de dois planos normativos integrados ${ }^{187}$. Esta integração é a essência da concepção monista, que assume a perspectiva de unidade entre as ordens jurídicas. Esposando a doutrina monista, Celso de Albuquerque Mello afirma:

\footnotetext{
"A conclusão que se pode apresentar é que, sendo o Estado sujeito de Direito Interno e de Direito Internacional, é uma mesma pessoa. Não se podendo conceber que ele esteja submetido a duas ordens jurídicas que se chocam. É o Direito na sua essência um só. A ordem internacional acarreta a responsabilidade do Estado quando ele viola um de seus preceitos e o Estado aceita esta responsabilidade, como não poderia deixar de ser. Da constatação deste simples fato podemos observar que o Estado sujeito de direito das duas ordens jurídicas dá primazia ao Direito Internacional”. ${ }^{188}$
}

Há, no entanto, duas vertentes desta mesma concepção, de acordo com a primazia escolhida para determinado plano normativo: o monismo internacionalista e o monismo dito nacionalista. Neste sentido, é imprescindível que haja normas que apontem as relações hierárquicas entre os dois sistemas, de modo a solucionar eficazmente os eventuais casos de conflitos.

Talvez o maior expoente do monismo jurídico internacionalista, Hans Kelsen divorcia-se da posição dualista na medida em que identifica o Estado enquanto ordem jurídica fundamentada no Direito Internacional, pois "uma norma do Direito Internacional geral reconhece a um indivíduo ou a um grupo de indivíduos o poder de, com base numa

\footnotetext{
${ }^{186}$ DALLARI, Pedro. op. cit. p. 09.

${ }^{187}$ GARCIA JÚNIOR, Armando Alvares. op. cit. p. 141-142.

${ }^{188}$ MELLO, Celso D. de Albuquerque. Curso de Direito Internacional Público. $1^{\circ}$.vol. $11^{\text {a }}$.ed. Rio de Janeiro: Renovar, 1999. p.116
} 
Constituição eficaz, criar e aplicar, como governo legítimo, uma ordem normativa de coerção". ${ }^{189}$ Seguindo em seu raciocínio lógico, estabelece que "se o fundamento da vigência das ordens jurídicas estaduais se encontra numa norma da ordem jurídica internacional, esta é concebida como uma ordem jurídica superior àquelas e, portanto, como a ordem mais elevada de todas, como a ordem soberana". 190

Crítico desta vertente, Francisco Rezek defende que o primado do direito internacional sobre a ordem nacional se resume a uma proposição doutrinária, afirmando:

\begin{abstract}
"Resulta que para o Estado soberano, a constituição nacional, vértice do ordenamento jurídico, é a sede de determinação da estatura da norma expressa em tratado. Dificilmente uma dessas leis fundamentais desprezaria, neste momento histórico, o ideal de segurança e estabilidade da ordem jurídica a ponto de subpor-se, a si mesma, ao produto normativo dos compromissos exteriores do Estado. Assim, posto o primado da constituição em confronto com a norma pacta sunt servanda, é corrente que se preserve a autoridade da lei fundamental do Estado, ainda que isto signifique a prática de um ilícito pelo qual, no plano externo, deve aquele responder". ${ }^{191}$
\end{abstract}

Por fim, hodiernamente se aventa o chamado monismo de compatibilização, corrente que advoga a aproximação entre a doutrina dualista e monista, por meio de sua articulação. De acordo com Pedro Dallari, o monismo de compatibilização

\begin{abstract}
"deve implicar a integração das normas de Direito Internacional Público com o direito interno do Estado, mas, também, acarretar a substituição do enfoque baseado em torno da primazia de uma ou de outra ordem por uma perspectiva de articulação entre ambas, superando-se, assim, a polarização entre monismo internacionalista e monismo nacionalista" ${ }^{192}$.
\end{abstract}

Como é sabido, a hierarquia dos instrumentos internacionais em geral e, em particular, daqueles que versam sobre os direitos humanos, é determinada pelos próprios ordenamentos jurídicos nacionais, usualmente por meio da Constituição nacional, nosso estudo se pautará

\footnotetext{
${ }^{189}$ KELSEN, Hans. Teoria Pura do Direito (trad. João Baptista Machado). São Paulo: Martins Fontes, 2000. p. 240. Em seu intuito de centralizar a validade das normas jurídicas em uma única norma fundamental (grundnorm) como fundamento do sistema normativo, Kelsen afirma que "todas as normas cuja validade pode ser reconduzida a uma e mesma norma fundamental formam um sistema de normas, uma ordem normativa. A norma fundamental é a fonte comum da validade de todas as normas pertencentes a uma e mesma ordem normativa, o seu fundamento de validade comum", Cf. Idem. op. cit. p. 217.

${ }^{190}$ Idem. op. cit. p. 241.

${ }^{191}$ REZEK, Francisco. Direito Internacional Público: Curso Elementar. $7^{\mathrm{a}}$ ed. rev. São Paulo: Saraiva, 2007. p.102-103.

${ }_{192}$ DALLARI, Pedro B.A. op. cit. p. 13.
} 
pela análise constitucional do tema da integração ${ }^{193}$. Quando necessário, recorremos à apresentação de julgados dos tribunais superiores, a fim de encontrarmos pistas a respeito desta relação em face do silêncio constitucional.

\title{
2.3.1 - Argentina
}

A matéria da recepção constitucional dos tratados internacionais ganhou notória atenção na última reforma constitucional argentina, datada de 1994. Pode-se afirmar que se trata atualmente da Carta Magna MERCOSULina mais adiantada no que tange à relação do Direito Internacional ao Direito Interno. Contudo, tal posição foi alcançada após longa construção doutrinária e jurisprudencial, sobretudo em razão de seu artigo 31, apresentado a seguir na sua versão datada de 1860:

\begin{abstract}
Art. 31 ${ }^{\circ}$.- Esta Constitución, las leyes de la Nación que en su consecuencia se dicten por el Congreso y los tratados con las potencias extranjeras son la ley suprema de la Nación; y las autoridades de cada provincia están obligadas a conformarse a ella, no obstante cualquiera disposición en contrario que contengan las leyes o constituciones provinciales, salvo para la provincia de Buenos Aires, los tratados ratificados después del Pacto de 11 de noviembre de 1859.
\end{abstract}

Esta redação, segundo Luis Alberto Absi, proporcionou acalorado debate doutrinário e jurisprudencial. Se não havia dúvidas acerca da opção legislativa pelo monismo com supremacia constitucional, a incerteza pairava a respeito da relação entre os tratados internacionais e as leis federais ${ }^{194}$. O silêncio constitucional concedeu maior liberdade à atividade pretoriana, a qual passou a reconhecer, entre os tratados e leis federais, o princípio lex posteriori derrogat lex priori. Tal posição perdurou até o ano de $1992^{195}$.

Neste ano, conforme demonstra Carlos Constenla, houve uma mudança radical de posição da Suprema Corte argentina, a qual ganhou corpo a partir do julgado Ekmekdjan vs.

\footnotetext{
193 “O Direito Internacional não disciplina o procedimento de ratificação dos tratados, que é matéria a ser regulada pela ordem jurídica interna”, Cf. AMARAL JÚNIOR, Alberto do. op. cit. p. 51.

${ }^{194}$ ABSI, Luis Alberto. "Principios Generales de la Integración en El Derecho Positivo Argentino". In: Revista da Associação dos Juízes do Rio Grande do Sul - AJURIS. N. especial, 1998 novembro. p. 52.

${ }^{195}$ RIBEIRO, Patrícia Henriques. As Relações entre o Direito Internacional e o Direito Interno - conflito entre ordenamento brasileiro e normas do MERCOSUL. Belo Horizonte: Del Rey, 2001. p. 181.
} 
Sofovich. Ao decidir a lide em questão, o Tribunal argentino inovou ao estabelecer a superioridade dos tratados internacionais perante as leis federais, diferentemente da posição de igualdade hierárquica até então dominante ${ }^{196}$.

Esposando a nova posição jurisprudencial, a reforma constitucional de 1994 consagrou uma maior deferência legislativa aos tratados internacionais, por meio da nova letra do artigo 75, inciso 22, da Constituição Argentina, o qual dispõe que ao Congresso Nacional compete:

“22) Aprobar o desechar tratados concluidos con las demás naciones y con las organizaciones internacionales y con los concordatos com la Santa Sede. Los tratados y concordatos tienen jerarquía superior a las leyes".

Ademais, o mesmo item jurídico reconhece um tratamento diferenciado aos tratados que versem sobre matéria de Direitos Humanos, mostrando grande avanço legislativo neste campo:

"La Declaración Americana de los Derechos y Deberes del Hombre; la Declaración Universal de los Derechos Humanos; La Convención Americana de los Derechos Humanos; el Pacto Internacional de Derechos Civiles y Políticos y su Protocolo Facultativo; la Convención Internacional sobre la Eliminación de todas las Formas de Discriminación Racial; la Convención sobre la Eliminación de todas las formas de Discriminación contra la Mujer; la Convención contra la Tortura y otros Tratos o Penas Crueles, Inhumanos o Degradantes; la Convención sobre los Derechos del Niño; en las condiciones de su vigencia, tienen jerarquía constitucional, no derogan artículo alguno de la primera parte de esta Constitución y deben entenderse complementarios de los derechos y garantías para ella reconocidos".

Ao conceder hierarquia constitucional aos tratados internacionais, a Constituição Argentina invariavelmente dá origem a um novo bloco de constitucionalidade ${ }^{197}$, estabelecendo não apenas sua pronta vigência no ordenamento jurídico argentino, como também sua condição de norma superior, ao lado das disposições constitucionais previstas na

\footnotetext{
196 O referido autor, ainda a respeito do célebre caso, afirma que este: "inició el reconocimiento del orden supranacional en el derecho interno. Se resolvió en primer lugar que los tratados tienen jerarquía superior a las leyes federales, de modo que una ley posterior no puede modificar su contenido. En segundo lugar quedó establecido que el derecho que se invoca con fundamento en una norma internacional es directamente operativa, vale decir automáticamente exigible ante los tribunales locales. Por ultimo se dijo en esa sentencia que, cuando se trataba de la aplicación de un tratado internacional por parte de un tribunal de justicia, su resolución debía conformarse a la jurisprudencia de los órganos internacionales aplicados a la interpretación del instrumento internacional (en el caso la Corte Internacional del Derechos Humanos)", Cf. CONSTENLA, Carlos R. "Aplicación del derecho internacional de los derechos humanos por los tribunales de la República Argentina". In: Revista IIDH, n. 38, jul-dez 2003, p. 115.

197 Idem. loc. cit.
} 
Carta Magna ${ }^{198}$. Muitos destes tratados, como veremos, tratam direta ou indiretamente da educação básica, reforçando as disposições normativas argentinas para o exercício e proteção do correspondente direito.

A Carta argentina ainda determina que a denúncia destes tratados selecionados, por parte do Poder Executivo, requer aprovação das duas Casas Legislativas nacionais, em quorum qualificado de dois terços da totalidade dos membros de cada Câmara. Já os demais tratados internacionais sobre Direito Humanos deverão obter voto de dois terços da totalidade dos membros de cada Câmara para adquirir status constitucional ${ }^{199}$.

Por fim, ainda outra vez inovou o poder constituinte derivado argentino, ao estabelecer a competência das províncias para a celebração de tratados internacionais, pelo disposto no artigo 124, incorporado pela reforma constitucional de 1994. Essa faculdade, no entanto, está condicionada à compatibilidade do tratado com a política externa argentina, com as faculdades delegadas ao governo federal e com o crédito público da Nação ${ }^{200}$.

\section{$\underline{2.3 .2-\text { Brasil }}$}

A Constituição brasileira de 1988 , posto que tenha apontado em seu art. $4^{\circ}$, parágrafo único, a integração dos povos latino-americanos como princípio norteador de sua política externa, é bastante lacônica no que tange a integração dos tratados internacionais ao ordenamento jurídico nacional. Este silêncio constitucional tem produzido discussões infindáveis a respeito da hierarquia dos tratados internacionais no plano interno brasileiro, ensejando inclusive a promulgação de uma emenda constitucional, a qual, infelizmente, não conseguiu resolver cabalmente a questão.

A redação original da Constituição Brasileira de 1988, em seu artigo $5^{\circ}$, parágrafo $2^{\circ}$, apresentava os seguintes termos:

\footnotetext{
${ }^{198}$ Cumpre mencionar que ao mencionar "en las condiciones de su vigencia”, o constituinte argentino procurava respeitar as regras estabelecidas pela Convenção de Viena sobre o Direito dos Tratados, a qual já apresentamos. 199 Art. 75, inciso 22 da Constituição Argentina.

${ }^{200}$ ABSI, Luis Alberto. op. cit. p. 52. Também, RIBEIRO, Patrícia Henriques. op. cit. p. 188-189.
} 
$\S 2^{\circ}$ - Os direitos e garantias expressos nesta Constituição não excluem outros decorrentes do regime e dos princípios por ela adotados, ou dos tratados internacionais em que a República Federativa do Brasil seja parte.

Desta feita, depreende-se do texto constitucional que aos direitos fundamentais erigidos no artigo $5^{\circ}$ somar-se-ão direitos e garantias decorrentes dos tratados internacionais em que o país for parte. Entretanto, não há menção expressa à hierarquia normativa dos tratados internacionais, uma vez incorporados ao ordenamento nacional. Diante do silêncio constitucional, a decisão final da questão recai invariavelmente sobre o Supremo Tribunal Federal.

A partir de acurado estudo da matéria, Pedro Dallari assevera que a posição dominante na corte constitucional consagrou o

\begin{abstract}
"entendimento de que, no plano da hierarquia das normas jurídicas, o tratado equipara-se à lei interna, tomada em seu sentido estrito, prevalecendo em face da lei que lhe proceder, mas tendo sua eficácia afastada pela que lhe suceder (critério da norma mais recente), ou, então, se dotado do atributo da especialidade, prevalecendo em face da lei de abrangência geral, mas sendo superado, se norma geral, por aquela de sentido especial (critério da especialidade)" ${ }^{, 201}$.
\end{abstract}

Sói identificar como leading case desta posição, o notório julgado RE 80.004-SE, cuja sentença, datada de 1977, discutia a aplicabilidade da Lei Uniforme sobre Letras de Câmbio e Notas Promissórias, tratado internacional promulgado em 1966, perante o DecretoLei n. 427/69. Diante de uma votação quase unânime ${ }^{202}$, estabeleceu-se o dualismo enquanto diretriz para o julgamento do STF, estampada na citação de Amílcar Castro, presente no voto do Ministro Cunha Peixoto:

“(...) tratado não é lei; é ato internacional, que obriga o povo considerado em bloco; que obriga o governo na ordem externa, e não o povo na ordem interna. Não é admissível que um só ato, ao mesmo tempo, possa ser tratado e ato legislativo ordinário; (...). O tratado explana relações entre governantes (horizontais, sendo as pessoas coordenadas), enquanto a lei e o decreto explicam relações de governo com seus súditos (verticais, entre subordinante e subordinados)". ${ }^{203}$

\footnotetext{
${ }^{201}$ DALLARI, Pedro B. A. op. cit. p. 87.

${ }^{202}$ Apenas o Ministro Xavier de Albuquerque apresentou voto contrário.

${ }^{203}$ CASTRO, Amílcar de. Direito Internacional Privado. vol. I. $3^{\text {a }}$ ed. Rio de Janeiro: Forense, 1977. p. 126.
} 
Crítico feroz da posição jurisprudencial brasileira a respeito dos tratados internacionais, Celso D. Albuquerque Mello vocifera:

\begin{abstract}
"O atraso brasileiro é monumental (...). A tendência mais recente no Brasil é a de um verdadeiro retrocesso nessa matéria. (...) A grande maioria dos votos está fundamentada em autores antigos e dualistas, como é o caso de Triepel. Sustentar que a nossa Constituição é omissa nessa matéria significa apenas que a jurisprudência passa a ter um papel mais relevante, mas não que a jurisprudência possa ignorar a tendência atual do direito nesta matéria, adotando uma concepção de soberania que desapareceu em 1919 (...). Na verdade, o STF errou e não tem coragem de corrigir (....). De agora em diante, o STF fará remendos desse tipo. A decisão é das mais funestas, vez que o STF não viu a consequiência de seu acórdão, que poderá influenciar os juízes nos mais diferentes locais do Brasil. Por outro lado, faltou a ele sensibilidade para o momento atual em que o Brasil intensifica as relações internacionais. Qual o valor de um tratado se um dos contratantes, por meio de lei interna, pode deixar de aplicá-lo? Se o STF considera que as convenções do direito uniforme estão ultrapassadas, cabe ao Executivo denunciá-las no procedimento fixado por elas mesmas, mas não ao STF."204
\end{abstract}

Apesar do inconformismo com relação à posição jurisprudencial tida como retrógrada, Pedro Dallari, valendo-se dos ensinamentos de Jacob Dolinger, demonstra que não houve de fato um retrocesso, vez que se tratava de posição corrente da Corte, excetuando-se apenas os casos envolvendo tratados de extradição e matéria tributária ${ }^{205}$.

Contudo, não se pode qualificar como inerte o legislador brasileiro. Por meio da Emenda Constitucional 45/2004, acresceu dois novos parágrafos ao artigo $5^{\circ}$ da Constituição, sendo que o $\S 3^{\circ}$ disciplina a matéria de integração dos tratados de direitos humanos ${ }^{206}$. Diz a letra da lei:

$\S 3^{\circ}$ Os tratados e convenções internacionais sobre direitos humanos que forem aprovados, em cada Casa do Congresso Nacional, em dois turnos, por três quintos dos votos dos respectivos membros, serão equivalentes às emendas constitucionais.

\footnotetext{
${ }^{204}$ MELLO, Celso D. de Albuquerque. Curso de Direito Internacional Público. $11^{a}$ ed. rev. e ampl. Rio de Janeiro: Renovar, 1997. p. 112.

205 DALlARI, Pedro B. A. op. cit. p. 57. O autor também apresenta uma interessante proposta para a constitucionalização das regras de integração entre o ordenamento internacional e nacional, por meio da adoção de três parágrafos ao artigo $4^{\circ}$ da Constituição, com a seguinte redação: "§ $1^{\circ}$ - As normas gerais e princípios de Direito Internacional Público são parte integrante do direito interno"; " $\$ 2^{\circ}$ - Os tratados internacionais em que a República seja parte integram o ordenamento jurídico nacional e as suas normas sobrepõem-se às das leis nacionais"; e, " $\$ 3^{\circ}$ - As normas emanadas dos órgãos competentes das organizações internacionais de que a República Federativa do Brasil seja parte vigoram na ordem interna, desde que expressamente estabelecido nos respectivos tratados constitutivos", Cf. Idem. op. cit. p. 123-149.

${ }^{206}$ Apenas a título de informação, o $§ 4^{\circ}$ do artigo $5^{\circ}$ trata da submissão brasileira à jurisdição do Tribunal Penal Internacional.
} 
Primeiramente, cumpre observar que a introdução do $\S 3^{\circ}$ coaduna-se com a pretensão constitucional de primar pela prevalência dos direitos humanos enquanto princípio das relações exteriores brasileiras ${ }^{207}$. Todavia, à inserção infelizmente não foi possível encerrar a discussão doutrinária e jurisprudencial acerca da integração jurídica dos tratados internacionais de direitos humanos, promovendo, na verdade, ainda maiores discussões com relação à extensão da constitucionalidade destes.

A respeito do $\S 3^{\circ}$, Celso Lafer defende que a inclusão deste não corresponde a uma lei interpretativa do $\S 2^{\circ}$. Tomando por base em sua análise a prevalência dos direitos humanos como fundamento das relações internacionais do Brasil, identifica uma clara deferência normativa aos direitos humanos, que gozariam, de fato, de um status constitucional diferenciado ${ }^{208}$.

Para o autor, a inovação do $\S 3^{\circ}$ está no reconhecimento de que o tratado internacional de direitos humanos, uma vez ratificado pelo Brasil mediante procedimento de aprovação legislativa definida em seu texto, será considerado formalmente constitucional e não apenas materialmente $^{209}$. Por esse entendimento, estende-se o bloco de constitucionalidade não apenas aos direitos e garantias previstos nos tratados internacionais, mas também a todo o texto do diploma internacional em questão.

Não obstante o $\S 3^{\circ}$ prever um rito especial para o sucesso da equiparação constitucional, Celso Lafer defende a formalidade constitucional também para os tratados de direitos humanos ratificados pelo Brasil antes da promulgação da Constituição de 1988, em razão da recepção prevista no $\S 2^{\circ}$. Na visão do autor, somente os tratados internacionais de direitos humanos promulgados durante a vigência constitucional até a Emenda 45/2004 não seriam formalmente constitucionais ${ }^{210}$.

\footnotetext{
${ }^{207}$ Constituição Brasileira, artigo $4^{\circ}$, inciso II.

208 LAFER, Celso. A Internacionalização dos Direitos Humanos: constituição, racismo e relações internacionais. São Paulo. Manole, 2005. p. 17.

${ }^{209}$ No mesmo sentido, PIOVESAN, Flávia. Direitos Humanos e o Direito Constitucional Internacional. São Paulo: Max Limonad, 2001. p. 73

${ }^{210}$ A esse respeito diz o autor: "pois foram como tais formalmente recepcionados pelo $\S 2^{\circ}$ do artigo $5^{\circ}$ não só pela referência nele contida aos tratados como também pelo dispositivo que afirma que os direitos e garantias expressos na Constituição não excluem outros decorrentes do regime e dos princípios por ele adotados. Neste sentido, aponto que a referência aos princípios pressupõe, como foi visto, a expansão axiológica do Direito na perspectiva ex parte civium dos direitos humanos", Cf. LAFER, Celso. op. cit. p. 16-17.
} 
Diferentemente, Flávia Piovesan acredita que todos os tratados de direitos humanos ratificados pelo Brasil antes da EC 45/2004, incluindo aqueles ratificados ao longo do período entre a promulgação da Constituição Brasileira e a referida emenda, são material e formalmente constitucionais:

\begin{abstract}
"uma vez mais, corrobora-se o entendimento de que os tratados internacionais de direitos humanos ratificados anteriormente ao mencionado parágrafo, ou seja, anteriormente à Emenda Constitucional n. 45/2004, têm hierarquia constitucional, situando-se como normas material e formalmente constitucionais. Esse entendimento decorre de quatro argumentos: a) a interpretação sistemática da Constituição, de forma a dialogar os $\S \S 2^{\circ}$ e $3^{\circ}$ do artigo $5^{\circ}$, já que o último não revogou o primeiro, mas deve, ao revés, ser interpretado à luz do sistema constitucional; b) a lógica e racionalidade material que devem orientar a hermenêutica dos direitos humanos; c) a necessidade de evitar interpretações que apontem agudos anacronismos da ordem jurídica; e d) a teoria geral da recepção do direito brasileiro" ${ }^{211}$
\end{abstract}

A questão, contudo, foi submetida à apreciação pelo STF por meio do Recurso Extraordinário 466.343/SP, que tratava de caso de prisão civil para depositário infiel, no plano de um contrato de alienação fiduciária. A prisão civil por dívida, frise-se, encontra guarida no artigo $5^{\circ}$, inciso LXVII da Constituição ${ }^{212}$. Apesar da expressa previsão constitucional, a discussão envolvia a aplicabilidade do Pacto de São José da Costa Rica sobre Direitos Humanos, ratificado pelo Brasil em 1992, o qual proíbe a prisão civil por dívida em seu artigo $7^{\circ}$, parágrafo $7^{\circ}$, excetuado o caso de devedor voluntário de pensão alimentícia.

Após longo julgamento, o plenário do STF decidiu, em 03 de dezembro de 2008, que o inciso constitucional não se aplica ao depositário infiel. Neste sentido, o voto do Ministro Relator Gilmar Mendes declara a infraconstitucionalidade dos tratados de direitos humanos não aprovados pelo rito do $\S 3^{\circ}$, porém reconhece seu caráter supralegal, de modo que a legislação infraconstitucional anterior perde eficácia perante esses diplomas internacionais. Ademais, estes prevalecem sobre a legislação infraconstitucional posterior. Afirma o Ministro em seu voto:

\begin{abstract}
"[p]arece que a discussão em torno do status constitucional dos tratados de direitos humanos foi, de certa forma, esvaziada pela promulgação da Emenda Constitucional n. 45/2004, (...) a qual trouxe como um de seus estandartes a incorporação do $\S 3^{\circ}$ ao artigo $5^{\circ}$ (...). Em termos práticos, trata-se de uma declaração eloqüente de que os tratados já ratificados pelo Brasil, anteriormente à mudança constitucional, e não
\end{abstract}

\footnotetext{
${ }^{211}$ PIOVESAN, Flávia. op. cit. p. 73

212 Diz o mencionado inciso: "LXVII - não haverá prisão civil por dívida, salvo a do responsável pelo inadimplemento voluntário e inescusável de obrigação alimentícia e a do depositário infiel”.
} 
submetidos ao processo legislativo especial de aprovação no Congresso Nacional, não podem ser comparados às normas constitucionais,"213.

Data venia, a guisa de conclusão, não concordamos com a decisão proferida pelo STF, a qual possui o condão de dirimir as questões envolvendo os tratados internacionais e o ordenamento infraconstitucional somente pela ótica da supralegalidade. Identificar os já ratificados tratados internacionais de direitos humanos como infraconstitucionais em razão de sua não aprovação pelo rito especial atenta diretamente à vigência do $\S 2^{\circ}$ do $\operatorname{artigo} 5^{\circ}$, responsável pela recepção constitucional dos direitos e garantias expressos nestes diplomas jurídicos internacionais, quando de sua ratificação. Outrossim, é inegável que tal interpretação ameaça sobremaneira a promoção do direito internacional à educação básica ratificado pelo país.

Por fim, cumpre informar que a Convenção Internacional sobre os Direitos das Pessoas com Deficiências foi recentemente aprovada pelo Decreto Legislativo n. 186, em 09 de julho de 2008 , respeitando-se o rito especial do $\S 3^{\circ}$ do artigo $5^{\circ}$. Até o presente momento, trata-se do único documento internacional aprovado nestes termos.

\subsection{3 - Paraguai}

A Constituição Paraguaia de 1992 dedica especial atenção à temática da integração dos tratados internacionais ao ordenamento jurídico nacional. O artigo 137 da Constituição Paraguaia estabelece que

\footnotetext{
"la ley suprema de la República es la Constitución. Esta, los tratados, convenios y acuerdos internacionales aprobados y ratificados, las leyes dictadas por el Congreso y otras disposiciones jurídicas de inferior jerarquía, sancionadas en consecuencia, integran el derecho positivo nacional en el orden de prelación enunciado".
}

Percebe-se, portanto, que o texto constitucional paraguaio é muito claro com relação à hierarquia normativa, situando os tratados internacionais, uma vez aprovados e ratificados,

\footnotetext{
${ }^{213}$ Trecho extraído do voto do Ministro Gilmar Mendes, proferido no Recurso Extraordinário 466.343/SP. Os destaques estão presentes no original. Votaram com o relator os Ministros: Menezes Direito, Marco Aurélio Mello, Enrique Ricardo Lewandowski e Cármen Lúcia. Por votarem pela constitucionalidade dos tratados internacionais de direitos humanos, foram parcialmente vencidos os Ministros: Cezar Peluso, Eros Grau, Ellen Gracie e Celso de Mello.
} 
abaixo apenas da Carta Magna nacional. Desta feita, destaca-se, pois, a sujeição da aplicabilidade e exigibilidade do tratado internacional à aprovação de lei específica por parte do Congresso paraguaio. ${ }^{214}$

O artigo 141 do mesmo diploma jurídico, em consonância com o artigo transcrito acima, versa acerca dos tratados internacionais já celebrados e com chancela parlamentar, afirmando que estes tratados gozam da mesma hierarquia normativa apresentada no artigo apresentado acima. $^{215}$

Contudo, insta ressaltar o especial apreço do constituinte paraguaio para com os tratados internacionais cuja matéria seja de Direitos Humanos, os quais somente podem ser denunciados pelo mesmo procedimento legislativo previsto para as emendas constitucionais, por força do artigo 142 da Constituição Paraguaia, que possui a seguinte redação:

\footnotetext{
"Los tratados internacionales relativos a los derechos humanos no podrán ser denunciados sino por los procedimientos que rigen para la enmienda de esta Constitución".
}

Desta forma, em que pese a sua não-equiparação jurídica às normas constitucionais paraguaias, concede-se uma forte estabilidade aos tratados internacionais sobre este tema específico. Diante do exposto, María Prujel conclui que se outorgou aos instrumentos internacionais de direitos humanos um caráter quase-constitucional. ${ }^{216}$

O constituinte paraguaio previu, igualmente, o reconhecimento de um ordenamento jurídico supranacional voltado para a vigência dos direitos humanos, paz, cooperação e desenvolvimento. Reza o artigo 145 da Constituição paraguaia:

\begin{abstract}
"La República del Paraguay, en condiciones de igualdad con otros Estados, admite um orden jurídico supranacional que garantice la vigencia de los derechos humanos, de la paz, de la justicia, de la cooperación y del desarrollo, en lo político, económico, social y cultural. Dichas decisiones sólo podrán adoptarse por mayoría absoluta de cada Cámara del Congreso"
\end{abstract}

\footnotetext{
${ }^{214}$ PRUJEL, María Elodia Almirón. op. cit. p. 36. A autora ainda nos ensina a respeito do procedimento de aprovação por parte do Congresso paraguaio, o qual se inicia pela apreciação realizada no Senado, por competência privativa exclusiva, passando-se em seguida à Câmara de Deputados, que atuará como instância revisora.

${ }^{215}$ Destarte, também se encontram acima das leis nacionais e abaixo apenas da Constituição nacional. Cuida o artigo 141 da Constituição Paraguaia de 1992: "Los tratados internacionales válidamente celebrados, aprobados por ley del Congreso e cuyos instrumentos de ratificación fueran canjeados o depositados, forman parte del ordenamiento legal interno con la jerarquía que determina el artículo 137”.

${ }^{216}$ Idem. op. cit. p. 37.
} 
Embora o texto constitucional paraguaio não faça nenhuma alusão expressa à delegação de competências e poderes a órgãos supranacionais de qualquer espécie, María Prujel antevê neste artigo a extensão da proteção dos direitos fundamentais ao plano internacional, uma vez que esta seja deficiente no âmbito interno, quando defendidos pelos mecanismos nacionais. $^{217}$

\section{$\underline{2.3 .4-\text { Uruguai }}$}

Como já mencionado anteriormente, a Constituição uruguaia de 1967 é a segunda mais antiga do bloco regional, perdendo apenas para sua contraparte argentina. Entretanto, assim como esta, sofreu extensas reformas ao longo dos últimos anos, mais precisamente em 1996 e 2004. Em que pesem as oportunidades, as reformas uruguaias não contemplaram uma maior atenção à temática da integração dos tratados internacionais, de forma que o texto constitucional uruguaio apenas prevê competências para a sua celebração e aprovação, omitindo-se a respeito da hierarquia das normas provenientes dos instrumentos jurídicos internacionais $^{218}$.

É interessante notar que a única inovação legislativa uruguaia no tocante aos tratados internacionais nas mencionadas reformas refere-se à adição, em 2004, da necessidade de cláusula arbitral ou outro meio pacífico de solução de controvérsia em todos os tratados internacionais celebrados pelo país, por força do artigo $6^{\circ}$ da Constituição:

\footnotetext{
"en los tratados internacionales que celebra la República pondrá la cláusula de que todas las diferencias que surjan entre las partes contratantes, serán decididas por el arbitraje u otros medios pacíficos. La República procurará la integración social y económica de los Estados Lationamericanos, especialmente en lo que se refiere a la defensa común de sus productos y materias primas. Asimismo, propenderá a la efectia complementación de sus servicios públicos"
}

\footnotetext{
${ }^{217}$ Idem. op. cit. p. 39.

${ }^{218}$ Posto que haja este silêncio constitucional, Alejandro Perotti nos ensina que o ordenamento jurídico infraconstitucional uruguaio recepciona acordos e princípios internacionais em seus diversos códigos, como o aduaneiro, aeronáutico, processual civil, processual penal, tributário, entre outros. Cf. PEROTTI, Alejandro Daniel. Habilitación Constitucional para la Integración Comunitaria - estudios sobre los Estados del Mercosur. t. II. Montevidéu: Konrad Adenauer, 2004. p. 414.
} 
Destarte, pode-se afirmar que, do ponto de vista normativo, trata-se da Constituição MERCOSULina mais retrógrada no que tange a integração do Direito Internacional Público ao ordenamento jurídico nacional. Não se encontra, outrossim, nenhuma referência especial aos tratados em matéria de Direitos Humanos.

Todavia, Alejandro Perotti advoga que os tratados internacionais possam influir diretamente na extensão do rol dos direitos, deveres e garantias previstas na Constituição Uruguaia, por meio da interpretação do artigo 72 desta Carta Magna ${ }^{219}$, o qual prevê que "la enumeración de derechos, deberes y garantías hecha por la Constitución, no excluye los otros que son inherentes a la personalidad humana o se derivan de la forma republicana de gobierno".

Diante deste silêncio constitucional, é natural que a temática seja analisada com maior liberdade pela jurisprudência uruguaia. Conforme nos ensina Heber Arbuet Vignali e Jean Michel Arrighi, não impediu a Suprema Corte de Justiça uruguaia de reiterar, salvo algumas exceções, a primazia de normas provenientes de tratados internacionais sobre normas nacionais contrárias, ainda que posteriores, revelando sua deferência para com o Direito Internacional Público. ${ }^{220}$

Alejandro Perotti, por sua vez, critica a jurisprudência uruguaia por não haver constituído, em seu entender, uma posição consolidada a respeito do tema da integração dos tratados internacionais e sua relação com o direito interno uruguaio ${ }^{221}$. A partir de um longo estudo jurisprudencial, o mencionado autor coleciona casos em que houve o reconhecimento de uma necessária recepção dos acordos internacionais, bem como outros que atestam a vigência imediata dos tratados internacionais ${ }^{222}$. Desta feita, conclui o autor que

\footnotetext{
${ }^{219}$ Idem. op. cit. p. 415.

${ }^{220}$ Apud DALLARI, Pedro B.A. op. cit. p. 40.

${ }^{221}$ Afirma o autor que "la claridad de la cuestión (...) contrasta con los reiterados vaivenes de la jurisprudencia, al punto tal que resulta difícil, aún en la actualidad, caracterizarla como defensora del monismo o apegada al dualismo", Cf. PEROTTI, Alejandro Daniel. op. cit. p. 421.

${ }^{222}$ Destaca-se o caso intitulado "M.I. c/C.S.A.”, julgado pelo $5^{\circ}$ turno do Tribunal de Apelações Civis, em 31 de maio de 1988, com a seguinte redação: "[e]l Convenio de Paris es un verdadero tratado internacional, parte integrante del orden jurídico interno, de aplicabilidad directa en la dilucidación de la litis (...) las disposiciones del art. 6 bis y del art. 9 [de la Convención] relativas a las 'marcas notoriamente conocidas' y al 'nombre comercial' deben calificarse como autoejecutivas susceptibles de aplicación directa, sin necesidad de reglamentación especial", Cf. Apud Idem. op. cit. p. 426. Em sentido contrário, o caso intitulado "Colina/CUTSA" (n. 737/95), cuja decisão da Suprema Corte afirma que "[e]l Convenio Internacional del Trabajo n. 132 fue ratificado por el Decreto-Ley n. 14.568 y es ese acto legislativo y no el convenio en sí, el que le da el valor y fuerza de ley al texto del mismo. No se trata, en la especie, de aplicar directamente el Convenio
} 
“(...) la tendencia en el poder judicial uruguayo es reconocer los postulados de la escuela monista, en lo que hace al relacionamiento entre el derecho internacional y el derecho nacional. Los jueces, no obstante los giros doctrinales apuntados, se inclinan por la aplicación inmediata de la normativa externa, principalmente en lo que se refiere al derecho consuetudinario, al derecho nacido a cobijo de la OIT, a las clausulas de los tratados de derechos humanos, y a las disposiciones de los tratados de integración incluyendo los acuerdos aprobados en su marco"223.

Contudo, em caso de conflito entre a norma oriunda de tratado internacional e a legislação constitucional uruguaia, o autor aponta que

\begin{abstract}
“(...) la jurisprudencia defiende en toda su plenitud la supremacía del ordenamiento constitucional aún contra las disposiciones contenidas en un tratado internacional. Lo relevante no es el origen de la normativa sino la ubicación jerárquicamente superior de la Carta, la cual se sobrepone, en última instancia, a todo el derecho aplicable en la sede interna, sea éste nacional o internacional"224.
\end{abstract}

Especialmente com relação aos tratados internacionais de direitos humanos, a jurisprudência uruguaia, na visão de Alejandro Perotti, tem consolidado a posição de aplicabilidade direta das normas internacionais, assim como da jurisprudência assentada pelos tribunais internacionais encarregados de sua interpretação ${ }^{225}$. Estas normas, ademais, teriam recebido status constitucional na interpretação da Suprema Corte uruguaia, conforme atesta julgado a respeito da aplicabilidade da Convenção sobre os Direitos da Criança ${ }^{226}$, cujo texto se reproduz a seguir:

\begin{abstract}
"[e]l derecho a la identidad del menor tiene en la Argentina jerarquía de ley fundamental (art. 75, n. 22); en nuestro país también cabe similar solución por la incidencia que tiene el art. 72 de la Constitución, que permite recepcionar todos los derechos humanos que se consagran - más específicamente - en las Convenciones o Pactos Internacionales,227
\end{abstract}

Desta feita, pode-se concluir que a discussão acerca da integração e aplicabilidade dos tratados internacionais no ordenamento uruguaio é debilitada pela omissão constitucional correspondente, o que abre espaço para uma larga produção jurisprudencial a respeito do tema, muitas vezes contraditória. Entretanto, os estudos jurisprudenciais aqui colacionados

(preeminencia o no de la ley internacional sobre la interna) sino de ver qué valor tiene ese C.I.T aprobado por ley del país y en ese sentido y por función de su incorporación al derecho interno, por voluntad legislativa, constituye derecho directamente aplicable que deroga, tácitamente, las normas legislativas anteriores que no se concilien (art. 10, C. Civil)", Cf. Apud Idem. op. cit. p. 423.

${ }^{223}$ Idem. op. cit. p. 432.

${ }^{224}$ Idem. op. cit. p. 471.

${ }^{225}$ Idem. op. cit. p. 429.

${ }^{226}$ Esta Convenção será estudada mais detidamente no próximo item de nosso estudo.

${ }^{227}$ Sentença n. 418/97 da Suprema Corte Uruguaia, parágrafo $11^{\circ}$, Apud Idem. op. cit. p. 471. 
denotam uma importante deferência concedida aos tratados internacionais de direitos humanos, dentre os quais se inserem aqueles que versam sobre o direito à educação básica.

\subsection{5 - Quadro Comparativo}

Antonio Cassese procede a um interessante estudo de classificação das formas pelas quais as Constituições se relacionam com o Direito Internacional, sugerindo, ao final, a classificação em quatro grupos distintos:

\footnotetext{
"A survey of modern constitutions permits us to conclude that they fall roughly into four groups: (1) those which do not say anything about the implementation of international treaties; (2) those which establish that treaty obligations must be complied with by all citizens and officials within the State, but do not grant treaties higher status than ordinary legislation; (3) those which take a step forward and lay down the principle that treaties prevail over statutes, with the consequences that national law makers cannot alter or supersede the provisions of treaties the provisions of treaties by enacting new law; and (4) those which go to extreme of allowing treaties to modify or revise constitutional provisions,"228
}

Cassese ainda aponta que a imensa maioria dos textos constitucionais ao redor do mundo recai na primeira categoria, a qual, em conjunto com a segunda, expressa uma postura constitucional mais voltada para aspirações nacionalistas ${ }^{229}$. Dentre os países estudados, felizmente apenas o Uruguai se insere nesta categoria, ressalvado o fato de que o Brasil recentemente adotou a possibilidade de distinção aos tratados de direitos humanos. A partir das últimas reformas constitucionais, pode-se dizer que Paraguai e Argentina estão contidos no terceiro grupo, sendo que esta última estabelece a constitucionalidade de uma série de tratados internacionais de direitos humanos.

A fim de possibilitar um estudo comparado didático da integração jurídica dos tratados internacionais ao ordenamento interno dos Estados-membros do MERCOSUL, apresentamos o quadro abaixo, com a finalidade de reproduzir sucintamente o confronto dos dados colhidos ao longo do estudo apresentado neste item:

\footnotetext{
${ }^{228}$ CASSESE, Antonio. "Modern Constitutions and International Law". In: Recueil des Cours de l'Académie de Droit International de la Haye, 1985 III, tomo 192, Dordrecht: Martinus Nijhoff Publishers, 1986. p. 394.

${ }^{229}$ Idem. op. cit. p. 394-395.
} 
Q.17 - Integração Jurídica dos Tratados Internacionais nas Constituições do MERCOSUL ${ }^{230}$

\begin{tabular}{|c|c|c|}
\hline País & $\begin{array}{l}\text { Hierarquia de Integração do } \\
\text { Tratado Internacional }\end{array}$ & $\begin{array}{l}\text { Existe tratamento diferenciado para os } \\
\text { Tratados de Direitos Humanos? }\end{array}$ \\
\hline Argentina & $\begin{array}{c}\text { hierarquia superior às leis } \\
(\text { art.75, 22) }\end{array}$ & $\begin{array}{c}\text { Sim - quanto à hierarquia } \\
(\text { art.75, 22) }\end{array}$ \\
\hline Brasil & omissão constitucional & $\begin{array}{l}\text { Sim - quanto à hierarquia } \\
\left(\operatorname{art.} 5^{\circ}, \text { par. } 2^{\circ} \text { e } 3^{\circ}\right)\end{array}$ \\
\hline Paraguai & $\begin{array}{l}\text { hierarquia superior às leis } \\
\text { (art.137) }\end{array}$ & $\begin{array}{c}\text { Sim - quanto à denúncia } \\
\text { (art.142) }\end{array}$ \\
\hline Uruguai & omissão constitucional & Não \\
\hline
\end{tabular}

Depreende-se desta análise comparada, a acentuada assimetria existente entre os Estados-membros do MERCOSUL no que tange o tema. Enquanto Argentina e Paraguai elucidam constitucionalmente a questão da hierarquia dos tratados internacionais, o silêncio das Cartas de Brasil e Uruguai engendra um longo debate doutrinário e jurisprudencial acerca do status dos documentos internacionais, o que acarreta sério entrave jurídico - e político - à tutela dos direitos e garantias previstas nos diplomas de Direito Internacional Público.

A despeito das inúmeras reformas constitucionais conduzidas nos últimos vinte $\operatorname{anos}^{231}$, nota-se relativa inércia do legislador brasileiro e uruguaio quanto ao tratamento da matéria, de modo que as omissões presentes nas respectivas Cartas Magnas geram graves incertezas jurídicas quanto à validade ou não de norma de tratado internacional perante lei nacional contrária, ou mesmo posterior.

Ademais, verifica-se nos países do bloco - à exceção do Uruguai - uma louvável deferência constitucional, sobretudo argentina, aos tratados internacionais em matéria de

\footnotetext{
${ }^{230}$ Os artigos referidos nesta tabela dizem respeito ao locus constitucional que tutela a matéria.

${ }^{231}$ A esse respeito, escreve Pedro Dallari: "com efeito, nas duas décadas finais do século XX, mudanças de natureza política em várias partes do planeta tiveram entre seus efeitos a intensificação de processos de integração internacional, e, no mundo ocidental, esse incremento se materializou, inclusive, em reformas dos sistemas constitucionais estatais, que passaram a contemplar mais objetivamente a disciplina jurídica da recepção e integração dos tratados", Cf. DALLARI, Pedro. op. cit. p. 24.
} 
Direitos Humanos, o que traduz tendência crescente no mundo contemporâneo ${ }^{232}$. Nas palavras de María Prujel, essa tendência é traduzida da seguinte forma:

\begin{abstract}
"La nueva tendencia en la integración del derecho se ve reflejada en los siguientes elementos: aceptación de la diferencia entre tratados internacionales tradicionales y tratados sobre derechos humanos; reconocimiento de la supremacía en los tratados sobre derechos humanos frente a las leyes nacionales y aún la misma jerarquía constitucional en las nuevas constituciones americanas; implementación de la compatibilización del derecho en leyes internas; existencia de límites establecidos a los poderes que integran el Estado en salvaguarda de los derechos y garantías y su efectividad",233
\end{abstract}

Ainda sobre o assunto, Cynthia Feldmann assevera que a recepção constitucional do direito internacional dos direitos humanos permite a uma dupla responsabilização do Estado em caso de violação, uma vez que esta se transveste de inconstitucionalidade e ilícito internacional, o que inegavelmente reforça sobremaneira a eficácia da proteção aos direitos humanos e, dentre eles, o direitos à educação básica. ${ }^{234}$

Podemos dizer que esta tendência confirma-se na Constituição Brasileira, com a introdução do $\S 3^{\circ}$ em seu artigo $5^{\circ}$. Saliente-se, outrossim, que a jurisprudência uruguaia, diante do silêncio constitucional a respeito da integração dos tratados, tem concedido um status constitucional àqueles que versam sobre direitos humanos, o que mitigaria a omissão da Letra Maior nesse país.

\title{
2.4 - Documentos Internacionais sobre o Direito à Educação Básica
}

Com este item, objetivamos demonstrar o gradual desenvolvimento dos documentos internacionais - tratados e declarações - sobre o direito à educação básica, de modo a contemplar não apenas a extensão normativa deste direito, bem como os compromissos políticos assumidos pelos Estados no plano global e continental. Ainda acerca do fenômeno da proteção jurídica internacional perante a nacional, Cynthia Feldmann esclarece que:

\footnotetext{
${ }^{232}$ Estes tratados especiais serão analisados de forma detida e pormenorizada ao longo do próximo item.

${ }^{233}$ PRUJEL, María. op. cit. p. 33

${ }^{234}$ FELDMANN, Cynthia González. op. cit. p. 20.
} 


\begin{abstract}
"Si bien el principio pacta sunt servanda se aplica en el derecho internacional en general, adquiere mayor relevancia en materia del DIDH, donde los tratados no solo significan ampliar el catálogo interno de derechos y garantías, sino aplicarlos efectivamente. Implica para el Estado obligaciones concretas acerca del modo en que se ejercen todas las atribuciones del poder para favorecer al individuo en el ejercicio pleno de sus derechos y libertades fundamentales. A la vez, desde el ámbito internacional se crean mecanismos de supervisión sobre el cumplimiento de las obligaciones internacionales contraídas libremente por los Estados. Estos mecanismos de supervisión adquieren formas de informes periódicos, procedimientos confidenciales, hasta procesos judiciales y cuasi judiciales, ${ }^{, 235}$
\end{abstract}

Iniciaremos nossa análise da extensão normativa internacional por meio da apresentação dos principais tratados que cuidam diretamente da educação básica e possuem o condão de responsabilizar internacionalmente os Estados perante a comunidade internacional e os seus nacionais.

Num segundo momento, a partir do entendimento de que os direitos humanos consagrados na DUDH devem ser interpretados à luz das desigualdades materiais e formais inerentes aos diversos grupos populacionais constituintes do gênero humano, dedicaremos um primeiro momento ao fenômeno da especialização dos direitos humanos. Neste sentido, analisaremos os principais documentos internacionais que, visando à defesa dos direitos humanos de determinadas parcelas da sociedade, asseguram o direito à educação básica. Concentrar-nos-emos especialmente sobre a Convenção sobre os Direitos da Criança, tratado internacional com o maior número de ratificações na história, e seus desdobramentos.

Por último, passaremos às declarações internacionais que, com muita ousadia, tem instado os governos a assumirem compromissos cada vez mais ousados na promoção da universalização da educação básica.

\title{
2.4.1 - Principais Tratados Internacionais Referentes à Educação Básica
}

Os principais tratados internacionais que discorrem sobre os direitos sociais - aí incluídos o direito à educação básica - são: no plano universal, o Pacto Internacional de Direitos Econômicos, Sociais e Culturais; e, no plano continental, o Protocolo Opcional à

\footnotetext{
${ }^{235}$ FELDMANN, Cynthia González. "La implementación de los tratados internacionales de derechos humanos por el Paraguay". In: FELDMANN, Cynthia González (org.). El Paraguay frente al Sistema Internacional de los Derechos Humanos. Konrad Adenauer: Montevidéu, 2004. p. 24.
} 
Convenção Americana de Direitos Humanos (Protocolo San Salvador). Estudaremos ambos a seguir:

a) Pacto Internacional de Direitos Econômicos, Sociais e Culturais (ONU)

A Comissão de Direitos Humanos da ONU, a qual já trabalhara na elaboração da DUDH, recebeu, em 1950, a incumbência de preparar um tratado internacional sobre direitos humanos, tendo em vista que a mencionada declaração não possui efeito vinculante e, portanto, obrigatoriedade jurídica perante os países signatários. Contudo, em meio ao contexto político e econômico da Guerra Fria, a tarefa de consignar num único documento um rol tão extenso de direitos se mostrou hercúlea, sobretudo em razão da clivagem ideológica que era o mote das relações internacionais no período:

\begin{abstract}
"Cabe ressaltar que essa separação dos direitos humanos em dois pactos diferentes fez parte da lógica de um momento histórico marcado por disputas ideológicas, quando o bloco socialista defendia a primazia dos direitos econômicos, sociais e culturais, os quais exigiam obrigações positivas do Estado, ou seja, representavam os direitos de aplicação progressiva. Diferentemente, o bloco capitalista defendia a maior importância dos direitos civis e políticos representados por aqueles de aplicação imediata que exigiam uma obrigação de abstenção do Estado",236.
\end{abstract}

Da dicotomia que se produziu, nascem os dois tratados internacionais que regulam os direitos humanos, ambos datados de 1966: o Pacto Internacional sobre os Direitos Civis e Políticos - PIDCP e o Pacto Internacional sobre Direitos Econômicos, Sociais e Culturais PIDESC. Na visão de Soledad Biedermann, a reunião dos dois tratados internacionais sobre os direitos humanos, assim como dos mecanismos de supervisão internacional ali contidos, cria "una verdadera Carta Internacional de Derechos Humanos". 237

Cumpre mencionar que se a categorização dos direitos humanos representou um atalho político indispensável para a consagração no plano internacional, pode-se afirmar que essa separação se encontra hoje superada, por meio dos textos finais das Conferências

\footnotetext{
${ }^{236}$ MARRUL, Indira Bastos. "O Fortalecimento da Indivisibilidade dos Direitos Humanos no Sistema Interamericano: efetiva garantia para o direito à educação". In: Revista IIDH, vol. 36, jul-dez 2002, p. 44. Alberto do Amaral Júnior sustenta que a opção da Comissão pela separação dos documentos ocorreu logo em 1951 e a conclusão da primeira redação se deu em 1954, quando se iniciaram as consultas aos diferentes governos, Cf. AMARAL JÚNIOR, Alberto do. op. cit. p. 443.

${ }^{237}$ BIEDERMANN, Soledad Villagra. "El Sistema Universal de Derechos Humanos: los mecanismos convencionales y los mecanismos basados en la Carta". In: FELDMANN, Cynthia González (org.). El Paraguay frente al Sistema Internacional de los Derechos Humanos. Konrad Adenauer: Montevidéu, 2004. p. 145.
} 
Mundiais de Direitos Humanos em Teerã e Viena, reprodutores de uma visão de indissociabilidade entre os direitos humanos. Em razão do propósito do nosso estudo, contudo, concentraremos nossa análise apenas no PIDESC, adotado pela Resolução $\mathrm{n}^{\circ} 2.220$ A, da Assembléia Geral das Nações Unidas, em 16.12.1966.

Não obstante o esforço de quase vinte anos para a assinatura do documento, foi necessária ainda outra década para que chegasse ao número de trinta e cinco depósitos de instrumentos de ratificação para que o tratado internacional pudesse entrar em vigor, o que ocorreu em 03.01.1976. Atualmente, o PIDESC conta com 160 Estados-Partes.

Em linhas gerais, o PIDESC estabelece com maior precisão jurídica as disposições contidas na DUDH, além de conter um rol mais amplo de direitos. Tradicionalmente, os Estados-Partes enviam relatórios periódicos relatando as implementações dos direitos previstos no documento. Não previsto originalmente no texto do tratado, o Comitê de Direitos Econômicos, Sociais e Culturais, composto por dezoito especialistas, nasce de uma resolução posterior do Conselho Econômico e Social da ONU. Note-se, que não há nenhuma previsão expressa no PIDESC que permita ao Comitê receber denúncias interestatais ou individuais em razão de eventual violação dos direitos ali consagrados. Tal situação ensejou o preparo de um Protocolo Opcional ao PIDESC, o qual foi aberto para assinaturas em 24 de setembro de 2009 e atualmente conta com trinta e duas assinaturas ${ }^{238}$.

O tema do direito à educação encontra-se concentrado nos artigos 13 e 14 do PIDESC, que se encontram na terceira parte do documento. O parágrafo primeiro do artigo 13 é extremamente claro é preciso quanto aos sujeitos do direito à educação, bem como enuncia suas finalidades:

"1. Os Estados-Partes do presente Pacto reconhecem o direito de todos à educação.
Concordam que a educação deve ser direcionada para o completo desenvolvimento
da personalidade humana e do sentido de sua dignidade, e devem fortalecer o respeito
pelos direitos humanos e liberdades fundamentais. Concordam ainda que a educação
deve capacitar todas as pessoas a participar efetivamente numa sociedade livre,
promover a compreensão, tolerância e a amizade entre todas as nações e entre todos

${ }^{238}$ Dos países aqui estudados, apenas o Brasil ainda não realizou a assinatura do mencionado Protocolo Opcional. Enquanto Uruguai e Argentina o fizeram na mesma data em que foi colocado à disposição, ou seja, em 24.09.2009, o Paraguai firmou o protocolo no dia 06.10.2009. Conforme disposto no protocolo, este somente entrará em vigor após o depósito do instrumento de ratificação de dez países signatários. 
os grupos raciais, étnicos ou religiosos, além das atividades das Nações Unidas para a manutenção da paz"239.

Para a consecução deste intento, em especial atenção à educação básica, o parágrafo segundo do mencionado documento proclama que a educação primária (Cine 01) deve ser compulsória e gratuitamente disponível a todos. A educação secundária (Cine 02 e 03), a qual complementaria o ciclo da educação básica, também foi prevista no documento. Para este nível de ensino previu-se sua disponibilidade e acessibilidade a todos, por todos os meios apropriados, sendo que, em particular, estimula-se a progressiva introdução da educação gratuita.

O artigo 14, por sua vez, vai mais além, ao determinar que todos os Estados-Partes do Pacto que, no momento de sua assinatura ou adesão ainda não tenham garantido em sua jurisdição a prestação da educação primária obrigatória e gratuita, devem elaborar, dentro de dois anos, um plano detalhado para gradualmente oferecê-la. Infelizmente, o artigo não previu um prazo máximo para a conformação dos Estados-Partes, limitando-se a mencionar que o plano deve fixar a sua meta "dentro de um número razoável de anos"240.

O PIDESC ainda trata da liberdade de ensino, assegurando-a por meio do respeito aos critérios mínimos estabelecidos pelos Estados-Partes ${ }^{241}$. Percebe-se, contudo, que o texto não especifica os requisitos entendidos como mínimos, de sorte que caberá aos Estados-Partes uma ampla liberdade na sua definição e, conseqüentemente, na sua tutela. Adiante, reconhece a liberdade parental na escolha da escola de seus filhos, bem como a liberdade de assegurar uma educação que reproduza suas convicções morais e religiosas para seus filhos ${ }^{242}$.

Por fim, é interessante mencionar que o PIDESC demorou muito para ser ratificado pela maioria dos Estados-membros do MERCOSUL, o que somente foi possível ao final dos regimes de ruptura democrática que vicejaram no subcontinente. A estreita ligação entre a

\footnotetext{
239 Tradução livre do texto original em inglês, cujo teor reproduzimos a seguir: "1. The States Parties to the present Covenant recognize the right of everyone to education. They agree that education shall be directed to the full development of the human personality and the sense of its dignity, and shall strengthen the respect for human rights and fundamental freedoms. They further agree that education shall enable all persons to participate effectively in a free society, promote understanding, tolerance and friendship among all nations and all racial, ethnic or religious groups, and further the activities of the United Nations for the maintenance of peace". Disponível em: http://www.un.org/millennium/law/iv-3.htm.

${ }^{240}$ Pacto Internacional dos Direitos Econômicos, Sociais e Culturais, art. 14.

${ }^{241}$ Pacto Internacional dos Direitos Econômicos, Sociais e Culturais, art. 13, parágrafo $4^{\circ}$.

${ }^{242}$ Pacto Internacional dos Direitos Econômicos, Sociais e Culturais, art. 13, parágrafo $3^{\circ}$.
} 
ratificação do tratado internacional e o fim das ditaduras militares fica ainda mais evidente no Paraguai, onde o PIDESC foi ratificado por meio da quarta lei promulgada no novo regime constitucional.

\section{Q. 18 - Pacto Internacional de Direitos Econômicos, Sociais e Culturais (ONU,}

16.12.1966)

\begin{tabular}{|c|c|c|c|}
\hline \multicolumn{1}{|c}{ País } & $\begin{array}{c}\text { Data de } \\
\text { Assinatura }\end{array}$ & Aprovação Legislativa & $\begin{array}{c}\text { Data de } \\
\text { Ratificação }\end{array}$ \\
\hline Argentina & 19.02 .1968 & Ley 23.313 de 17.04.1986 & 08.08 .1986 \\
\hline Brasil & Adesão & $\begin{array}{c}\text { Decreto Legislativo n }{ }^{\circ} 226, \text { de } \\
12.12 .1991^{244}\end{array}$ & 24.01 .1992 \\
\hline Paraguai & Adesão & Ley 4/92, de 10.09.1992 & 10.09 .1992 \\
\hline Uruguai & 21.02 .1967 & Ley 13.670 de 11.07.1969 & 01.04 .1970 \\
\hline
\end{tabular}

b) Convenção Americana sobre os Direitos Humanos e o Protocolo San Salvador

É interessante notar que no plano continental assistimos a uma repetição dos problemas jurídicos enfrentados pela falta de eficácia dos direitos humanos presentes nas primeiras declarações de direitos do homem no pós-guerra. Como vimos, a edição do Pacto Internacional dos Direitos Econômicos, Sociais e Culturais respondeu aos anseios pela responsabilização dos Estados no plano internacional, em caso de violação dos direitos ali consagrados. Da mesma forma, criou-se o consenso de que o plano continental carecia de um tratado internacional semelhante. Neste contexto surge a Convenção Americana sobre os

\footnotetext{
${ }^{243}$ Por data de ratificação se entende a data em que houve o depósito do instrumento de ratificação na organização respectiva, provocando a entrada do tratado internacional em vigor, independentemente do tipo de norma interna pela qual tenha sido aprovado. $\mathrm{O}$ artigo 27 , parágrafo $2^{\circ}$ do PIDESC determina uma prazo legal de três meses para o início da vigência para o Estado que ratificar ou aderir após o depósito do trigésimo quinto instrumento de ratificação ou adesão. Assim, por exemplo, considera-se a responsabilidade internacional do Brasil apenas a partir de 24.04.1992.

${ }^{244}$ Pela praxe brasileira, a Convenção foi promulgada pelo Decreto presidencial 591/90, de 06.07.1992. Ressalta Francisco Rezek que "o decreto de promulgação não constitui reclamo constitucional: ele é produto de uma praxe tão antiga quanto a independência e os primeiros exercícios convencionais do Império. Cuida-se de um decreto, unicamente porque os atos do chefe de Estado costumam ter esse nome", Cf. REZEK, Francisco. op. cit. p. 84.
} 
Direitos Humanos (CADH), mais conhecido como Pacto de San Jose da Costa Rica, firmado em 1969 e com vigência internacional a partir de 18.07.1978.

Ainda fortemente imbuída da clivagem ideológica típica do período da Guerra Fria, a CADH foi extremamente sucinta ao tratar dos direitos econômicos, sociais e culturais, dedicando-lhes apenas um artigo, reproduzido a seguir:

Artigo 26 - Desenvolvimento Progressivo

Os Estados-Partes comprometem-se a adotar providências, tanto no âmbito interno como mediante a cooperação internacional, especialmente a econômica e técnica, a fim de conseguir progressivamente a plena eficácia dos direitos que decorrem das normas econômicas, sociais e sobre educação, ciência e cultura, constantes da Carta da organização dos Estados Americanos, reformada pelo Protocolo Buenos Aires, na medida dos recursos disponíveis, por via legislativa ou por outros meios apropriados. $^{245}$

Ao final da Guerra Fria, cessaram as preocupações ideológicas continentais em torno de uma promoção dos direitos tidos como de segunda geração, os quais exigem prestações positivas por parte do Estado. Este é o espírito do Protocolo Adicional ao Pacto de San José da Costa Rica, também denominado Protocolo de San Salvador, adotado no XVIII Período Ordinário de Sessões da Assembléia Geral da Organização dos Estados Americanos (OEA), realizado na Cidade de San Salvador, El Salvador, em 17 de novembro de 1988.

O Protocolo, portanto, foi responsável por conferir maior detalhamento ao conteúdo dos direitos econômicos, sociais e culturais, permitindo o seu acompanhamento e monitoramento pela Comissão Interamericana de Direitos Humanos ${ }^{246}$. Em caso de violação, os Estados poderão levados a julgamento perante a Corte Interamericana de Direitos Humanos, órgão já previsto na Resolução XXXI, aprovada conjuntamente com a DADDH, mas estruturado apenas com a CADH. Nas palavras de Indira Marrul:

\footnotetext{
"A consolidação de uma base jurídica e o fortalecimento dos instrumentos criados para supervisionar o cumprimento das obrigações assumidas pelos Estados tem sido
}

\footnotetext{
${ }^{245}$ Texto em português retirado do anexo ao Decreto presidencial n.678, de 06.11.1992.

${ }^{246}$ Como exemplo deste acompanhamento realizado pela Comissão, Cynthia Feldmann relata: "La Comisión Interamericana de Derechos Humanos recomendó en el 2001 al Estado paraguayo: (...) Que se mejoren los servicios educativos y su calidad, respetando la diversidad cultural y haciendo efectivo el derecho a una educación primaria obligatoria y gratuita, incluyendo las medidas educativas necesarias para disminuir la tasa de deserción y el analfabetismo", Cf. FELDMANN, Cynthia. op. cit. p. 175.
} 
propulsores da evolução do Sistema Interamericano de Proteção e Promoção dos Direitos Humanos". 247

Acerca do direito à educação, o artigo 13 do Protocolo, seguindo o disposto na DADDH, enuncia a titularidade universal do direito à educação, além de enunciar as finalidades da educação, frisando a sua importância para a concretização da paz e da democracia $^{248}$. O artigo ainda se refere especificamente a cada nível de ensino:

3 - Os Estados-Partes neste Protocolo reconhecem que, a fim de conseguir o pleno exercício do direito à educação:

a) o ensino de primeiro grau deve ser obrigatório e acessível a todos gratuitamente;

b) o ensino de segundo grau, em suas diferentes formas, inclusive o ensino técnico e profissional, deve ser generalizado e acessível a todos, pelos meios que forem apropriados e, especialmente, pelo estabelecimento progressivo do ensino gratuito;

c) o ensino superior deve tornar-se igualmente acessível a todos, de acordo com a capacidade de cada um, pelos meios que forem apropriados e, especialmente, pelo estabelecimento progressivo do ensino gratuito;

d) deve-se promover ou intensificar, na medida do possível, o ensino básico para as pessoas que não tiverem recebido ou terminado o ciclo completo de instrução do primeiro grau;

e) deverão ser estabelecidos programas de ensino diferenciado para os deficientes, a fim de proporcionar instrução especial e formação a pessoas com impedimentos físicos ou deficiência mental. ${ }^{249}$

O parágrafo acima reproduz em grande medida o disposto no PIDESC, de modo que novamente apontamos a falta de ousadia dos Estados americanos diante da chance de aperfeiçoar o conteúdo do direito à educação básica. Repetindo novamente o PIDESC, os parágrafos $4^{\circ}$ e $5^{\circ}$ artigo 13 do Protocolo reconhecem ainda a liberdade dos pais na escolha da educação a ser ministrada para seus filhos e a liberdade de ensino, respeitada a legislação interna dos Estados-Partes.

Contudo, apesar de apenas reproduzir largamente o direito já previsto em outro documento internacional, é preciso reconhecer que a extensão da jurisdição da Corte Interamericana de Direitos Humanos concede uma nova dimensão à proteção destes direitos. Mesmo atuando após o esgotamento das vias recursais nacionais, a jurisprudência deste órgão tem cumprido papel importantíssimo na prestação de socorro àqueles cujos direitos são

\footnotetext{
${ }^{247}$ MARRUL, Indira Bastos. op. cit. p. 51.

${ }^{248}$ Protocolo Adicional ao Pacto de San José da Costa Rica, art. 13, parágrafos $1^{\mathbf{o}}$ e $2^{\circ}$.

${ }^{249}$ Texto em português retirado do anexo ao Decreto presidencial n.3.321, de 30.12.1999.
} 
transgredidos, inclusive se valendo de condenações de natureza pecuniária ${ }^{250}$. Cumpre mencionar que os Estados-Partes devem reconhecer previamente a competência da Corte para que possam ter averiguada sua responsabilidade por violação as normas continentais de proteção, o que foi feito por todos os países objetos do nosso estudo.

Por fim, apresentamos as ratificações do Protocolo Adicional, por meio de nosso habitual quadro:

Q. 19 - Protocolo Adicional da Convenção Americana sobre os Direitos Humanos em Matéria de Direitos Econômicos, Sociais e Culturais - Protocolo San Salvador (OEA, 1988)

\begin{tabular}{|c|c|c|c|}
\hline País & Data da Assinatura & Aprovação Legislativa & Data de Ratificação \\
\hline Argentina & 17.11 .1988 & Ley 24.658, de 19.06.1996 & 23.10 .2003 \\
\hline Brasil & Adesão & $\begin{array}{r}\text { Decreto Legislativo 56/95, } \\
\text { de 19.04.1995 }\end{array}$ & 21.08 .1996 \\
\hline Paraguai & 26.08 .1996 & Ley 1.040, de 16.04 .1997 & 03.06 .1997 \\
\hline Uruguai & 17.11 .1988 & Ley 16.519, de 12.07 .1994 & 02.04 .1996 \\
\hline
\end{tabular}

2.4.2 - A Proteção ao Direito à Educação Básica pela Via da Especificação dos Direitos $\underline{\text { Humanos }}$

Mencionamos no início deste capítulo que o marco inicial do regime internacional dos direitos humanos se deu com a Declaração Universal dos Direitos do Homem, aprovada no seio da Assembléia Geral das Nações Unidas, em 1948. Norberto Bobbio identifica na DDHU o encerramento e o início de processos distintos. Na medida em que desmente a visão

\footnotetext{
${ }^{250}$ A respeito da jurisprudência da Corte Interamericana, consultar PIOVESAN, Flávia. Direitos Humanos e Direito Constitucional Internacional. op. cit. p. 245 e ss.

${ }^{251}$ Promulgado pelo Decreto 3.321/99, de 30.12.1999.
} 
de que a positivação dos direitos humanos é prerrogativa particular dos Estados, reintroduz a noção de universalização da tutela destes direitos por via do plano normativo internacional ${ }^{252}$. Nesta medida, defende o autor que a DUDH deve ser entendida como o primeiro passo no sentido de ampliação e interpretação destes direitos de matizes históricos, o que enseja o processo de especialização dos direitos humanos no plano internacional ${ }^{253}$.

A identificação dos direitos assinalados ao "homem" pode conduzir ao equivocado entendimento de que estes direitos pertençam aos seres humanos enquanto ente genérico, portanto, indistintos entre $\mathrm{si}^{254}$. A questão a ser colocada é: se é certo que os direitos humanos estabelecem a dignidade mínima de todos os seres humanos, amalgamando, neste sentido, os conteúdos jurídicos para a sua promoção, como interagiriam perante grupos populacionais que demandam tratamentos desiguais, em virtude de suas especificidades?

Para o filósofo italiano, a resposta se encontra no complexo de normas internacionais de interpretação e extensão dos direitos humanos, as quais visam a cobrir os diferentes critérios de diferenciação do homem, como por exemplo, o sexo, a idade e a religião ${ }^{255}$. Ao tratar da especificação dos direitos humanos, Bobbio define que:

\footnotetext{
"Além dos processos de conversão em direito positivo, generalização e de internacionalização, aos quais me referi no início, manifestou-se nestes últimos anos uma nova linha de tendência, que se pode chamar de especificação; ela consiste na passagem gradual, porém cada vez mais acentuada, para um ulterior determinação dos sujeitos titulares de direitos". 256
}

Neste mesmo sentido, aos olhos de Katarina Tomasevski esta especialização representa, na verdade, a inclusão progressiva de grupos previamente excluídos da titularidade dos direitos humanos em um primeiro momento histórico:

\footnotetext{
"Cabe plasmar la historia de los derechos humanos por medio de dos círculos concéntricos que se van ampliando, en los que el primero reflejaría la extensión gradual de los derechos reconocidos y en el segundo la inclusión progresiva de todos los previamente excluidos. Los derechos que sólo se otorgaban antes a los hombres
}

\footnotetext{
${ }^{252}$ BOBBIO, Norberto. op. cit. p. 32.

${ }^{253}$ Idem. op. cit. p. 34.

${ }^{254}$ ARENDT, Hannah. op. cit. p. 230.

${ }^{255}$ BOBBIO, Norberto. op cit. p. 69.

${ }^{256}$ Idem. op. cit. p. 62.
} 
blancos, adultos y con una posición acomodada se han ido extendiendo gradualmente a las mujeres, luego a los adultos no blancos y posteriormente a los niños" ${ }^{\text {,257. }}$.

Podemos afirmar, portanto, que a criação da United Nations Internacional Children`s Emergency Fund (Fundo Internacional de Emergência das Nações Unidas para as Crianças UNICEF) inaugura a preocupação com a especificação dos direitos humanos no plano internacional. Criada, primeiramente, para auxiliar as crianças nos Estados assolados pela Segunda Guerra Mundial, transformou-se, em 1953, pela Resolução n. 802 da $8^{a}$ Assembléia Geral da ONU, em agência permanente e especializada para a assistência à infância nos países em desenvolvimento ${ }^{258}$.

A Declaração dos Direitos da Criança, por sua vez, consagra no plano normativo essa preocupação política dedicada às crianças. ${ }^{259} \mathrm{Em}$ direta sintonia com a DUDH, reforçada em seu preâmbulo, a Declaração dos Direitos da Criança foi aprovada pela Resolução n. 1386 ao

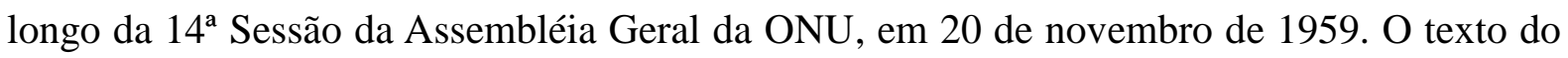
documento elenca dez princípios que deveriam nortear a atuação dos Estados, pais, responsáveis e sociedades na consecução de uma infância em melhores condições. A brevidade do texto, no entanto, esconde a densidade de seu conteúdo.

Ao mesmo tempo em promove uma defesa mais eficiente dos direitos humanos pela via da especialização, a Declaração dos Direitos da Criança reforça a importância do direito à educação, já elencado na DUDH. Em seu princípio de número sete, a Declaração delineia a gratuidade e compulsoriedade em seus níveis elementares, assim como a finalidade da educação ministrada:

A criança terá direito a receber educação, que será gratuita e compulsória pelo menos
nos níveis elementares. Será propiciada uma educação capaz de promover a sua
cultura geral e capacitá-la a, em condições de iguais oportunidades, desenvolver as
suas aptidões, sua capacidade de emitir juízo e seu senso de responsabilidade moral e
social, e a tornar-se um membro útil da sociedade. Os melhores interesses da criança
serão a diretriz a nortear os responsáveis pela sua educação e orientação; esta
responsabilidade cabe, em primeiro lugar, aos pais. A criança terá ampla
oportunidade para brincar e divertir-se, visando os propósitos mesmos da sua

${ }^{257}$ TOMASEVSKI, Katarina. “Contenido y Vigencia del Derecho a la Educación”. In: Revista IIDH, San José, v. 36, jul-dez 2002, p. 15. Também, BOBBIO, Norberto. op. cit. p. 71.

${ }^{258}$ ALVES, José Augusto Lindgren. op. cit. p. 51, nota 8.

${ }^{259}$ De fato alguns documentos internacionais anteriores já haviam concedido atenção especial à infância, como por exemplo, a Carta da Liga das Nações sobre a Criança, conhecida como Declaração de Genebra, datada de 1924. Todavia, aponta Marcos Neri de Almeida que esses documentos não reconheciam a criança enquanto sujeito de direito, identificando-a, na verdade, como mero receptor passivo da proteção que lhe era concedida, Cf. ALMEIDA, Marcos Neri. op. cit. p. 24-25. 
educação; a sociedade e as autoridades públicas empenhar-se-ão em promover o gozo deste direito $^{260}$.

Com efeito, a Declaração dos Direitos da Criança não possuía força vinculante típica dos tratados internacionais, servindo apenas como guia para atuação legislativa dos Estados. Inegavelmente, porém, seria a principal inspiração para a assinatura da Convenção sobre os Direitos da Criança, de 1989, a qual possui o condão de responsabilizar Estados-Partes que não respeitem os direitos e garantias previstos no tratado internacional, conforme veremos a seguir.

Seguiram-se à Declaração dos Direitos da Criança inúmeros tratados e declarações internacionais voltados para grupos populacionais específicos, como a Convenção Internacional sobre a Eliminação de Todas as Formas de Discriminação Racial, fïrmada em 1966, e a Convenção sobre a Eliminação de Todas as Formas de Discriminação contra Mulher, assinada em 1979. ${ }^{261}$ Ambos os documentos enunciam garantias educacionais aos seus tutelados, a partir da vedação à discriminação racial ${ }^{262}$ e de gênero ${ }^{263}$ no acesso ao ensino. Recentemente, a Convenção sobre os Direitos das Pessoas com Deficiências, datada de 2006, reafirmou o direito a uma educação inclusiva, por meio de uma educação primária gratuita $^{264}$.

$\mathrm{Na}$ verdade, todas essas convenções traduzem e reforçam a evidência da importância do fenômeno da especificação dos direitos humanos. Pois, se é certo que se destinam a grupos populacionais determinados, nada mais fazem que particularizar os efeitos jurídicos de norma internacional pré-existente, tanto na DUDH quanto na Convenção Relativa à Luta Contra a Discriminação no Campo do Ensino, tratado internacional adotado em 14 de

\footnotetext{
${ }^{260}$ Tradução livre do texto original em inglês, cujo teor se reproduz a seguir: "Principle 7 - The child is entitled to receive education, which shall be free and compulsory, at least in the elementary stages. He shall be given an education which will promote his general culture and enable him, on a basis of equal opportunity, to develop his abilities, his individual judgement, and his sense of moral and social responsibility, and to become a useful member of society. The best interests of the child shall be the guiding principle of those responsible for his education and guidance; that responsibility lies in the first place with his parents. The child shall have full opportunity for play and recreation, which should be directed to the same purposes as education; society and the public authorities shall endeavour to promote the enjoyment of this right".

${ }^{261}$ Ambas as Convenções foram assinadas e ratificadas por todos os Estados-membros do MERCOSUL.

${ }^{262}$ Convenção Internacional sobre a Eliminação de Todas as Formas de Discriminação Racial, art. $5^{\circ}$, "e".

${ }^{263}$ Convenção sobre a Eliminação de Todas as Formas de Discriminação contra Mulher, art. 10. Esta preocupação se repetiu no texto da Declaração de Beijing, firmada ao final da IV Cúpula Mundial sobre a Mulher, realizada em 1995. Este documento, em seu objetivo estratégico "b", reforça a preocupação pela equiparação do acesso entre meninos e meninas na educação básica, bem como a erradicação do analfabetismo entre as mulheres.

${ }^{264}$ Convenção sobre os Direitos das Pessoas com Deficiências, art. 24.
} 
dezembro de 1960. A Convenção estabelecia, em seu artigo $1^{\circ}$, a definição de discriminação, observando que esta poderia ocorrer por motivo de raça, cor, sexo, língua, religião, opinião pública ou qualquer outra opinião, origem nacional ou social, condição econômica ou nascimento $^{265}$.

No último quartel do século XX, a temática da educação pela via da especialização, por meio de novas declarações e tratados internacionais voltados para atender às crianças.

A Convenção sobre os Direitos da Criança foi adotada pela Resolução n. 44/25 da Assembléia Geral das Nações Unidas, datada de 20 de novembro de 1989. Após os costumeiros procedimentos de ratificação e depósito de seu instrumento, a Convenção entrou em vigor em 02 de setembro de $1990^{266}$. Este tratado internacional possui grande significância para as relações internacionais do final do século $\mathrm{XX}$, uma vez que sua assinatura ocorreu em meio aos eventos que culminariam com o final da Guerra Fria ${ }^{267}$. A data do evento também é significativa na temática da educação, pois o tratado foi firmado em meio aos festejos dos trinta anos da Declaração sobre os Direitos da Criança de 1959, conforme já analisamos.

Contudo, é importante frisar a diferença entre os dois documentos. Enquanto a Declaração de 1959 possuía caráter recomendatório e não-cogente, a Convenção de 1989 apresenta natureza e formato próprio de tratado internacional, prevendo condutas obrigatórias para os Estados signatários. Nas palavras de José Augusto Lindgren Alves, o avanço obtido por meio deste tratado internacional pode ser sintetizado da seguinte forma:

\footnotetext{
"é o primeiro tratado que consegue regulamentar num único texto juridicamente cogente todos os direitos - civis, políticos, econômicos, sociais e culturais - de uma categoria universal de indivíduos, até então não-encarados propriamente como sujeitos de direitos."268
}

\footnotetext{
${ }^{265}$ Cumpre mencionar que todos os Estados aqui estudados ratificaram este tratado internacional.

266 De acordo com o artigo 49, parágrafo $1^{\circ}$ da Convenção sobre os Direitos da Criança, o tratado internacional entraria em vigor no trigésimo dia após a data da de depósito do vigésimo instrumento de ratificação ou adesão.

${ }^{267}$ O clima de relativo otimismo foi consignado na declaração firmada na Cúpula Mundial da Criança no ano seguinte, a qual afirma em seu artigo $9^{\circ}$ : “Os recentes avanços nas relações políticas internacionais poderão facilitar esta tarefa. A cooperação e a solidariedade internacionais devem possibilitar agora a obtenção de resultados concretos em muitos campos: revitalizar o crescimento e o desenvolvimento econômicos, proteger o meio ambiente, prevenir a disseminação de doenças que causam morte e incapacitação, e alcançar maior justiça social e econômica. (...)".

${ }^{268}$ ALVES, José Augusto Lindgren. Relações Internacionais e Temas Sociais - A Década das Conferências. Brasília: IBRI, 2001. p. 48.
} 
Destarte, diferentemente dos tratados anteriores, não houve uma preocupação específica com a tutela de apenas uma geração específica de direito, conforme atestam os tratados que versam apenas sobre direitos civis e políticos, ou ainda econômicos e sociais. Tratava-se, portanto, do primeiro passo na direção da promoção de uma visão unitária dos direitos humanos, pautada por sua indissociabilidade, a partir do reconhecimento da criança como sujeito de direitos civis, econômicos, sociais e culturais ${ }^{269}$.

Outro ponto do tratado internacional que merece destaque é a previsão da autoinstrumentalização da Convenção, por meio da criação de um órgão próprio de monitoramento, nomeado Comitê para os Direitos da Criança, contando com dezoito especialistas independentes $^{270}$. O Comitê possui atribuições definidas pelo próprio tratado internacional, recebendo informes educacionais qüinqüenais dos Estados-Partes e elaborando relatórios bienais à Assembléia Geral ${ }^{271}$.

A respeito dos direitos educacionais previstos na Convenção sobre os Direitos da Criança, o texto, em seu artigo 28, estabelece os parâmetros da educação enquanto direito das crianças:

"1. Os Estados-Partes reconhecem o direito da criança à educação e, a fim de que ela possa exercer progressivamente e em igualdade de condições esse direito, deverão especialmente:

a) tornar o ensino primário obrigatório e disponível gratuitamente a todos;

\footnotetext{
${ }^{269}$ Conforme já analisamos, esta visão será consagrada no texto da Declaração Universal dos Direitos Humanos, firmada em Viena no ano de 1993. Flávia Piovesan sintetiza o conteúdo dos direitos reconhecidos pelo documento internacional: "A Convenção acolhe a concepção do desenvolvimento integral da criança, reconhecendo-a como verdadeiro sujeito de direito, a exigir proteção especial e absoluta prioridade. Os direitos previstos na Convenção incluem: o direito à vida e à proteção contra a pena capital; o direito a ter uma nacionalidade; a proteção ante a separação dos pais; o direito a deixar qualquer país e de entrar em seu próprio país; o direito de entrar e sair de qualquer Estado-Parte para fins de reunificação familiar; a proteção para não ser levada ilicitamente ao exterior; a proteção de seus interesses no caso de adoção; a liberdade de pensamento, consciência e religião; o direito ao acesso a serviços de saúde, devendo o Estado reduzir a mortalidade infantil e abolir práticas tradicionais prejudiciais à saúde; o direito a um nível adequado de vida e segurança social; o direito à educação, devendo os Estados oferecerem educação primária e gratuita; a proteção contra a exploração econômica, com a fixação de idade mínima para admissão em emprego; a proteção contra o envolvimento na produção, tráfico e uso de drogas psicotrópicas; a proteção contra a exploração e o abuso sexual", Cf. PIOVESAN, Flávia. Direitos Humanos e o Direito Constitucional Internacional. op. cit. pp. 196-197.

${ }^{270}$ Inicialmente estavam previstos apenas 10 especialistas independentes, de forma que o tratado sofreu um procedimento de emenda, a qual foi assinada em 12.11.1995 e entrou em vigor em 18.11.2002. Todos os Estados objetos de estudo neste presente trabalho já ratificaram a mencionada emenda ao artigo 43, parágrafo $2^{\circ}$.

${ }^{271}$ Apesar dos prazos estabelecidos no tratado internacional, ensina-nos Soledad Biedermann a respeito das atividades desenvolvidas no seio deste Comitê: "Sobre La Convención sobre los Derechos del Niño, el informe inicial al Comité de Derechos del Niño se presentó en 1992, el segundo en 1998 (CRC/C/65/Add.12) y el tercero fue examinado en octubre de 2001 (CRC/C/15/Add.166)". Cf. BIEDERMANN, Soledad. op.cit. p. 149. Cumpre salientar que o último relatório enviado à Assembléia Geral data de 16.07.2008.
} 
b) estimular o desenvolvimento do ensino secundário em suas diferentes formas, inclusive o ensino geral e profissionalizante, tornando-o disponível e acessível a todas as crianças, e adotar medidas apropriadas tais como a implantação do ensino gratuito e a concessão de assistência financeira em caso de necessidade;

c) tornar o ensino superior acessível a todos com base na capacidade e por todos os meios adequados;

d) tornar a informação e a orientação educacionais e profissionais disponíveis e acessíveis a todas as crianças;

e) adotar medidas para estimular a freqüência regular às escolas e a redução do índice de evasão escolar (...)"272.

Destacamos dentre os direitos colacionados, a obrigatoriedade e gratuidade do ensino primário (Cine 01), bem como da disponibilidade do ensino secundário a todas as crianças (Cine 02 e 03). Como já nos mostrou o nosso estudo, todos os Estados-membros do MERCOSUL possuem normas internas semelhantes, de forma que a norma internacional apenas reforça a previsão dos ordenamentos nacionais. Não se olvide, contudo, que o Paraguai é o único país da região que não estabeleceu a obrigatoriedade do ensino secundário.

O mesmo artigo supracitado ainda prevê a adoção de medidas necessárias para assegurar que a atividade de ensino não seja atentatória à dignidade humana da criança, além de estabelecer o princípio da cooperação internacional em prol da erradicação do analfabetismo, mormente nos países em desenvolvimento ${ }^{273}$. A Convenção ainda estabelece as linhas gerais da educação a ser ministrada para a criança ${ }^{274}$, definida legalmente como menor de dezoito anos de idade, em seu artigo $1^{\circ}$. Igualmente prevê a liberdade do ensino privado, desde que respeitados os padrões mínimos estabelecidos pelo Estado e os princípios ditados na Convenção ${ }^{275}$.

Com relação à participação dos pais e responsáveis, paralelamente ao reconhecimento da responsabilidade primordial parental, o documento não exime os Estados-Partes da necessidade de envidar os esforços necessários para garantir a assistência adequada aos pais e responsáveis em sua obrigação, colaborando diretamente para a realização eficaz do direito à

\footnotetext{
${ }^{272}$ A tradução para o português deste documento internacional foi retirada da página eletrônica da missão da Organização das Nações Unidas no Brasil, disponível em http://www.onu-brasil.org.br/doc_crianca.php. Acesso em 23 de janeiro de 2010 .

${ }^{273}$ Convenção sobre os Direitos da Criança, art. 28, parágrafos $2^{\circ}$ e $3^{\circ}$.

${ }^{274}$ Convenção sobre os Direitos da Criança, art. 29, parágrafo $1^{\circ}$.

${ }^{275}$ Convenção sobre os Direitos da Criança, art. 29, parágrafo $2^{\circ}$.
} 
educação $^{276}$. O tratado não se omite a respeito das crianças com necessidades especiais, determinando explicitamente a garantia do oferecimento da educação para esse grupo ${ }^{277}$.

Por fim, cumpre mencionar que a Convenção sobre os Direitos da Criança é o tratado internacional de direitos humanos com o maior número de ratificações na história, feito obtido com extrema rapidez. Em apenas dez anos de vigência, faltavam apenas as ratificações de dois países (Somália e Estados Unidos) para se alcançar sua real universalidade ${ }^{278}$. Os Estados-Membros do MERCOSUL também procederam à sua ratificação e depósito com grande rapidez, conforme atesta a tabela abaixo:

\section{Q. 20 - Convenção sobre os Direitos da Criança (ONU, 20.11.1989) ${ }^{279}$}

\begin{tabular}{|c|c|c|c|}
\hline País & Data da Assinatura & Aprovação Legislativa & Data de Ratificação \\
\hline Argentina & 29.06 .1990 & $\begin{array}{c}\text { Norma Constitucional a } \\
\text { partir da Reforma de 1994 }\end{array}$ & 04.12 .1990 \\
\hline Brasil & 26.01 .1990 & $\begin{array}{c}\text { Decreto Legislativo n. 28, } \\
\text { de } 24.09 .90^{280}\end{array}$ & 24.09 .1990 \\
\hline Paraguai & 04.04 .1990 & Ley 57/90, de 20.09.1990 & 25.09 .1990 \\
\hline Uruguai & 26.01 .1990 & Ley 16.137, de 28.09.1990 & 20.11 .1990 \\
\hline
\end{tabular}

${ }^{276}$ Convenção sobre os Direitos da Criança, art. 18.

${ }^{277}$ Convenção sobre os Direitos da Criança, art. 23, parágrafo $3^{\circ}$.

278 ALVES, José Augusto Lindgren. op. cit. p. 56. As ratificações de ambos os países ainda se encontram pendentes, de forma que o tratado internacional conta com 193 Estados partícipes, de acordo com a página eletrônica da ONU, disponível em http://treaties.un.org/Pages/ViewDetails.aspx?src=TREATY\&mtdsg_no=IV$11 \&$ chapter $=4 \&$ lang=en Acesso em 23 de janeiro de 2010.

${ }^{279}$ O tratado também conta com dois protocolos facultativos: Protocolo Facultativo sobre a Participação de Crianças em Conflitos Armados e o Protocolo Facultativo sobre a Venda de Crianças, Prostituição Infantil e Utilização de Crianças na Pornografia, ambos firmados em 25 de maio de 2000.

${ }^{280}$ Pela praxe brasileira, a Convenção foi promulgada pelo Decreto presidencial 99.710/90, de 21.11.1990. 


\section{$\underline{\text { 2.4.3 - A Ousadia das Declarações Mundiais }}$}

Ainda em meio às primeiras ratificações da Convenção sobre os Direitos da Criança, o tema voltou à baila política internacional. Sob os auspícios da ONU, foi realizada a Cúpula Mundial da Criança entre os dias 28 e 30 de setembro de 1990, em Nova Iorque, durante a 45 Sessão Regular da Assembléia Geral da entidade. De acordo com José Augusto Lindgren Alves, a duração relativamente curta do evento mascara o acirrado debate empreendido ao longo das discussões que a antecederam ${ }^{281}$.

Ao final deste encontro, foram firmados dois documentos: (a) Declaração Mundial sobre a Sobrevivência, a Proteção e o Desenvolvimento da Criança e (b) Plano de Ação para a Implementação da Declaração Mundial sobre a Sobrevivência, a Proteção $e \quad o$ Desenvolvimento da Criança. Ambos os documentos reconhecem a necessidade de se tratar da questão infantil a partir de uma perspectiva internacional, onde os Estados se auxiliam na tarefa de promoção dos direitos da criança:

\footnotetext{
"Juntas, nossas nações possuem os meios e os conhecimentos indispensáveis para proteger a vida e minimizar enormemente o sofrimento da criança, para promover o total desenvolvimento do seu potencial humano, e para conscientizá-la de suas necessidades, de seus direitos e de suas oportunidades. A Convenção sobre os Direitos da Criança proporciona nova oportunidade para que o respeito aos direitos e ao bem-estar da criança seja verdadeiramente universal”,282
}

A Declaração ainda faz menção expressa à questão da educação básica, ao reconhecer a existência de 100 milhões de crianças fora das escolas ao redor do mundo, sendo que as meninas compunham dois terços deste total ${ }^{283}$. Em busca da reversão deste quadro, o texto estabelece, em seu artigo 20, um programa de dez pontos principais para a proteção da criança e a melhoria de sua condição de vida. Dentre estes, destacamos a questão da educação:

“(6) Trabalharemos por programas de redução do analfabetismo, e que garantam oportunidades educacionais para todas as crianças, independentemente de sua origem e sexo; que preparem a criança para o trabalho produtivo e para as oportunidades de aprendizagem para toda a vida, isto é, pela educação profissionalizante, e que

\footnotetext{
${ }^{281}$ ALVES, José Augusto Lindgren. op. cit. p. 49.

${ }^{282}$ Declaração Mundial sobre a Sobrevivência, a Proteção e o Desenvolvimento da Criança, artigo $8^{\circ}$. A tradução para o português encontra-se em ALVES, José Augusto Lindgren. op. cit. p. 345-351.

${ }^{283}$ Declaração Mundial sobre a Sobrevivência, a Proteção e o Desenvolvimento da Criança, artigo 13.
} 
permitam que a criança cresça até a idade adulta num contexto cultural e social propício e protetor".

O Plano de Ação, por sua vez, além de repetir os dez pontos mencionados pelo artigo 20 da Declaração, cuida da proposição de metas gerais e setoriais quantificáveis, as quais deveriam ser atingidas até o ano 2000. Neste sentido, remete à Conferência Mundial sobre Educação para Todos, realizada em Jomtien, na Tailândia, onde se decidiu pelo aumento significativo das oportunidades educacionais, com grande ênfase na mulher. Reproduzindo esta preocupação, o Plano de Ação repete a necessidade de se prover o acesso universal à educação primária, com ênfase particular nas meninas e programas intensivos de alfabetização de mulheres.

Em especial, para a educação básica, foram previstas quatro metas ambiciosas, as quais foram elaboradas mediante intenso debate entre governos nacionais e organismos internacionais ${ }^{284}$ :
a) Acesso universal à educação básica e conclusão da educação de primeiro grau de pelo menos $80 \%$ das crianças com idade escolar;
b) Extensão das atividades de desenvolvimento da criança durante a primeira infância, incluindo intervenções apropriadas e de baixo custo baseadas na família e na comunidade.
c) Redução de 50\%, no mínimo, na taxa de analfabetismo entre adultos, com relação a 1990 (o grupo etário apropriado deveria ser definido em cada país), com ênfase na alfabetização das mulheres;

A Declaração e o Plano de Ação ainda instavam aos Estados signatários que procedessem à ratificação e implementação da Convenção sobre os Direitos da Criança, firmada em 1989, o que contribuiu decisivamente para a rápida e ampla aceitação deste tratado internacional ${ }^{285}$.

O estabelecimento de metas prioritárias para a educação básica não consistiu em inovação por parte da Cúpula Mundial da Criança. Na verdade, as três metas repetiam o que se encontrava disposto em Plano de Ação anterior.

Meses antes, em março de 1990, líderes do mundo todo reunidos em Jomtien, na Tailândia, para a Conferência Mundial sobre Educação para Todos haviam elencado uma

\footnotetext{
${ }^{284}$ Plano de Ação para a Implementação da Declaração Mundial sobre a Sobrevivência, a Proteção e o Desenvolvimento da Criança, apêndice.

${ }^{285}$ ALVES, José Augusto Lindgren. op. cit. p. 56.
} 
série de medidas destinadas a assegurar o acesso universal à educação básica, ao longo da década de 90. As metas estabelecidas ficavam a cargo dos Estados signatários, porém, deveriam apresentar consonância com as propostas firmadas na declaração apresentada ao final do encontro. Dentre estas, sublinhamos as seguintes constantes do Plano de Ação, que se encontrava anexo à Declaração ${ }^{286}$ :

8. Cada país poderá estabelecer suas próprias metas para a década de 1990, em consonância às dimensões propostas a seguir:

\section{(...)}

b. Acesso universal e conclusão da educação fundamental (ou qualquer nível mais elevado de educação considerado "básico") até o ano 2000;

c. Melhoria dos resultados de aprendizagem, de modo que a percentagem convencionada de uma amostra de idade determinada (por exemplo, $80 \%$ da faixa etária de 14 anos), alcance ou ultrapasse o padrão desejável de aquisição de conhecimentos previamente definido;

d. Redução da taxa de analfabetismo adulto à metade, digamos, do nível registrado em 1990, já no ano 2000 (a faixa etária adequada deve ser determinada em cada país). Ênfase especial deve ser conferida à alfabetização da mulher, de modo a reduzir significativamente a desigualdade existente entre os índices de alfabetização dos homens e mulheres;

e. Ampliação dos serviços de educação básica e capacitação em outras habilidades essenciais necessárias aos jovens e adultos, avaliando a eficácia dos programas em função de mudanças de comportamento e impactos na saúde, emprego e produtividade;

(...)

g. Sempre que possível, deve-se estabelecer níveis de desempenho para os aspectos anteriormente indicados. Tais níveis devem ser coerentes com a atenção prioritária dada pela educação básica à universalização do acesso e à aquisição da aprendizagem, consideradas aspirações conjuntas e inseparáveis. Em todos os casos, as metas de desempenho devem incluir a igualdade entre os sexos. No entanto, a determinação dos níveis de desempenho e da proporção de participantes que deverão atingir esses níveis em programas específicos de educação básica, deve ser deixada a cargo de cada país

Dez anos após o encontro tailandês, representantes nacionais reuniram-se em Dakar, para reafirmar os pressupostos da Declaração Mundial Sobre Educação para Todos e assegurar os seguintes objetivos, desta vez com vistas ao ano de 2015:

i. expandir e melhorar o cuidado e a educação da criança pequena, especialmente para as crianças mais vulneráveis e em maior desvantagem;

ii. assegurar que todas as crianças, com ênfase especial nas meninas e crianças em

${ }^{286}$ UNESCO. Declaração Mundial sobre a Educação para Todos: Satisfação das Necessidades Básicas de Aprendizagem. Jomtien, 1990, Anexo, artigo $8^{\circ}$. 
circunstâncias difíceis, tenham acesso à educação primária, obrigatória, gratuita e de boa qualidade até o ano 2015;

iii. assegurar que as necessidades de aprendizagem de todos os jovens e adultos sejam atendidas pelo acesso eqüitativo à aprendizagem apropriada, à habilidades para a vida e à programas de formação para a cidadania;

iv. alcançar uma melhoria de 50\% nos níveis de alfabetização de adultos até 2015 , especialmente para as mulheres, e acesso eqüitativo à educação básica e continuada para todos os adultos;

v. eliminar disparidades de gênero na educação primária e secundária até 2005 e alcançar a igualdade de gênero na educação até 2015, com enfoque na garantia ao acesso e o desempenho pleno e eqüitativo de meninas na educação básica de boa qualidade;

vi. melhorar todos os aspectos da qualidade da educação e assegurar excelência para todos, de forma a garantir a todos resultados reconhecidos e mensuráveis, especialmente na alfabetização, matemática e habilidades essenciais à vida.

Corroborando esta preocupação, a temática da educação básica foi inserida num ambicioso plano internacional de promoção de desenvolvimento, apresentado na Conferência Internacional sobre Financiamento para o Desenvolvimento, realizada em 2002 em Monterrey, no México, sob o título de Millennium Development Goals - Objetivos de Desenvolvimento do Milênio, a serem atingidos até o ano de $2015 .{ }^{287}$ Dentre outros objetivos, reafirmaram-se duas metas presentes em Dakar: (a) universalização da "educação primária" (primary schooling), aqui entendida como Cine 01 e 02; e, (b) eliminação da disparidade de gênero na educação primária e secundária (Cine 01 a 03), até 2005, e em todos os níveis educacionais até 2015. O cumprimento destes objetivos tem sido ostensivamente monitorado pela ONU, por meio de informes periódicos. Os resultados estão disponíveis ao público, por meio de página eletrônica especializada. ${ }^{288}$

\section{5 - O Esquema "D+3A" no Plano Internacional}

Valendo-nos da mesma metodologia e critérios aplicados à análise de normas no plano constitucional, passaremos agora a estudar as normas decorrentes dos tratados internacionais incorporados pelos Estados-Membros do MERCOSUL.

\footnotetext{
${ }^{287}$ Mais a respeito das Metas do Milênio em RANIERI, N. B. S. Um Conceito Mais Amplo de Liberdade: Desenvolvimento, Segurança e Direitos Humanos para todos - Multilateralismo e Cidadania Mundial. Política Externa, São Paulo, v. 14, n. 2, 2005, p. 25-39.

${ }^{288}$ Disponível em: http://www.mdgmonitor.org/index.cfm. Acesso em 23 de janeiro de 2010.
} 
A disponibilidade do ensino não é tratada de forma extensa pela normativa internacional. A liberdade de ensino da iniciativa privada é assegurada expressamente pela Convenção sobre os Direitos da Criança (CDC), apenas reforçando disposição presente em todas as constituições estudadas. O PIDESC é o único tratado internacional que prevê o contínuo melhoramento das condições docentes como uma norma a ser observada pelos Estados signatários, tema ausente em todas as Cartas, à exceção da brasileira.

\section{Q.21 - Disponibilidade}

\begin{tabular}{|c|c|}
\hline Em Relação a Escolas & Em Relação a Professores \\
\hline $\begin{array}{l}\text { Educação é um direito de todos } \\
\text { (DADDH, art. 12, 1); (DUDH, art. 26, 1); (PIDESC, art. } \\
\text { 13, 3); (PSS, art. 13,1) }\end{array}$ & \multirow{4}{*}{$\begin{array}{c}\text { Contínuo melhoramento das condições } \\
\text { materiais do pessoal docente (PIDESC, } \\
\text { art. 13,2) }\end{array}$} \\
\hline $\begin{array}{l}\text { Desenvolvimento de uma rede escolar em todos os } \\
\text { escalões de ensino (PIDESC, art. 13,2) }\end{array}$ & \\
\hline $\begin{array}{l}\text { Liberdade de ensino para a iniciativa privada } \\
\text { (CDC, art. 29, 2) }\end{array}$ & \\
\hline $\begin{array}{l}\text { Tratado não pode ser interpretado de forma a restringir a } \\
\text { liberdade das pessoas e entidades de ensino } \\
(\mathrm{PSS}, \text { art. 13, 5) (PIDESC, art. 13, 4) (CDC, art. 29, 2) }\end{array}$ & \\
\hline
\end{tabular}

Quanto à acessibilidade da educação, percebemos uma clara evolução no que tange a obrigatoriedade e gratuidade da educação, de forma a normativa internacional mais recente defende sua extensão aos Cines 01 e 02, período já coberto pelas normas do plano interno dos países mercosulinos. Ressalte-se a importância destes tratados internacionais no ordenamento argentino, visto que sua constituição é silente acerca da obrigatoriedade do ensino. Em função do artigo 75, inciso 24 da CA, a obrigatoriedade presente no PIDESC e no CDC possui hierarquia comparável à norma constitucional. Ainda sobre a acessibilidade, as disposições acerca do ensino não-obrigatório, raras nos ordenamentos constitucionais mercosulinos, estão presentes em diversos tratados internacionais, mitigando eventuais lacunas. 


\section{Q.22 - Acessibilidade}

Ensino Obrigatório

Ensino Não-Obrigatório

Educação é um direito de todos

(DADDH, art. 12, 1); (DUDH, art. 26, 1); (PIDESC, art. 13, 3); (PSS, art. 13, 1)

Responsabilização dos pais pela educação das crianças, com o auxílio do Estado

(CDC, art. 18, 2)

Cine 01 gratuito e dever de conclusão obrigatória deste ciclo (DADDH, art. 12, 1)

Cine 01 e 02 gratuitos e Cine 01 obrigatório (DUDH, art. $26,1)$

Promoção, na medida do possível, dos

Cines 01 e 02 a pessoas que não tiverem recebido ou terminado este ciclo (PSS, art. 13, 3) (PIDESC, art. 13, 2)

Cine 01 e 02 obrigatórios e gratuitos (PIDESC, art. 13, 2); (PSS, art. 13, 3) e (CDC, art. 28, 1)

Cine 03 deve ser acessível a todos e progressivamente oferecido gratuitamente

(PSS, art. 13, 3) (PIDESC, art. 13, 2) (CDC, art. 28, 1)

Elaboração de plano detalhado para a realização do Cine 01 e 02 obrigatório e gratuito (PIDESC, art. 14)

Adoção de medidas para estimular a freqüência regular às escolas e a redução do índice de evasão escolar (CDC, art. $28,1)$

Oferecimento de creches e serviços de assistência social para os pais trabalhadores

(CDC, art. 18, 3)

Tornar a informação e a orientação

Ensino de maneira compatível com a dignidade humana da educacionais e profissionais disponíveis e criança (CDC, art. 28,1$)$ acessíveis a todas as crianças (CDC, art. 28, 1)

Liberdade dos pais na escolha da educação de seus filhos (DUDH, art. 26, 3) (PSS, art. 13, 4) (PIDESC, art. 13, 3)

No campo da admissibilidade, destaca-se a grande previsão de normas constitucionais a esse respeito, sobretudo assegurando auxílio às crianças em necessidade nos países mercosulinos, bem como prevendo disposições especiais a respeito da educação indígena, presente em todas as constituições, salvo a uruguaia, que não realiza essa particularização. Assim, podemos dizer que a extensão normativa constitucional é superior à prevista nos tratados internacionais, apresentando conteúdos detalhados dentro das linhas gerais presentes nestes. 


\section{Q.23 - Admissibilidade}

\section{Regulação e Supervisão}

Oferecimento de um sistema adequado de bolsas

(PIDESC, art. 13, 2)

Vedação a toda e qualquer forma de discriminação na esfera da educação

(CFDR, art. $\left.1^{\circ}, 1\right)$

Liberdade dos pais na escolha da educação de seus filhos

(DUDH, art. 26, 3) (PSS, art. 13, 4) (PIDESC, art. 13, 3)

Criança enquanto sujeito do direito à educação (CDC, art. 28, 1)

Por fim, a adequação, no plano internacional, preocupa-se com o acesso de pessoas portadoras de necessidades especiais e a vedação a toda e qualquer forma de discriminação. As normas constitucionais de fato estabelecem esta igualdade formal no acesso à educação, porém há poucas normas que tratam da igualdade material do acesso, de forma que ganha muita importância o disposto nos tratados internacionais.

\section{Q.24 - Adequação}

\begin{tabular}{|c|c|}
\hline Tratado $^{289}$ & Necessidades Especiais e Educação Não-Escolar \\
\hline PSS & $\begin{array}{l}\text { Estabelecimento de programas de ensino diferenciado para deficientes, a fim de } \\
\text { proporcionar instrução especial e formação a pessoas com impedimentos físicos ou } \\
\text { deficiência mental (PSS, art. 13, 3) }\end{array}$ \\
\hline CDC & Educação para crianças deficientes (art. 23, 3) \\
\hline CDCE & Vedação a toda e qualquer forma de discriminação na esfera da educação (art. $\left.1^{\circ}, 1\right)$ \\
\hline CFDR & Vedação à discriminação racial no âmbito do ensino (art. 5, “e”) \\
\hline CFDM & Vedação à discriminação de gênero no âmbito do ensino (art. 10) \\
\hline CDPD & Oferecimento dos Cines 01 e 02 gratuitos às crianças deficientes (art. 24) \\
\hline
\end{tabular}

\footnotetext{
${ }^{289}$ Para facilitar a leitura desta tabela, apresentamos aqui a legenda empregada nos tratados: Protocolo San Salvador (PSS), Convenção sobre os Direitos da Criança (CDC), Convenção Relativa à Luta Contra a Discriminação no Campo do Ensino (CDCE), Convenção Internacional sobre a Eliminação de Todas as Formas de Discriminação Racial (CFDR), Convenção sobre a Eliminação de Todas as Formas de Discriminação contra Mulher (CFDM) e Convenção sobre os Direitos das Pessoas com Deficiências (CDPD).
} 
Uma vez conhecida a extensão do direito à educação básica nos planos constitucional e internacional, passaremos ao estudo do espaço dedicado à educação no âmbito regional, dentro do contexto de integração desenvolvido no âmbito do MERCOSUL. 


\section{CAPÍTULO 3 - MERCOSUL E O DIREITO À EDUCAÇÃO BÁSICA}

Este último capítulo é dedicado para a proteção normativa no plano regional do MERCOSUL, bem como suas atividades de promoção. Inserido no contexto próprio das regionalizações, buscaremos demonstrar como em tão pouco tempo se estruturou o Setor Educacional do bloco regional, o que gerou enormes expectativas a respeito de uma proteção maior aos direitos educacionais. Contudo, em que pesem os relevantes avanços - aqui relatados - obtidos pelo órgão no sentido de uma maior autonomia, poucos avanços significativos foram colhidos no campo da educação básica, ressalvados os protocolos que garantem a equiparação de diplomas e prosseguimento dos estudos entre os Estados-Partes da experiência integracionista. Percebe-se, outrossim, um destaque demasiado conferido à educação superior.

\section{1 - MERCOSUL dentro da Dinâmica dos Processos de Regionalização}

O século XX coincidiu com um notável aumento das relações políticas, econômicas e sociais entre os diversos Estados. Este aumento está umbilicalmente ligado ao fenômeno crescente da globalização, que ganhou uma força assombrosa ao longo deste século, máxime após os conflitos mundiais que assolaram o globo. Com efeito, a globalização, num sentido estrito, pode ser definida apenas em seus termos econômicos, representando uma crescente intercomunicação dos mercados e a transnacionalização do capital. Todavia, Enrique Lewandowski adverte que:

\footnotetext{
"A globalização, todavia, não se resume a esse novo modo de produção capitalista, organizado em escala mundial. Ela decorre também da universalização dos padrões culturais e da necessidade de equacionamento comum dos problemas que afetam a totalidade do planeta, como a degradação ao meio ambiente, a explosão demográfica, o desrespeito aos direitos humanos, a corrida armamentista etc". ${ }^{290}$
}

\footnotetext{
290 LEWANDOWSKI, Enrique Ricardo. Globalização, Regionalização e Soberania. São Paulo: Juarez Oliveira, 2004. p. 50.
} 
Neste diapasão, o final da Segunda Guerra Mundial produziu uma intensa interdependência econômica e transnacionalização do capital, sobretudo a partir da adoção de um sistema econômico internacional denominado Bretton-Woods. Os avanços na tecnologia das comunicações também se mostraram notáveis. Todavia, o fenômeno trouxe complexos dilemas jurídicos, econômicos, culturais e políticos, na medida em que estas grandes transformações contrastavam com a falta de adaptabilidade dos mecanismos institucionais hodiernos, e consequentemente, sua incapacidade em prover respostas rápidas e eficientes às necessidades dos Estados. A superação destas dificuldades encetou um consenso em torno da necessidade de incentivar a cooperação internacional como forma de atender às novas dificuldades de um mundo globalizado.

Celso Lafer, analisando as perspectivas que se delineiam aos Estados soberanos neste mundo globalizado, antevê um embate entre duas perspectivas no plano internacional: a lógica da fragmentação e a lógica da globalização. Para o autor, o fim das disputas ideológicas que marcaram a segunda metade do século XX antecipou a contraposição destas duas lógicas contraditórias e complementares. ${ }^{291}$ Com efeito, concomitantemente ao processo de intensificação das relações entre os atores do sistema internacional, percebe-se cristalinamente um movimento de recrudescimento do nacionalismo e dos particularismos em face das tentativas de homogeneização política, jurídica, econômica e cultural. ${ }^{292}$

Na visão de Celso Lafer, o crescimento da regionalização pode significar a resposta a essa dicotomia, uma vez que se trata de uma tentativa dos Estados buscarem uma saída coletiva para a obtenção da paz e do desenvolvimento econômico-social em suas respectivas regiões, ao mesmo tempo em que impõem certos limites ao sistema multilateral proposto pela lógica da globalização. Para Enrique Lewandowski, os blocos regionais permitem a coordenação das ações dos Estados-membros “entre si e em face de terceiros, notadamente no campo das trocas internacionais", mesmo que estas associações importem em "consideráveis restrições em sua capacidade de autodeterminação". 293

Leslie Lipson, ao analisar o fenômeno da regionalização, aponta no sentido da gênese e desenvolvimento de uma nova unidade de governo, que segundo o autor, poderia ser

\footnotetext{
${ }^{291}$ LAFER, Celso. O Cenário Mundial e o Relacionamento União Européia/MERCOSUL. Revista de Política Externa, vol. 9., n.1. Ed. Paz e Terra, jun/ago. 2000. p. 89.

${ }^{292}$ LEWANDOWSKI, Enrique Ricardo. op. cit., p. 109.

${ }^{293}$ Idem. op. cit., p. 115-116.
} 
denominada de "Estado-região", em razão da falta de termo mais adequado, visando apenas a sua distinção perante as formas do Estado-mundial ou do Estado-nação. Para o autor,

\begin{abstract}
"torna-se evidente, sem dúvida, que o Estado-nação, unidade de governo que se desenvolveu em virtude de condições especiais verificadas no século XVI e XVII, é inteiramente inadequado para atender às exigências da humanidade, dadas as condições diversas do século XX". ${ }^{294}$
\end{abstract}

$\mathrm{Na}$ visão de Lipson, portanto, a regionalização, na figura de um Estado-região, apresentar-se-ia como uma estrutura mais adequada para responder às necessidades de seus membros e garantir o bem-estar coletivo de suas populações. Neste sentido, os blocos regionais ganham espaço político e jurídico a partir da incapacidade dos Estados em responder às complexidades do mundo globalizado, mormente no campo econômico, social e ambiental, onde a esfera de atuação do Estado se vê cada vez mais restrita diante de amplos desafios que transcendem a esfera nacional. ${ }^{295}$

É inegável, no entanto, que os blocos regionais auxiliam os Estados na consecução de suas finalidades e, também, na promoção e realização dos direitos humanos, como o direito à educação. José Afonso da Silva chega a mencionar o exercício de uma "soberania expandida", a qual se opera somente no plano comunitário. Segundo o autor, ao invés de se operar uma restrição ao seu exercício, representa na verdade a sua expansão, na medida em que o Estado-Membro as políticas públicas estatais ganham em eficácia política e econômica. ${ }^{296}$

Assim, posto que os primeiros objetivos tenham sido eminentemente econômicos, os blocos regionais do fim do século XX se caracterizaram por um aumento significativo no espectro de sua atuação, passado, muitas vezes, a realizar funções eminentemente estatais. ${ }^{297}$

\footnotetext{
${ }^{294}$ LIPSON, Leslie. op. cit. p. 458-459.

${ }^{295}$ A esse propósito, Leslie Lipson afirma que "com o surgir do Estado-região, certas parcelas da humanidade talvez possam erguer suas defesas políticas contra as borrascas econômicas e a aniquilação pelas armas atômicas" cf. Idem. loc. cit.

${ }^{296}$ SILVA, José Afonso da Silva. "Direito regional econômico, Direitos Humanos e Direito Comunitário", In: Piovesan, Flávia (org.) Direitos humanos, globalização econômica e integração regional: desafios do direito constitucional internacional. São Paulo: Max Limonad, 2002. p. 27.

${ }^{297}$ Conforme Marco Tulio Zanzucchi, estas funções correspondem a momentos diversos da atuação estatal. As duas primeiras funções retratam a atividade jurídica stricto sensu do Estado. Em sua função legislativa, o Estado atua na função de positivar as normas jurídicas de conteúdo geral e abstrato, enquanto a função jurisdicional pressupõe a aplicação do Direito ao caso concreto, de forma que a norma geral e abstrata transmuta-se em comando concreto e singular, a partir da identificação do critério de justiça. Entretanto, a função executiva do poder do Estado diz respeito ao governo pela administração. Nesta atividade, a atuação do Estado não se assemelha à abstratalidade da função legislativa, nem à irrevocabilidade da função jurisdicional e executiva, v. ZAN-
} 
Isto ocorre em virtude de um "deslocamento da capacidade de formulação, de definição e de execução de políticas públicas, antes radicada no Estado, para arenas transnacionais ou supranacionais, decorrentes da globalização econômica e de seus efeitos". ${ }^{298}$

É neste contexto em que se insere o surgimento do Mercado Comum do Sul MERCOSUL, experiência de regionalização do Cone Sul. Trata-se do resultado de um processo acelerado de integração econômica, que conheceu rápida estruturação de um complexo arcabouço institucional, com significativos resultados no campo comercial e econômico, malgrado as vicissitudes econômicas que assolaram os Estados do subcontinente nestes últimos vinte anos. A exemplo do que ocorreu na experiência européia, a aproximação econômica dos Estados-Partes do MERCOSUL encetou uma reinterpretação qualitativa da proposta de integração, inspirada pela preocupação comunitária em melhorar as condições de vida dos cidadãos pertencentes aos países do bloco.

\section{$\underline{\text { 3.1.1 - Breve Histórico da Integração Sub-Regional }}{ }^{299}$}

As primeiras concepções de integração regional latino-americana surgiram no cenário do pós-guerra, arrimadas na defesa de uma maior cooperação econômica entre os países do subcontinente, com vistas à aceleração do ainda incipiente processo de industrialização regional. Sob os auspícios da Comissão Econômica para a América Latina (CEPAL), criada em 1948, e o amadurecimento do processo europeu de integração econômica ${ }^{300}$, buscou-se o desenvolvimento de uma união aduaneira regional, idéia que ganhou concretude com o

ZUCCHI, Marco Tullio. Instituzioni di Diritto Pubblico secondo la Nuova Constituzione. $8^{\mathrm{a}}$ ed. rev. Milano: Dott. A. Giuffrè, 1948. p. 24-26.

${ }^{298}$ FREITAS JUNIOR, Antônio R. Os Direitos Sociais como Direitos Humanos num Cenário de Globalização Econômica e de Integração Regional. In: PIOVESAN, Flávia (coord.). Direitos Humanos, Globalização Econômica e Integração Regional - Desafios de Direito Constitucional Internacional. São Paulo: Max Limonad, 2002. p.105.

${ }^{299}$ Para um estudo mais aprofundado do tema, sugere-se a leitura de CASELLA, Paulo Borba. "Os Processos Latino-Americanos de Integração". In: CASELLA, Paulo Borba (coord.). MERCOSUL - Integração Regional e Globalização. Rio de Janeiro: Renovar, 2000. p. 305-321.

${ }^{300}$ Insta salientar que poucos anos antes, precisamente em 1957, os europeus haviam dado audacioso salto em direção à integração econômica, por meio da assinatura do Tratado de Roma, responsável pela criação do Mercado Comum Europeu. 
advento da Associação Latino-Americana de Livre-Comércio (ALALC), a partir da aprovação do Tratado de Montevidéu, datado de $1960 .^{301}$

Em que pese a ousadia desta iniciativa, as diferenças significantes de nível de desenvolvimento socioeconômico entre os participantes, além da excessiva timidez das medidas empregadas pela recém-criada comunidade desestimularam uma maior integração econômica de seus membros, restringindo sua atuação apenas nos casos de "liberalização comercial, reciprocidade na outorga de concessões e tratamento da cláusula da nação mais favorecida, a partir da consolidação da zona de livre comércio com a proposta de um período de transição de doze anos". ${ }^{302}$

Frustrado este primeiro esforço de aproximação, um novo Tratado de Montevidéu ensejou a criação da Associação Latino Americana de Integração - ALADI, em 12 de agosto de $1980 .{ }^{303}$ Com vistas a dar prosseguimento ao processo de integração já encetado, buscavase o estabelecimento de um mercado comum latino-americano, mediante a adoção gradual de medidas que permitissem o aprofundamento harmônico desta concertação econômica. ${ }^{304}$

Ademais, o tratado fundador da ALADI permitia e estimulava a celebração de acordos parciais entre os seus membros, pois, diz seu artigo $7^{\circ}$ que estes acordos "propendem a criar condições necessárias para o aprofundamento do processo de integração regional mediante sua progressiva multilateralização”.

Contudo, diante de um cenário econômico internacional desfavorável, poucos foram os avanços auferidos por esta nova associação no âmbito regional. Salienta-se, outrossim, a excessiva deficiência em estruturação destas associações, vez que não dispunham de tribunal

\footnotetext{
301 Os países originalmente signatários do Tratado de Montevidéu eram: Argentina, Brasil, Chile, México, Paraguai, Peru e Uruguai. A este rol, aderiram Colômbia e Equador já em 1961, enquanto as adesões de Bolívia e Venezuela se deram apenas em 1967.

302 RIBEIRO, Patrícia Henriques. As Relações entre o Direito Internacional e o Direito Interno - Conflito entre o Ordenamento Brasileiro e Normas do MERCOSUL. Belo Horizonte: Del Rey, 2001. p. 162. Afirma ainda a autora que a atuação da ALALC almejava apenas o cumprimento das normas do GATT - Acordo geral de Tarifas e Comércio.

303 Os países signatários da ALADI, pactuada em meio à reunião do Conselho de Ministros das Relações Exteriores da ALALC, foram: Argentina, Bolívia, Brasil, Chile, Colômbia, Equador, México, Paraguai, Peru, Uruguai e Venezuela.

304 "São funções básicas da Associação: a promoção e regulação do comércio entre as Partes Contratantes, a complementação econômica e o desenvolvimento de ações de cooperação econômica que coadjuvem na ampliação dos mercados", Cf. CASELLA, Paulo Borba. op. cit. p. 309.
} 
supranacional e instrumentos comunitários que garantissem a aplicação do direito regional ${ }^{305}$, aquém, portanto, da experiência integracionista empenhada pelo Pacto Andino. ${ }^{306}$

Ante ao exposto e a despeito dos fracassos anteriores, a partir de meados da década de 80, a aproximação gradual de Brasil e Argentina injetou novo ânimo para uma tentativa ambiciosa de criação de um mercado comum sul-americano. Convém mencionar que esta somente foi possível, em virtude do fim dos regimes militares no Cone Sul, ${ }^{307}$ conforme apontam os diplomatas brasileiros Sérgio Florêncio e Ernesto Araújo:

"O MERCOSUL não seria possível com a sobrevivência de regimes militares na
região. Estes tendem a reger-se pela lógica da confrontação, onde o ganho de um
país é sempre visto com suspicácia, pois é associado imediatamente a uma perda
no outro país. Esta lógica corresponde, na teoria das Relações Internacionais, ao
chamado Jogo de Soma Zero (o que um parceiro ganha é sempre igual ao que outro
perde). Esse jogo é incompatível com a integração, que se rege pela lógica da
cooperação política e da crescente interdependência econômica entre os
parceiros".

O primeiro passo no sentido da aproximação foi dado por meio da Declaração do Iguaçu, em novembro de 1985, onde os presidentes José Sarney e Raúl Alfonsín formalizaram o desejo de integração, estendendo-o a outros países da América do Sul. ${ }^{309}$ A

\footnotetext{
${ }^{305}$ CASELLA, Paulo Borba. MERCOSUL - exigências e perspectivas. São Paulo:LTr, 1996. p. 133-134.

${ }^{306}$ Descontentes com os resultados alcançados pela ALADI, governos do Chile, Colômbia, Equador e Peru firmam a Declaração de Bogotá, em 1966, pavimentando o caminho para a criação do Pacto Andino, que contaria ainda com adesões de Bolívia e Venezuela, além da retirada chilena, em 1976, durante o governo Pinochet. Trata-se, na verdade, da experiência integracionista latino-americana mais avançada, contando com Parlamento e Tribunal comunitário, responsável por declarar as normas comunitárias e solucionar seus eventuais conflitos. Entretanto, após início bastante promissor, amarga hoje atuação excessivamente discreta, $C f$. Idem. op. cit. p. 137-139. Após 1996, denomina-se o bloco regional andino de Comunidade Andina das Nações.

307 Aponta Fátima Anastasia que o período de ruptura autoritária argentina perdurou entre 1976-1983, enquanto a brasileira ocorreu entre os anos de 1964 e 1984. Esclarece, ainda, que a Argentina, diferentemente do Brasil, conheceu período de transição democrática longo, entre os anos de 1984 e 1993, encerrado com a ampla Reforma Constitucional empreendida em 1994. O Brasil, por sua vez, teve curto período de transição democrática, entre os anos de 1985 e 1987. Mais a respeito, ver: ANASTASIA, Fatima et alli. "Redemocratização, Integração Regional e a Trajetória do Setor Educacional MERCOSUL". In: MERCOSUL. Estudo Analítico-Comparativo do MERCOSUL (2001-2005). Brasília: Inep, 2008. p. 41.

${ }^{308}$ FLORENCIO, Sérgio A. L.; ARAÚJO, Ernesto H. F. MERCOSUL Hoje. São Paulo: Alfa Omega, 1995. p. 42. Também a favor desta posição podemos mencionar: CHIARELLI, Carlos Alberto. "Educação: Início e Fim da Integração". In: CHIARELLI, Carlos A.; SIENRA, Jorge. A Educação em um Processo de Integração. São Paulo: LTr, 2001. p. 17.

309 "En ese marco, Argentina y Brasil señalaron que el proceso de integración se basaría en: promover las condiciones para la creación gradual de un mercado común entre ambos países al cual podrían asociarse otros países de América del Sur; aumentar el poder político y la capacidad de negociación de ambos países a través de la institucionalización del sistema de consultas bilaterales; alcanzar el máximo de autosuficiencia posible en materias primas esenciales, insumos y bienes de capital sustituyendo el dólar como moneda de intercambio; intensificar la cooperación científico tecnológica en sectores de punta, biotecnología, energía nuclear, informática etc.", $C f$. ALFONSÍN, Raul. "El Acta de Iguazu". In: COMISSÃO PARLAMENTAR CONJUNTA DO MERCOSUL. Um País Chamado MERCOSUL. Brasília: Senado Federal, 2001. p. 32.
} 
esta declaração, seguiram-se as assinaturas da "Ata de Integração Brasil-Argentina" (1986) e do "Tratado de Integração, Cooperação e Desenvolvimento" (1988), sendo que este delineava um processo de integração bilateral, com vistas à criação de um mercado comum num prazo de dez anos. ${ }^{310}$ Estes esforços incentivaram a celebração de vinte e quatro Protocolos em diversos setores econômicos e políticos, posteriormente consolidados no Acordo de Complementação Econômica n.14, o qual entrou em vigor no dia 01.01.1991. ${ }^{311}$

Os rápidos avanços institucionais obtidos por Brasil e Argentina, bem como os satisfatórios resultados econômicos auferidos em razão destes, despertou o interesse de países vizinhos, notadamente Paraguai e Uruguai, os quais, a partir de agosto de 1990, tornaram-se parte do processo de integração, com vistas à criação de um bloco regional no Cone Sul. Estavam assim semeadas as bases de um projeto maior de integração, mediante a constituição institucional de um mercado comum. Celebrou-se, pois, em 26.03.1991, o Tratado de Assunção, responsável por sedimentar os propósitos, princípios e estrutura orgânica do MERCOSUL - Mercado Comum do Sul.

À guisa de conclusão, pode-se afirmar que

\begin{abstract}
“esse caminho percorrido desde 1960 nos permite perceber que o MERCOSUL está apoiado sobre uma base tríplice: jurídica, política e econômica. A base jurídica é representada pela ALADI: o MERCOSUL está vinculado à ALADI na forma de uma Acordo de Complementação Econômica entre Brasil, Argentina, Paraguai e Uruguai, e obedece a todos os princípios e normas daquela Associação. A base política consiste no processo de redemocratização, vivido pelos quatro países na década de 80, e no empenho de seus mais altos mandatários, ao longo dos anos, em criar e estimular um processo de integração. E a base econômica é configurada pela crescente diversidade e capacidade produtiva das quatro economias. ${ }^{312}$
\end{abstract}

\title{
3.1.2 A Consolidação Institucional do MERCOSUL
}

\footnotetext{
${ }^{310}$ Este prazo, contudo, foi redimensionado para 31.12.1994, consoante o previsto na "Ata de Buenos Aires", firmada pelos presidentes Fernando Collor e Carlos Menem, em julho de 1990.

${ }^{311}$ Ensina-nos André de Carvalho Ramos que "o ACE n. 14 foi precursor de órgãos depois aproveitados pelo MERCOSUL, como o Grupo Mercado Comum e os Subgrupos especializados”, $C f$. RAMOS, André de Carvalho. Direitos Humanos na Integração Econômica - análise comparativa da proteção de direitos humanos e conflitos jurisdicionais na União Européia e MERCOSUL. Tese (Livre-Docência) - Faculdade de Direito, Universidade de São Paulo, São Paulo, 2005. p. 178.

${ }^{312}$ FLORENCIO, Sérgio A.L.; ARAÚJO, Ernesto H.F. op. cit. p. 41.
} 
Ensina-nos Enrique Lewandowski que o MERCOSUL vinha a lume com o propósito precípuo de "atingir o desenvolvimento econômico, dentro dos marcos da justiça social", 313 constituindo-se, assim, em "associação qualitativamente superior a uma zona de livre comércio ou a uma união aduaneira", ${ }^{314}$ de modo que as diretrizes esposadas pelo Tratado de Assunção (TA) em seu artigo $1^{\circ}$ correspondiam à pretensão de implementação gradual de um mercado comum intrabloco, prevista para terminar em 31.12.1994, mesma data já prevista pela Ata de Buenos Aires, firmada entre os Estados do Brasil e Argentina. ${ }^{315}$

A fim de se atingir os objetivos colimados, foram criados neste tratado fundante dois órgãos diretivos para a condução do bloco regional: Conselho do Mercado Comum (CMC) e Grupo Mercado Comum (GMC). ${ }^{316}$ No entanto, o tratado institutivo também prevê a criação de uma Secretaria Executiva do $\mathrm{GMC}^{317}$, Subgrupos de Trabalho do $\mathrm{GMC}^{318}$ e Comissão Parlamentar Conjunta (CPC $)^{319}$. Todos estes serão analisados de forma mais detida adiante.

Cumpre salientar que, neste primeiro momento do MERCOSUL, as instituições político-jurídicas apresentam forte caráter intergovernamental, de modo que as decisões somente poderiam ser tomadas por consenso e na presença de todos os seus representantes. Aos olhos de Sergio Abreu, ministro uruguaio de Relações Exteriores entre 1993 e 1995, a

\footnotetext{
${ }^{313}$ LEWANDOWSKI, Enrique Ricardo. op. cit. p. 134.

${ }^{314}$ Idem. loc. cit. Segundo o autor, podemos identificar cinco tipos de blocos comerciais de caráter regional: "(1) o acordo de comércio preferencial, em que os integrantes estabelecem alguns privilégios tarifários, facilitando o acesso aos mercados uns dos outros; (2) a zona de livre comércio, na qual as tarifas entre os membros são eliminadas, embora mantidas as originalmente estabelecidas com relação a terceiros; (3) a união aduaneira, em que os membros liberalizam o comércio entre si, erigindo uma tarifa uniforme com relação a terceiros; (4) o mercado comum, que corresponde à retirada de todas as restrições à movimentação interna dos fatores de produção; e (5) a união econômica, em que há uma unificação das políticas, fiscal, monetária e social”, Cf. Idem. op. cit. p. 117.

315 Dentre os objetivos do bloco, sedimentados no mencionado artigo primeiro do Tratado de Assunção, encontramos: "Art. $1^{\circ}$. - (...) Este Mercado Comum implica: livre circulação de bens, serviços e fatores produtivos entre os países, através, entre outros, da eliminação dos direitos alfandegários e restrições nãotarifárias à circulação de mercadorias ou qualquer outra medida equivalente; o estabelecimento de uma tarifa externa comum e a adoção de uma política comercial uniforme com relação a terceiros Estados ou agrupamentos de Estados e a coordenação de posições em foros econômico-comerciais regionais e internacionais; a coordenação de políticas macroeconômicas e setoriais entre os Estados-partes - de comércio exterior, agrícola, industrial, fiscal, monetária, cambial e de capitais, de serviços, alfandegária, de transportes e comunicações e outras que se acordem -, a fim de assegurar condições adequadas de concorrência entre os Estados-partes; e, o compromisso dos Estados-partes de harmonizar suas legislações nas áreas pertinentes, para lograr o fortalecimento do processo de integração".

${ }^{316}$ Conforme artigo $9^{\circ}$. do TA.

${ }^{317}$ Art. 15 do TA.

${ }^{318}$ Art. 13 do TA.

${ }^{319}$ Art. 24 do TA.
} 
"prudência", pela qual se caracterizou a primeira estrutura institucional e política do MERCOSUL, foi responsável direta pelo sucesso comercial intrabloco, apontando que

"una institucionalidad técnica y jurídicamente ambiciosa podría haber
comprometido, durante el inicio del proceso, la marcha de um proyecto que debía
perfeccionarse, paso a paso, em función del cumplimiento del programa de
liberación comercial, tendiente a la configuración de la zona de libre comercio".

O recém-nascido MERCOSUL apresentava-se distante, portanto, das aspirações coetâneas européias, que já em 1992, por meio da assinatura do Tratado de Maastricht, estabeleceram, além de uma união econômica e monetária integral, também a preocupação com a constituição de um corpo social comum, consubstanciado na tutela de direitos socioeconômicos comuns, revestida por uma nova cidadania concedida pelo bloco: a cidadania européia. ${ }^{321}$

Diante, contudo, da impossibilidade do cumprimento do prazo previsto no artigo $1^{\mathrm{o}}$. do TA, representantes dos países-membros assinaram, em 17 de dezembro de 1994, o Protocolo de Ouro Preto (POP), que tinha por objetivo principal regulamentar a etapa intermediária de união aduaneira, antes de se atingir o esperado mercado comum. Segundo Lewandowski, esta etapa consistiu-se em uma união aduaneira imperfeita, "na medida em que a tarifa externa comum deixou de abarcar algumas mercadorias, tais como os bens de capital e os equipamentos de informática e telecomunicações". ${ }^{322}$ Os grandes avanços conquistados em Ouro Preto referem-se ao desenho institucional definitivo, bem como a dotação de personalidade jurídica de Direito Internacional ao organismo internacional. ${ }^{323}$

A agenda inicial do MERCOSUL, voltada a princípio para o crescimento e aprofundamento das relações comerciais entre seus membros, sofreu profundas alterações logo em seus primeiros anos, ampliando-se gradativamente de forma a abarcar uma aproximação regional que contemplasse outras esferas do desenvolvimento social. Imbuídos

\footnotetext{
${ }^{320}$ ABREU, Sergio. "El Mercosur a diez años de su creación" In: COMISSÃO PARLAMENTAR CONJUNTA DO MERCOSUL. Um País Chamado MERCOSUL. Brasília: Senado Federal, 2001. p. 53.

${ }^{321}$ CARTOU, Louis. L'Union Européene - Traités de Paris, Rome, Maastricht. $2^{\mathrm{a}}$ ed. Paris: Dalloz, 1996. p. 63. O artigo $8^{\circ}$ do Tratado da União Européia possui a seguinte redação: "é cidadão da União Européia toda pessoa que tenha a nacionalidade de um Estado-membro".

${ }^{322}$ LEWANDOWSKI, Enrique R. op. cit. p. 136.

${ }^{323}$ RAMOS, André de Carvalho. op. cit. p. 184. A permissão da aquisição de direitos e obrigações de forma distinta dos seus países-membros representou um fortalecimento do MERCOSUL, que poderia agir de forma indistinta aos Estados participantes. Contudo, esta liberdade é mitigada pelo ainda presente forte apelo intergovernamental do bloco, evidenciada pelas decisões necessariamente consensuais.
} 
deste espírito, os primeiros anos do bloco foram pródigos no número de protocolos assinados no âmbito do bloco, nas mais diversas áreas. ${ }^{324}$ É neste contexto que se insere a estruturação do Setor Educacional do MERCOSUL, conforme veremos adiante.

Também foram rápidas as primeiras associações de outros Estados ao MERCOSUL. A participação destes Estados já encontrava amparo na Decisão CMC 14/96, que regulamentava a presença de países associados nas reuniões do bloco. Por meio da celebração de Acordos de Complementação Econômica entre o MERCOSUL e os Estados do Chile ${ }^{325}$ e Bolívia ${ }^{326}$ portanto no âmbito da ALADI, buscava-se consolidar zonas de livres comércios entre estes países e o bloco regional.

As graves fragilidades econômicas, bem como as diferenças estruturais dos projetos integracionistas dos países-membros, colocaram o MERCOSUL em xeque ao final da década de 90. Diante das vicissitudes econômicas, os Estados partícipes tiveram nova dificuldade em articular e harmonizar políticas econômicas e comerciais, como pretendiam os tratados basilares do bloco. Destarte, pouco se avançou em relação ao aperfeiçoamento da união aduaneira imperfeita existente, vez que a adoção de políticas cambiais destoantes acabou por favorecer decisivamente as exportações brasileiras após a desvalorização do real em janeiro de 1999, motivando o governo argentino a adotar duras medidas para contê-las.

Diante do clima de incerteza que pairava sobre o futuro do MERCOSUL, corajosamente os Estados partícipes decidiram-se, em 2000, pelo relançamento do projeto,

\footnotetext{
${ }^{324}$ Para mencionar alguns dos mais relevantes: Protocolo de Las Leñas de Cooperação e Assistência Jurisdicional em Matéria Civil, Comercial, Trabalhista e Administrativa (Decisão CMC 05/92); Protocolo de Buenos Aires sobre Jurisdição Internacional em Matéria Contratual (Decisão CMC 01/94); Protocolo sobre Medidas Cautelares (Decisão CMC 27/94); Protocolo de Assistência Jurídica Mútua em Assuntos Penais (Decisão CMC 02/96); Protocolo Santa Maria sobre Jurisdição Internacional em Matérias de Relação de Consumo (Decisão CMC 10/96); Protocolo de Integração Cultural do MERCOSUL (Decisão CMC 11/96); e Protocolo de Defesa da Concorrência do MERCOSUL (Decisão CMC 18/96).

${ }^{325}$ O Acordo de Complementação Econômica n.35 é datado de 25 de junho de 1996. A participação do Chile nos órgãos do MERCOSUL foi definida pela Decisão CMC 12/97. Cumpre salientar que, de acordo com Isidro Montecino, "desde sus comenzios (Mercosur), Chile fue invitado a ser parte de esse tratado, pero circunstancias históricas, y por las políticas económicas impalntadas em esse momento, como alicuotas de importación, lo distaciaban del resto de los países que configuraban el Mercosur", $C f$. MONTECINO, Isidro C. C. "Acuerdo de Complementación Chile \& Mercosur". In: CASELLA, Paulo B. (coord.). MERCOSUL - Integração Regional e Globalização. Rio de Janeiro: Renovar, 2000. p. 219.

326 O Acordo de Complementação Econômica n.36 é datado de 17 de dezembro de 1996. A participação da Bolívia nos órgãos do MERCOSUL foi definida pela Decisão CMC 38/03. Em dezembro de 2006, a Bolívia manifestou predisposição de iniciar os trabalhos da incorporação por carta enviada à Presidência Pro Tempore do bloco. Em seguida, a Decisão CMC 01/07 criou Grupo de Trabalho ad hoc para a definição dos termos da incorporação.
} 
buscando, sobretudo, a consolidação do objetivo traçado pelo POP, qual seja, a construção de uma união aduaneira efetiva, ainda não alcançada. Para André de Carvalho Ramos,

\begin{abstract}
"os temas escolhidos para tal relançamento foram oportunos: acesso ao mercado, agilização dos trâmites de fronteira, incentivos aos investimentos, tarifa externa comum, defesa comercial e livre-concorrência, solução de controvérsias, incorporação da normatividade derivada e relações externas, em especial a formação de uma zona de livre-comércio das Américas", 327
\end{abstract}

Os esforços envidados não foram em vão. Posto que a crise econômica argentina tenha se agravado nos primeiros anos desta década, foi possível a celebração de outro marco no processo de integração do Cone Sul - o Protocolo de Olivos, assinado 18.02.2002 e em vigor a partir de 2004, cujo objetivo foi a revogação expressa do procedimento de solução de controvérsia previsto pelo Protocolo de Brasília, adotando-se critérios de maior agilidade na composição de conflitos. ${ }^{328}$

A despeito dos efeitos da crise econômica que ainda afeta a região, contata-se, nos últimos anos, uma forte retomada do comércio intrabloco. ${ }^{329}$ Desta forma, o MERCOSUL volta a ser atrativo a outros países da região, conforme podemos notar pelo aumento significativo do número de Estados associados ao bloco regional nos últimos anos, todas de países andinos. Neste diapasão, enumeramos as associações dos Estados do Peru ${ }^{330}$, Equador $^{331}$ e Colômbia ${ }^{332}$.

Diferentemente do status de associado gozado por estes países, o governo da Venezuela pleiteou sua adesão como membro efetivo do MERCOSUL ${ }^{333}$, a qual foi formalizada por meio do Protocolo de Adesão assinado pelos presidentes dos Estadosmembros do bloco e o presidente venezuelano em 04 de julho de 2006. Atualmente, a

\footnotetext{
${ }^{327}$ RAMOS, André de Carvalho. op. cit. p. 187-8.

${ }^{328}$ Cf. artigo 55 do Protocolo de Olivos: "O presente protocolo derroga, a partir de sua entrada em vigência, o Protocolo de Brasília para a Solução de Controvérsias, adotado em 17 de dezembro de 1991 e o Regulamento do Protocolo de Brasília, aprovado pela Decisão CMC 17/98”.

${ }^{329}$ O Ministério das Relações Exteriores do Brasil aponta que, entre 2002 e 2007, a corrente de comércio entre o Brasil e os países do MERCOSUL saltou de U\$ 8,9 bilhões para US\$ 28,9 bilhões. Dados disponíveis em: http://www.MERCOSUL.gov.br/principais-tema-da-agenda-do-MERCOSUL/dados-basicos-e-principaisindicadores-economicos-comerciais/evolucao-recente-do-comercio-intrazonal. Acesso em 30 de janeiro de 2010.

${ }^{330}$ Consultar Decisão CMC 39/03, datada de 15.12.2003.

${ }^{331}$ Consultar Decisão CMC 43/04, datada de 16.12.2004.

${ }^{332}$ Consultar Decisão CMC 44/04, datada de 16.12.2004.

333 Processo iniciado com a Decisão CMC 29/05, datada de 08.12.2005. Cumpre lembrar que a Venezuela já havia se associado ao MERCOSUL pela Decisão CMC 42/04.
} 
aprovação do ingresso depende somente do congresso paraguaio, após a ratificação dos outros parlamentos nacionais ${ }^{334}$.

Ressalta-se que a participação de Estados Associados, contudo, foi revista pela Decisão CMC 18/04, a qual estabeleceu como condição de admissibilidade a adesão obrigatória ao "Protocolo de Ushuaia sobre Compromisso Democrático no MERCOSUL, República da Bolívia e República do Chile" e à "Declaração Presidencial sobre Compromisso Democrático no MERCOSUL". Reforça-se, assim, o reconhecimento da importância da democracia para o futuro do bloco, bem como para um desenvolvimento socioeconômico calcado na justiça social. Estranhamente, entretanto, a norma mercosulina que versa sobre a adesão efetiva de Estados ao MERCOSUL é silente a respeito da adesão às declarações em favor da democracia. ${ }^{335}$

\section{2 - As Instituições do MERCOSUL}

O sistema institucional do MERCOSUL, conforme já mencionado, ganhou seu desenho definitivo após a aprovação do Protocolo de Ouro Preto (POP), que estabeleceu em seu artigo $1^{\circ}$ a estrutura institucional definitiva do MERCOSUL, contando com os seguintes órgãos: Conselho do Mercado Comum (CMC); Grupo Mercado Comum (GMC); Secretaria Administrativa do MERCOSUL (SAM); Comissão Parlamentar Conjunta (CPC); Comissão de Comércio do MERCOSUL (CCM); e, Foro Consultivo Econômico-Social (FCES). Em razão da natureza do presente estudo, trataremos apenas do $\mathrm{CMC}$, dentro do qual se insere o Setor Educacional do MERCOSUL.

\footnotetext{
${ }^{334}$ Frise-se que o Protocolo de Adesão somente terá validade a partir de 30 dias após do depósito da ratificação paraguaia, a qual, até o presente momento, não foi submetida à votação, devido à intensa oposição ao ingresso venezuelano. A ratificação argentina veio por meio da aprovação da Lei 26.192, promulgada em 07.12.2006 e submetida ao competente depósito em 14.02.2007. A ratificação uruguaia ocorreu pela Lei 18.053, promulgada em 06.11.2006 e submetida ao competente depósito em 30.08.2007. A ratificação venezuelana ocorreu no dia 13.07.2006. A apreciação brasileira da adesão venezuelana conheceu longo caminho, marcado sempre por votações polêmicas: a Câmara dos Deputados registrou 265 votos favoráveis, 61 contrários e 6 abstenções, enquanto o Senado brasileiro manifestou-se favoravelmente, em 15.12.2009, em votação apertada: 35 votos a favor e 27 contrários. Contudo, Brasil e Venezuela não procederam ao depósito do instrumento de ratificação até a presente data.

335 Consultar a Decisão CMC 28/05, a qual regulamenta o art. 20 do POP, que versa sobre a incorporação de Estados ao bloco regional. Não obstante, a Venezuela ratificou formalmente o Protocolo de Ushuaia em 15.02.2007.
} 


\subsubsection{Conselho Mercado Comum}

Definido no artigo $3^{\circ}$. do Protocolo de Ouro Preto, o Conselho do Mercado Comum (CMC) é o órgão superior do MERCOSUL, dotado de natureza intergovernamental e capacidade decisória. Possui o objetivo precípuo de condução política do processo de integração, visando a assegurar o cumprimento dos objetivos estabelecidos no Tratado de Assunção, por meio da formulação de políticas e promoção de ações necessárias à conformação do mercado comum.

Para a consecução desta finalidade, é composto pelos Ministros de Relações Exteriores e Ministros de Economia dos Estados-Partes, ou ainda seus equivalentes. A importância do órgão é explicitada pela previsão de realização de uma reunião semestral com a presença dos presidentes dos Estados-Partes, sendo que costumeiramente os encontros são coordenados pelos ministros das Relações Exteriores. ${ }^{336}$

Símbolo do intergovernamentalismo regional, a presidência do órgão é exercida pelo país que ocupe a Presidência Pro Tempore do bloco regional. Esta é rotativa entre os Estados pelo período de seis meses, seguindo a ordem alfabética, a exemplo do que ocorria na União Européia antes da aprovação de seu tratado constitutivo. ${ }^{337}$

As funções e atribuições do CMC são bastante amplas, elencadas no artigo $8^{\circ}$. do $\mathrm{POP}^{338}$, sendo que podemos ressaltar o exercício da titularidade da personalidade jurídica do

\footnotetext{
${ }^{336}$ Arts. $4^{\circ}$ a $7^{\circ}$ do POP. Cumpre realçar que poderão participar das reuniões outros convidados ministeriais ou autoridades de nível ministerial, o que mitiga o caráter excessivamente econômico do órgão de cúpula do bloco, visto que apenas os Ministros de Relações Exteriores e Economia possuem lugar cativo nas reunióes do CMC. ${ }^{337}$ Art. $5^{\circ}$ do POP.

338 Art. $8^{\circ}$. do POP: "São funções e atribuições do Conselho do Mercado Comum: (a) velar pelo cumprimento do Tratado de Assunção, de seus protocolos e dos acordos firmados em seu âmbito; (b) formular políticas e promover as ações necessárias à conformação do mercado comum; (c) exercer a titularidade da personalidade jurídica do MERCOSUL; (d) negociar e firmar acordos em nome do MERCOSUL com terceiros países, grupos de países e organizações internacionais, podendo estas funções ser delegadas ao Grupo Mercado Comum por mandato expresso, nas condições estipuladas no inciso VII do artigo 14; (e) manifestar-se sobre as propostas que lhe sejam elevadas pelo Grupo Mercado Comum; (f) Criar reuniões de ministros e pronunciar-se sobre os acordos que lhe sejam remetidos pelas mesmas; (g) criar os órgãos que estime pertinentes, assim como modificá-los ou extingui-los; (h) esclarecer, quando estime necessário, o conteúdo e o alcance de suas decisões; (i) designar o Diretor da Secretaria Administrativa do MERCOSUL; (j) adotar decisões em matéria financeira e orçamentária; e, (k) homologar o Regimento Interno do Grupo Mercado Comum”.
} 
MERCOSUL, o que lhe confere poderes para negociar e firmar acordos em nome do MERCOSUL perante terceiros. O Protocolo também inova ao prever que esta função poderá ser delegada ao Grupo Mercado Comum, segundo condições estipuladas no próprio instrumento legal.

Ao CMC também compete a adoção de decisões em matéria financeira e orçamentária, as quais, obtidas pelo consenso, serão obrigatórias para os Estados-Partes. Outrossim, deve o CMC se pronunciar sobre as propostas encaminhadas pelo Grupo Mercado Comum. Utilizando-se da prerrogativa de criação de órgãos pertinentes à consecução dos objetivos mercosulinos, o CMC estabeleceu a estruturação de dois órgãos auxiliares: Comissão de Representantes Permanentes e as Reuniões de Ministros do MERCOSUL.

A Comissão de Representantes Permanentes tem origem na Decisão CMC 11/03, a qual, a partir de uma bem sucedida experiência européia, determina a presença constante de representantes nacionais de alto escalão na sede administrativa do MERCOSUL, em Montevidéu, na esperança de que haja, assim, um maior comprometimento e empenho dos Estados-Partes nas negociações conduzidas no seio do bloco. ${ }^{339}$

Por meio da Decisão CMC 05/91, criaram-se as Reuniões de Ministros do MERCOSUL, compostas por ministros dos Estados-Partes ou outros representantes nacionais em nível ministerial, além de representante do Grupo Mercado Comum. Esta prática referendada pelo POP tem por objetivo a melhor articulação de políticas e ações necessárias à consolidação do mercado comum. Esclarece André Ramos que "os 'acordos' firmados, obviamente, não são acordos internacionais, mas sim compromissos políticos que serão adotados posteriormente, quer por Decisão do CMC ou ainda por normas internas pertinentes dos quatro países". ${ }^{340}$ Importante ressaltar a realização periódica da Reunião dos Ministros da Educação (RME), criada ainda em 1991, a qual estudar-se-á mais detidamente adiante.

\footnotetext{
${ }^{339}$ Idem. op. cit. p. 197.

${ }^{340}$ RAMOS, André C. op. cit. p. 198.
} 


\section{3 - Setor Educacional do MERCOSUL - A Educação no Processo de Integração}

Conforme nos ensina Gustavo Fulquet, o primeiro antecedente de um projeto integrativo educacional para a região do Cone Sul remonta ao Protocolo n. 23, intitulado "Regional Fronteiriço", firmado entre representantes dos governos de Brasil e Argentina dentro do contexto do "Programa de Integração e Cooperação Econômica Brasil Argentina", criado pela "Ata de Integração Brasil-Argentina". ${ }^{341} \mathrm{Na}$ tentativa de promover uma aproximação fecunda entre as populações dos dois países nas regiões de fronteira, o Protoloco estabelece a criação de Comitês de Fronteira, as quais cumpririam, entre suas funções, "promover o desenvolvimento econômico, comercial, cultural, educativo, turístico, científico e desportivo". ${ }^{342}$

Contudo, a propositura de um efetivo projeto regional de integração educacional somente conheceria seus contornos com o advento do MERCOSUL. Posto que o objetivo inicial do bloco regional tenha sido eminentemente econômico - a criação de um mercado comum entre os países do bloco, é importante ressaltar que o Tratado de Assunção, em seu preâmbulo, já faz considerações à busca por um desenvolvimento econômico que seja cumulado com justiça social, reconhecendo ainda que a pretendida modernização da economia somente tem por fim a melhoria das condições de vida dos cidadãos dos Estados partícipes. ${ }^{343}$

Diante desta perspectiva mais abrangente de integração econômica, o tema da educação não poderia ser visto como dissociado do projeto encetado pelos Estados-Partes do MERCOSUL. Cientes desta impossibilidade, em abril de 1991, os Ministros de Educação dos Estados do Cone Sul, reunidos em Buenos Aires em razão de um encontro sobre

\footnotetext{
${ }^{341}$ FULQUET, Gastón A. El Proyecto Educativo para el Mercosur y los Debates en torno a la Internacionalización de la Educación Superior. Buenos Aires: CAEI, 2007. p. 13. Este Protocolo pertence foi assinado em 29 de novembro de 1988.

${ }^{342}$ Ver art. $8^{\circ}$ do referido Protocolo. Ainda de acordo com o art. $6^{\circ}$ deste Protocolo, as cidades fronteiriças escolhidas para o início do projeto seriam: Puerto Iguazú e Foz de Iguaçu, Paso de los Libres e Uruguaiana.

${ }^{343}$ Preâmbulo do TA: "Considerando que a ampliação das atuais dimensões de seus mercados nacionais, através da integração, constitui condição fundamental para acelerar seus processos de desenvolvimento econômico com justiça social; (...) Convencidos da necessidade de promover o desenvolvimento científico e tecnológico dos Estados Partes e de modernizar suas economias para ampliar a oferta e a qualidade dos bens de serviços disponíveis, a fim de melhorar as condições de vida de seus habitantes;"
} 
descentralização educacional na região, iniciaram conversas informais a respeito de uma incorporação efetiva da educação no projeto de integração.

O tema voltou à tona por ocasião da realização no Brasil do "Encontro Internacional de Educação, Alfabetização e Cidadania", em meio ao qual acordou-se a formalização de proposta de Acordo Cultural e Educativo no âmbito do MERCOSUL, em maio de 1991.

O passo seguinte, portanto, correspondia à elaboração do projeto de protocolo integrativo educacional. Este documento foi obtido ao final de novo encontro entre representantes ministeriais dos países membros do MERCOSUL, em julho de 1991, em meio à Reunião Preparatória do MERCOSUL Cultural e Educativo, ocorrida em Assunção. ${ }^{344}$ A proposta seria ainda objeto de reflexões em encontro ocorrido em São Paulo, em novembro de 1991.

Sua efetiva estruturação ocorreu ainda no ano de 1991, em 13 de dezembro, por meio da assinatura do "Protocolo de Intenções", documento firmado pelos Ministros de Educação dos quatro países então membros do MERCOSUL. Reconhecia este instrumento, em seu preâmbulo, "que a Educação tem um papel fundamental para que esta integração se consolide e se desenvolva". Ademais, vislumbrava também os princípios e objetivos do SEM, os quais seriam recepcionados pelo Plano Trienal de Ação do Setor Educacional do MERCOSUL aprovado no ano seguinte, conforme veremos de forma mais detida adiante.

Interessante mencionar que esta $1^{\mathrm{a}}$ Reunião de Ministros de Educação ${ }^{345}$ ocorreu antes mesmo de sua previsão normativa no MERCOSUL, uma vez que sua institucionalização somente ocorreu por conta da a Decisão CMC 07/91, datada de 17.12.1991. Diante da imprevisão do órgão, o Protocolo de Intenções mencionava a articulação de uma "Comissão de Ministros de Educação MERCOSUL", a qual detinha funções idênticas ao posterior RME.

\footnotetext{
${ }^{344}$ Cumpre mencionar que este encontro gozou de forte apoio internacional, em especial da Organização de Estados Iberoamericanos (OEI), Organização dos Estados Americanos (OEA), Oficina Regional de Educação para América latina e Caribe da UNESCO (OREALC-UNESCO) e Centro Interamericano de Estudos e Pesquisa para o Planejamento da Educação (CINTERPLAN), Cf. Idem. loc. cit.

345 Conforme já mencionado anteriormente, o Conselho Mercado Comum, órgão de cúpula da estrutura do MERCOSUL, por meio da Decisão CMC 05/91, criou as Reuniões de Ministros do MERCOSUL, não previstas no Tratado de Assunção, porém referendadas pelo Protocolo de Ouro Preto, em seu artigo $8^{\circ}$, inciso VI, com a seguinte redação: "São funções e atribuições do Conselho do Mercado Comum: (...) VI. Criar reuniões de ministros e pronunciar-se sobre os acordos que lhe sejam remetidos pelas mesmas"
} 
Iniciava-se, em menos de um ano portanto, o Setor Educacional do MERCOSUL, encabeçado pela Reunião de Ministros de Educação (RME), a partir do reconhecimento de que uma "formação integral dos recursos humanos mediante a elevação dos níveis de educação é fator essencial para fortalecer o processo de integração e alcançar a prosperidade, o progresso e o bem-estar com justiça social dos habitantes da sub-região". 346

Desta forma, à guisa de conclusão, pode-se dizer que o nascimento do Setor Educacional do MERCOSUL (SEM) remonta à própria gênese do próprio bloco regional, diferentemente do ocorrido no processo integrativo europeu, que colecionou avanços no campo educacional apenas a partir da década de 70, ainda à margem das instituições comunitárias, por meio de reuniões dos Ministros de Educação. ${ }^{347}$

\subsubsection{Estrutura Orgânica}

A estruturação orgânica atual do Setor Educacional do MERCOSUL foi definida em meio aos esforços empreendidos no âmbito do Projeto de Relançamento do MERCOSUL, sendo finalmente aprovada pela Decisão CMC 15/01, em seu Anexo I. Este instrumento previu a conformação das seguintes instâncias para o SEM: (a) Reunião dos Ministros de Educação; (b) Comitê Coordenador Regional; (c) Comissão Regional Coordenadora de Área; (d) Grupo Gestor de Projeto; e (e) Sistema de Informação e Comunicação.

O Setor Educativo do MERCOSUL possui como sua instância máxima a Reunião de Ministros de Educação (RME), órgão incumbido de decidir acerca das contribuições que possa fazer a gestão educativa ao desenvolvimento das políticas do MERCOSUL. ${ }^{348}$ Os acordos obtidos não vinculam diretamente os Estados, de forma que, para tanto, a RME

\footnotetext{
${ }^{346}$ Preâmbulo da Decisão CMC 07/91.

${ }^{347}$ PUÑAL, Antonio Martínez; IGLESIAS, María Teresa Ponte. La Educación en el Proceso de Integración del Mercosur. Santiago de Compostela: Tórculo, 2001. p. 59-60. Ademais, esclarecem os autores que "en efecto, la Europa de la educación comenzó a funcionar en la década de los 70 cuando fueron establecidos una serie de Programas Comunitários de cooperación entre los Estados (Arion, Erasmus, I+D, Comett etc.), creándose a tal fin un órgano básico, el Comité de Educación, integrado por representantes de los Ministerios de Educación de los Estados miembros y de la Comissión Europea. Posteriormente, las reuniones de los Ministros de Educación se integraron en el marco comunitario a través de las reuniones del Consejo de Ministros de Educación reunidos en el seno del Consejo", $C f$. PUÑAL, Antonio Martínez; IGLESIAS, María Teresa Ponte. op. cit. p. 60 , nota 74 .

${ }^{348}$ Decisão CMC 15/01, Anexo I, item 1. Até o presente momento, foram realizados 37 encontros da RME.
} 
realiza propositura, ao Conselho Mercado Comum, por meio do Grupo Mercado Comum, de medidas visando à coordenação de políticas educacionais nos Estados-Partes. ${ }^{349}$ Todavia, nos demais casos, a RME possui poder decisório pleno, como na elaboração de planos específicos para o setor.

Composta apenas pelos Ministros de Educação dos Estados-Partes e associados ao MERCOSUL, a RME reúne-se todas as vezes que se julgar necessário e ao menos uma vez por ano. Todavia, usualmente estes encontros ocorrem duas vezes por ano. Sua presidência é exercida pelo Ministro do Estado que ocupar a Presidência Pro Tempore do bloco regional, alternando-se, portanto, a cada seis meses seguindo a ordem alfabética. ${ }^{350}$

Desde o início da estruturação do SEM, vislumbrava-se a criação do Comitê Coordenador Regional (CCR), enquanto instância executiva, estratégica e política de assessoria à RME em suas atividades. Atualmente, o CCR é responsável por propor políticas de integração e cooperação no âmbito da educação e coordenar o desenvolvimento da atuação do SEM. A composição do Comitê apresenta representantes das Comissões Nacionais Educacionais para a integração no MERCOSUL, instâncias nacionais criadas para auxiliá-lo em seus objetivos. ${ }^{351}$

A atuação do CCR desdobra-se tanto em atividades propriamente de gestão, como na supervisão e avaliação das atividades desempenhadas pelas outras instâncias de trabalho do setor, quanto na de representação, ao estabelecer relações, em nome do setor, com o restante do MERCOSUL, outros organismos internacionais e sociedade civil. Ademais, é também responsável por desenvolver um Programa Anual de atividades e o Plano de Ação para o Setor. Outrossim, possui competência para a criação de outras instâncias necessárias para o cumprimento de suas funções. ${ }^{352}$

\footnotetext{
${ }^{349}$ Consoante o que já estava disposto no art. $1^{\text {o }}$ da Decisão CMC 07/91.

${ }^{350}$ Ademais, cabe ao Estado que preside o Setor Educacional do MERCOSUL manter comunicação permanente com as delegações dos países integrantes, organizar as reuniões do setor em todos os níveis, arquivar a documentação oficial durante o período e remetê-la aos órgãos competentes, realizar uma transição ordenada de gestão e informar as questões pendentes à presidência entrante, $C f$. Decisão CMC 15/01, Anexo I, item 2.

351 CASTRO, Ana Maria. "Estado Del Arte de la Negociación en Educación". In: CHIARELLI, Carlos A.; SIENRA, Jorge (orgs.). A Educação em um Processo de Integração. São Paulo: LTr, 2001.p. 73.

352 As funções do CCR são as seguintes: “a) Actuar como canal de comunicación orgánica del SEM con la estructura institucional del Mercosur global, en especial en lo referente a la Reunión de Ministros de Educación; b) Establecer relaciones y gestionar articulaciones con organismos internacionales de cooperación y financiamiento, agencias especializadas, instituciones y actores de la sociedad civil; c) Proponer, aprobar, y evaluar los programas, proyectos y acciones, estableciendo las prioridades y las responsabilidades,
} 
Para o melhor desenvolvimento e acompanhamento das políticas educacionais nos diferentes níveis de ensino, previram-se a criação de três Comissões Regionais Coordenadoras de Área (CRCA), instâncias técnicas, distintas entre si de acordo com sua especificidade educacional: (a) CRC de Educação Básica (CRC-EB); (b) CRC de Educação Tecnológica (CRC-ET); e (c) CRC de Educação Superior (CRC-ES). Estas instâncias dependentes do CCR são responsáveis por planificar e implementar as linhas de ação em cada nível de ensino, bem como acompanhar e avaliar os projetos desenvolvidos. ${ }^{353}$

A elaboração dos projetos, contudo, é atribuição dos Grupos Gestores de Projeto $\underline{(\mathrm{GGP})}$, que são instâncias temporais específicas, convocadas ad hoc, por iniciativa própria do CCR ou ainda por sugestão das CRCA, tendo como finalidade precípua a elaboração dos perfis e desenvolvimento dos projetos aprovados pelo setor. ${ }^{354}$

A fim de providenciar uma compilação e armazenamento efetivo de dados comparáveis e confiáveis sobre a educação no MERCOSUL, previu-se a criação do Sistema de Informação e Comunicação (SIC), almejando munir outras instâncias do SEM com dados e informações quantitativas e qualitativas para a gestão de programas e ações do setor, além de fomentar a comunicação e discussão entre os atores dos sistemas educacionais da região. ${ }^{355}$ A sua atuação, como instância comum a todos os comitês técnicos do setor, tem auferido importantes resultados, por meio do apoio de contrapartes nacionais. Destaca-se, neste sentido, a publicação anual da Vitrine Estatística, responsável pela apresentação de

contemplando la transversalidad en función de las líneas estratégicas que los enmarcan; d) Identificar los mecanismos de financiamiento y las fuentes de recursos que permitan la implementación de los programas y proyectos prioritarios del SEM; e) Procesar la información derivada a través de las Actas, Informes Ejecutivos y otros provenientes de las diferentes instancias del SEM; f) Elaborar un Programa Anual y un calendario de actividades, en el marco del Plan de Acción; g) Difundir, en términos generales y específicos, los avances del proceso de integración y, en especial, los resultados de los estudios y proyectos realizados en el ámbito de su actuación; h) Elevar a la consideración de la Reunión de Ministros las Propuestas de Acuerdos derivados de las actividades de asesoría y coordinación general; i) Crear las instancias necesarias para el adecuado cumplimiento de sus atribuciones; j) Supervisar y evaluar el funcionamiento de las instancias de trabajo del SEM; $k$ ) Informar a la Reunión de Ministros sobre los avances y la aplicación de los acuerdos de política educativa, así como rendir cuenta de su trabajo en cualquier momento que se le requiera; 1) Resolver situaciones no contempladas en su Reglamento, en el ámbito de sus competencias; m) Cumplir toda otra función que la Reunión de Ministros le encomiende", $c f$. Decisão CMC 15/01, Anexo I, item 2.

${ }^{353}$ Ver Decisão CMC 15/01, Anexo I, item 3. Até 2001, as CRCAs atendiam pela nomenclatura de Comissão Técnica Regional, existindo em número de seis, as quais foram absorvidas pelas atuais instâncias.

${ }^{354}$ Ver Decisão CMC 15/01, Anexo I, item 4. Até 2001, a nomenclatura era Grupos de Trabalho.

${ }^{355}$ Ver Decisão CMC 15/01, Anexo I, item 5. 
dados e indicadores educativos atualizados dos países membros e associados ao bloco regional. ${ }^{356}$

À guisa de conclusão, apresentamos o organograma oficial do Setor Educacional do MERCOSUL, em figura colacionada abaixo.

Em virtude da institucionalização do financiamento ao SEM, a Decisão CMC 05/06 acrescentou à estrutura orgânica do setor o Comitê Assessor do Fundo Educativo do MERCOSUL (CAFEM), cuja função principal é formular estratégias de captação de recursos públicos e privados, bem como assessorar o organismo administrador do FEM em matéria financeira, avaliando periodicamente a administração de recursos por parte deste. ${ }^{357}$

No último Plano do Setor Educacional do MERCOSUL, aprovado em 2006, encontrase novamente uma reflexão acerca de uma eventual reestruturação orgânica do bloco, diagnosticada como necessária para fazer frente a um suposto "déficit institucional" que atingiria o próprio MERCOSUL. O documento prevê a mitigação dos efeitos negativos deste déficit por meio da criação de uma estrutura permanente para o SEM, além da adoção de uma aproximação mais enfática com outros órgãos do bloco regional, como as outras Reuniões de Ministros.

Sugere-se, outrossim, a apresentação sistemática, pela RME, dos informes mais relevantes do SEM ao Conselho Mercado Comum. Consoante o exposto no mencionado Plano, tal medida concederia maior flexibilidade e agilidade às ações do SEM, garantindo "la correcta valorización de los temas no estrictamente comerciales, y permitiría jerarquizar la dimensión social del MERCOSUR". 358

\footnotetext{
356 Informa-nos Fatima Anastasia que para a obtenção destes dados foi desenvolvido um projeto intitulado "Sistema de Indicadores do MERCOSUL Indicativo", sob coordenação de um GGP, com duração entre 1998 e 2003. O mencionado projeto "resultou na definição de uma metodologia de padronização dos níveis educacionais e de um conjunto de 15 indicadores, incluindo indicadores globais (contexto socioeconômico) e específicos (educacionais)", $C f$. ANASTASIA, Fatima et alli. op. cit. p. 56.

${ }^{357}$ Decisão CMC 05/06, art. $2^{\circ}$ : "São funções do CAFEM: a)recomendar em matéria financeira tudo o que for pertinente ao FEM; b) articular com o organismo administrador do FEM tudo o que disser respeito à administração de Fundos, avaliar periodicamente o comportamento e a administração de recursos por parte do mesmo; e informar semestralmente à Reunião de Ministros da Educação; c) formular e implementar estratégias para a obtenção de recursos extraordinários provenientes de terceiros países, de outros organismos e do setor privado; e d) estabelecer contatos com os administradores dos Fundos Estruturais do MERCOSUL, mantendo o Comitê Coordenador Regional (CCR) informado".

${ }^{358}$ Plano do Setor Educacional do MERCOSUL 2006-2010, p.22.
} 
Ademais, sugere o mesmo plano que se vislumbre a identificação e incorporação de novos atores educacionais ao processo integrativo, buscando sempre conceder maior eficácia e extensão às ações do SEM, com efeitos visíveis dentro das salas de aulas dos países do bloco. Adverte o documento, pois, contra uma identificação do setor apenas com acordo superestruturais, sem o impacto pretendido nos sistemas educativos nacionais. ${ }^{359}$

F.1 - Organograma do $\mathrm{SEM}^{360}$

\section{Setor Educacional do Mercosul}

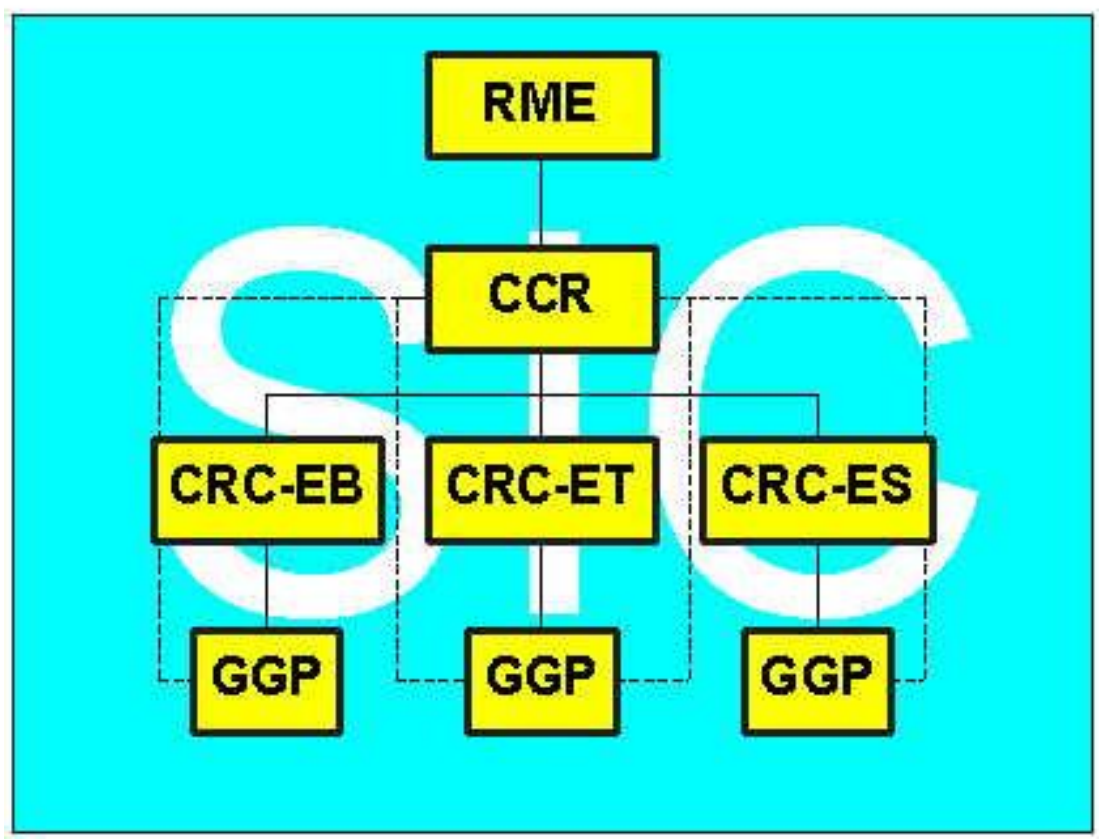

\subsubsection{Financiamento do SEM}

Diante das inúmeras atividades empreendidas pelo SEM e de sua relevância, a elaboração do Terceiro Plano do Setor Educativo do MERCOSUL (2001-2005), importou na reestruturação orgânica e financeira do setor, de modo a capacitá-lo administrativa e

\footnotetext{
${ }^{359}$ Plano do Setor Educacional do MERCOSUL 2006-2010, p.23.

${ }^{360}$ Organograma retirado da página eletrônica do MERCOSUL Educacional, hospedada na plataforma do INEP, com acesso em 30.01.2010:

http://www.sic.inep.gov.br/index.php?option=com_content\&task=view\&id=52\&Itemid=75
} 
financeiramente para a realização de suas tarefas. Em sua introdução, como justificativa, o Plano defende que o SEM seja capaz de

\begin{abstract}
"fazer frente aos desafios de incorporar novos atores educacionais ao processo de integração, promover a articulação eficiente com as demais instâncias do MERCOSUL e, sobretudo, reconhecer a instituição educativa como espaço cultural privilegiado para a formação de uma consciência favorável à integração regional, que repercuta significativamente na escola como núcleo básico"361.
\end{abstract}

A despeito da urgência com a qual é tratado o tema do financiamento do SEM neste documento, a aprovação do Fundo de Financiamento do Setor Educacional do MERCOSUL (FEM) ocorreu apenas por meio da Decisão CMC 33/04, datada de 16.12.2004, onde se estabeleceu que o objetivo do FEM é "financiar os programas e projetos do Setor Educacional do MERCOSUL que fortaleçam o processo de integração regional", ${ }^{362}$

Apesar de reconhecer que cabe à Reunião de Ministros de Educação do MERCOSUL definir a distribuição de recursos para os programas e projetos do SEM, optou-se pela adoção de uma administração especializada do Fundo, realizada por organismo escolhido especificamente pela RME para este fim, a partir de regras estipuladas em um "Contrato de Administração do Fundo para o Setor Educacional do MERCOSUL". ${ }^{363}$ Atualmente, a Cooperação Andina de Fomento (CAF) exerce a administração do FEM, gestão recentemente prorrogada por mais um ano. ${ }^{364}$

A composição do capital do fundo admite contribuições dos Estados-Partes e Associados $^{365}$ ao bloco regional, além da contribuição extraordinária de países terceiros, outros organismos, setor privado e rendimentos do próprio fundo. Os Estados deverão realizar suas contribuições anuais no primeiro semestre de cada ano, sendo que, para os primeiros quatro anos, estas serão calculadas a partir de dois aportes: o primeiro representa aporte mínimo fixo, dividido em cotas iguais entre os Estados participantes do FEM, no valor

\footnotetext{
${ }^{361}$ Anexo II da Decisão CMC 15/01 - Plano Trienal do Setor Educativo do MERCOSUL 2001-2005, Introdução.

${ }^{362}$ Decisão CMC 33/04, art.1 ${ }^{\circ}$. Ver também a Decisão CMC 24/08, que reformula o Regulamento do Fundo de Financiamento do SEM, bem como revoga alguns artigos da Decisão CMC 33/04.

${ }^{363}$ Decisão CMC 24/08, Anexo I, arts. $8^{\circ}$ e $9^{\circ}$.

${ }^{364}$ O Convênio entre o MERCOSUL e a CAF foi celebrado em 18.10.2005, com previsão de quatro anos de duração. Sobre a prorrogação, consultar MERCOSUL/CMC/RME/Ata n. 02/09, por ocasião da XXXVII RME, realizada em 20.11.2009.

${ }^{365}$ A participação dos Estados Associados é facultativa, de forma que o Estado Associado interessado em participar deve seguir as regras previstas para a assinatura de acordos celebrados com os Estados Associados no MERCOSUL, dispostas na Decisão CMC 28/04.
} 
US\$ 180.000,00 (cento e oitenta mil dólares estadunidenses); já o segundo é composto por uma contribuição proporcional de US\$2.200,00 (dois mil e duzentos dólares estadunidenses) para cada milhão de habitante em idade escolar, conforme a fonte oficial de dados de cada país, no ano de $2006 .{ }^{366}$ Destarte, à guisa de informação, colocamos abaixo a disposição e participação de cada Estado no orçamento do FEM:

Q.25 - Projeção de Contribuições Anuais por País ao FEM

\begin{tabular}{|c|c|c|c|c|}
\hline País & $\begin{array}{c}\text { População em } \\
\text { idade escolar } \\
(\mathbf{m i})\end{array}$ & $\begin{array}{c}\text { Aporte } \\
\text { Mínimo }\end{array}$ & $\begin{array}{c}\text { Aporte } \\
\text { Proporcional }\end{array}$ & Total \\
\hline Argentina & 12,5 & US\$ 30.000,00 & US\$ 27.500,00 & US\$ 57.500,00 \\
\hline Bolívia & 3,0 & US\$ 30.000,00 & US\$ 6.600,00 & US\$ 36.600,00 \\
\hline Brasil & 60,0 & US\$ 30.000,00 & US\$ 132.000,00 & US\$ 162.000,00 \\
\hline Chile & 4,0 & US\$ 30.000,00 & US\$ 8.800,00 & US\$ 38.800,00 \\
\hline Paraguai & 2,0 & US\$ 30.000,00 & US\$ 4.400,00 & US\$ 34.400,00 \\
\hline Uruguai & 0,6 & US\$ 30.000,00 & US\$ 1.320,00 & US\$ 31.320,00 \\
\hline Total & $\mathbf{8 2 , 1}$ & US\$ 180.000,00 & US\$ 180.620,00 & US\$ 360.620,00 \\
\hline
\end{tabular}

\section{$\underline{\text { 3.3.3 Evolução das Atividades do SEM }}$}

A seguir, procederemos à análise das atividades desenvolvidas no seio do Setor Educacional do MERCOSUL, por meio de uma perspectiva histórico-evolutiva, tendo como foco de estudo os quatro Planos de Ação aprovados pela RME até o presente momento. Paralelamente a este estudo, destacaremos as ações específicas empreendidas para a educação básica, bem como os avanços alcançados em cada período.

\footnotetext{
${ }^{366}$ É forçoso informar que o atual desenho das contribuições estatais ao FEM foi apresentado na VI Reunião do CAFEM, realizada em agosto de 2006. Substituía a proposta anterior, que antevia a distribuição do aporte fixo de US\$180.000,00 (cento e oitenta mil dólares estadunidenses) proporcionalmente entre os países, proposta esta que foi apresentada pela delegação brasileira, quando da $44^{\mathrm{a}}$. Reunião do Comitê Coordenador Regional. Frisese a recomendação do Banco Interamericano de Desenvolvimento no sentido de incluir uma contribuição mínima por país, a qual foi mantida na revisão - $C f$. ANASTASIA, Fátima et alli. op . cit. p. 60.

${ }^{367} \mathrm{O}$ art. $4^{\circ}$., "b", do Regulamento do Fundo do FEM esclarece que serão consideradas neste cálculo pessoas com idades entre 5 e 24 anos.
} 
a) Primeiro Plano Trienal (1991-1998)

Em função da rápida articulação do SEM, a RME submete, em 1992, o primeiro Plano Trienal à apreciação do Grupo Mercado Comum e posterior consideração por parte do Conselho Mercado Comum, o qual reconhece em sua decisão favorável, que "a formação da consciência cidadã favorável ao processo de integração, assim como a capacitação de recursos humanos e a conciliação e harmonização dos sistemas educativos dos EstadosPartes constituem alicerces fundamentais para a conformação do Mercado Comum do Sul (MERCOSUL)",368

Sem embargo, este Plano Trienal ${ }^{369}$ condensava em três ambiciosos programas os objetivos iniciais para a educação no MERCOSUL, sem apontar pragmaticamente estratégias para a consecução destes:

\footnotetext{
"Programa I - Formação da consciência cidadã favorável ao processo de integração

Tem por finalidade promover o conhecimento do impacto da integração e difundir esta informação nos diferentes níveis do sistema educativo e implementar o ensino do Espanhol e do Português em instituições dos diferentes níveis e modalidades do sistema educativo.
}

Programa II - Capacitação de recursos humanos para contribuir ao desenvolvimento

Seu objetivo é promover estratégias de desenvolvimento educativo para o ensino básico e médio, para a formação técnico-profissional e de alto nível.

Programa III - Compatibilização e harmonização dos sistemas educativos

Persegue a proposição de mecanismos jurídicos, administrativos e acadêmicos que possibilitem a compatibilização dos sistemas educativos e o estabelecimento de um sistema de informação em rede que possibilite conhecer os dados educativo relevantes dos Estados-Partes.",370

\footnotetext{
${ }^{368}$ Decisão CMC 07/92, datada de 27.06.1992. Grifos nossos.

${ }^{369}$ O presente plano seria prorrogado até 31 de dezembro de 1997, na VII Reunião do RME, bem como novamente pela Decisão CMC 25/97, até 30 de junho de 1998. Mais a respeito, bem como um balanço das atividades desempenhadas pelo órgão no primeiro triênio, pode ser encontrado em MERCOSUL/RME/Ata n. 06/94, datada de 09.12.1994.

${ }^{370}$ Decisão CMC 07/92, Anexo I. Para um estudo aprofundado destes programas, ver CASTRO, Ana Maria. op. cit. pp.61-72. Ou ainda: SANTANA, Josefina Maria de. "O MERCOSUL: Educação e as Universidades". In: CASELLA, Paulo Borba (coord.). MERCOSUL - Integração Regional e Globalização. Rio de Janeiro: Renovar, 2000. p. 1023-1029.
} 
Destaca-se, no entanto, o deferimento feito ao ensino básico, por meio da promoção de estratégias específicas para o seu desenvolvimento. Este deferimento também se reflete na primeira grande medida aprovada pelo MERCOSUL a respeito da educação: "Protocolo sobre Integração Educativa e Reconhecimento de Certificados, Títulos e Estudos de Nível Primário e Médio Não-Técnico", aprovado pela Decisão CMC 04/94, datada de 05.08.1994.

Neste instrumento determina-se a validação e equiparação de estudos nos níveis fundamental e médio, cursados nos países do bloco, para efeitos de prosseguimento de estudos, por meio da outorga de validade intrabloco aos certificados de estudos expedidos pelas instituições de ensino oficialmente reconhecidas em cada um dos Estados partícipes. Para tanto, previu-se a criação de uma Comissão Regional Técnica responsável pela compatibilização dos currículos, perfis e competências para estes níveis de escolarização, bem como velar pelo cumprimento do Protocolo. ${ }^{371}$

Trata-se, na verdade, da realização do desiderato exposto em ata da RME cerca de um ano e meio antes, ${ }^{372}$ onde se concedeu ênfase à integração da educação básica prioritariamente sobre os outros níveis, os quais também receberam tratamento equânime, porém posterior, como o caso do ensino médio técnico ${ }^{373}$ e superior $^{374}$.

Paralelamente ao cumprimento do Primeiro Plano Trienal estabelecido, data também deste período a aproximação do SEM com organismos internacionais, com vistas a

\footnotetext{
${ }^{371}$ Diz artigo $3^{\circ}$. do mencionado Protocolo: "Com o objetivo de estabelecer as denominações equivalentes dos níveis de educação de cada um dos Estados-Partes, de harmonizar os mecanismos administrativos que facilitem o desenvolvimento do que foi estabelecido, de criar mecanismos que favoreçam a adaptação dos estudantes no país receptor, de resolver aquelas situações que não estiverem contempladas pelas Tabelas de Equivalências e de velar pelo cumprimento do presente Protocolo, será criada uma Comissão Regional Técnica que poderá reunirse toda vez que pelo menos dois dos Estados-Partes considerarem necessário. A Comissão Regional Técnica será integrada por delegações dos Ministérios da Educação de cada um dos Estados-Partes e sua coordenação caberá aos setores competentes das respectivas Chancelarias. Os locais de reunião serão estabelecidos de forma rotativa nos territórios de cada um dos Estados-Partes".

${ }^{372}$ Mais a esse respeito em MERCOSUL/RME/Ata n. 02/92, datada de 27.11.1992.

${ }^{373}$ Ver Decisão CMC 07/95, a qual aprovou o "Protocolo de Integração Educativa e Revalidação de Diplomas, Certificados, Títulos e Reconhecimento de Estudos de Nível Médio Técnico", datado de 05.08 .1995

${ }^{374}$ Ver Decisão CMC 08/96, a qual aprovou o "Protocolo de Integração Educacional para Prosseguimento de Estudos de Pós-Graduação nas Universidades dos Estados-Partes do MERCOSUL”, datado de 17.12.1996. Este Protocolo revogou a disposição anterior sobre a matéria, prevista na Decisão CMC 04/95. Também acerca do ensino em pós-graduação, destaca-se a Decisão CMC 09/96, que aprovou o "Protocolo de Integração Educacional para a Formação de Recursos Humanos no Nível de Pós-Graduação entre os Estados-Partes do MERCOSUL", datado de 17.12.1996, cujo objetivo é a criação de um sistema de intercâmbio entre as instituições de ensino superior do bloco regional, voltado para docentes e pesquisadores. Com relação, ao ensino superior em graduação, menciona-se a aprovação, pela Decisão CMC 03/97, do "Protocolo de Admissão de Títulos e Graus Universitários para o Exercício de Atividades Acadêmicas nos Estados-Partes do MERCOSUL", datado de 18.06.1997.
} 
colaboração e desenvolvimento de projetos educacionais na região. Destacam-se, neste campo, os convênios aprovados com a UNESCO, OEI, Convênio Andrés Bello e a União Européia. $^{375}$

Outro marco de significativa relevância para o SEM veio a lume em 20.06.1996, quando a RME aprovou o documento "MERCOSUL 2000: Desafios e Metas para o Setor Educativo". Este instrumento identificou áreas prioritárias para as políticas educacionais da região, dentre outras: o processo de avaliação educacional, a renovação de práticas de ensino, o aperfeiçoamento do ensino técnico-profissional, a cooperação universitária e o desenvolvimento de um sistema de informações educacionais.

Percebe-se ao final deste período, portanto, uma preocupação ainda incipiente, por parte do SEM, em influenciar e articular as políticas educacionais nacionais da região. Para Ana Maria Castro, esta mudança de postura reflete a divisão entre duas etapas nas atividades empreendidas pelo Setor Educacional:

"Esto establece el fin de la primera etapa y el inicio de una segunda etapa del Sector Educativo del Mercosur que estuvo caracterizada por la construcción de un instrumento institucional básico y la armonización de los sistemas y procesos educativos de los Estados Miembros, formalizados en los distintos Protocolos firmados, e iniciar una segunda etapa que ejecute políticas de impacto directo como respuesta a las necesidades de la Región". ${ }^{376}$

b) Segundo Plano Trienal (1998-2000)

Diante do sucesso obtido ao longo dos primeiros anos do bloco, a XV Reunião do Conselho Mercado Comum, realizada no Rio de Janeiro, em 10.12.1998, aprovou novo Plano Trienal para a Educação (1998-2000) no bloco regional, além de reconhecer os inúmeros avanços obtidos pela Reunião de Ministros do MERCOSUL até aquele presente momento. ${ }^{377}$

\footnotetext{
375 Para uma análise mais aprofundada do relacionamento externo do SEM durante o período, ver CASTRO, Ana Maria. op. cit. p. 88-90.

${ }^{376}$ Idem. op. cit. p. 68.

377 Ver Anexo da Decisão CMC 13/98. Neste documento, em sua primeira parte, reconhecem-se os seguintes avanços na área educacional do bloco: “(I) aprovação de protocolos que facilitam o reconhecimento e equiparação de estudos e a livre circulação de estudantes; (II) início de trabalhos de adequação dos currículos de educação básica, no que se refere à aprendizagem das línguas oficiais do MERCOSUL e ao ensino de História e Geografia, e dos currículos de formação técnico-profissional, na perspectiva da formação por competência; (III)
} 
Este novo documento também identifica clara e sucintamente a missão específica do Setor Educacional do MERCOSUL e os princípios norteadores de sua atuação, a saber:

\section{Q.26 - Principais Aspectos do Plano Trienal do SEM (1998-2000)}

\begin{tabular}{|c|c|}
\hline Missão $^{378}$ & Princípios $^{379}$ \\
\hline $\begin{array}{l}\text { Contribuir para os objetivos do MERCOSUL, } \\
\text { estimulando a formação da consciência cidadã para a } \\
\text { integração e promovendo educação de qualidade para } \\
\text { todos, num processo de desenvolvimento com justiça } \\
\text { social e conseqüente com a singularidade cultural de } \\
\text { seus povos }\end{array}$ & $\begin{array}{l}\text { (I) Integração regional e respeito à diversidade: o } \\
\text { Setor Educacional do MERCOSUL contribui para a } \\
\text { consecução dos objetivos do Mercado Comum do Sul, } \\
\text { no sentido assinalado pelo Protocolo de Intenções } \\
\text { firmado em dezembro de 1991, e reconhece, ao } \\
\text { mesmo tempo, a soberania e o direito à } \\
\text { autodeterminação de que goza cada um dos Estados } \\
\text { participantes, bem como as múltiplas expressões } \\
\text { culturais presentes na região; } \\
\text { (II) Compromisso democrático: o Setor Educacional } \\
\text { do MERCOSUL auxilia na criação das condições para } \\
\text { que os sistemas educacionais sejam um instrumento } \\
\text { eficaz na promoção dos valores democráticos que os } \\
\text { Presidentes dos países do MERCOSUL consagraram } \\
\text { com a assinatura do documento "Compromisso } \\
\text { Democrático"380; e, } \\
\text { (III) Educação de qualidade para todos: o Setor } \\
\text { Educacional do MERCOSUL é uma instância } \\
\text { privilegiada para favorecer a melhoria continuada dos } \\
\text { níveis de qualidade da educação ministrada na região, } \\
\text { com sentido de equidade, promovendo e aproveitando } \\
\text { adequadamente a cooperação entre os Estados-Partes } \\
\text { e o apoio de organismos multilaterais e } \\
\text { internacionais" }\end{array}$ \\
\hline
\end{tabular}

É mister mencionar que o documento adota ao longo de seu texto uma visão instrumental da educação, relacionando-a constantemente à necessidade de capacitação de recursos humanos técnicos necessários para apoiar o intento integracionista e fazer frente às

aprovação de protocolos para facilitar o intercâmbio de docentes universitários e a formação de recursos humanos em nível de pós-graduação; (IV) constituição do Sistema de Informação e Comunicação do Setor Educacional do MERCOSUL; e (V) elaboração de um mecanismo de credenciamento de cursos universitários" (Termos de Referência para a Definição do Plano Trienal do Setor Educacional do MERCOSUL, 1998-2000, item 06).

${ }^{378}$ Decisão CMC 13/98, Anexo I, Primeira Parte - Termos de Referência para a Definição do Plano Trienal do Setor Educacional do MERCOSUL, 1998-2000, item 07.

${ }^{379}$ Decisão CMC 13/98, Anexo I, Primeira Parte - Termos de Referência para a Definição do Plano Trienal do Setor Educacional do MERCOSUL, 1998-2000, item 08.

${ }^{380}$ Em referência ao Protocolo de Ushuaia, sobre o qual já tratamos anteriormente. 
novas exigências de um mundo regionalizado, justificando-se a partir da identificação desta tendência a necessidade de uma melhor qualidade da educação. ${ }^{381}$

Diferentemente do Plano Trienal anterior, contudo, buscou pragmaticamente apontar linhas de atuação e metas que favorecessem o "desenvolvimento da identidade regional por meio do estimulo ao conhecimento mútuo e a uma cultura da integração" e a "promoção de políticas regionais de capacitação de recursos humanos e melhoria da qualidade da educação", elevadas a áreas prioritárias pelo documento. ${ }^{382}$

Sem mencionar especificamente a educação básica, o Plano prevê, entre suas metas, o incentivo ao desenvolvimento de redes e programas regionais que colaborem com o intercâmbio de docentes, pesquisadores e estudantes de todos os níveis de ensino, de modo a preparar e estimular a vivência da integração. ${ }^{383}$ Há, outrossim, uma preocupação com a definição de indicadores de qualidade comuns em todos os níveis e modalidades de ensino na região. $^{384}$

Contudo, apesar dos poucos avanços alcançados no nível de educação básica ao longo do período, destaca-se a deferência a ela dispensada na proclamação na "Carta de Buenos

\footnotetext{
${ }^{381}$ Anexo Decisão CMC 13/08 - Primeira Parte: “9. O planejamento para o triênio 1998-2000 reconhece o valor intrínseco dos instrumentos de integração educacional para potencializar a integração econômica, particularmente quando os resultados da globalização levantam algumas críticas, uma vez que a inserção dos sistemas político-econômicos nacionais numa economia mundial não garante, por si só, nem o crescimento nem o desenvolvimento. Nesta perspectiva, o Setor Educacional do MERCOSUL reconhece que o poder de concorrência de um país ou bloco de países no mercado, imposto pela globalização da economia, vê-se cada vez mais determinado pela qualidade dos recursos humanos, pelo conhecimento, a ciência e a tecnologia aplicada aos métodos de produção, e menos pela disponibilidade de mão-de-obra barata e pela existência de recursos naturais" (grifos nossos). Em dissertação de mestrado acerca do tema, Mário Barboza aduz que os planos educacionais do MERCOSUL reproduzem a teoria do capital humano, pela qual o investimento em educação representaria, na verdade, um investimento econômico, tem em vistas aos potenciais ganhos em capacidade e produtividade. Para o autor, portanto, a educação figura como mero adereço econômico neste processo integracionista. Cf. BARBOZA, Mário de Jesus. Política de Educação nos Planos do Setor Educacional do MERCOSUL - A Educação como Elemento de Integração e Desenvolvimento Regional. Dissertação de Mestrado, Universidade do Oeste do Paraná - UNIOESTE, Cascavel, 2009.

${ }^{382}$ Ver Segunda Parte do Anexo da Decisão CMC 13/98, intitulada "Plano Trienal 1998-2000 do Setor Educacional do MERCOSUL".

${ }^{383}$ Contudo, foi feita uma deferência especial ao ensino superior, por meio da previsão de criação de um sistema de transferência de créditos acadêmicos, com vistas a favorecer a mobilidade de alunos de graduação e pósgraduação dos Estados-Partes. Neste sentido, foi aprovado no triênio em questão o "Acordo de Admissão de Títulos e Graus Universitários para o Exercício de Atividades Acadêmicas nos Estados-Partes do MERCOSUL" (Decisão CMC 04/99), que revogou a disposição anterior sobre a matéria, prevista na Decisão CMC 03/97. O "Acordo de Admissão de Títulos e Graus Universitários para o Exercício de Atividades Acadêmicas nos Estados-Partes do MERCOSUL, na República da Bolívia e na República do Chile" (Decisão CMC 05/99) estendeu os benefícios para os Estados associados ao MERCOSUL.

${ }^{384}$ É neste contexto em que se insere o desenvolvimento do projeto "Sistema de Indicadores do MERCOSUL", ao qual já nos referimos anteriormente.
} 
Aires sobre Compromisso Social no MERCOSUL, Bolívia e Chile" da necessidade de "garantir o direito à educação básica e favorecer o acesso à educação secundária, técnica e vocacional, sendo ambos elementos chaves na superação da pobreza como veículos de mobilidade social e econômica". 385

c) Terceiro Plano do SEM (2001-2005)

O Plano do Setor Educativo do MERCOSUL para os anos compreendidos entre 2001 e 2005 encontra-se no Anexo II da Decisão CMC 15/01, datada de 20 de dezembro de 2001. O teor do plano encontra-se em consonância com as aspirações proferidas pelos Ministros da Educação dos países do MERCOSUL quando de seu encontro em Gramado, ao final do qual apresentou-se o Compromisso de Gramado, elevado a marco referencial para a definição do plano de ação do SEM.

Com relação à sua estrutura, o presente documento, assim como anterior, também promove um balanço dos avanços alcançados até aquele presente momento, estabelecendo, também, nova missão para o SEM, bem como novos princípios e objetivos, conforme podemos ver a seguir:

\section{Q. 27 - Principais Aspectos do Plano do SEM 2001-2005 ${ }^{386}$}

\begin{tabular}{|c|c|c|}
\hline Missão & Princípios Orientadores & Objetivos Estratégicos \\
\hline $\begin{array}{l}\text { Contribuir aos objetivos do } \\
\text { MERCOSUL, conformando um } \\
\text { espaço educativo comum, } \\
\text { estimulando a formação da } \\
\text { consciência cidadã para a } \\
\text { integração, a mobilidade e os } \\
\text { intercâmbios com o objetivo de } \\
\text { obter uma educação de qualidade } \\
\text { para todos, com atenção especial }\end{array}$ & $\begin{array}{l}\text { Agenda do SEM vinculada às políticas } \\
\text { educacionais nacionais, para lograr } \\
\text { maior impacto nos sistemas educativos } \\
\text { e no conjunto da sociedade; A } \\
\text { educação como espaço cultural para o } \\
\text { fortalecimento de uma consciência } \\
\text { favorável à integração que valore a } \\
\text { diversidade e a importância dos } \\
\text { códigos culturais e linguísticos; O } \\
\text { processo de integração se fortalece na } \\
\text { instituição educativa para impactar } \\
\text { fortemente nas instituições educativas, } \\
\text { especialmente nos níveis primário e } \\
\text { médio; A integração exige educação de } \\
\text { qualidade para todos para atender às } \\
\text { necessidades educativas dos setores }\end{array}$ & $\begin{array}{l}\text { Fortalecimento da consciência cidadã } \\
\text { favorável ao processo de integração } \\
\text { regional, que valore a diversidade cultural; } \\
\text { Promoção de uma educação de qualidade } \\
\text { para todos na região e de políticas de } \\
\text { formação e capacitação de recursos } \\
\text { humanos competentes; e, } \\
\text { Conformação de um espaço } \\
\text { educativo regional de cooperação } \\
\text { solidária }\end{array}$ \\
\hline
\end{tabular}

${ }^{385}$ Carta assinada em 30 de junho de 2000, estabelecendo ainda que o Foro de Consulta e Concertação Política do MERCOSUL, Bolívia e Chile seja responsável por dar prosseguimento aos objetivos erigidos no documento, além de institucionalizar reunião entre as autoridades nacionais responsáveis pelo desenvolvimento social. Texto retirado, em acesso datado de 30.01.2010, da página eletrônica:

http://www.urjc.es/ceib/espacios/observatorio/cohesion/documentos/procesos_integracion/SOC-I-07.pdf

386 Definições retiradas do Anexo II da Decisão CMC 15/01 - Plano Trienal do Setor Educativo do MERCOSUL 2001-2005. 


\begin{tabular}{|c|c|c|}
\hline aos setores mais vulneráveis, em & $\begin{array}{c}\text { mais vulneráveis a fim de superar as } \\
\text { inequidades existentes; O } \\
\text { um processo de desenvolvimento } \\
\text { fortalecimento do diálogo com a } \\
\text { sociedade para envolver aos mais } \\
\text { distintos atores educativos no processo } \\
\text { de integração; A mobilidade e } \\
\text { diversidade cultural dos povos da } \\
\text { intercâmbio de atores educativos para } \\
\text { o desenvolvimento e fortalecimento de } \\
\text { região }\end{array}$ & \\
\hline
\end{tabular}

Outrossim, percebe-se neste documento, ao contrário do anterior, uma visão mais propositiva ou menos instrumentalizada da educação, reconhecendo-se que "a qualidade da formação dos recursos humanos e o acesso ao conhecimento fazem da educação uma ferramenta especial para a obtenção da equidade, da competitividade e para o desenvolvimento da cidadania". 387

Outro ponto de destaque do referido documento recai sobre a formulação de propostas de ação específicas para cada nível educacional, de modo que, pela primeira vez, a educação básica esteve efetivamente destacada dos outros níveis educacionais, gozando, assim, da propositura de metas e ações próprias.

Para a formulação destas, o SEM determinou dois blocos temáticos com o objetivo de norteá-las: (a) identificação do aprendizado como processo cultural integral, destacando-se a utilização de novas tecnologias para o ensino de História, Geografia, Línguas e Cultura, tendo como objetivo realçar a dimensão da integração regional; e (b) qualidade da educação para todos, com ênfase nos aprendizados e gestões participativos e contextualizados. ${ }^{388}$

Depreende-se da leitura das metas uma grande preocupação com a repetência e abandono escolar, sobretudo nos primeiros anos de escolaridade ${ }^{389}$, além do reforço à prioridade educativa para os grupos socialmente vulneráveis - definidos como aqueles compostos por meninos e meninas portadores de necessidades especiais de aprendizagem, em

\footnotetext{
387 Anexo II da Decisão CMC 15/01 - Plano Trienal do Setor Educativo do MERCOSUL 2001-2005, Introdução.

${ }^{388}$ Anexo II da Decisão CMC 15/01 - Plano Trienal do Setor Educativo do MERCOSUL 2001-2005, Plano de Ação. Define ainda o mencionado documento que "esta contextualização está ligada à flexibilidade e pertinência curricular, enquanto que a participação se vincula à autonomia dos atores na construção dos aprendizados".

${ }^{389}$ Esta preocupação já havia sido estampada no preâmbulo da ata da XX Reunião dos Ministros da Educação, em 28 de junho de 2001. Ver MERCOSUL/RME/Ata n. 01/01.
} 
situações de pobreza urbana e rural, grupos indígenas e outros setores em situação de marginalidade de social, cultural e econômica. ${ }^{390}$

Ademais, reconhece o documento a relevância da valorização da escola básica como loco privilegiado para a constituição de uma consciência cidadã favorável à integração regional, assim como a importância de uma maior articulação com as políticas educacionais nacionais para este nível de ensino. A seguir, apresentam-se as metas e ações do Plano para a Educação Básica durante o período:

\section{Q.28 - Plano de Ação: Área de Educação Básica ${ }^{391}$}

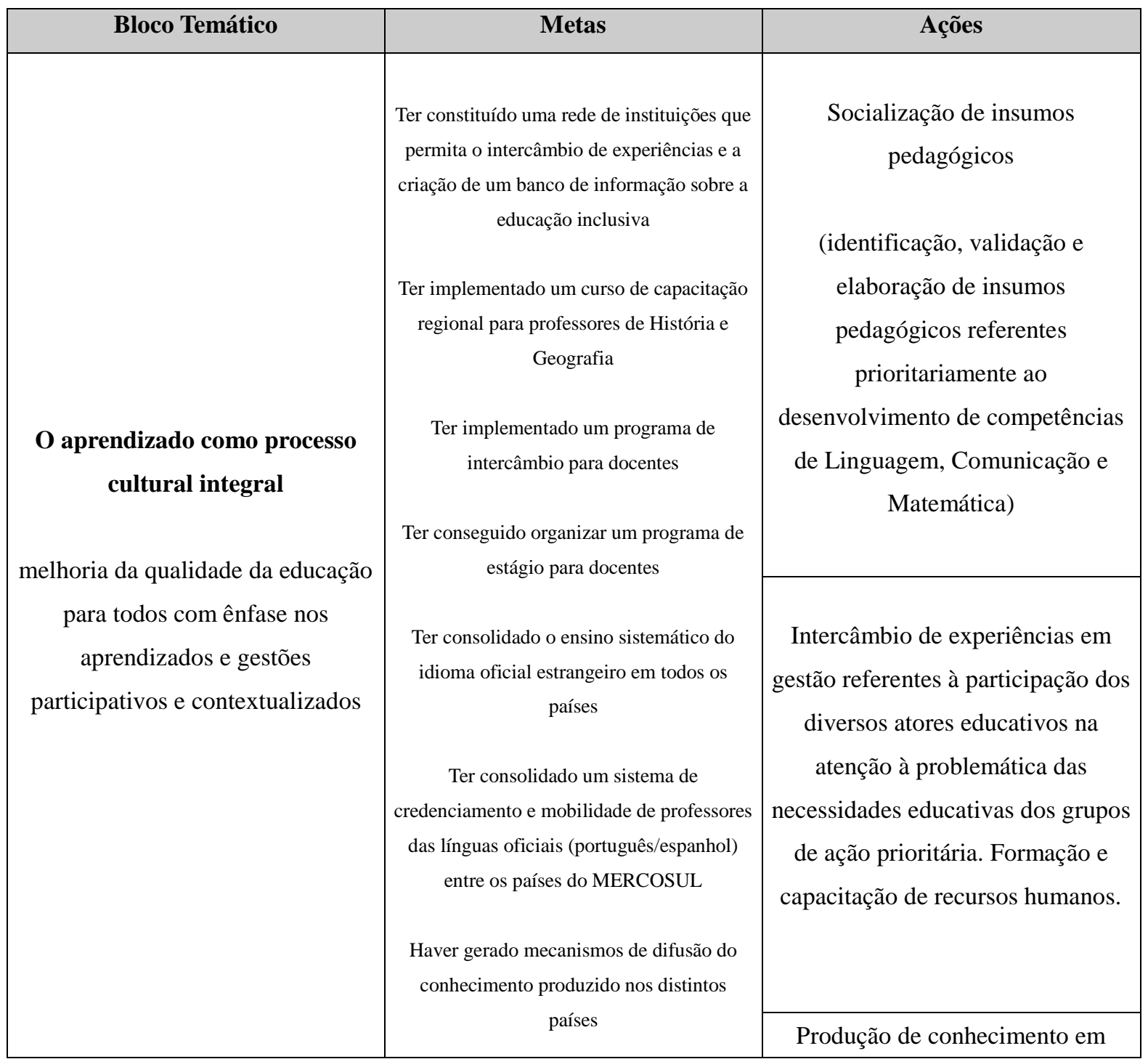

${ }^{390}$ Anexo II da Decisão CMC 15/01 - Plano Trienal do Setor Educativo do MERCOSUL 2001-2005, Plano de Ação.

${ }^{391}$ A versão em português se encontra disponível na página eletrônica do governo brasileiro dedicada ao MERCOSUL: $\quad$ http://www.MERCOSUL.gov.br/normativa/decisoes/2001/MERCOSUL-cmc-dec-nb0-1501/anexo. Último acesso em 23 de janeiro de 2010. 


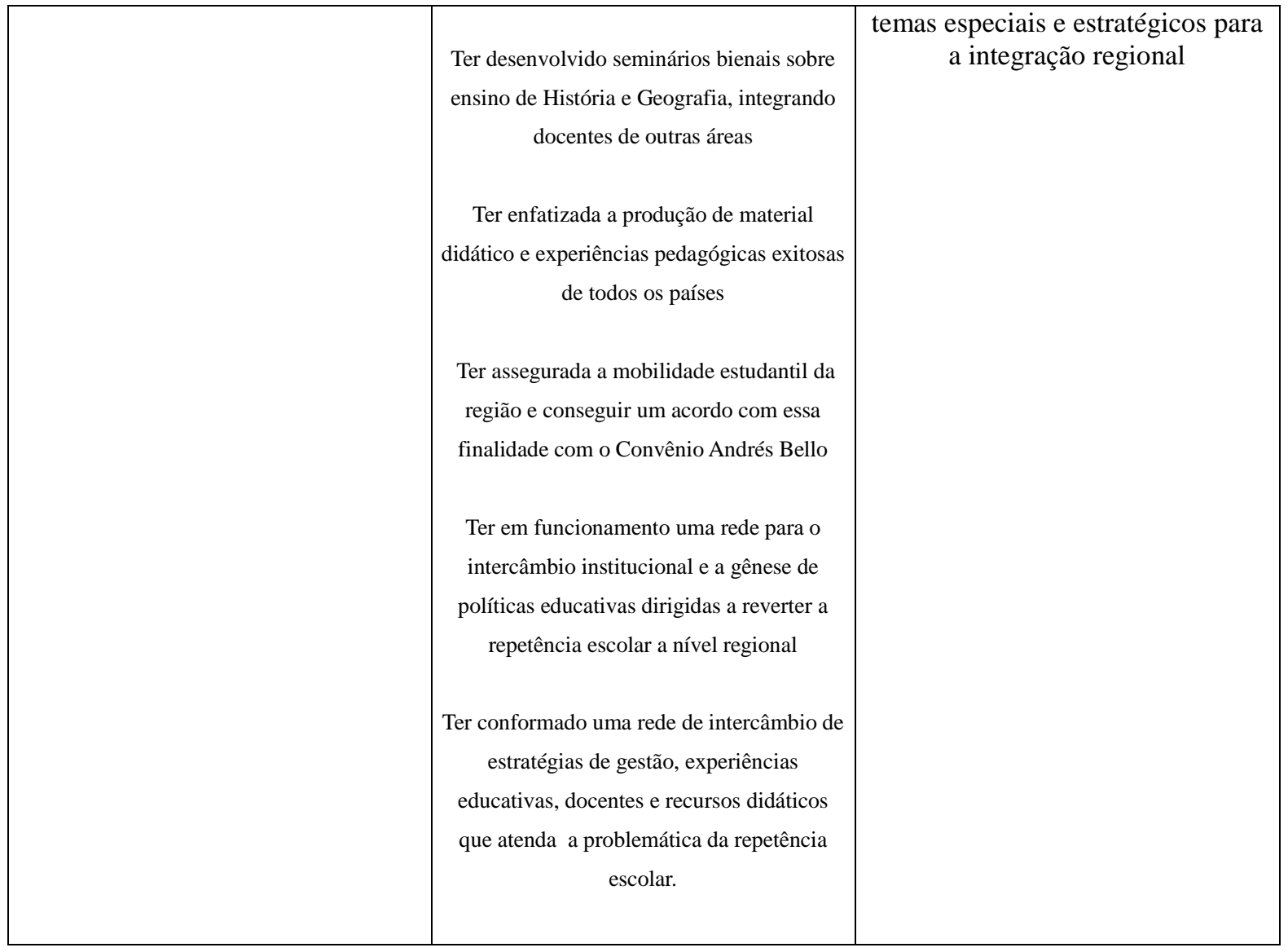

O período compreendido por este Plano, contudo, conheceu um volume significativamente menor de iniciativas protocolares, estas, sobretudo, voltadas a extensão da integração educativa nas diferentes etapas de ensino aos países associados ao bloco, os quais ainda não faziam parte dos protocolos assinados acerca da matéria. ${ }^{392}$

Neste intuito, por meio da Decisão CMC 26/02, datada de 06.12.2002, aprovou-se três protocolos referentes à integração educativa, com o objetivo de estender seus efeitos aos países associados ao bloco. São eles:

(a) Educação Básica:

- Protocolo de Integração Educativa e Reconhecimento de Certificados, Títulos e Estudos de Nível Fundamental e Médio Não-Técnico entre os Estados-Partes do MERCOSUL, a República da Bolívia e a República do Chile;

\footnotetext{
${ }^{392}$ Ainda podemos mencionar o "Acordo de Admissão de Títulos, Certificados e Diplomas para o Exercício da Docência no Ensino de Português e Espanhol como Línguas Estrangeiras nos Estados-Partes”, aprovado pela Decisão CMC 09/05, datada de 19.06.2005.
} 
(a)

Educação Superior:

Protocolo de Integração Educacional para a Formação de Recursos Humanos no Nível de Pós-Graduação entre os Estados-Partes do MERCOSUL e da República da Bolívia; e,

- $\quad$ Protocolo de Integração Educacional para o Prosseguimento de Estudos de Pós-Graduação nas Universidades dos Estados-Partes do MERCOSUL e da República da Bolívia.

Esta diminuição no número de iniciativas protocolares, ao nosso ver, não deve ser encarada como um arrefecimento do ímpeto ou ainda dos esforços em prol da promoção educacional na região. Ao contrário, trata-se de consequência natural, quando comparada à acelerada atividade empreendida pelo SEM ao longo de sua primeira década, assim como da prioritarização do desenvolvimento e acompanhamento dos projetos apresentados para o período. ${ }^{393}$ Dentre estes, podemos destacar para a educação básica:

“a) a edição, a partir de 2003, de um concurso histórico-literário, 'Caminhos do MERCOSUL', realizado a cada ano sob a responsabilidade de um dos países membros ou associados;

b) a implementação do projeto 'Bibliotecas Escolares do MERCOSUL', que envolve a seleção de cinco obras literárias de autores consagrados de cada país, num total de 30 títulos, destinados aos alunos da primeira à nona série/ano; e,

c) 'Escolas de Fronteiras', uma iniciativa de Brasil e Argentina de implementação de um projeto para a educação intercultural, baseada no ensino do português e do espanhol nas escolas públicas do ensino fundamental em cidades da região de fronteira entre esses países". ${ }^{394}$

d) Quarto Plano Estratégico do SEM (2006-2010)

\footnotetext{
393 O Marco Referencial para a Definição do Plano Estratégico do Setor Educativo do MERCOSUL 2006-2010 reconhece dois momentos distintos de atuação do SEM: "Un primer momento estuvo centrado en la conformación orgánica del SEM, en la elaboración del primer plan de acción y en la firma de los acuerdos y protocolos que permitieron avanzar en los procesos de armonización de los sistemas educativos. Un segundo momento estuvo pautado por la realización de proyectos en común. Este período estuvo signado sobre todo por proyectos en educación básica (Bibliotecas Escolares, Caminos del MERCOSUR, enseñanza del español y el portugués) y en Educación Superior (MARCA, MEXA).” (grifos originais).

394 ANASTASIA, Fatima et alli. op. cit. p. 59. Esclarece ainda este documento que o Projeto "Escolas de Fronteira", a partir de 2006, foi estendido a todos os demais países do SEM, por decisão aprovada na XXXI Reunião de Ministros do MERCOSUL.
} 
O presente Plano do Setor Educacional do MERCOSUL foi aprovado quando da realização da XXIX Reunião de Ministros de Educação dos Países do MERCOSUL, Bolívia, Chile e Venezuela, ocorrida no dia 10 de novembro de 2005, na cidade de Montevidéu. Tratase, portanto, da primeira vez que o Plano do SEM prescinde de aprovação do Conselho Mercado Comum, a qual somente deixou de ser necessária em virtude do reconhecimento da proeminência da RME na condução da política educacional regional, através da aprovação da estrutura orgânica do setor pela Decisão CMC 15/01 - Anexo I. Ainda por ocasião da referida reunião, definiu-se que o CCR ficaria encarregado em formular programas, metas e ações que refletissem os anseios expostos no documento, as quais foram elaboradas e incorporadas ao Plano na RME seguinte. ${ }^{395}$

Este Plano destoa dos anteriores pela adoção de uma postura política extremamente crítica, sobretudo em sua introdução, a qual destaca a deterioração do cenário político internacional. Entende que este resultado advém, em parte, das limitações das ações e resultados dos organismos internacionais, especialmente quando acionados a promover a paz e o desenvolvimento econômico-social na região, onde os indicadores de pobreza teimam em permanecer alarmantes. Este cenário de descrença institucional, segundo os redatores do documento, "tem levado a alguns Estados mais desenvolvidos a impulsionar políticas globais, vinculando-as a organismos como o Banco Mundial e a Organização Mundial do Comércio".396

Essa crítica, contudo, contrasta fortemente com a visão que permeou a elaboração do Marco Referencial para a Definição do Plano Estratégico do Setor Educacional do MERCOSUL, ${ }^{397}$ documento este que apresenta um balanço das atividades desempenhadas sob o plano estratégico anterior, bem como aponta as principais preocupações políticoeducativas para o bloco regional.

Em seu texto, o Marco Referencial apresenta um tom marcado pelo realismo da situação precária da educação nos países do MERCOSUL ${ }^{398}$, cotejado, porém com o

\footnotetext{
${ }^{395}$ Ver MERCOSUL/RME/Ata n. 01/06.

${ }^{396}$ Plano do Setor Educativo do MERCOSUL 2006-2010, p.5.

${ }^{397}$ Documento elaborado e apresentado no Taller de Reflexión Sobre el Plan Estratégico del Sector Educativo del Mercosur, ocorrido entre os dias 21 e 24 de setembro de 2005, na cidade de Valle Hermoso, Córdoba, Argentina.

${ }^{398}$ Neste documento podemos ler: "Existe plena conciencia en nuestros países respecto del papel central que la educación cumple un en los procesos de desarrollo con justicia e inclusión social. Sin embargo, y a pesar de los
} 
reconhecimento da relevância da educação no plano internacional e regional, sobretudo por meio da articulação de políticas fomentadas em âmbito global, sob os auspícios das Nações Unidas. Neste sentido, reconhece-se que

\begin{abstract}
"La educación fortaleció su presencia en la agenda internacional de los países, múltiples espacios internacionales plantean la necesidad de apostar por la educación como forma de combate a los peores flagelos del siglo XXI. Los Objetivos de Milenio y los esfuerzos de Educación para todos, formulados en el marco del sistema de Naciones Unidas, proporciona un buen encuadre, si bien de carácter universal, para los esfuerzos que viene realizando nuestros países para aumentar la equidad y calidad de nuestros sistemas. Los Ministerios de la Región han expresado también en forma permanente su apoyo en el ámbito de la Organización de Estados Iberoamericanos al Pacto por la Educación, que permitirá movilizar recursos a favor de esos grandes propósitos".
\end{abstract}

Outro ponto de relevo, presente em ambos os textos, dá conta de uma mudança significativa de perspectiva quanto aos objetivos almejados pelas políticas educacionais do bloco, visto que o documento é claro ao afirmar que "el mayor desafío de nuestras naciones no está dirigido sólo a incorporar más niños, niñas, adolescentes y jóvenes al sistema educativo, sino a darles una educación de calidad y pertinencia a la realidad en la que viven" 399 .

Assim, embora haja o reconhecimento da importância da intensificação de medidas vinculadas à universalização, a ênfase no documento recai, agora, sobre a questão da qualidade na prestação educacional, bem como a garantia de aderência entre o ensino ministrado em sala de aula e a realidade vivenciada pelos educandos. ${ }^{400}$

avances cuantitativos producidos en estos años, las realidades de nuestros sistemas educativos no son las mejores para cumplir este papel. Esta situación se puede sintetizar en la gran inequidad para acceder al conocimiento y al impacto que ha recibido la educación debido al proceso de fragmentación que han vivido nuestras sociedades". Este parágrafo foi mantido em sua integralidade na introdução do Plano Estratégico do SEM 2006-2010.

${ }^{399}$ Plano Estratégico do Setor Educativo do MERCOSUL 2006-2010, p.6.

${ }^{400}$ A relação dos conteúdos ministrados em sala de aula e a realidade dos alunos está imbuída também da preocupação com uma preparação eficiente para o mercado de trabalho, como aponta o documento: "La vinculación de la educación con el mundo productivo y especialmente la formación profesional, también se las considera fundamental, ante el cambio de los paradigmas de desarrollo que comienzan a vislumbrarse en la Región, caracterizadas por improntas de tipo industrialistas, que las diferencia de las llevadas a cabo en la década de los 90. Frente a esto algunos países han empezado a recuperar la educación técnica como herramienta del desarrollo". A redação apresentada pela introdução do Plano Estratégico do SEM 2006-2010 foi alterada para: "Se considera fundamental la vinculación del mundo productivo con la educación y especialmente con la formación profesional, más aún con los cambios que comienzan a vislumbrarse en la región. Frente a esto los países han empezado a recuperar la educación técnica como herramienta del desarrollo". 
Como sói fazer, o SEM introduz neste documento novas definições de visão e missão, apresentados a seguir:

\section{Q. 29 - Linhas Gerais do Plano do SEM 2006-2010 ${ }^{401}$}

\begin{tabular}{|c|c|c|}
\hline Visão & Missão & Objetivos Estratégicos \\
\hline $\begin{array}{l}\text { Ser un espacio regional donde se } \\
\text { brinda y garantiza una educación con } \\
\text { equidad y calidad, caracterizado por el } \\
\text { conocimiento recíproco, la } \\
\text { interculturalidad, el respeto a la } \\
\text { diversidad, la cooperación solidaria, } \\
\text { con valores compartidos que } \\
\text { contribuyen al mejoramiento y } \\
\text { democratización de los sistemas } \\
\text { educativos de la región y a generar } \\
\text { condiciones favorables para la paz, } \\
\text { mediante el desarrollo social, } \\
\text { económico y humano sustentable. }\end{array}$ & $\begin{array}{c}\text { Conformar un espacio educativo } \\
\text { común, a través de la concertación de } \\
\text { políticas que articulen la educación con } \\
\text { el proceso de integración del } \\
\text { MERCOSUR, estimulando la } \\
\text { movilidad, el intercambio y la } \\
\text { formación de una identidad y } \\
\text { ciudadanía regional, con el objeto de } \\
\text { lograr una educación de calidad para } \\
\text { todos, con atención especial a los } \\
\text { sectores más vulnerables en un proceso } \\
\text { de desarrollo con justicia social y } \\
\text { respeto a la diversidad cultural de los } \\
\text { pueblos de la región. }\end{array}$ & $\begin{array}{l}\text { 1) Contribuir a la integración regional } \\
\text { acordando y ejecutando políticas } \\
\text { educativas que promuevan una } \\
\text { ciudadanía regional, una cultura de paz } \\
\text { y el respeto a la democracia, a los } \\
\text { derechos humanos y al medio } \\
\text { ambiente; 2) Promover la educación de } \\
\text { calidad para todos como factor de } \\
\text { inclusión social, de desarrollo humano } \\
\text { y productivo; 3) Promover la } \\
\text { cooperación solidaria y el intercambio, } \\
\text { para el mejoramiento de los sistemas } \\
\text { educativos; 4) Impulsar y fortalecer } \\
\text { programas de movilidad de estudiantes, } \\
\text { pasantes, docentes, investigadores, } \\
\text { gestores, directivos y profesionales; e } \\
\text { 5) Concertar políticas que articulen la } \\
\text { educación con el proceso de } \\
\text { integración del MERCOSUR. }\end{array}$ \\
\hline
\end{tabular}

Conforme nos informa Fátima Anastasia et alli, o atual plano também estabelece um conjunto de princípios orientadores das ações acordadas, de acordo com alguns preceitos tidos como basilares na atuação do SEM para o período:

“a) confiança: as ações devem ser voltadas para a redução das incertezas e para o fortalecimento dos vínculos intergovernamentais no interior do SEM;

b) respeito e consenso: princípios que devem orientar o respeito em relação aos processos e às políticas nacionais e o compromisso de se buscar acordos a partir desse marco;

c) solidariedade: apoio solidário aos países que, em circunstâncias específicas, não possam cumprir total ou parcialmente os projetos e atividades de interesse; e

d) cooperação: reconhecimento das simetrias entre os países e da importância da assistência técnica e da cooperação entre os sistemas educativos". 402

${ }^{401}$ Definições retiradas do Plano do Setor Educativo do MERCOSUL 2006-2010, pp. 9-10. Por se tratar do plano educativo em vigor, optamos pela manutenção da nomenclatura em espanhol apenas para podermos transmitir aos leitores o real intento dos formuladores do plano.

${ }^{402}$ ANASTASIA, Fatima et alli. op. cit. p. 62-63. 
É mister reconhecer que o Plano estabelece, em riqueza de detalhes, as metas, ações, prazos e resultados esperados em cada nível de ensino, dentro das linhas estratégicas adotadas. Assim, diferentemente dos planos iniciais, pode-se dizer que este plano preza pelo pragmatismo de suas ações, marcado pela descrição pormenorizada destas. Especificamente a respeito da educação básica, o Plano estabelece um vasto número de metas e resultados esperados, os quais estudaremos detidamente na próxima seção.

\section{$\underline{3.4 \text { - O Direito à Educação Básica no MERCOSUL }}$}

Nesta seção, apresentaremos os programas e projetos desenvolvidos especificamente para a promoção do direito à educação básica no bloco regional. Como condução do estudo, adotamos as cinco linhas estratégicas apresentadas no último Plano do Setor Educacional do MERCOSUL, visando ao período compreendido entre 2006 e 2010, cotejando-as com as ações empreendidas pela Comissão Regional Coordenadora de Educação Básica (CRC-EB) no âmbito de cada linha. Contudo, apresentaremos apenas três, visto que duas linhas estratégicas não possuem nenhuma referência à educação básica. ${ }^{403}$ São eles:

\begin{tabular}{|c|c|}
\hline \multicolumn{2}{|c|}{$\begin{array}{l}\text { 1) "Contribuir a la integración regional acordando y ejecutando políticas educativas } \\
\text { que promuevan una ciudadanía regional, una cultura de paz y el respeto a la } \\
\text { democracia, a los derechos humanos y al medio ambiente" } 404\end{array}$} \\
\hline $\begin{array}{l}\text { Resultados } \\
\text { Esperados }\end{array}$ & $\begin{array}{l}\text { Difusão da temática da identidade regional por meio da elaboração de } \\
\text { material didático, capacitação docente e incentivo à leitura de autores da } \\
\text { região; Preparo para o ensino do português e espanhol como segunda língua }\end{array}$ \\
\hline
\end{tabular}

O Setor Educacional do MERCOSUL tem atuado de forma intensa nesta linha estratégica, onde se percebe uma concentração das ações desenvolvidas pelo setor durante os últimos anos. Para alcançar os resultados esperados, criaram-se uma série de programas visando a difundir o conhecimento sobre as diversas culturas existentes no bloco regional, como forma de contribuir ao processo de integração. Podemos, a princípio, dividir estas ações

\footnotetext{
403 São elas: “3) Promover la cooperación solidaria y el intercambio, para el mejoramiento de los sistemas educativos; e 5) Concertar políticas que articulen la educación con el proceso de integración del MERCOSUL". ${ }^{404}$ Por se tratar do plano educativo em vigor, optamos pela manutenção da nomenclatura em espanhol apenas para podermos transmitir aos leitores o real intento dos formuladores do plano.
} 
em três eixos: (a) confecção de materiais didáticos; (b) promoção da literatura regional; e (c) ensino de português e espanhol como segunda língua.

Desde sua gênese, o SEM expressa sua preocupação com um ensino que contemple a formação de uma consciência cidadã favorável aos ideais de integração. Neste sentido, identificou-se como área sensível e prioritária a introdução de elementos comuns nos materiais didáticos do ensino curricular de História e Geografia, de forma a estimular a consolidação da integração educacional. ${ }^{405}$

Para que houvesse uma efetiva troca de idéias e experiências sobre os conteúdos e práticas educativas a serem adotadas, definiu-se a realização dos "Seminários Bienais sobre o Ensino de História e Geografia". ${ }^{406}$ Usualmente estes encontros são abertos aos docentes e autores de textos escolares, bem como aos representantes dos governos e de universidades formadoras de professores destas matérias.

Outra ação que versa sobre a confecção de materiais didáticos diz respeito à promoção dos direitos humanos na educação mercosulina. A partir da elaboração de critérios comuns, definidos em meio a reuniões para este fim, prevê-se a elaboração, sob responsabilidade argentina, de materiais didáticos que fortaleçam a formação cidadã e democrática.

Com relação às ações de promoção da literatura regional, destacamos o Projeto "Caminhos do MERCOSUL", em andamento desde 2003, que trata da realização de um concurso histórico-literário anual, voltado aos jovens de 16 e 17 anos da região. O principal objetivo é o de fortalecer a identidade mercosulina por meio de uma aproximação dos jovens com os diferentes aspectos culturais e históricos da região. A cada ano, um dos Estados participantes do SEM é responsável por coordenar suas atividades, ficando encarregado de definir o mote a ser dissertado. Tradicionalmente o início do concurso ocorre no dia 26 de março, reforçando nas escolas a comemoração do aniversário do bloco regional. Ao total,

\footnotetext{
${ }^{405}$ Ex-ministro brasileiro da Educação, Carlos A. Chiarelli é polêmico ao considerar que apenas são integráveis os países que comungam de uma história em comum, além de uma vizinhança física real. Nestes termos, acredita que o MERCOSUL, em virtude da história e geografia do sub-continente, possui uma "genética sóciopolítico-cultural" própria, a qual "nos permite e recomenda a verdadeira integração", CHIARELLI, Carlos A. op.cit. p. 17.

${ }^{406}$ Até o presente momento foram realizados os seguintes encontros: Brasil (1997), Uruguai (1999), Argentina (2002) e Chile (2004).
} 
cada país seleciona seis ganhadores, os quais participarão de uma viagem de estudos de 10 dias em alguma localidade emblemática da região.

O Projeto "Bibliotecas Escolares", por sua vez, consiste na iniciativa de incluir obras literárias de autores mercosulinos nos acervos escolares, de modo a promover o conhecimento da literatura regional, favorecendo, inclusive, a identificação de valores culturais comuns. A partir desta iniciativa do Ministério de Educação, Ciência e Tecnologia da Argentina, criou-se uma coleção composta de cinco títulos de cada país-membro do bloco, destinada aos estudantes entre o primeiro e o nono ano. Ademais, incentiva este projeto a utilização destas obras como recursos pedagógicos em sala de aula.

Dentro desta mesma perspectiva de aproximação cultural pela literatura, destaca-se outro projeto do SEM, intitulado "MERCOSUL Lê", o qual também veio a lume por iniciativa argentina. A proposta conforma a identificação de três obras de cada país integrante do setor, sendo que uma é voltada para crianças, outra para adolescentes e a última para adultos. Sob os auspícios do governo argentino, foram editados mais de um milhão e duzentos mil de exemplares, destinados sobretudo às escolas de fronteira e escolas em necessidades.

Entretanto, uma aproximação cultural definitiva não pode prescindir de uma comunicação efetiva entre os interlocutores. Pensando nisto, o incentivo ao aprendizado de português e espanhol enquanto línguas estrangeiras foi constante nos documentos e atas do SEM. ${ }^{407}$ Neste campo, mencionam-se a experiência das "Escolas de Fronteira" e o ensino obrigatório do português e espanhol no currículo obrigatório da do ensino fundamental voltado para alunos de escolas públicas localizadas na região de fronteira do Brasil e dos países do MERCOSUL. ${ }^{408}$

\footnotetext{
407 Cumpre mencionar que, por força da Decisão CMC 35/06, o guaraní é considerado idioma oficial do MERCOSUL. Entretanto, não há nenhum projeto em andamento para a promoção de seu ensino nos paísesmembros do bloco.

408 Segundo dados colhidos na página eletrônica do MERCOSUL Educacional, "Em 2006, aproximadamente quatro mil alunos estão envolvidos no Projeto, dos quais cerca de $15 \%$ têm aulas semanais em espanhol com os professores argentinos. Entre os 230 professores de cada país das cinco escolas participantes, 21 cruzam a fronteira para trabalhar com os alunos, uma ou duas vezes na semana.A metodologia utilizada tem como base o bilingüismo construído a partir da disponibilização de quadros docentes, formados em ambos os países. Desse modo, os professores dos países parceiros atuam nas escolas brasileiras e os professores brasileiros, nas escolas argentinas. Com isso, a unidade básica do projeto será o par de escolas-espelho/gêmeas, que atuam juntas formando uma unidade operacional. Esta forma permite aos docentes dos países envolvidos vivenciarem, nas suas formações, o bilingüismo que querem construir com os alunos”. Disponível em:
} 
As ações, porém, não se voltaram apenas para os educandos. Preocupado com o desenvolvimento de recursos humanos capacitados, o SEM realizou seminários que favorecessem, entre educadores, o intercâmbio de experiências e metodologias no ensino de línguas estrangeiras, priorizando aquelas que possuíssem aderência à realidade regional.

\begin{tabular}{|c|c|}
\hline $\begin{array}{l}\text { 2) "Promover } \\
\text { desarrollo hu }\end{array}$ & $\begin{array}{l}\text { ducación de calidad para todos como factor de inclusión social, de } \\
\text { o y productivo" }\end{array}$ \\
\hline $\begin{array}{l}\text { Resultados } \\
\text { Esperados }\end{array}$ & $\begin{array}{l}\text { Intercâmbio de experiências, materiais e práticas que favoreçam a inclusão } \\
\text { social e diversidade étnica na educação inicial, especial, rural e de jovens e } \\
\text { adultos; }\end{array}$ \\
\hline
\end{tabular}

Todos os diplomas legais que tratam dos sistemas educacionais nacionais da região apresentam acentuada deferência a uma educação de qualidade como fator de inclusão social. Para atender a estes propósitos, o SEM desenvolve dois projetos temáticos voltados para a educação ministrada nos países do bloco regional: "Educar com Equidade" e "Educar na Diversidade", ambos voltados para o intercâmbio de experiências e práticas que favoreçam a inclusão social e diversidade étnica. Ademais, foi concedida especial atenção à educação inicial e às modalidades especial, rural e de jovens e adultos, em função do perfil dos educandos.

O projeto "Educar com Equidade" nasce com o propósito de mitigar a iniqüidade no acesso e garantia do direito à educação na região mercosulina, promovendo reflexões acerca de políticas compensatórias e estratégias inovadoras para aumentar a cobertura e retenção do sistema escolar. Assim, este projeto está imbuído da vontade de estabelecer um verdadeiro acesso irrestrito e com qualidade ao conhecimento e aprendizagem, voltando-se em especial aos setores mais desfavorecidos das sociedades mercosulinas. As áreas tidas como prioritárias para o projeto são: retenção escolar, repetência, sobre-idade, deserção, reinserção, melhoria da qualidade da aprendizagem e melhoria da qualidade de vida dos alunos.

http://www.sic.inep.gov.br/index.php?Itemid=28\&id=72\&option=com_content\&task=view. Acesso em $23 \mathrm{de}$ janeiro de 2010. 
As dificuldades enfrentadas pelos docentes no atendimento às diversidades educacionais inspiraram a criação do projeto "Educar na Diversidade". No âmbito deste projeto, são selecionadas cinco escolas em cada país, representando diferentes realidades geográficas, culturais e socioeconômicas.

4) "Impulsar y fortalecer los programas de movilidad de estudiantes, pasantes, docentes, investigadores, gestores, directivos y profesionales".

Resultados

Elaboração de tabelas de equivalências de estudos em nível primário Esperados ampliadas aos países do $\mathrm{CAB}$ e não pertencentes à região; Tabela de equivalência em nível médio técnico atualizada; Intercâmbio e estágios para supervisores, diretores e docentes dos centros educativos

Conforme já demonstramos anteriormente, o processo de redemocratização do subcontinente acelerou não apenas o ímpeto de integração regional, como também foi responsável por introduzir uma série de mudanças significativas no desenho dos sistemas educacionais nacionais. Neste contexto de reestruturação, a despeito dos grandes avanços obtidos no sentido de incentivar e fortalecer programas de mobilidade na educação superior, não se pode olvidar que a educação básica também foi campo de importantes conquistas para a mobilidade de alunos, docentes e diretores.

As atividades inseridas nesta linha estratégica remontam ao ano de 1995, quando da assinatura do "Protocolo de Integração Educativa para o Reconhecimento de Certificados, Títulos e Estudos de Nível Primário e Médio Não-Técnico". Ressalte-se que este protocolo foi ratificado por todos os países-membros do bloco e atualmente consta de lista de documentos mercosulinos tidos como prioritários em caso de associação ao bloco regional.

Os trabalhos desenvolvidos dentro desta linha temática foram coordenados por um Comitê Regional Técnico, posteriormente incorporado pela Comissão Regional Coordenadora de Educação Básica (CRC-EB), a qual ficou encarregada de promover a efetiva implementação do protocolo, assim como promover a atualização dos requisitos e condições da tabela de equivalências, quando necessário. Em virtude das sucessivas mudanças estruturais dos sistemas educacionais nacionais, a tabela sofreu diversas alterações, sendo que a regra atual de sua interpretação, aprovada pela Decisão CMC 06/06, é a seguinte: 
Interpretação das Tabelas de Equivalência ${ }^{409}$ :

Até que se complete a transição para o ensino fundamental de 9 anos no Brasil (2010), os alunos que se transladem dos Estados Partes e associados do MERCOSUL aos sistemas educacionais do Brasil que ainda apliquem um ensino fundamental de 8 anos, ao completarem o $8^{\circ}$ (oitavo) ou $9^{\circ}$ (nono) ano de escolaridade básica - ou suas denominações equivalentes, terão direito a uma avaliação diagnóstica pela instituição educativa receptora para sua matrícula respectivamente no $1^{\circ}$ (primeiro) ou $2^{\circ}$ (segundo) ano de educação média não técnica do Brasil. Em todos os casos, preservar-se-ão os requisitos mínimos estabelecidos na tabela de equivalência.

${ }^{409}$ Cumpre mencionar que a tabela de equivalências se encontra anexa à essa dissertação. 


\section{CONSIDERA ÇOES FINAIS}

Longe de pretender realizar conclusões terminativas da pesquisa, aproveitamos este espaço para discorrermos com maior liberdade acerca dos resultados auferidos ao longo do presente estudo.

A proteção ao direito à educação básica advém de um longo processo histórico, consubstanciado nos fenômenos da constitucionalização dos ditos direitos fundamentais e na universalização dos direitos entendidos como humanos. Posto que haja uma unicidade doutrinária entre essas duas facetas do direito educacional, decorre daí, a existência dos dois planos normativos aqui estudados. Buscando compreender a verdadeira proteção normativa do direito à educação básica, o nosso trabalho se preocupou com a articulação entre a ordem normativa internacional e nacional, entendendo prevalecer, no caso do direito à educação básica, a norma que seja mais favorável ao tutelado.

Como demonstrou nosso estudo, as normas internacionais do direito educacional estão, regra geral, aquém daquelas presentes no plano constitucional dos Estados considerados neste estudo, o que denota o grau elevado de proteção presente nesses países. A preocupação com a gratuidade e obrigatoriedade da educação básica, temas prioritários no plano internacional, conhecem uma excelente proteção jurídica no plano interno, conferida por modificações legislativas recentes. Frise-se que as omissões constitucionais encontram guarida no plano infraconstitucional, o que confere uma proteção jurídica de qualidade inferior, porém ainda relevante.

Contudo, não se trata de minimizar ou desprezar o ordenamento internacional. A dupla proteção jurídica reveste de maior eficácia a proteção do direito à educação básica, ensejando eventual responsabilização internacional do Estado em caso de descumprimento no plano interno. Neste sentido, felicitamos a atual tendência de se conceder deferências constitucionais aos tratados de direitos humanos em geral, fato que produziu importante modificação no status do direito à educação no direito argentino, por exemplo. Contrastando com as parcas previsões educacionais no texto constitucional, os tratados internacionais recepcionados com hierarquia equivalente à norma constitucional neste ordenamento nacional revolucionaram a proteção do direito à educação básica. 
Persegue-se agora a efetividade destes direitos, sobretudo em países com baixo nível de desenvolvimento econômico, onde a reserva do possível "impossibilita" sobremaneira a plena realização dos direitos sociais. Contudo, este ponto escapa ao escopo do presente trabalho, dando azo a um eventual aprofundamento desta pesquisa.

Sem pretendermos a discorrer acerca de política educacional ou ainda sobre a eficácia das normas sociais perante os tribunais nacionais, objetos de estudo estranhos a essa dissertação, reconhecemos a tarefa hercúlea de garantia do direito à educação básica em sociedades aviltadas por acentuadas desigualdades sócio-econômicas. É forçoso reconhecer, no entanto, que os avanços auferidos ainda são muito tímidos, porém constantes. A guisa de exemplo, veja-se abaixo o ritmo da diminuição das taxas de analfabetismo entre os países mercosulinos estudados ${ }^{410}$ :

\section{Taxas de Analfabetismo nos Países do Mercosul}

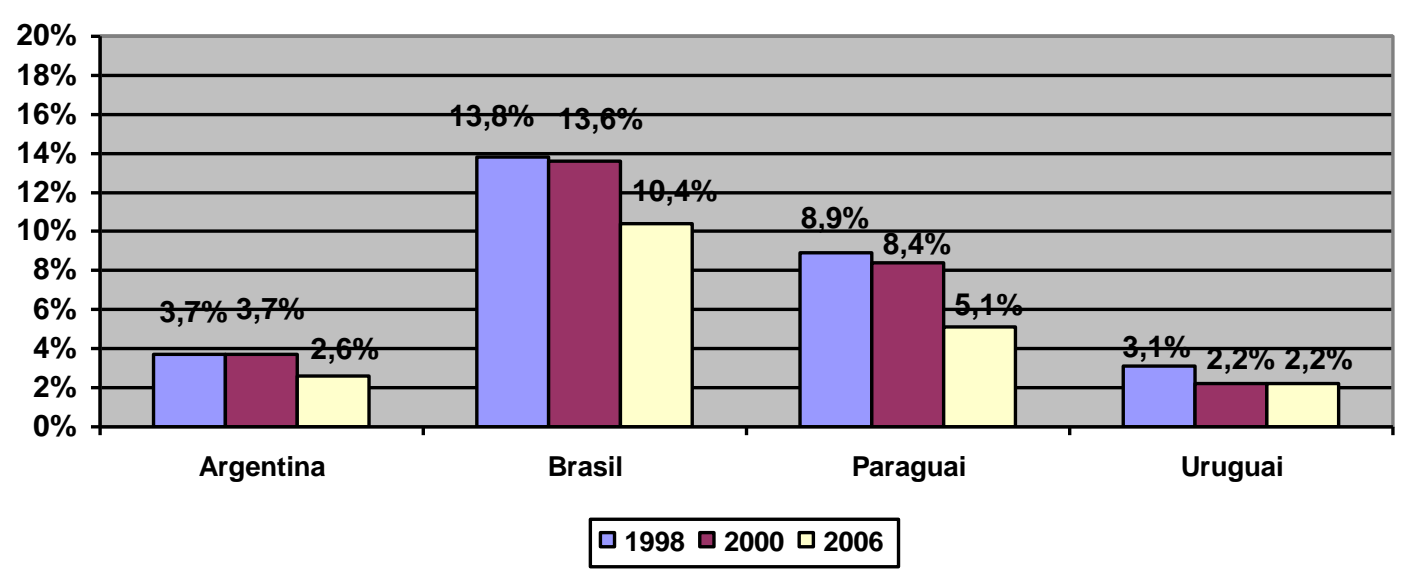

Esses números, contudo, podem esconder outra articulação positiva entre os planos nacionais e internacionais. Se cotejado aos ordenamentos nacionais o plano internacional

\footnotetext{
${ }^{410}$ Dados retirados de: MERCOSUL. Sistema de Informação e Comunicação do MERCOSUL EDUCATIVO. Vitrina Estadística 1998. Montevideú, 1998; MERCOSUL. Sistema de Informação e Comunicação do MERCOSUL EDUCATIVO. Vitrina Estadística 2000. Montevideú, 2000; MERCOSUL. Sistema de Informação e Comunicação do MERCOSUL EDUCATIVO. Vitrina Estadística 2006. Montevideú, 2006. Todos disponíveis em:

http://www.sic.inep.gov.br/index.php?option=com_docman\&task=cat_view\&gid=98\&Itemid=32. Acesso em 23 de janeiro de 2010.
} 
pouco inova na temática educacional, sua grande contribuição decorre de outro ponto merecedor de destaque: a ousadia dos documentos internacionais mais recentes, como a Declaração Mundial sobre Educação para Todos, firmada em Jomtien, na Tailândia, e repetida em diversos documentos internacionais posteriores.

Estes documentos internacionais estabelecem metas objetivas e quantificáveis a serem perseguidas pelos Estados, além de instituir mecanismos de supervisão e acompanhamento de seu progresso. Dentre as mais ambiciosas, destacamos a busca pela universalização do acesso aos níveis de ensino Cine 01 e 02 . Se as metas serão alcançadas, não podemos dizer, porém é inegável que há um forte estímulo político no sentido de sua observância pelos Estados.

Neste ponto, não podemos esconder nossa decepção com a timidez das atividades desempenhadas pelo SEM na promoção do direito à educação básica. Pelo estudo empreendido da natureza de suas atividades, podemos categorizá-las de três sortes: (a) compilação de dados estatísticos; (b) proteção jurídica ao reconhecimento de diplomas e certificados de conclusão de grau entre Estados-Partes; e, (c) fomento de uma identidade e mentalidade pró-integração, levando-se em consideração os eventuais ganhos econômicos a serem recebidos pela maior capacitação laboral dos cidadãos do MERCOSUL.

Ora, não podemos concordar com a visão reducionista proposta por Ana Maria Castro, a qual advoga uma submissão real e concreta da educação aos desígnios econômicos, identificados como os verdadeiros objetivos colimados dentro do processo de integração:

\footnotetext{
"Los objetivos finales de una educación coordinada a nivel regional son, por un lado, garantizar una consciencia regional que otorgue respaldo humano al proceso y, a su vez, lograr el reconocimiento mutuo de los distintos estudios y si fuese posible, la consecución de curricula regionales (...) Pero, hilando más fino, la educación no puede ser vista como hecho aislado; hoy todos somos conscientes de su estrecha relación con las necesidades del sector productivo. ¿Para qué educamos? Pues para dotar a los individuos de una sociedad con los instrumentos que le permitan entender el mundo que les rodea y ganarse la vida, asegurar su futuro económico-laboral". ${ }^{411}$
}

Rogando perdão pela franqueza, parece-me que tal visão pressupõe, na verdade, a cooptação intelectual dos educandos do plano regional, no sentido de convencê-los, ou ainda, doutriná-los no sentido da promoção dos ideais econômicos da integração. A nosso ver, enquanto o plano internacional dedica-se a assegurar a realização dos conteúdos materiais do

${ }^{411}$ CASTRO, Ana María. op. cit. pp. 91-92. 
direito à educação, é com tristeza que reconhecemos que o plano regional tem se mostrado apenas preocupado em "ganhar dinheiro" pela capacitação intelectual de sua mão-de-obra nacional.

É inegável que um nível superior de educação franqueia o acesso a postos economicamente mais vantajosos, contudo, também promove um bem maior: a própria realização enquanto ser humano, visto que o direito à educação se apresenta como pressuposto necessário para a realização e usufruto dos demais direitos fundamentais. Recentemente Nina Ranieri (2009) demonstrou ainda a estreita ligação entre educação e cidadania, de tal sorte que a sua plena realização está condicionada a um prévio preparo obtido pela via educacional.

Tal fato pode ser explicitado com maior clareza se cotejarmos o papel da educação no contexto de integração do MERCOSUL com a sua defesa presente na integração européia, a qual, por meio da Carta de Direitos Fundamentais, proclamada em 2000, instituiu:

\begin{abstract}
Artigo 14
Direito à educação

1. Todas as pessoas têm direito à educação, bem como ao acesso à formação profissional e contínua;

2. Este direito inclui a possibilidade de frequentar gratuitamente o ensino obrigatório; e,

3. São respeitados, segundo as legislações nacionais que regem o respectivo exercício, a liberdade de criação de estabelecimentos de ensino, no respeito pelos princípios democráticos, e o direito dos pais de assegurarem a educação e o ensino dos filhos de acordo com as suas convicções religiosas, filosóficas e pedagógicas. ${ }^{412}$
\end{abstract}

Perceba-se que a União Européia não inova na defesa do direito à educação, repetindo as disposições internacionais (e certamente constitucionais, na maioria de seus membros). Contudo, assim o bloco europeu confere maior eficácia ao direito à educação básica, inclusive permitindo o acesso a Corte comunitária especializada.

Certamente haverá aqueles que argumentarão no sentido de que o MERCOSUL nasce imbuído de uma perspectiva meramente econômica, sem as pretensões de uma maior

\footnotetext{
${ }^{412}$ UNIÃO EUROPÉIA. Carta dos Direitos Fundamentais da União Européia. Nice, 2000. Disponível em: http://eur-lex.europa.eu/LexUriServ/LexUriServ.do?uri=CELEX:32000X1218(01):PT:HTML. Acesso em 23 de janeiro de 2010.
} 
aproximação política, nos moldes da qual assistimos no plano europeu. Conforme demonstramos na pesquisa, o mote inicial da integração mercosulina centrava-se, de fato, exclusivamente na esfera econômica, porém, com extrema rapidez ganhou novos contornos, de forma que o próprio SEM nasce em menos de um ano após a celebração do Tratado de Assunção.

Acreditamos, portanto, que diante das declarações internacionais e suas metas para a educação, o MERCOSUL tem sido mero espectador das atividades dos Estados. O direito à educação básica merece mais. 


\section{REFERENCIAS BIBLIOGRÁFICAS}

ABREU, Sergio. "El Mercosur a diez años de su creación". In: COMISSÃO PARLAMENTAR CONJUNTA DO MERCOSUL. Um País Chamado MERCOSUL. Brasília: Senado Federal, 2001, p. 49-58.

ABSI, Luis Alberto. Principios Generales de la Integración en el Derecho Positivo Argentino. Ajuris: Revista da Associação dos Juízes do Rio Grande do Sul, Porto Alegre, n. esp., p. 50-54, novembro, 1998.

ALFONSÍN, Raúl. “El Acta de Iguazu”. In: COMISSÃO PARLAMENTAR CONJUNTA DO MERCOSUL. Um País Chamado MERCOSUL. Brasília: Senado Federal, 2001, p. 27-38.

ALMEIDA, Marcos Neri de. O Direito à Educação Infantil e a Discricionariedade Administrativa. Dissertação (Mestrado em Relações Sociais) - Faculdade de Direito da Pontifícia Universidade Católica de São Paulo, São Paulo, maio, 2008.

ALVES, José Augusto Lindgren. Relações Internacionais e Temas Sociais - A Década das Conferências. Brasília: IBRI, 2001.

AMARAL, JUNIOR, Alberto do. Introdução ao Direito Internacional Público. São Paulo: Atlas, 2008.

ANASTASIA, Fátima et alli. "Redemocratização, Integração Regional e a Trajetória do Setor Educacional MERCOSUL". In: MERCOSUL. Estudo Analítico-Comparativo do MERCOSUL (2001-2005). Brasília: Inep, 2008, p. 37-76.

BARbOZA, Mário de Jesus. Política de Educação nos Planos do Setor Educacional do MERCOSUL - A Educação como Elemento de Integração e Desenvolvimento Regional. Dissertação (Mestrado em Educação) - Faculdade de Educação da Universidade do Oeste do Paraná - UNIOESTE, Cascavel, 2009 
BATTISTELLA, Dario. Theorie des Relations Internacionales. Paris: Presses de Sciences PO, 2004.

BERCOVICI, Gilberto. “As Possibilidades de uma Teoria do Estado". In: Revista da História das Idéias, Faculdade de Letras de Coimbra, vol. 26, 2005, p.7-32.

BERLIN, Isaiah. Four Essays on Liberty. Oxford: Oxford University, 1969.

BIEDERMANN, Soledad Villagra. "El Sistema Universal de Derechos Humanos". In: FELDMANN, Cynthia González (org.). El Paraguay frente al Sistema Internacional de los Derechos Humanos. Konrad Adenauer: Montevidéu, 2004, p. 141-157.

BOBBIO, Norberto. A Era dos Direitos (tradução de Carlos Nelson Coutinho). Rio de Janeiro: Campus, 1992.

CANÇADO TRINDADE, Antônio Augusto. A Incorporação das Normas Internacionais de Proteção dos Direitos Humanos no Direito Brasileiro. San Jose: IIDH, ACNUR, CIVC, CUE, 1996.

CANOTILHO, José Joaquim Gomes. Direito Constitucional e Teoria da Constituição. Lisboa: Almedina, 1999.

CARR, Edmund H. Vinte Anos de Crise 1919-1939 (trad. Luiz Alberto Figueiredo Machado). 2a ed. Brasília: Universidade de Brasília, 2000.

CARTOU, Louis. L'Union Européene - Traités de Paris, Rome, Maastricht. 2a ed. Paris: Dalloz, 1996.

CARVAlHO, José Murilo. Cidadania no Brasil - o Longo Caminho. Rio de Janeiro: Civilização Brasileira, 2002.

CASELLA, Paulo Borba. MERCOSUL - exigências e perspectivas. São Paulo:LTr, 1996. 
CASSESE, Antonio. "Modern Constitutions and International Law". In: Recueil des Cours de l'Académie de Droit International de la Haye, 1985 III, tomo 192, Dordrecht: Martinus Nijhoff Publishers, 1986.

CASTRO, Amílcar de. Direito Internacional Privado. vol. I. $3^{\text {a }}$ ed. Rio de Janeiro: Forense, 1977.

CASTRO. Ana Maria. "Estado Del Arte de la Negociación en Educación”. In: CHIARELLI, Carlos Alberto; SIENRA, Jorge (org.). La Educación en un Proceso de Integración: el caso del Mercosur. São Paulo: LTr: ARCAM: Comisec, 2001.

CHIARELLI, Carlos Alberto. "Educação: Início e Fim da Integração". In: CHIARELLI, Carlos Alberto; SIENRA, Jorge (org.). La Educación en un Proceso de Integración: el caso del Mercosur. São Paulo: LTr: ARCAM: Comisec, 2001.

CONSTENLA, Carlos R. “Aplicación del derecho internacional de los derechos humanos por los tribunales de la República Argentina”. In: Revista IIDH, San Jose, n. 38, p. 111-152, jul$\operatorname{dez} 2003$.

DALlARI, Dalmo de Abreu. Elementos de Teoria Geral do Estado. 22a ed. São Paulo: Saraiva, 2001.

DALlARI, Pedro B. A. Constituições e os Tratados Internacionais. São Paulo: Saraiva, 2003.

FARIA, Werter R. "Os Processos Latino-Americanos de Integração". In: CASELLA, Paulo Borba (coord.). MERCOSUL: Integração Regional e Globalização. Rio de Janeiro: Renovar, 2000.

FELAMINGO, Fabrício. A Hierarquia dos Tratados Internacionais de Direitos Humanos - uma análise a partir da Emenda Constitucional 45/2004. Dissertação (Mestrado em Direito das Relações Econômicas Internacionais) - Faculdade de Direito da Pontifícia Universidade Católica, São Paulo, 2008. 
FELDMANN, Cynthia González. "La implementación de los tratados internacionales de derechos humanos por el Paraguay”. In: FELDMANN, Cynthia González (org.). El Paraguay frente al Sistema Internacional de los Derechos Humanos. Konrad Adenauer: Montevidéu, 2004.

FERRAJOLI, Luigi. A Soberania no Mundo Moderno. São Paulo: Martins Fontes, 2002.

FERREIRA FILHO, Manuel Gonçalves. Curso de Direito Constitucional. 27a ed. Saraiva: São Paulo, 2001.

FLORENCIO, Sérgio A. L.; ARAÚJO, Ernesto H. F. MERCOSUL Hoje. São Paulo: Alfa Omega, 1995.

FREITAS JUNIOR, Antônio R. "Os Direitos Sociais como Direitos Humanos num Cenário de Globalização Econômica e de Integração Regional”. In: PIOVESAN, Flávia (coord.). Direitos Humanos, Globalização Econômica e Integração Regional - Desafios de Direito Constitucional Internacional. São Paulo: Max Limonad, 2002.

FULQUET, Gastón A. El Proyecto Educativo para el Mercosur y los Debates en torno a la Internacionalización de la Educación Superior. Buenos Aires: CAEI, 2007.

GARCIA JUNIOR, Armando Alvares. Conflito Entre Normas do MERCOSUL e Direito Interno - Como resolver o problema? O caso brasileiro. São Paulo: LTr, 1997.

HELLER, Hermann. Teoria do Estado (trad. Lycurgo Gomes da Motta), São Paulo: Mestre Jou, 1968.

HUNTINGTON, Samuel. Terceira Onda de Democratização. São Paulo: Ática, 1994.

KELSEN, Hans. Teoria Geral do Direito e do Estado (trad. Luis Carlos Borges). Martins Fontes, São Paulo, 1992.

Teoria Pura do Direito (trad. João Baptista Machado). São Paulo: Martins Fontes, 2000. 
LAFER, Celso. A Reconstrução dos Direitos Humanos: um diálogo com o pensamento de Hannah Arendt. São Paulo: Companhia das Letras, 1988.

O Cenário Mundial e o Relacionamento União Européia/MERCOSUL. Revista de Política Externa, São Paulo, vol. 9., n.1. Ed. Paz e Terra, jun/ago. 2000.

A Internacionalização dos Direitos Humanos: constituição, racismo e relações internacionais. São Paulo. Manole, 2005.

LEWANDOWSKI, Enrique Ricardo. Globalização, Regionalização e Soberania. São Paulo: Juarez Oliveira, 2004.

LIMA, Maria Cristina de Brito Lima. A Educação como Direito Fundamental. Rio de Janeiro: Lumen Juris, 2003.

LIMA JUNIOR, Jayme Benvenuto. Os Direitos Humanos Econômicos, Sociais e Culturais. Rio de Janeiro: Renovar, 2001.

LIPSON, Leslie. Os Grandes Problemas da Ciência Política (tradução de Thomaz Newlands Neto). 2a. ed. Rio de Janeiro: Zahar, 1976.

LUÑO, Antonio Enrique Pérez. Derechos Humanos, Estado de Derecho y Constitución. Madrid: Tecnos, 1999.

MARSHALL, Thomas H. Cidadania, Classe Social e Status. Rio de Janeiro: Zahar, 1967.

MATEUCCI, Nicola; BOBBIO, Norberto; PASQUINO, Gianfranco. Dicionário de Política. v. 2. 7ª Ed., Brasília: Universidade de Brasília, 1995.

MELlO, Celso D. de Albuquerque. Curso de Direito Internacional Público. $1^{\text {o }}$ vol. $11^{\mathrm{a}}$ ed. Rio de Janeiro: Renovar, 1999. 
MONTECINO, Isidro C. C. “Acuerdo de Complementación Chile \& Mercosur". In: CASELLA, Paulo B. (coord.). MERCOSUL - Integração Regional e Globalização. Rio de Janeiro: Renovar, 2000.

OLIVEIRA, Romualdo P. “O Direito à Educação”. In: OLIVEIRA, Romualdo P.; ADRIÀO, Theresa (orgs.). Gestão, Financiamento e Direito à Educação. São Paulo: Xamã, 2001, p. 11-33.

PAGLIARINI, Alexandre. Constituição e Direito Internacional: cedências possíveis. Rio de Janeiro: Forense, 2004.

PAUPÉRIO, Arthur Machado. O Conceito Polêmico de Soberania. $2^{\mathrm{a}}$ ed. Rio de Janeiro: Forense, 1958.

PEROTTI, Alejandro Daniel. Habilitación Constitucional para la Integración Comunitaria - estudios sobre los Estados del Mercosur. t. II. Montevidéu: Konrad Adenauer, 2004.

PIOVESAN, Flávia. Direitos Humanos e o Direito Constitucional Internacional. São Paulo: Max Limonad, 2001.

- Globalização Econômica, Integração Regional e Direitos Humanos. In: PIOVESAN, Flávia (coord.). Direitos Humanos, Globalização Econômica e Integração Regional - Desafios de Direito Constitucional Internacional. São Paulo: Max Limonad, 2002.

Temas de Direitos Humanos. 2a ed. ampl. e at. São Paulo: Max Limonad, 2003.

. “Concepção Contemporânea de Direitos Humanos". In: HADDAD, Sérgio; GRACIANO, Mariângela (orgs.). A Educação entre os Direitos Humanos. São Paulo: Ação Educativa, 2006, p. 11-42. 
PRUJEL, María Elodia Almirón. "Los Derechos Humanos y la Constitución Nacional”. In: FELDMANN, Cynthia González (org.). El Paraguay frente al Sistema Internacional de los Derechos Humanos. Konrad Adenauer: Montevidéu, 2004. p. 27-40.

PUÑAL, Antonio Martínez; IGLESIAS, María Teresa Ponte. La Educación en el Proceso de Integración del Mercosur. Santiago de Compostela: Tórculo, 2001.

RAMOS, André de Carvalho. Os Direitos Humanos na Integração Econômica - análise comparativa da proteção de direitos humanos e conflitos jurisdicionais na União Européia e MERCOSUL. Tese (Livre Docência em Direito Internacional) - Faculdade de Direito da Universidade de São Paulo, São Paulo, 2005.

RANIERI, Nina Beatriz Stocco. Do Estado Liberal ao Estado Contemporâneo: notas sobre os processos de exaustão dos modelos políticos. Revista de Direito Constitucional e Internacional, São Paulo, v.9, n.36, p. 135-161, jul./set., 2001.

Um Conceito mais Amplo de Liberdade: Desenvolvimento, Segurança e Direitos Humanos para todos. Política Externa, São Paulo, v. 14, n. 2, p. 25-39, set./nov., 2005.

O Estado Democrático de Direito e O Sentido da Exigência de Preparo da Pessoa para o Exercício da Cidadania, pela Via da Educação. Tese (Livre Docência em Direito do Estado) - Faculdade de Direito da Universidade de São Paulo, São Paulo, 2009.

Educação Superior, Direito e Estado na Lei de Diretrizes e Bases (lei n. 9394/96). São Paulo: EDUSP/FAPESP, 2000.

RANIERI, Nina B. S.; ARNESEN, Erik S. O Supremo Tribunal Federal e o Direito Internacional À Educação: a Promoção Indireta dos Princípios e Normas Internacionais. In: AMARAL JÚNIOR, Alberto do; JUBILUT, Liliana Lyra. Jubilut, (orgs.). O STF e o Direito Internacional dos Direitos Humanos. São Paulo, Quartier Latin, 2009, p. 635 a 656. 
REZEK, Francisco. Direito Internacional Público (curso elementar). $7^{\mathrm{a}}$ ed. rev. Saraiva: São Paulo, 1998.

RIBEIRO, Patrícia Henriques. As Relações entre o Direito Internacional e o Direito Interno: Conflito entre o Ordenamento Brasileiro e Normas do MERCOSUL. Belo Horizonte: Del Rey, 2001.

SALGUEIRO, Jorge Silvero. La Constitución de la República del Paraguay de 20 de junio de 1992. In: Boletín Mexicano de Derecho Comparado, Cidade do México, v.31, n. 92, p. 503-535, mai./ ago., 1998.

SANTANA, Josefina Maria. "O MERCOSUL: A Educação e as Universidades". In: CASELLA, Paulo Borba (coord.). MERCOSUL: Integração Regional e Globalização. Rio de Janeiro: Renovar, 2000, p. 1019-1036.

SARLET, Ingo Wolfgang. A Eficácia dos Direitos Fundamentais. Porto Alegre: Livraria do Advogado, 1998.

SILVA, José Afonso da. Curso de Direito Constitucional Positivo. 10 a ed. São Paulo: Malheiros, 1995.

Direito Regional Econômico, Direitos Humanos e Direito Comunitário. In: PIOVESAN, Flávia (coord.). Direitos Humanos, Globalização Econômica e Integração Regional - Desafios de Direito Constitucional Internacional. São Paulo: Max Limonad, 2002.

SILVA, Roberta Soares da. "Artigos XXV e XXVI". In: BALERA, Wagner. Comentários à Declaração Universal dos Direitos do Homem. Brasília: Fortium, 2008, p. 133-146.

SOARES, Guido F. S. Curso de Direito Internacional Público. v.1.São Paulo: Atlas, 2002.

TAVARES, André Ramos. Curso de Direito Constitucional. 5a ed. São Paulo: Saraiva, 2007. 
TOMASEVSKI, Katarina. Human Rights Obligations: making education available, accessible, acceptable and adaptable. Gotemburgo: Novum Grafiska AB, 2001.

Free and Compulsory Education for All Children: the gap between promise and performance. Gotemburgo: Novum Grafiska AB, 2001.

Contenido y Vigencia del Derecho a la Educación. Revista IIDH: Instituto Interamericano de Derechos Humanos, San José, n. 36, p. 15-38, jul./dez., 2002.

- Indicadores del Derecho a la Educación. Revista IIDH: Instituto Interamericano de Derechos Humanos, San José, n. 40, p. 341-388, jul./dez., 2004.

TORRES, Ricardo Lobo. Direitos Humanos e a Tributação - Imunidades e Isonomia. Rio de Janeiro: Renovar, 1995.

UNESCO. Clasificación Internacional Normalizada de Ensino. Paris: UNESCO, 2006. Disponível em: http://www.uis.unesco.org/TEMPLATE/pdf/isced/ISCED_E.pdf. Acesso em 23 de janeiro de 2010.

WINTER, Luis Alexandre Carta. "A História do Presidencialismo nos Países do MERCOSUL”. In: GOMES, Eduardo Biacchi; REIS, Tarcisio Hardman (org.). A Integração Regional no Direito Internacional - o Futuro do MERCOSUL e da União Européia. São Paulo: Lex Editora, 2006, p. 51-100.

ZANZUCCHI, Marco Tullio. Instituzioni di Diritto Pubblico secondo la Nuova Constituzione. $8^{\text {a }}$ ed. rev. Milano: Dott. A. Giuffrè, 1948.

\section{NORMATIVA}

Reforçamos que aqui se encontram colacionadas apenas as normas internacionais principais, sendo que as demais permanecem no corpo do texto por atenderem apenas um interesse específico e marginal da dissertação. Além disso, esclarecemos que todos os acessos 
foram verificados em 23 de janeiro de 2010, de modo que nos abstivemos de repetir esse cuidado em todas as referências normativas a seguir:

ALALC. Associação Latino-Americana de Livre comércio. Tratado de Montevidéu de 1960. Montevidéu, Argentina, 1960. Disponível em:

<http://www6.senado.gov.br/legislacao/ListaTextoIntegral.action?id=87146>

ALADI. Associação Latino-Americana de Desenvolvimento Integrado. Tratado de Montevidéu de 1980. Montevidéu, Argentina, 1980. Disponível em: http://www.aladi.org/nsfweb/MenuPagsInternasP/MarcosBuscador.htm

MERCOSUL. Tratado de Assunção de 1991. Assunção, Argentina, 1991. Disponível em: <http://www.mercosur.int/msweb/portal\%20intermediario/pt/index.htm>

. Conselho Mercado Comum. Decisão no $07 / 91$ - Reunião de Ministros da Educação. Brasília, Brasil, 1991. Disponível em:

< http://www.mercosur.int/msweb/portal\%20intermediario/pt/index.htm>

. Setor Educacional do MERCOSUL. Plano Trienal para o Setor Educação no Contexto do MERCOSUL (1992-1994). Las Lenas, Argentina, 1992. Disponível em: < http://www.mercosur.int/msweb/portal\%20intermediario/pt/index.htm>

. Tratado de Ouro Preto de 1994. Ouro Preto, Minas Gerais, 1994. Disponível em: <http://www.mercosur.int/msweb/portal\%20intermediario/pt/index.htm>

Reunião dos Ministros de Educação. Ata nº 06/94 - Ata da VII Reunião de Ministros de Educação dos Países Signatários do Mercado Comum do Sul. Ouro Preto, Brasil, 1994. Disponível em:

$<$ http://www.sic.inep.gov.br/index.php?option=com_docman\&task=cat_view\&gid=48\&dir=E SC\&order=date $\&$ Itemid=32\&limit=10\&limitstart=40>

Conselho Mercado Comum. Decisão no 25/97 - Prorroga a Vigência do Plano Trienal para o Setor Educacional do MERCOSUL. Montevidéu, Argentina, 1997. Disponível em: 
http://www.mercosur.int/msweb/portal\%20intermediario/pt/index.htm.

Setor Educacional do MERCOSUL. Plano Trienal do Setor Educacional do

MERCOSUL (1998-2000). Buenos Aires, Argentina, 1998. Disponível em: $<$ http://www.sic.inep.gov.br/index.php?option=com_docman\&task=cat_view\&gid=27\&Ited= $32 \&$ lang $=$ br $>$

Protocolo de Ushuaia sobre Compromisso Democrático no MERCOSUL, Bolívia e Chile. Ushuaia, Argentina, 1998. Disponível em:

<http://www.mercosur.int/msweb/portal\%20intermediario/pt/index.htm>

Setor Educacional do MERCOSUL. Plano do Setor Educacional do MERCOSUL (2001-2005). Buenos Aires, Argentina, 2001. Disponível em: $<$ http://www.sic.inep.gov.br/index.php?option=com_docman\&task=cat_view\&gid=27\&Itemi $\mathrm{d}=32 \&$ lang $=$ br $>$

- Conselho Mercado Comum. Decisão $n^{\circ}$ 33/04 - FUNDO DE FINANCIAMENTO DO SETOR EDUCACIONAL DO MERCOSUL (FEM). Belo Horizonte, Minas Gerais, 2004. Disponível em:

<http://www.mercosur.int/msweb/portal\%20intermediario/pt/index.htm>

. Conselho Mercado Comum. Protocolo de Adesão da República Bolivariana da Venezuela ao MERCOSUL. Caracas, Venezuela, 2006. Disponível em: <http://www.mercosur.int/msweb/portal\%20intermediario/pt/index.htm> Setor Educacional do MERCOSUL. Plano do Setor Educacional do MERCOSUL (2006-2010). Buenos Aires, Argentina, 2006. Disponível em: < http://www.sic.inep.gov.br/index.php?option=com_docman\&task=cat_view\&gid=27\&Itemid $=32 \&$ lang $=$ br $>$

ORGANIZAÇÃO DAS NAÇOES UNIDAS. Declaração Universal dos Direitos Humanos. Nova Iorque, 1948. Disponível em:

http://www.onu-brasil.org.br/documentos_direitoshumanos.php. 
Pacto Internacional de Direitos Econômicos, Sociais e Culturais. Nova

Iorque, 1966. Disponível em: http://www.un.org/millennium/law/iv-3.htm.

Convenção sobre o Direito dos Tratados. Viena, 1969. Apud DALLARI,

Pedro B. A. Constituições e os Tratados Internacionais. São Paulo: Saraiva, 2003.

. Convenção sobre os Direitos da Criança. Nova Iorque, 1989. Disponível em: http://www.onu-brasil.org.br/doc_crianca.php.

ORGANIZAÇÃO DOS ESTADOS AMERICANOS. Declaração Americana dos Direitos e Deveres do Homem. Bogotá, 1948. Disponível em:

http://www.direitoshumanos.usp.br/index.php/OEA-Organiza\%C3\%A7\%C3\%A3o-dos-

Estados-Americanos/declaracao-americana-dos-direitos-e-deveres-do-homem.html

Protocolo Adicional à Convenção Americana sobre os Direitos Humanos em Matéria de Direitos Econômicos, Sociais e Culturais. San Salvador, 1988. Apud BRASIL. Decreto n.678, publicado em 06.11.1992. Disponível em:

http://www.planalto.gov.br/ccivil_03/decreto/D0678.htm.

PARAGUAI. Constituição 1844. Disponível em: http://www.tsje.gov.py/constituciones.php.

UNESCO. Declaração Mundial sobre a Educação para Todos: Satisfação das Necessidades Básicas de Aprendizagem. Jomtien, 1990.

URUGUAI. Constituição 1830. Disponível em:

http://www.parlamento.gub.uy/Constituciones/Const830.htm 


\begin{abstract}
ANEXO
Equivalência dos anos de escolaridade na Educação Básica
\end{abstract}

nos Estados-Membros do MERCOSUL, para fins de reconhecimento de diploma e graus, conforme aprovado pela Decisão CMC 06/06.

\begin{tabular}{|c|c|c|c|c|c|}
\hline \multicolumn{2}{|l|}{ ARGENTINA } & \multirow{2}{*}{$\begin{array}{l}\text { BRASIL } \\
\text { 1 Série } \\
\end{array}$} & \multicolumn{2}{|c|}{ PARAGUAI } & URUGUAI \\
\hline 1ํGrau de Primária & $1^{\circ} \mathrm{EGB}$ & & $1^{\circ} \mathrm{EEB}$ & 1ํPrimária & 1ํ Primária \\
\hline \multicolumn{2}{|l|}{6 anos } & 6 anos & \multicolumn{2}{|c|}{6 anos } & 6 anos \\
\hline 2ํㅡrau de Primária & $2^{\circ} \mathrm{EGB}$ & $2^{\circ}$ Série & $2^{\circ}$ EEB & $2^{0}$ Primária & $2^{0}$ Primária \\
\hline \multicolumn{2}{|l|}{7 anos } & 7 anos & \multicolumn{2}{|c|}{7 anos } & 7 anos \\
\hline 3 Grau de Primária & $3 \circ \mathrm{EGB}$ & 3 Série & $3^{\circ}$ EEB & $3^{\circ}$ Primária & 3ํㅜrimária \\
\hline \multicolumn{2}{|l|}{8 anos } & 8 anos & \multicolumn{2}{|c|}{8 anos } & 8 anos \\
\hline 4 Grau de Primária & $4^{\circ} \mathrm{EGB}$ & 4ํㅗㄹie & $4^{\circ} \mathrm{EEB}$ & 4 Primária & 4 Primária \\
\hline \multicolumn{2}{|l|}{9 anos } & 9 anos & \multicolumn{2}{|c|}{9 anos } & 9 anos \\
\hline 5o Grau de Primária & $5^{\circ} \mathrm{EGB}$ & 5 Série & $5^{\circ} \mathrm{EEB}$ & $5^{\circ}$ Primária & 5 Primária \\
\hline \multicolumn{2}{|l|}{10 anos } & 10 anos & \multicolumn{2}{|c|}{10 anos } & 10 anos \\
\hline 6 Grau de Primária & 6 $\mathrm{EGB}$ & 6을ie & $6^{\circ} \mathrm{EEB}$ & 60 Primária & 60 Primária \\
\hline \multicolumn{2}{|l|}{11 anos } & 11 anos & \multicolumn{2}{|c|}{11 anos } & 11 anos \\
\hline 7ํㅡau de Primária & $7^{\circ} \mathrm{EGB}$ & 7오́ie & $7^{\circ} \mathrm{EEB}$ & 1ํ Ciclo Básico & 1ํCiclo Básico \\
\hline \multicolumn{2}{|l|}{12 anos } & 12 anos & \multicolumn{2}{|c|}{12 anos } & 12 anos \\
\hline 1ํAno de Secundária & 8 EGB & 8 Série & 8 EEB & 2o Ciclo Básico & 2ํㅜclo Básico \\
\hline \multicolumn{2}{|l|}{13 anos } & 13 anos & \multicolumn{2}{|c|}{13 anos } & 13 anos \\
\hline 2ํAno de Secundária & 9 $\mathrm{EGB}$ & 9 Série & 9ํㅡㄹ & 3 Ciclo Básico & 3 Ciclo Básico \\
\hline \multicolumn{2}{|l|}{14 anos } & 14 anos & \multicolumn{2}{|c|}{14 anos } & 14 anos \\
\hline 3ํAno de Secundária & $\begin{array}{c}10 \\
\text { Polimodal }\end{array}$ & $1^{\circ}$ Ano & 1ํMédio & $\begin{array}{c}4^{\circ} \text { Ciclo } \\
\text { Bacharelado }\end{array}$ & $\begin{array}{c}1^{\circ} \text { Bacharelado } \\
\text { Diversificado }\end{array}$ \\
\hline \multicolumn{2}{|l|}{15 anos } & 15 anos & \multicolumn{2}{|c|}{15 anos } & 15 anos \\
\hline $4^{\circ}$ Ano de Secundária & $\begin{array}{c}2^{\circ} \\
\text { Polimodal } \\
\end{array}$ & $2^{\circ}$ Ano & 2º Médio & $\begin{array}{c}5^{\circ} \text { Ciclo } \\
\text { Bacharelado } \\
\end{array}$ & $\begin{array}{c}2^{\circ} \text { Bacharelado } \\
\text { Diversificado }\end{array}$ \\
\hline \multicolumn{2}{|l|}{16 anos } & 16 anos & \multicolumn{2}{|c|}{16 anos } & 16 anos \\
\hline 5 Ano de Secundária & $\begin{array}{c}3^{\circ} \\
\text { Polimodal }\end{array}$ & 3o Ano & 3ํMédio & $\begin{array}{c}6^{\circ} \text { Ciclo } \\
\text { Bacharelado }\end{array}$ & $\begin{array}{c}\text { 30 Bacharelado } \\
\text { Diversificado }\end{array}$ \\
\hline \multicolumn{2}{|l|}{17 anos } & 17 anos & \multicolumn{2}{|c|}{17 anos } & 17 anos \\
\hline
\end{tabular}


